Florida International University

FIU Digital Commons

FIU Electronic Theses and Dissertations

University Graduate School

$11-15-2013$

\title{
Development of an Enhanced Hydro-geochemical Model to Address Mercury-speciation Fate and Transport in Aquatic Environments
}

Nantaporn Noosai

Florida International University, nnoos001@fiu.edu

DOI: $10.25148 /$ etd.FI14040822

Follow this and additional works at: https:// digitalcommons.fiu.edu/etd

Part of the Computational Engineering Commons, and the Environmental Engineering Commons

\section{Recommended Citation}

Noosai, Nantaporn, "Development of an Enhanced Hydro-geochemical Model to Address Mercury-speciation Fate and Transport in Aquatic Environments" (2013). FIU Electronic Theses and Dissertations. 1143.

https://digitalcommons.fiu.edu/etd/1143 


\section{FLORIDA INTERNATIONAL UNIVERSITY}

Miami, Florida

DEVELOPMENT OF AN ENHANCED HYDRO-GEOCHEMICAL MODEL TO ADDRESS MERCURY-SPECIATION FATE AND TRANSPORT IN AQUATIC ENVIRONMENTS

A dissertation submitted in partial fulfillment of the requirements for the degree of DOCTOR OF PHILOSOPHY

in

CIVIL ENGINEERING

by

Nantaporn Noosai

2014 
To: Dean Amir Mirmiran

College of Engineering and Computing

This dissertation, written by Nantaporn Noosai, and entitled Development of an Enhanced Hydro-geochemical Model to Address Mercury-speciation Fate and Transport in Aquatic Environments, having been approved in respect to style and intellectual content, is referred to you for judgment.

We have read this dissertation and recommend that it be approved.

$\begin{array}{r}\hline \text { Yong Cai } \\ \hline \text { Georgio Tachiev } \\ \hline \text { Walter Z. Tang } \\ \hline \text { Lakshmi N. Reddi } \\ \hline \text { Hector R. Fuentes, Major Professor }\end{array}$

Date of Defense: November 15, 2013

The dissertation of Nantaporn Noosai is approved.

Dean Amir Mirmiran

College of Engineering and Computing

Dean Lakshmi N. Reddi

University Graduate School

Florida International University, 2014 
(C) Copyright 2014 by Nantaporn Noosai

All rights reserved. 


\section{DEDICATION}

I dedicate this dissertation to my wonderful family, especially my parents, my grandmother, and my brother for encouraging me to pursue my dreams and supporting me in every way for all these years. Thank you for all of your love, patience and sacrifice. 


\section{ACKNOWLEDGMENTS}

I would like to express my earnest gratitude, through this acknowledgement, to many generous and inspiring people in my life who have been extremely supportive and encouraging throughout my doctoral studies:

To my advisor, Dr. Hector R. Fuentes, for his invaluable advice, vision, and encouragement during my doctoral program. I am very thankful for his guidance and inspiration.

To Dr. Georgio Tachiev for his guidance, kindness, and support for completing this dissertation. I highly appreciate the contribution of Dr. Lakshmi N. Reddi, Dr. Walter Z. Tang, and Dr. Yong Cai. I am very thankful for their valuable time and input on my work.

To Haydee, Laura and all administrative staff in the Civil and Environmental Engineering Department as well as the Dean's office for their friendly help and support.

A special thanks to Dr. Khokiat Kengskool for his support, encouragement, inspiration, and kindness. He helped me to be strong and persistent to accomplish my goal. I would like to express my sincere thanks to my friends Vivek and Maria for their friendship and assistance. I would like to thank family and my husband, Vineeth, who inspired me in pursuing my Ph.D. His continued support and inspiration helped me in achieving my goal.

I am grateful to the Department of Civil and Environmental Engineering and Applied Research Center of Florida International University for the financial support they provided during my doctorate study. 
A special mention goes to my late committee member Prof. Fang Zhao. She is greatly missed and I am very thankful to her for all the help she provided me during my academic days in FIU. 


\section{ABSTRACT OF THE DISSERTATION \\ DEVELOPMENT OF AN ENHANCED HYDRO-GEOCHEMICAL MODEL TO \\ ADDRESS MERCURY-SPECIATION FATE AND TRANSPORT IN AQUATIC \\ ENVIRONMENTS \\ by \\ Nantaporn Noosai}

Florida International University, 2014

Miami, Florida

Professor Hector R. Fuentes, Major Professor

An awareness of mercury $(\mathrm{Hg})$ contamination in various aquatic environments around the world has increased over the past decade, mostly due to its ability to concentrate in the biota. Because the presence and distribution of $\mathrm{Hg}$ in aquatic systems depend on many factors (e.g., pe, $\mathrm{pH}$, salinity, temperature, organic and inorganic ligands, sorbents, etc.), it is crucial to understand its fate and transport in the presence of complexing constituents and natural sorbents, under those different factors. An improved understanding of the subject will support the selection of monitoring, remediation, and restoration technologies.

The coupling of equilibrium chemical reactions with transport processes in the model PHREEQC offers an advantage in simulating and predicting the fate and transport of aqueous chemical species of interest. Thus, a great variety of reactive transport problems could be addressed in aquatic systems with boundary conditions of specific interest. Nevertheless, PHREEQC lacks a comprehensive thermodynamic database for $\mathrm{Hg}$. Therefore, in order to use PHREEQC to address the fate and transport of $\mathrm{Hg}$ in 
aquatic environments, it is necessary to expand its thermodynamic database, confirm it and then evaluate it in applications where potential exists for its calibration and continued validation.

The objectives of this study were twofold: 1) to develop, expand, and confirm the Hg database of the hydrogeochemical PHREEQC to enhance its capability to simulate the fate of $\mathrm{Hg}$ species in the presence of complexing constituents and natural sorbents under different conditions of $\mathrm{pH}$, redox, salinity and temperature; and 2) to apply and evaluate the new database in flow and transport scenarios, at two field test beds: Oak Ridge Reservation, Oak Ridge, TN and Everglades National Park, FL, where Hg is present and is of much concern.

Overall, this research enhanced the capability of the PHREEQC model to simulate the coupling of the $\mathrm{Hg}$ reactions in transport conditions. It also demonstrated its usefulness when applied to field situations. 
I. INTRODUCTION AND LITERATURE REVIEW ……….................................. 1

1.1 Background and Literature Review …………….............................................. 1

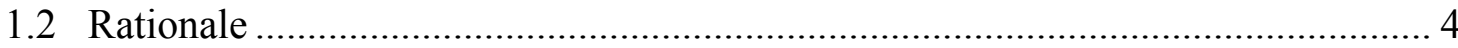

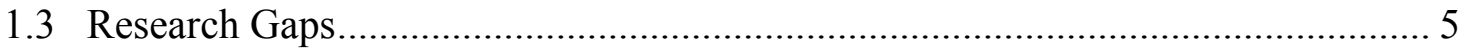

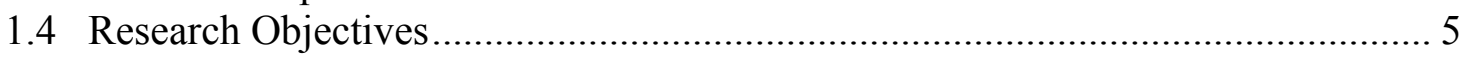

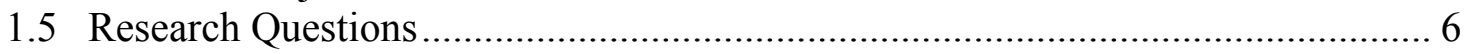

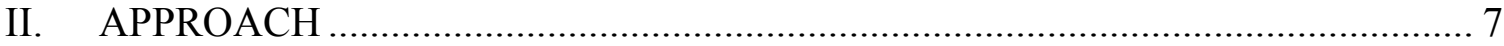

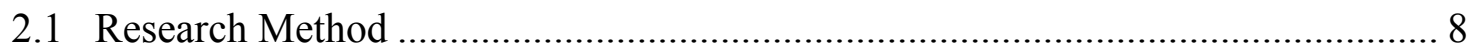

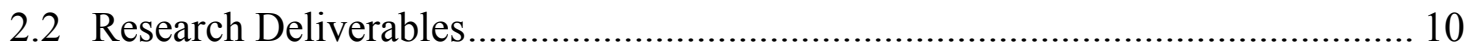

III. MODEL BACKGROUND AND THEORY ………............................................. 11

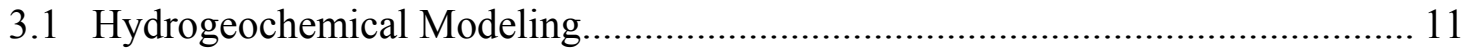

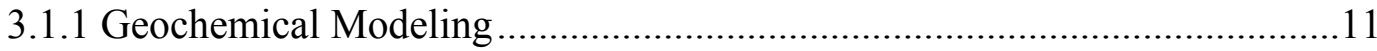

3.1.2 Flow and Transport ..............................................................................13

3.2 PHREEQC and PHAST Governing Equations ................................................. 15

3.2.1 Activity and Mass-Action Equations .........................................................15

3.2.2 Transport Equations for Ground and Surface Water ...................................21

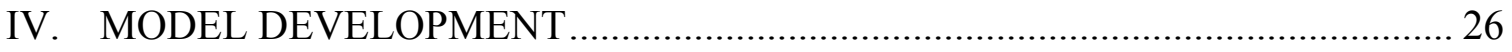

4.1 Enhanced Model Database Input Method....................................................... 26

4.1.1 Hg Dissolution and Precipitation..........................................................26

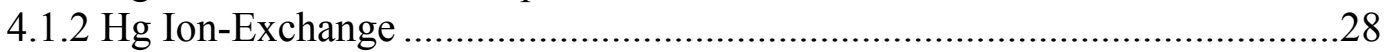

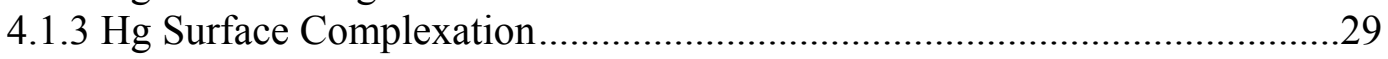

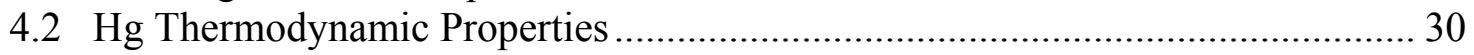

4.2.1 Hg Reaction Equilibrium and Solubility Constants .....................................30

4.2.2 Hg-DOM Reaction Equilibrium Constants...................................................35

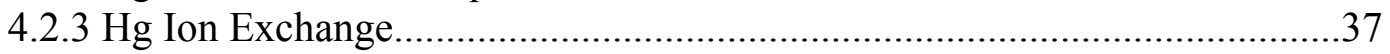

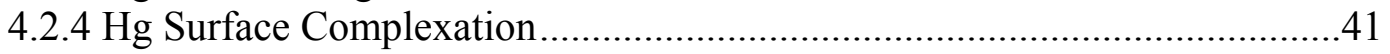

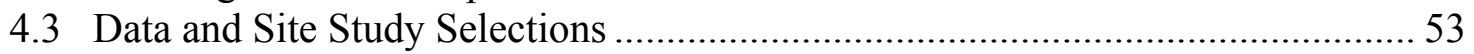

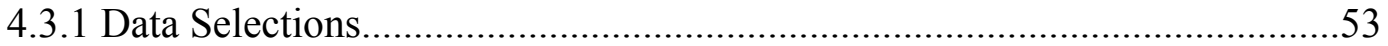

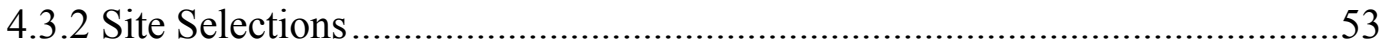

4.4 Model Confirmation in Batch Mode - Lab Scale ............................................... 58

4.4.1 Testing Scenario 1: $\quad \mathrm{Hg}-\mathrm{CH}_{3} \mathrm{COOH}$ (1 nmole: 0.33 mmole)

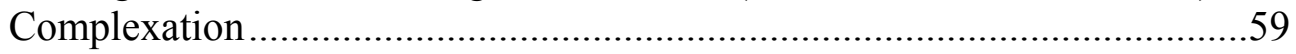

4.4.2 Testing Scenario 2: $\quad \mathrm{Hg}-\mathrm{CH}_{3} \mathrm{COOH}$ (1 nmole: 3.3 mmole)

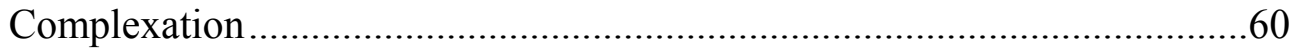

4.4.3 Testing Scenario 3: $\mathrm{Hg}-\mathrm{CH}_{3} \mathrm{COOH}$ (1 nmole: 33 mmole) Complexation ...62

4.4.4 Testing Scenario 4: MeHg complexation ...................................................63

4.5 Process Confirmation in Batch Mode - Lab Scale ............................................... 64

4.5.1 Testing Scenario 1: $\mathrm{Hg}(\mathrm{II})$ Surface Complexation on $\mathrm{Fe}(\mathrm{OH})_{3} \ldots \ldots \ldots \ldots \ldots \ldots \ldots . . .64$ 
4.5.2 Testing Scenario 2: $\mathrm{Hg}(\mathrm{II})$ Sorption on Humic Acid.

4.5.3 Testing Scenario 3: $\mathrm{Hg}$ and $\mathrm{MeHg}$ Sorption Kinetic on Floridan Aquifer Bedrocks

4.6 Mathematical Model Confirmation in Batch Mode - Field Scale ....................... 72

4.6.1 Testing Scenario 1: Model Prediction Capability for Major Ions at Wide

Range of Ionic Strength (Increase in Salinity).

4.7 Process Confirmation in Transport Mode - Field Scale.

4.7.1 Testing Scenario 1: Testing the Fate and Transport of $\mathrm{Hg}$ and Heavy Metals in a Groundwater Setting at Oak Ridge, TN.

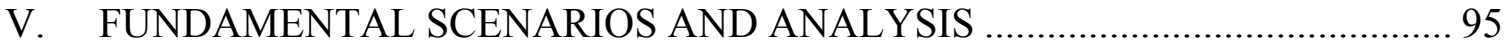

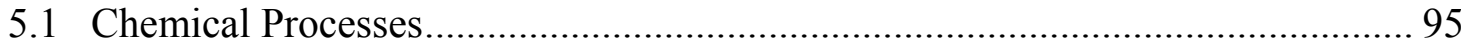

5.1.1 Species, Solubility, and Precipitation Processes........................................95

5.1.2 Ion Exchange Process .........................................................................99

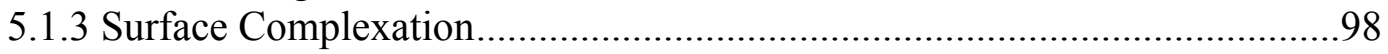

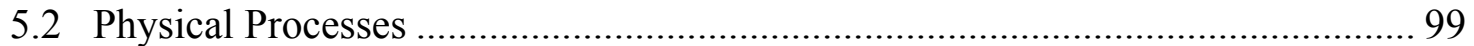

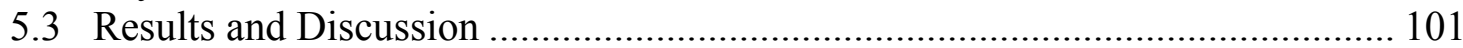

5.3.1 Chemical Processes: Batch Mode .........................................................102

5.3.2 Chemical and Physical Processes: Transport Mode ................................117

VI. MODEL APPLICATIONS, RESULTS AND DISCUSSION …........................ 136

6.1 ORR Test-Bed Simulations - Batch Mode ........................................................ 136

6.1.1 Hg Speciation Distribution ................................................................. 138

6.1.2 Sensitivity Analysis of $\mathrm{Hg}$ Species to Water Temperature and $\mathrm{pH}$............138

6.1.3 Sensitivity Analysis of Mineral Saturation Index to Water Temperature and $\mathrm{pH}$

6.2 ORR Test-Bed Simulation - Groundwater Transport Mode ............................. 142

6.2.1 Hg in Groundwater Transport: Bear Creek Valley ....................................142

6.3 ORR Test-Bed Simulation - Surface Water Transport Mode .......................... 149

6.3.1 Hg in Surface Water Transport: Hg Reduction Load to EFPC...................151

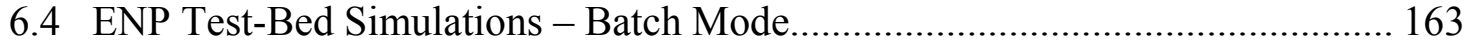

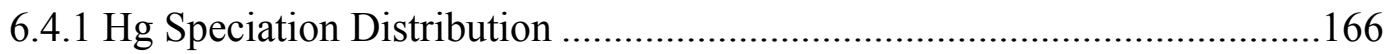

6.4.2 Sensitivity Analysis of $\mathrm{Hg}$ Species to Water Temperature and $\mathrm{pH}$............166

6.4.3 Sensitivity Analysis of Mineral Saturation Index to Water Temperature

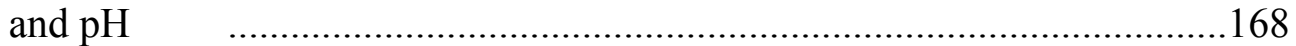

6.4.4 Sensitivity to Salinity on Inorganic Hg Speciation.................................169

6.4.5 Hg-S Complexation and the Production of MeHg.................................173

6.5 ENP Test-Bed Simulation - Surface Water Transport Mode........................... 180

VII. CONCLUSIONS........................................................................................... 193

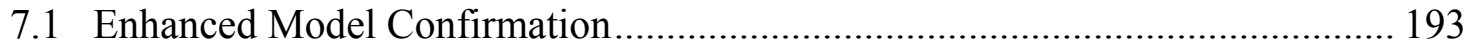

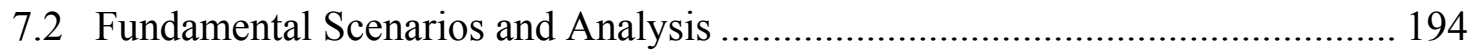

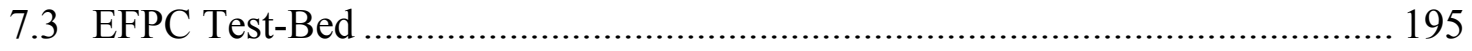

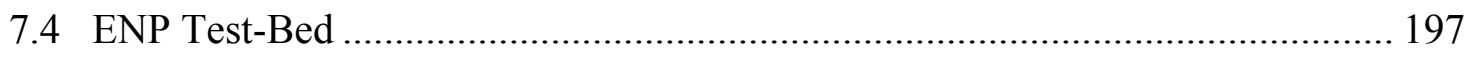


VIII. RECOMMENDATION FOR FURTHER STUDY ........................................ 199

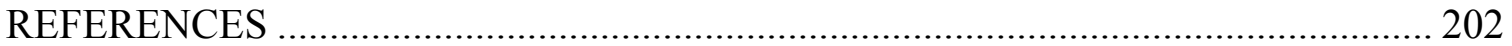

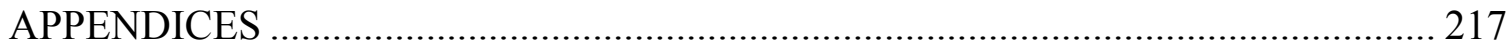

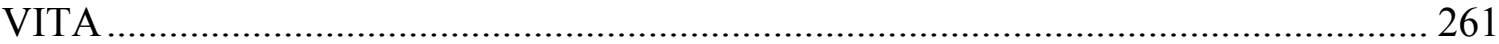




\section{LIST OF TABLES}

TABLE

PAGE

1 The main features and capabilities of available hydrogeochemical models......... 14

2 The reaction equilibrium constants of $\mathrm{Hg}$ available in PHREEQC (Parkhurst and Appelo, 1999).

3 Hg solubility reaction equilibrium constants available in PHREEQC (Parkhurst and Appelo, 1999).

4 Thermodynamic propertied of $\mathrm{Hg}$-Acetate obtained from Gårdfeldt et al. (2003)

5 Hg reaction equilibrium and solubility constants (Gårdfeldt et al., 2001)..... 34

6 Reaction equilibrium constants of $\mathrm{Hg}$ and reactive functional groups in DOM [thiol group $\left(\mathrm{RS}^{-}\right)$, oxygen- or nitrogen-containing functional group ( $\mathrm{RO}^{-}$and $\left.\mathrm{RN}^{-}\right)$]

7 CEC of common soil and sediment materials (Appelo and Postma, 2005;

Bergaya and Vayer, 1997)

8 PHREEQC existing database of ion exchange coefficients relative to $\mathrm{Na}^{+}$ (Appelo and Postma, 2005; Bruggenwert and Kamphorst, 1979; Parkhurst and Appelo, 1999)

9 Ion exchange coefficients for various ions related to $\mathrm{Hg}(\mathrm{II})$ (Khan and Alam, 2004)

10 Dzombak and Morel (1990)'s sorption-reaction constant database for $\mathrm{Hg}$.

11 Surface property of iron oxide minerals (Arias et al., 2004; Miretzky et al., 2005; Martell and Smith, 2001).....

12 Quartz and gibbsite properties used in Sarkar et al. (1999). 43

13 The surface complexation and the intrinsic equilibrium constants ( $\log \mathrm{K}_{\mathrm{int}}$ ) of $\mathrm{Hg}(\mathrm{II})$ adsorption on quartz (三Sio) (Sarkar et al., 1999)

14 The surface complexation and the intrinsic equilibrium constants ( $\left.\log \mathrm{K}_{\text {int }}\right)$ of $\mathrm{Hg}(\mathrm{II})$ adsorption on gibbsite (三Aloh) (Sarkar et al., 1999)

15 Kaolinite properties used in Sarkar et al. (2000) 
16 The characteristic of the model sorbents and Langmuir Isotherm for $\mathrm{Hg}(\mathrm{II})$ sorptions Cruz-Guzman et al. (2003).

17 Langmuir parameters for $\mathrm{Hg}$ (II) sorption isotherm on Goethite, Hydrous Manganese Oxides, and Birnessite in freshwater (0\%o salinity, Liang et al., 2013)

18 Langmuir parameters for $\mathrm{Hg}(\mathrm{II})$ sorption isotherm on Goethite, Hydrous Manganese Oxides, and Birnessite in seawater (33\%o salinity, Liang et al., 2013)

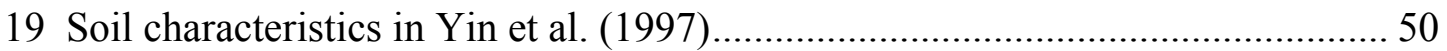

20 The kinetic sorption parameters of $\mathrm{Hg}(\mathrm{II})$ on different soils (Yin et al., 1997).... 51

21 Sorption kinetic parameters for the $\mathrm{Hg}$ and $\mathrm{MeHg}$ on the Floridan aquifer bedrocks (Krabbenhoft et al., 2007) 52

22 Equilibrium binding constants (Drexel et al., 2002). 52

23 Scenario 1 water condition in the Gårdfeldt et al. (2003) study used for model confirmation

24 Scenario 2: water condition in the Gårdfeldt et al. (2003) study used for model confirmation

25 Scenario 3: water condition in the Gårdfeldt et al. (2003) study used for model confirmation

26 Scenario 4: water condition in Gårdfeldt et al. (2001) study used for model validation for $\mathrm{MeHg}$ complexation.

27 Scenario 1: sorption experimental condition in the Cruz-Guzman et al. (2003) study used for model confirmation for $\mathrm{Hg}(\mathrm{II})$ surface complexation on $\mathrm{Fe}(\mathrm{OH})_{3}$

28 Scenario 2: sorption experimental condition in the Cruz-Guzman et al. (2003) study used for model confirmation for $\mathrm{Hg}$ (II) sorption of Humic Acid 66

29 Scenario 3: water condition used to test the model capability for $\mathrm{Hg}$ and $\mathrm{MeHg}$ kinetic sorption on Floridan aquifer bedrock (Krabbenhoft et al., 2007).. 68

30 Scenario 3: Comparison results of $\mathrm{Hg}$ kinetic sorption on Floridan aquifer bedrock between Krabbenhoft et al. (2007) study and kinetic model calculation 
31 Scenario 3: Comparison results of $\mathrm{MeHg}$ kinetic sorption on Floridan aquifer bedrock between Krabbenhoft et al. (2007) study and kinetic model calculation....

32 The location of the selected freshwater water quality monitoring stations (DBHYDRO)

33 Freshwater water quality used for the fresh-seawater mixing model, unit in $\mathrm{mg} / \mathrm{L}$ for major ion and ${ }^{\circ} \mathrm{C}$ for temperature (DBHYDRO) 73

34 Seawater water quality used for the fresh-seawater mixing model (DBHYDRO) 74

35 Analysis of groundwater at core hole GW-135, Oak Ridge, TN (Dreier et al., 1993)

36 Exchange reaction equations and coefficients for $\mathrm{Ca}$ and $\mathrm{Mg}$ (Appelo and Postma, 2005; Bruggenwert and Kamphorst, 1979; and Stumm and Morgan, 1996)

37 Equations and constants of sorption reactions of ions on $\mathrm{Fe}(\mathrm{OH}) 3$ (Farley et al., 1984; Stumm and Morgan, 1996; and Dzombak and Morel, 1990)

38 Predicted and measured groundwater quality between core holes GW-135 and GW-131, Oak Ridge, TN (concentrations in mg/L)

39 Water quality data obtained from groundwater well 135 located in ORR area (Dreier et al., 1993; Elvado Environmental LLC, 2009 and 2011)....

40 Water quality data used for $\mathrm{Hg}$ fate and transport simulations (Dreier et al., 1993; Elvado Environmental LLC, 2009 and 2011).

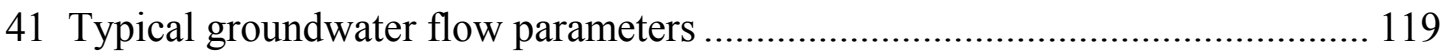

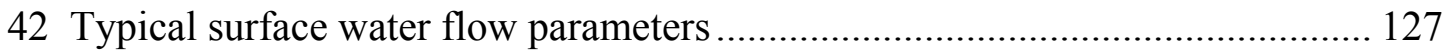

43 Conditions used for sensitivity analysis of dispersion to exchange reaction between $\mathrm{Hg}$ and Vermiculite

44 EFPC water quality data (Dong et al., 2010)

45 Water quality data used for Hg transport study in Bear Creek Valley (Elvado Environmental LLC, 2009 and 2011)....

46 Groundwater flow parameters used for $\mathrm{Hg}$ transport in Bear Creek Valley simulations (Jago et al., 1995; Kelkar et al., 2006). 
47 Optimum amount of sorbents at GW-363 and GW-639

48 EFPC surface water quality at different monitoring stations (ion concentrations in mg/L) (Loar et al., 2011; Dong et al., 2010; Brooks and Southworth, 2011).

49 Transport parameters used for $\mathrm{Hg}$ transport study in EFPC

50 ENP surface water quality data at P33 station (during 2001-2011) (mg/L for concentration, ${ }^{\circ} \mathrm{C}$ for temperature) (DBHYDRO).... 165

51 Seawater data (temperature in ${ }^{\circ} \mathrm{C}$, ion concentration in $\left.\mathrm{mg} / \mathrm{L}\right)(\mathrm{DBHYDRO}) \ldots 170$

52 Water quality data at ENP monitoring stations shown in Figure 70 (DBHYDRO) 175

53 Water quality data at different stations used for the $\mathrm{Hg}$ transport study (DBHYDRO) 181

54 Transport parameters used for Hg transport study in Shark River Slough 182 


\section{LIST OF FIGURES}

FIGURE

PAGE

1 Gårdfeldt et al. (2003) study of mercuric acetate complexes over a wide pH...... 33

2 MeHg species as function of $\mathrm{pH}$; Gårdfeldt et al. (2001) .................................... 35

$3 \mathrm{Hg}$ (II) sorption isotherm on single model sorbent (Cruz-Guzman et al., 2003)... 47

$4 \mathrm{Hg}$ (II) sorption isotherms on binary (a), (b) and (c) and ternary (d) model sorbents (Cruz-Guzman et al., 2003) ............................................................. 47

5 Oak Ridge Reservation Map (modified after www.esd.ornl.gov) ....................... 55

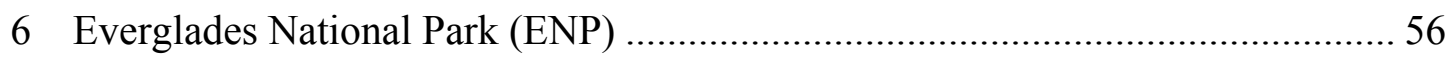

7 Model speciation prediction capability testing; scenario $1(\mathrm{Hg}: \mathrm{CH} 3 \mathrm{COOH}=$ $1 \mathrm{nmol}: 0.33 \mathrm{mmol}$ ) result obtained from Gårdfeldt et al. (2003) (a) and

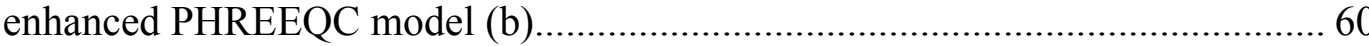

8 Model speciation prediction capability testing; the scenario 2 ( $\mathrm{Hg}$ : $\mathrm{CH} 3 \mathrm{COOH}=1 \mathrm{nmol}: 3.3 \mathrm{mmol}$ ) result obtained from Gårdfeldt et al. (2003) (a) and enhanced PHREEQC model (b).

9 Model speciation prediction capability testing; the scenario $2(\mathrm{Hg}$ : $\mathrm{CH} 3 \mathrm{COOH}=1 \mathrm{nmol}: 33 \mathrm{mmol}$ ) result obtained from Gårdfeldt et al. (2003) (a) and enhanced PHREEQC model (b)

10 Model speciation prediction capability testing; the scenario $4 \mathrm{MeHg}$ complexation result obtained from Gårdfeldt et al. (2001) (a) and enhanced PHREEQC model (b).

11 The model surface complexation prediction capability testing for scenario 1: $\mathrm{Hg}(\mathrm{II})$ surface complexation on $\mathrm{Fe}(\mathrm{OH}) 3$, sorption experimental result CruzGuzman et al. (2003) (dot); the enhanced PHREEQC model (dashed line).

12 The model Hg-HA complexation prediction capability testing for scenario 2: sorption experimental result Cruz-Guzman et al. (2003) (dot); enhanced PHREEQC model (dashed line).

13 The model kinetic sorption prediction capability testing for scenario 3 : $\mathrm{Hg}$ and $\mathrm{MeHg}$ kinetic sorption on Floridan aquifer bedrock experimental result Krabbenhoft et al. (2007) (dot); enhanced PHREEQC model (dashed line). 
14 Comparison of major ion concentrations as a function of salinity in the mixtures between observed data collected from DBHYDRO (dots) and model results (lines); (a) $\mathrm{Na}$, (b) $\mathrm{Mg}$, (c) $\mathrm{K}$, (d) $\mathrm{Ca}$, (e) $\mathrm{Cl}$ and (f) $\mathrm{SO} 4$.

15 Water $\mathrm{pH}$ in the Floridan aquifer (open circles) for the sample collected during 2005 and 2006. The theoretical water $\mathrm{pH}$ (solid line) was calculated by PHREEQC model

16 Various minerals saturation indexes (a) Calcite; (b) Aragonite; (c) Dolomite; (d) Magnesite; (e) Gypsum; (f) Halite, observed data (dots) and model result (lines)

17 Study area location of the five core holes and of the section A-A between GW-131 and GW-135 at Y-12 plant, Oak Ridge, Tennessee (Dreier et al., 1993)

18 Profile, is strike-parallel section, shows hydrology and geology for core holes GW-131 and GW-135 where $€ d$ is Copper Ridge Dolomite, $€ m$ is Maynardville Limestone, and $€ \mathrm{n}$ is Nolichucky Shale (obtained from Dreier et al., 1991; and Toran and Saunde, 1999)

19 Effect of ion exchange on metal concentration along the distance between core holes

20 Effect of ion exchange and sorption on dissolved metal concentration along the distance between core holes

21 Dissolved metal concentrations, (a) $\mathrm{Hg}$; and (b) $\mathrm{Pb}$ and $\mathrm{pH}$ profiles along the distance between core holes: only ion exchange model (dashed line) and ion exchange with sorption on $\mathrm{Fe}(\mathrm{OH}) 3$ (solid line)

22 PHREEQC solution and precipitation process ……………………………….... 96

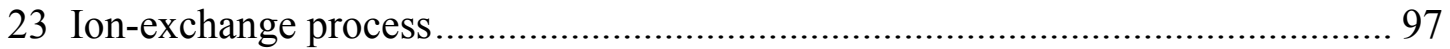

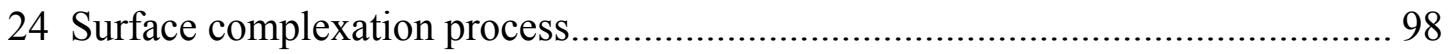

25 Mass conservation for transport process (Parkhurst and Appelo 1999) ............... 99

26 Coupling processes in PHREEQC to transport process calculations .................. 101

$27 \mathrm{pe}-\mathrm{pH}$ diagram of $\mathrm{Hg}$-species at temperature $20{ }^{\circ} \mathrm{C}$.......................................... 104

28 A pe-pH diagram for mercury in a typical soil solution (total $\mathrm{Hg}$ of $5 \times 10^{-11} \mathrm{M}$, $\mathrm{Cl}$ of $2 \times 10^{-4} \mathrm{M}$ and $\mathrm{S}$ of $6 \times 10^{-4} \mathrm{M}$ ) (Sigel, A. and Sigel, H., 1997)................ 106 
29 Eh-pH diagram for $\mathrm{Hg}$ at $25^{\circ} \mathrm{C}$ and 1 atmosphere pressure. The dashed lines represent the stability field of aqueous species, and solid lines are for solid phases. System includes water containing $36 \mathrm{mg} / \mathrm{L} \mathrm{Cl}$, total S $96 \mathrm{mg} / \mathrm{L}$ as $\mathrm{SO}_{4}{ }^{2-}$ (Little, M.E., 2006). On axis y, pe ranges from -13.5 to 20 (Eh to pe conversion is calculated using Eh-pe relationship: Eh $(\mathrm{mV})=59.2$ pe, obtained from Stumm and Morgan, 1996) 106

30 Davis et al., 1997 studied the ability of mercury to cross tissue membranes of the mouth, esophagus, stomach, and the small and large intestines. Figure shows Gastrointestinal tract $\mathrm{pH}$-Eh conditions superimposed on mercury system, $\mathrm{A}=$ Stomach, and $\mathrm{B}=$ Small Intestinal conditions. Activity of $\mathrm{Cl}=$ $10^{-3} \mathrm{M}, \mathrm{S}=10^{-5} \mathrm{M}, \mathrm{Hg}=10^{-5} \mathrm{M}$. On axis y, pe ranges from -16 to 20 (Eh to pe conversion is calculated using Eh-pe relationship: Eh $(\mathrm{mV})=59.2$ pe, obtained from Stumm and Morgan, 1996).

31 Stability diagram for $\mathrm{Hg}$ in the presence of $0.1 \mathrm{M}$ total I and $0.001 \mathrm{M}$ of S (Cox et al., 1996)

32 pe-pH diagram of $\mathrm{Hg}$-species with $\mathrm{Fe}=20 \mathrm{mg} / \mathrm{L}$ and at temperature $20{ }^{\circ} \mathrm{C} \ldots . .109$

33 pe-pH diagram of $\mathrm{Hg}$ mobilization with $\mathrm{Fe}=20 \mathrm{mg} / \mathrm{L}$, temperature $20{ }^{\circ} \mathrm{C} \ldots \ldots . .110$

$34 \mathrm{Hg}$ species sensitivity to temperature $\left(5-35^{\circ} \mathrm{C}\right)$ and $\mathrm{pH}(2-10)$, black box shows groundwater $\mathrm{pH}$ range.

35 Sensitivity of the SI of minerals to water temperature and $\mathrm{pH}$ at oxidation water condition

36 Sensitivity analysis of $\mathrm{Hg}$-species concentration with respect to different exchangers (the effect of ion exchange); $1 \mathrm{~kg} / \mathrm{L}$ of exchangers, temperature 25 ${ }^{\circ} \mathrm{C}$, oxidation condition

37 Sensitivity analysis of $\mathrm{Hg}$-species concentration with respect to different sorbents (the effect of surface complexation) ; $1 \mathrm{~g} / \mathrm{L}$ of sorbents, temperature $25{ }^{\circ} \mathrm{C}$, oxidation condition

38 Model of $\mathrm{Hg}$ transport for a typical groundwater flow condition 120

$39 \mathrm{Hg}$-species flow profile in typical groundwater flow condition 120

40 Model of $\mathrm{Hg}$ transport for a typical groundwater flow condition. Simulations were performed for each individual exchanger (Illite, Montmorillonite and Vermiculite)

41 The effect of ion exchange on $\mathrm{Hg}$-species flow profiles for different exchangers (Illite, Montmorillonite and Vermiculite). The exchangers were individually applied to cells 4 and 5 (40 and $50 \mathrm{~m}$ of flow distance).... 
$42 \mathrm{Model}$ of $\mathrm{Hg}$ transport for a typical groundwater flow condition. Simulations were performed for each individual sorbents $(\mathrm{Fe}(\mathrm{OH}) 3$, Gibbsite and Kaolinite)

43 The effect of surface complexation on $\mathrm{Hg}$-species flow profiles for different sorbents $(\mathrm{Fe}(\mathrm{OH}) 3$, Gibbsite and Kaolinite).The sorbents were applied to cells 4 and 5 (40 and $50 \mathrm{~m}$ of flow distance)

44 Model of $\mathrm{Hg}$ transport for a typical surface water flow condition 128

$45 \mathrm{Hg}$-species flow profile in a typical surface water flow condition 128

46 Model of $\mathrm{Hg}$ transport for a typical surface water flow condition. Simulations were performed for each individual exchanger (Illite, Montmorillonite and Vermiculite)

47 Effect of dispersion on the exchange reaction and $\mathrm{Hg}$ transport for surface water flow condition

48 Model of $\mathrm{Hg}$ transport for a typical surface water flow condition. Simulations were performed for each individual sorbents $(\mathrm{Fe}(\mathrm{OH}) 3$, Gibbsite and Kaolinite)

49 The effect of surface complexation on $\mathrm{Hg}$-species flow profiles for different sorbents $(\mathrm{Fe}(\mathrm{OH}) 3$, Gibbsite and Kaolinite). The sorbents were applied to cells 4 and 5 (40 and $50 \mathrm{~m}$ of flow distance)

$50 \mathrm{Hg}$ species distribution in EFPC water

$51 \mathrm{Hg}$ species sensitivity to temperature $\left(5-35^{\circ} \mathrm{C}\right)$ and $\mathrm{pH}(2-10)$ (unit in $\log$ $\mathrm{mol} / \mathrm{L})$; black box shows EFPC water $\mathrm{pH}$ range under oxidizing condition

52 Sensitivity of mineral precipitation to water temperature and $\mathrm{pH}$ in EFPC water conditions

53 Location of selected wells for Hg transport in Bear Creek Valley, Oak Ridge, TN (modified after Elvado Environmental LLC, 2009).

$54 \mathrm{Hg}$ transport model for Bear Creek Valley

55 Dissolved THg transported in the presence of three different sorbents, individually present in cells 34, 35 and 49, at Bear Creek Valley.....

56 Dissolved THg transported in the presence of two different sorbents, simultaneously present in cells 34,35 and 49, at Bear Creek Valley.... 
57 Comparison of $\mathrm{Hg}$-species and $\mathrm{pH}$ profiles along the flow distance between the model results and observed data. The points represent observed data and the lines represent model results

58 EFPC and Y-12 map (modified after www.esd.ornl.gov)

59 Initial concentration of $\mathrm{Hg}$ in EFPC water at different monitoring stations

60 Transport of dissolved $\mathrm{Hg}$ in EFPC water with loading rate of $2.5 \mathrm{~g} /$ day (from EFK 24.3 to EFK 13.8).

61 Total dissolved $\mathrm{Hg}$ concentration along the domain with $\mathrm{Hg}$ mass loading of $2.5 \mathrm{~g} / \mathrm{day}$.

62 Transport of dissolved $\mathrm{Hg}$ in EFPC water with $\mathrm{Hg}$ mass loading of $1.5 \mathrm{~g} /$ day (from EFK 24.3 to EFK 13.8)

63 Total dissolved $\mathrm{Hg}$ concentration along the domain with $\mathrm{Hg}$ mass loading of $1.5 \mathrm{~g} /$ day.

64 Transport of dissolved $\mathrm{Hg}$ in EFPC water with $\mathrm{Hg}$ mass loading of $0.5 \mathrm{~g} / \mathrm{day}$ (from EFK 24.3 to EFK 13.8)

65 Total dissolved $\mathrm{Hg}$ concentration along the domain with $\mathrm{Hg}$ mass loading of $0.5 \mathrm{~g} / \mathrm{day}$

66 Relationship between the concentration of total suspended solid and DOM in ENP water (Cai et al., 1999)

$67 \mathrm{Hg}$ speciation in ENP surface water. The black box represents the $\mathrm{pH}$ range of ENP surface water $(\mathrm{pH} 7.0-8.2)$.

68 ENP $\mathrm{Hg}$ species sensitivity to temperature $\left(5-35^{\circ} \mathrm{C}\right)$ and $\mathrm{pH}(2-10)$. The black box shows the ENP water $\mathrm{pH}$ range

69 Sensitivity of the mineral precipitation for ENP water with water temperature and $\mathrm{pH}$

70 Distribution of $\mathrm{Hg}$-species at various salinities (\%o)

71 The 3-D graphical distribution of $\mathrm{Hg}$-species as function of salinity (\%o) ......... 172

$72 \mathrm{Hg}$ species distribution at various pe in ENP water. 173

73 Map for the study area of $\mathrm{Hg}$ speciation distribution in ENP 176

74 Sub-areas in the ENP 


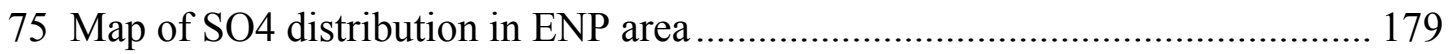

76 Map of $\mathrm{Hg}$ transport study area and model domain located in ENP Shark River Slough (modified after Harvey et al., 2005) ......................................... 180

77 Hg-DOC species transport in Shark River Slough $(0-200$ years $)$................... 185

$78 \mathrm{Hg}-\mathrm{DOC}$ concentration at NE5 and P33 stations at different time periods ........ 186

79 Hg-Peat complexation in Shark River Slough (0 - 200 years).......................... 188

$80 \mathrm{Hg}$-Peat concentration at NE5 and P33 stations at different time periods.......... 189

81 The transport of inorganic Hg in Shark River Slough (0 - 200 years)............... 191 


\section{ACRONYMS AND ABBREVIATIONS}

\begin{tabular}{|c|c|}
\hline ARD & Advection-Reaction-Dispersion \\
\hline $\mathrm{C}$ & Concentration \\
\hline $\mathrm{Ca}$ & Carbon \\
\hline $\mathrm{Cd}$ & Cadmium \\
\hline CEC & Cation Exchange Capacity \\
\hline $\mathrm{Cl}$ & Chloride \\
\hline $\mathrm{D}^{*}$ & Diffusion Coefficient \\
\hline $\mathrm{D}_{\mathrm{L}}$ & Dispersion Coefficient \\
\hline DO & Dissolved Oxygen \\
\hline DOC & Dissolved Organic Carbon \\
\hline DOM & Dissolved Organic Matter \\
\hline EFPC & East Fork Poplar Creek \\
\hline EFK & East Fork Kilometer \\
\hline ENP & Everglades National Park \\
\hline $\mathrm{Fe}$ & Iron \\
\hline GIS & Geographic Information Systems \\
\hline $\mathrm{Hg}$ & Mercury \\
\hline $\mathrm{K}_{\mathrm{d}}$ & Distribution Coefficient \\
\hline $\mathrm{MeHg}$ & Methyl Mercury \\
\hline $\mathrm{Mg}$ & Magnesium \\
\hline $\mathrm{Na}$ & Sodium \\
\hline OREIS & Oak Ridge Environmental Inform \\
\hline
\end{tabular}




$\begin{array}{ll}\text { ORR } & \text { Oak Ridge Reservation } \\ \mathrm{Pb} & \text { Lead } \\ \mathrm{RS} & \text { Reduced Sulfur } \\ \mathrm{S} & \text { Sulfur } \\ \mathrm{SFWMD} & \text { South Florida Water Management District } \\ \mathrm{SRS} & \text { Shark River Slough } \\ \mathrm{SO}_{4} & \text { Sulfate } \\ \mathrm{TSS} & \text { Total Suspended Solids } \\ u & \text { Water Velocity } \\ \mathrm{UEFPC} & \text { Upper East Fork Poplar Creek } \\ v & \text { Pore Velocity } \\ \mathrm{Y}-12 \mathrm{NSC} & \text { Y-12 National Security Complex } \\ \mathrm{Zn} & \text { Zinc } \\ \alpha_{\mathrm{L}} & \text { Longitudinal Dispersivity }\end{array}$




\section{INTRODUCTION AND LITERATURE REVIEW}

As part of this study, over 150 related publications were identified and reviewed. They are documented in the reference section. This section highlights the most relevant publications and state-of-the art knowledge and concerns about mercury $(\mathrm{Hg})$ in the aquatic environment.

\subsection{Background and Literature Review}

An awareness of $\mathrm{Hg}$ contamination in various aquatic environments from around the world has increased over the past decade. $\mathrm{Hg}$ is of concern because it is extremely toxic. Exposure to $\mathrm{Hg}$ in any of its forms under different circumstances may cause serious health problems, such as nervous system damage, immune system damage, chromosome damage and neurobehavioral disorders (Clarkson and Magos, 2006; Zahir et al., 2005). One of the worst disasters caused by mercury contamination is the Minamata disease. The contamination of Minamata Bay, Japan, occurred due to the releases of mercury from a chemical manufacturing plant during 1950 to 1971 . This resulted in mercury poisoning, causing an epidemic scale illness in fish and humans (Matsuyama et al. 2011; Tsuda et al. 2009). Since then, many other concerns related to $\mathrm{Hg}$ have come up.

$\mathrm{Hg}$ in the environment comes from two major sources. First, it is from the earth's crust. Second, it is from anthropogenic activities (e.g. manufacturing industry, fossil fuel power plant industry, etc.) (Fitzgerald, 2014; Pacyna 2002). These activities have resulted in the release of both forms of $\mathrm{Hg}$ (i.e. inorganic and organic forms) into the environment 
(Pacyna, 2002; Wang et al., 2004; Appelo and Postma, 2005). The Hg is transported to aquatic environments by soil erosion and discharge from anthropogenic activities (Wang et al., 2004; Appleo and Postma, 2005). There are different forms of $\mathrm{Hg}$ present in natural water, including elemental mercury $\left(\mathrm{Hg}^{0}\right)$, ionic mercury $\left(\mathrm{Hg}^{+}, \mathrm{Hg}^{2+}\right)$ and organic mercury [e.g., $\left(\mathrm{CH}_{3} \mathrm{Hg}^{+},(\mathrm{CH} 3)_{2} \mathrm{Hg}\right]$. Organomercury compounds are of concern because of their toxicity and ability to concentrate in the biota. These compounds are released into the environment as biocides, but can also be produced by enzymatic methylation of cations or due to reactions with biogenic methylating agents (Southworth et al., 2001; Ravichandran, 2004; Morel et al., 1993). The high animal tissue affinity of organomercury compounds, allows bioaccumulation and biomagnification of $\mathrm{MeHg}$ in aquatic organisms (e.g., fish) and humans to occur easier than other $\mathrm{Hg}$ species (Ravichandran, 2004; Dong et al., 2010).

Similarly to other metals, the fate of $\mathrm{Hg}$ in aquatic systems depends on its speciation, which is a function of the following processes (Facemire et al., 1995 Ravichandran, 2004; Morel et al., 1993):

- $\quad$ Precipitation and dissolution of minerals;

- Dissolution and dissociation of weakly acidic gases;

- $\quad$ Complexation with inorganic (e.g., $\mathrm{OH}^{-}, \mathrm{CO}_{3}{ }^{-}, \mathrm{SO}_{4}{ }^{2-}$ ) and organic (e.g., DOC constituents, such as humic and fulvic acids) ligands;

- $\quad$ Sorption on solids; and

- Biological activity.

Complexation, sorption and biological activity could be considered at thermodynamic equilibrium or under kinetic conditions, which may affect speciation. In 
addition, speciation also depends on the mixture of metals and complexing agents, $\mathrm{pH}$, temperature, redox, salinity, major ion composition and sorbing solids (Arias et al., 2004; Wang et al., 1991; Wnalin et al., 2007).

In the atmosphere, $\mathrm{Hg}$ occurs naturally and anthropogenically in its neutral or elemental state. $\mathrm{Hg}^{0}$ can be converted to an oxidized form of $\mathrm{Hg}$ (II) (Ravichandran, 2004; Dong et al., 2010). $\mathrm{Hg}(\mathrm{II})$ is transferred to the watersheds and water bodies through wet and dry deposition (Ravichandran, 2004). Reddy and Aiken (2001) reported that, in oxic/aerobic water, $\operatorname{Hg}(\mathrm{II})$ is bound to inorganic and organic ligands, hydroxide and chloride ligands, which depends on $\mathrm{pH}$ and chloride concentration, resulting in $\mathrm{Hg}(\mathrm{OH})^{+}$, $\mathrm{Hg}(\mathrm{OH})_{2}, \mathrm{Hg}(\mathrm{OH})_{3}{ }^{-}, \mathrm{HgCl}^{+}, \mathrm{HgCl}_{2}, \mathrm{HgCl}_{3}{ }^{-}, \mathrm{HgClOH}$ and $\mathrm{Hg}$-Humates (humic acid). Zhong and Wang, (2009) found that, in anoxic environments, inorganic and organic sulfides play an important role and bind mercury strongly, resulting in $\operatorname{HgS}_{0}, \operatorname{Hg}\left(\mathrm{S}_{2} \mathrm{H}\right)^{-}$, $\mathrm{Hg}(\mathrm{SH})_{2}$ and $\mathrm{Hg}(\mathrm{RS})^{+}$species (Zhong and Wang, 2009; Harmon et al., 2004; Jay et al., 2002; Karlsson and Skyllberg, 2003; Qian et al., 2002). The activity of sulfate-reducing bacteria (SRB) in the presence of mercury-sulfur compounds, promotes the methylation of mercury (Zhong and Wang, 2009; Harmon et al., 2004). The MeHg, that is produced by the bacteria in anoxic zones, transports to surface water and binds with inorganic and organic ligands to eventually be transferred and accumulated in biota through the food chain (Harmon et al., 2004; Bengtsson and Picado, 2008; Hill et al., 2010; Hintelmann et al., 1997). The study of $\mathrm{Li}$ et al. (2010) indicated that $\mathrm{MeHg}$ can be converted to a volatilized mercury form $\left(\mathrm{Hg}^{0}\right)$ through photodegradation (Li et al., 2010).

$\mathrm{Hg}$ has also been found to be in high concentration in sediment, from high absorption in clay (Arias et al., 2004; Reddy and Aiken, 2001); transport of Hg can thus 
occur through its attachment to sediment (Lui et al., 2008). The latter implies that site stratigraphy, sediment type, and distribution coefficient $\left(\mathrm{K}_{\mathrm{d}}\right)$ are important factors for estimating Hg transport in sediment (Reddy and Aiken, 2001).

\subsection{Rationale}

Because $\mathrm{Hg}$ fate and transport processes in an aquatic system are very complex, the study of these processes requires multiple disciplines of science including, geological, hydrological, chemical, biological and microbiological studies (Mackay et al., 1995; Parkhurst and Appelo, 1999; Appelo and Postma, 2005). The Hydro-geochemical model, PHREEQC, is a tool to integrate the processes affecting the fate and transport of the contaminants in an aquatic system. The PHREEQC model was selected for this study to assess the fate and transport of Hg. It is a chemistry and transport integrated model, which allows modelers to simulate the change of $\mathrm{Hg}$ chemical processes simultaneously with its transport in aquatic environment. However, it is recognized that there are many factors other than chemical processes (e.g., biological, microbiological processes) that can affect the fate of $\mathrm{Hg}$ in aquatic environments. For example, the activities of some bacteria and the effect of sunlight can transform $\mathrm{Hg}$ from one form to another (Li et al., 2010). This study emphasizes the chemical processes of $\mathrm{Hg}$, while its biological and microbiological processes are not considered. Use of PHREEQC model is a cost effective way for assessing the fate and transport of $\mathrm{Hg}$ in aquatic environments and for developing management plans for the reduction of $\mathrm{Hg}$ exposure in such systems. However, in order for the PHREEQC model to best represent the fate and transport of $\mathrm{Hg}$, further development of the model is needed. There are many challenges involved in developing 
PHREEQC model, which include the enhancement of $\mathrm{Hg}$ database of the model and testing and confirmation of the developed model.

\section{$1.3 \quad$ Research Gaps}

The combining of equilibrium and kinetic chemical reactions with the transport processes in models such as PHREEQC, improves the accuracy of predictions of the fate and transport of chemicals of interest in aquatic environments. Thus, a great variety of reactive transport problems and boundary conditions of interest to researchers and practitioners can now be addressed for aquatic systems. Because of the versatile capabilities and the reliability of the PHREEQC model, it has been used widely in geochemical research area by many researchers. It is definitely of great benefit to use this robust geochemical-transport model to predict and address the fate and transport of $\mathrm{Hg}$ in aqueous systems. However, in order to use PHREEQC to predict the fate and transport of $\mathrm{Hg}$, its $\mathrm{Hg}$ database needs to be improved. Although the model includes a $\mathrm{Hg}$ thermodynamic database, it only supports some speciation calculations. More specifically, it does not have a database for absorption processes that play a major role in the fate and transport of $\mathrm{Hg}$ in an aquatic system. Moreover, the existing $\mathrm{Hg}$ database only represents $\mathrm{Hg}$ speciation with much limitation.

\section{$1.4 \quad$ Research Objectives}

The research objectives are:

1. To develop, expand, and confirm the $\mathrm{Hg}$ database of the hydrogeochemical model "PHREEQC" to enhance its capability to 
simulate the fate of $\mathrm{Hg}$ species in the presence of complexing constituents and natural sorbents, under different conditions of $\mathrm{pH}$, redox, salinity and temperature.

2. To apply and evaluate the new database in flow and transport scenarios, at two field test beds: Oak Ridge Reservation, Oak Ridge, TN and Everglades National Park, FL, where Hg is present and of much concern.

\subsection{Research Questions}

Two important questions are answered at the completion of this research effort, as follows:

1. Can the enhanced database describe the difference in behavior of the various partitioning species when subjected to processes, such as dissolution/precipitation, ion exchange, and surface complexation?

2. Can the enhanced PHREEQC model be used in site applications to best understand the fate and transport of $\mathrm{Hg}$ in aquatic environments? 


\section{APPROACH}

In this study, the two test beds: Oak Ridge Reservation (ORR) at Oak Ridge, TN, Florida Everglades National Park (ENP), FL, are selected. The high Hg contamination in East Fork Poplar Creek (EFPC) located in the ORR area at Oak Ridge, TN, has raised concern among researchers due to the accidentally discharged and spilled $\mathrm{Hg}$ from the Y12 Plant into the surrounding environment in the 1950s (Southworth and Brooks, 2011). Dong et al. (2010) reported high concentration of MeHg in EFPC and found that neither total $\mathrm{Hg}$ nor dissolved inorganic $\mathrm{Hg}$ concentrations correlate with $\mathrm{MeHg}$ concentration in EFPC water. This suggests that speciation, mobility, and accumulation of $\mathrm{Hg}$ in EFPC are controlled by site aquatic, and geochemical characteristics, and conditions (Dong et al., 2010).

ENP is a unique wetland environment in the USA, with a subtropical ecosystem and wildlife, where its sediment and biota have been found to contain a very high level of Hg concentration (Axelrad et al., 2008; Feng et al., 2009; KBN 1992). As the researchers found at EFPC, the total $\mathrm{Hg}$ and $\mathrm{MeHg}$ concentration in ENP are uncorrelated (Dong et al., 2010; Feng et al. 2009; Duvall and Barron, 2000), which also suggests that site aqueous, geochemical characteristics, and conditions, such as complex types, sorbents, $\mathrm{pH}$, redox, temperature, dissolved organic carbon (DOC), etc., play an important role in the fate, that is transformation, mobilization, and accumulation of $\mathrm{Hg}$ in the aquatic environment (Evans and Engel, 1994; Ravichandran, 2004; Stumm and Morgan, 1996).

The development of a Hg thermodynamic database of the PHREEQC coupledtransport model will enhance the model capability to predict the $\mathrm{Hg}$ fate and transport in 
different aquatic environments. The enhanced model should then be a valuable tool to study the Hg behavior, fate and transport in selected test-beds. The approach used to enhance and develop the PHREEQC coupled transport model is described in this section. The research deliverable is also listed.

\subsection{Research Method}

The main tasks are the following:

1. Conduct a thorough literature review on thermodynamic properties $(\Delta \mathrm{H}$, stability constants) of $\mathrm{Hg}$ complexation including;

i. Speciation and dissolution/precipitation,

ii. Ion exchange, and

iii. Surface complexation (i.e., surface complexation constant for various minerals).

2. Improve the PHREEQC model's Hg thermodynamic database using the collected data in 1 .

3. Confirm the enhance PHREEQC coupled-transport model applicability to calculate the $\mathrm{Hg}$ chemical reaction processes, including speciation, ion exchange, and surface complexation and transport process using documented laboratory and field data.

4. Use the enhanced model to conduct the scenario base simulations including:

i. Effect of water pe, $\mathrm{pH}$, and temperature on $\mathrm{Hg}$ species distribution, 
ii. Sensitivity analysis of water pe, $\mathrm{pH}$, and temperature to $\mathrm{Hg}$ speciation distribution,

iii. Effect of exchangers, with the role of ion exchange, to $\mathrm{Hg}$ concentration in water,

iv. Effect of selected minerals, with the role of surface complexation, to $\mathrm{Hg}$ concentration in water,

v. Fate and transport of $\mathrm{Hg}$ in typical groundwater with the role of ion exchange and surface complexation, and

vi. Fate and transport of $\mathrm{Hg}$ in typical surface water with the role of ion exchange and surface complexation.

5. Use the enhanced PHREEQC coupled-transport model to study the $\mathrm{Hg}$ fate and transport in ORR and ENP test-bests.

i. Determine the chemical and physical factors that influence the $\mathrm{Hg}$ presence in the test-beds,

ii. Determine the main factors that affect the $\mathrm{Hg}$ immobilization and mobilization at the test-beds.

The default concentration unit, calculated by the model is molality (i.e. $\mathrm{mol} / \mathrm{kg}$ ), which is the ratio of the number of moles of solute to the mass of solvent. However, the model also allows the modeler to define the concentration in mass concentration unit, which is the ratio of mass of solute to the volume of solvent (e.g. mg/L, $\mu \mathrm{g} / \mathrm{L}$ ). The mass concentration unit (e.g. $\mathrm{mg} / \mathrm{L}, \mu \mathrm{g} / \mathrm{L}$ ) is used in this dissertation to report the results. This is to be consistent with the unit used in regulations established by the Environmental Protection Agency (EPA). 


\subsection{Research Deliverables}

1. The development of an enhanced PHREEQC database that is capable of best simulating $\mathrm{Hg}$ speciation under thermodynamic equilibrium conditions in the presence of complexing agents and natural sorbents (when the chemical processes of dissolution and precipitation, ion exchange, or surface complexation occur).

2. Development and analysis of the effects of $\mathrm{Hg}$ speciation in both batch mode and flow and transport simulations, at the two test beds, as a function of site characteristics and conditions that can affect the immobilization or mobilization of $\mathrm{Hg}$ species. 


\section{MODEL BACKGROUND AND THEORY}

This section describes the currently available hydrogeochemical models at the time this study was conducted. The best hydrogeochemical models, PHREEQC and PHAST, were selected based upon their capabilities to simulate the $\mathrm{Hg}$ chemical and transport processes. The governing equations of the models are also described in this section.

\subsection{Hydrogeochemical Modeling}

Hydrogeochemical modeling helps in understanding and predicting the difficult combination of chemical and mineral interrelated processes that control the fate of chemical species as well as the transport in aquatic environments. Hydrogeochemical models have developed in recent years to simulate the geochemical processes only (geochemical model) and to also simulate both geochemical processes and transport (i.e., flow and transport model). Geochemical models include GEMS, MINEQL+, MINTEQA2, and Visual MINTEQ, among others. Flow and transport models that have just become available in the very recent years are PHREEQC and PHAST models.

\subsubsection{Geochemical Modeling}

Geochemical models are mostly used to simulate chemical equilibrium with thermodynamic databases of the elements of environmental interest. Equilibrium models assume that all reactions have completed and are in equilibrium with one another. The models have common capabilities in calculating speciation, sorption, and precipitation of aquatic chemical components. The model capabilities are described as follows. 
GEMS: GEM-Selektor (GEM-Selektor Geochemical Software) was developed by Paul Scherer Institute in Switzerland. It is an interactive thermodynamic modeling of heterogeneous aquatic geochemical systems. The model uses the method of Gibbs Energy Minimization to calculate the multi-speciation at the equilibrium. It has capabilities to calculate aqueous-solid solution equilibrium, adsorption and ion exchange. It includes a built-in (default) thermodynamic database of common aqueous elements. The model provides the option for extension and modification of its database by the modeler.

MINEQL+: It was first developed at MIT, by John Westall and Francois Morel. It has abilities to perform the calculation of equilibrium aqueous speciation, of dissolved and solid phases, adsorption and ion exchange, at low temperature $\left(0-50{ }^{\circ} \mathrm{C}\right)$ and low to moderate ionic strength $(<0.5 \mathrm{M})$. The MINEQL + version 3 is available for the DOS operating system and is free for use, while version 4.6 is available for the window operating system, but at a cost to the modeler (MINEQL+, Geochemical Software).

MINTEQA2: This program is sponsored by the US Environmental Protection Agency (USEPA). It is an equilibrium speciation model, alike other geochemical models. MINTEQA2 has capabilities to calculate dissolved and solid phases and adsorption. The thermodynamic database in MINTEQA2 is well developed, including common aqueous elements. MINTEQA2 is a free and robust geochemical model that has been used by researchers. It is available for the DOS operating system (MINTEQA2, Geochemical Software).

Visual MINTEQ: It is a development of MINTEQA2; it has been maintained by Jon Petter Gustafsson at KTH, Sweden, since 2000. It has capabilities to calculate 
aqueous equilibrium reactions as MINTEQA2. The difference with MINTEQ is that Visual MINTEQ is available for the windows operating system (Visual MINTEQ).

\subsubsection{Flow and Transport}

PHREEQC and PHAST models are models that handle the kinetics of chemical reactions, reverse reactions and link the concentrations of species to simulations of 1dimensional (PHREEQC) and 3-dimensional (PHAST) transport scenarios (U.S. Geological Survey, 1999 and 2010).

PHREEQC: It is a product of the US Geological Survey (USGS), developed by Parkhurst and Appelo in 1999. It is designed to perform low-temperature aqueous geochemical calculations. It is similar to other geochemical models having capabilities to calculate speciation, saturation index, batch reaction, surface complexion, adsorption and ion exchange at equilibrium. In addition, PHREEQC also has capabilities to simulate reversible reactions, kinetic reactions, with rate expressions defined by the modeler and one dimensional (1-D) transport simulations. Its databases contain those from MINTEQA2 and other USGS's models (i.e., WATEQF4). All these capabilities make PHREEQC more complete and advanced model than others. The coupling of geochemical and transport processes in PHREEQC allows the studying the behavior of aqueous components under flow and transport conditions at sites of interest. The model can link the chemical equilibrium (i.e., batch-reaction) calculations to simulations of flow and transport under two types of boundaries and time conditions (i.e., flux or third-type boundary and the Dirichlet or first-type) (see Appendix A for details of PHREEQC model's capabilities and limitations). 
PHAST: It is an integrated computer program between Geochemical model (PHREEQC) and the flow model (HST3D). PHAST is designed to simulate multicomponent, reactive solute transport in 3-dimensional flow system. The calculations of flow and transport are based on a developed HST3D model (Parkhurst et al., 2010) while the geochemical reactions are simulated with the geochemical model PHREEQC (Parkhurst, 1995; Parkhurst and Appelo, 1999). The PHREEQC model is embedded in PHAST (see Appendix B for details of PHAST model's capabilities and limitations). Current hydrogeochemical model capabilities are summarized in Table 1.

Table 1 The main features and capabilities of available hydrogeochemical models

\begin{tabular}{|c|c|c|c|c|c|c|c|c|}
\hline Models & $\underset{\text { database }}{\mathrm{Hg}}$ & $\begin{array}{l}\text { Expandable } \\
\text { database }\end{array}$ & $\begin{array}{l}\text { Saturation } \\
\text { Index } \\
\text { calculation }\end{array}$ & $\begin{array}{c}\text { Precipitation } \\
\text { Calculation }\end{array}$ & $\begin{array}{l}\text { Sorption } \\
\text { processes }\end{array}$ & $\begin{array}{c}\text { Inverse } \\
\text { model }\end{array}$ & $\begin{array}{l}\text { Transport } \\
\text { processes }\end{array}$ & System \\
\hline GEMS & A & G & G & G & A & $\mathrm{Na}$ & na & Windows \\
\hline MINEQL & A & L & G & G & A & $\mathrm{Na}$ & na & DOS \\
\hline $\begin{array}{c}\text { MINTEQA } \\
2\end{array}$ & A & $\mathrm{L}$ & G & G & G & $\mathrm{Na}$ & na & DOS \\
\hline $\begin{array}{c}\text { Visual } \\
\text { MINTEQ }\end{array}$ & A & L & G & G & A & $\mathrm{Na}$ & na & Windows \\
\hline PHREEQC & A & G & G & G & G & G & G & Windows \\
\hline PHAST & A & G & G & G & G & G & G & DOS \\
\hline
\end{tabular}

A: Average-comparable to other models; G: Good-better than other models; L: Limited; na: not available 
All of the Hg databases available in PHREEQC and PHAST models are for speciation calculations of common inorganic $\mathrm{Hg}$ species, but they lack organic complexation, ion exchange and sorption stability constants.

PHREEQC and PHAST are thus the chosen models to support this research because of their various capabilities (Appelo and Postma, 2005; Halim et al., 2005; Parkhurst and Appelo, 1999; Tiruta-Barna, 2008). It is foreseen that, once the databases are enhanced, it will allow a more objective assessment and analysis of the fate of $\mathrm{Hg}$, in flow and transport conditions, at the two applications test beds, namely, EFPC and ENP, where $\mathrm{Hg}$ is present and of concern.

\subsection{PHREEQC and PHAST Governing Equations}

The combined implementation of these models, products of the USGS, offers a mathematical framework to perform a wide variety of low-temperature aqueous geochemical calculations and to simulate dispersion (or diffusion) and stagnant zones in 1D-transport (PHREEQC) and 3D-transport calculations. It was mentioned earlier that PHREEQC model is embedded in PHAST and used to calculate the geochemical reactions. The geochemical reactions (aqueous, exchange, and surface species at equilibrium) in both PHREEQC and PHAST are calculated using the activities and massaction equations of an aqueous chemical system. The transport of substances of interest in the system is predicted by the advection-reaction-dispersion equations.

\subsubsection{Activity and Mass-Action Equations}

The activity and mass-action relation for each species in the models can be defined by the modeler. Models then derive the unknown mole of the species (i) from the 
mass-action relation. The mole of $i$ in the system is then calculated by differentiation of equations derived with respect to $i$ (Parkhurst and Appelo, 1999).

\subsubsection{Solution species}

PHREEQC calculates the aqueous species at the thermodynamic equilibrium. However disequilibrium in the initial solution is allowed. For each aqueous species $i$, the unknowns: activity, $a_{i}$, activity coefficient, $\gamma_{i}$, molality, $m_{i}$, and moles in solution, $n_{i}$ will be calculated by PHREEQC. The following relationship $a_{i}=\gamma_{i} m_{i}$ and $n_{i}=m_{i} W_{a q}$ apply for all aqueous species ( $W_{a q}$ is the mass of solvent water in an aqueous solution) (Parkhurst and Appelo, 1999). For example, the association reaction of the aqueous species is $\mathrm{Hg}(\mathrm{OH})_{2}+2 \mathrm{H}^{+}=\mathrm{Hg}^{2+}+2 \mathrm{H}_{2} \mathrm{O}$. The $\log \mathrm{K}$ for this reaction at $25^{\circ} \mathrm{C}$ is 6.09 , which results in the mass-action equation:

$$
10^{6.09}=\frac{\left[\mathrm{Hg}^{2+}\right]}{\left[\mathrm{Hg}(\mathrm{OH})_{2}\right]\left[\mathrm{H}^{+}\right]^{2}}
$$

In general, mass-action equations can be written as equation 2 .

$$
K_{i}=a_{i} \prod_{m}^{M a q} a_{m}^{-C_{m, i}}
$$

where: $\quad K_{i}=$ a temperature-dependent equilibrium constant

$$
\begin{aligned}
& \mathrm{c}_{\mathrm{m}, \mathrm{i}}= \text { the stoichiometric coefficient of master species } \mathrm{m} \text { in the species } \mathrm{i} \text {, } \\
& \text { the value can be positive or negative } \\
& \mathrm{M}_{\mathrm{aq}}=\text { the total number of aqueous master species }
\end{aligned}
$$

From mass-action expression, the mole of aqueous species $i$ can be derived as equation 3

$$
n_{i}=m_{i} W_{a q}=K_{i} W_{a q} \frac{\prod_{m}^{M a q} a_{m}^{c_{m, i}}}{\gamma_{i}}
$$


PHREEQC then uses the Newton-Raphson method to differentiate the total number of moles with respect to an unknown (see equation 4).

$$
d n_{i}=n_{i}\left[d \operatorname{In}\left(W_{a q}\right)+\sum_{m}^{M a q} C_{m, i} d \operatorname{In}\left(a_{m}\right)-\frac{\partial}{\partial \mu} \operatorname{In}\left(\gamma_{i}\right) d I\right]
$$

The activity coefficient $\gamma_{i}$ is expressed as a function of ionic strength, $I$ (Davies equation). The relationship between $\gamma_{i}$ and $I$ of aqueous species in PHREEQC is defined as equation 5. The partial derivatives of the activity coefficient equation with respect to ionic strength are shown in equation 6 (Parkhurst and Appelo, 1999).

$$
\begin{aligned}
& \log \gamma_{i}=-A z_{i}^{2}\left(\frac{\sqrt{I}}{1+\sqrt{I}}-0.3 I\right) \\
& \frac{\partial}{\partial I} \operatorname{In} \gamma_{i}=-\operatorname{In}(10)\left(\frac{A z_{i}^{2}}{2 \sqrt{I}\left(B a_{i}^{0} \sqrt{I}+1\right)^{2}}+b_{i}\right)
\end{aligned}
$$

where $A$ is constant which is only dependent on temperature, and $z_{i}$ is the ionic charge of aqueous species $i$.

In PHREEQC, the modeler will need to define and input the chemical equation for the mole-balance and mass-action expressions, the $\log \mathrm{K}, \Delta \mathrm{H}$, and the activity coefficient parameters for each aqueous species. PHREEQC will then calculate the aqueous species using equations 1-6 (Parkhurst and Appelo, 1999).

\subsubsection{Exchange species}

PHREEQC calculates the ion-exchange at equilibrium using mass-action expressions based on half-reactions between aqueous species and an unoccupied exchange site (Appelo and Postma, 2005) for each exchanger $e$, The unknowns of each exchange species $i_{e}$ of exchanger $e$ that will be calculated by PHREEQC are the activity, 
$a_{i_{e}}$, and the moles, $n_{i_{e}}$. PHREEQC defines $a_{i_{e}}$ to be the equivalent fraction times an activity coefficient $\gamma_{i_{e}}$. The equivalent fraction is the moles of sites occupied by an exchange species $\left(b_{e, i_{e}} n_{i_{e}}\right.$ where $b_{e, i_{e}}$ is the number of equivalents of exchanger $e$ occupied by the exchange speciesi) divided by the total number of exchange sites $\left(T_{e}\right)$. The $a_{i_{e}}$ thus can be expressed as equation 7 (Parkhurst and Appelo, 1999).

$$
a_{i_{e}}=\gamma_{i_{e}} \frac{b_{e, i_{e}} n_{i_{e}}}{T_{e}}
$$

The mass-action for exchanged species is required in PHREEQC. For example, the association reaction for the exchange species $\mathrm{HgX}_{2}$ is $\mathrm{Hg}^{2+}+2 \mathrm{X}^{-}=\mathrm{HgX}_{2}$ where $\mathrm{X}^{-}$is the exchange master species in the default database. The $\log \mathrm{K}$ for $\mathrm{Hg}$ half-exchange reaction derived from literature is -1.39 , thus the mass-action reaction can be written as equation 8 (Parkhurst and Appelo, 1999).

$$
10^{-1.39}=\frac{\left[H g X_{2}\right]}{\left[H^{2+}\right]\left[X^{-}\right]^{2}}
$$

In general, mass-action equations can be written as equation 9 .

$$
K_{i e}=a_{i_{e}} \prod_{m}^{M} a_{m}^{-C_{m, i_{e}}}
$$

where:

$$
\begin{aligned}
K_{i_{e}}= & \text { half-reaction selectivity constant } \\
c_{m, i_{e}}= & \text { the stoichiometric coefficient of master species } m \text { in species } i_{\mathrm{e}} \text {, the } \\
& \text { value can be positive or negative }
\end{aligned}
$$

From mass-action expression, the mole of species $i_{e}$ can be derived as equation 10 . 


$$
n_{i_{e}}=K_{i_{e}} \frac{\prod_{m}^{M} a_{m}^{C_{m, i_{e}}}}{\gamma_{i_{e}}\left(\frac{b_{e, i_{e}}}{T_{e}}\right)}
$$

PHREEQC then calculates the total derivative of the moles of species $i_{e}$ with respect to the master unknowns as in equation 11 (Parkhurst and Appelo, 1999).

$$
d n_{i_{e}}=n_{i_{e}}\left[\sum_{m}^{M} C_{m, i_{e}} d \operatorname{In}\left(a_{m}\right)-\frac{\partial}{\partial I} \operatorname{In}\left(\gamma_{i_{e}}\right) d I\right]
$$

PHREEQC requires the modeler to define and input the chemical equation for the molebalance and mass-action expressions, the $\log \mathrm{K}, \Delta \mathrm{H}$, and the activity coefficient parameters for each exchange species. PHREEQC will then calculate the unknowns of each exchange species $i_{e}$ using equations 8-11.

\subsubsection{Surface species}

The differences between the surface complexation and the ion exchange defined in PHREEQC are that the surface reactions are not half-reactions and surface species may be anionic, cationic, or neutral. PHREEQC calculates the surface complexation processes using the theory proposed by Dzombak and Morel (1990). This theory assumes that the number of active sites, $T_{\mathrm{s}}$, the specific area, $\mathrm{A}_{\mathrm{s}}\left(\mathrm{m}^{2} / \mathrm{g}\right)$, and the mass, $\mathrm{S}_{\mathrm{s}}(\mathrm{g})$, of the surface are defined. PHREEQC assumes the activity of a surface species to be equal to the mole fraction of a given surface-site type that is occupied. This means that a surface species has an activity of 1 when it completely covers a given kind of surface site (Parkhurst and Appelo, 1999).

In the default PHREEQC database the surface of ferrihydrite is defined as "Hfo". Hfo_s represents a high affinity or a strong site while Hfo_w is a week site. In 
PHREEQC the neutral surface species at weak and strong sites of ferrihydrite are defined as "Hfo_wOH" and "Hfo_sOH" and the surface association reaction with $\mathrm{Hg}$ (for a weak site) can be written as $\mathrm{Hfo} \_w O H+\mathrm{Hg}(\mathrm{OH})_{2}+\mathrm{H}^{+}=\mathrm{Hfo}_{-} \mathrm{wOHg}^{+}+2 \mathrm{H}_{2} \mathrm{O}$. The massaction can be expressed as equation 12 (Parkhurst and Appelo, 1999).

$$
K_{\text {int }}=\frac{\left[H f o_{-} w H g^{+}\right]}{\left[H f o_{-}{ } \mathrm{OH}\right]\left[\mathrm{Hg}(\mathrm{OH})_{2}\right]\left[\mathrm{H}^{+}\right]} e^{-\frac{F \psi_{s}}{R T}}
$$

where $K_{\text {int }}$ is the intrinsic equilibrium constant, $\mathrm{F}$ is the Faraday constant $\left(96493.5 \mathrm{~J} \mathrm{~V}^{-1}\right.$ eq $\left.{ }^{-1}\right)$, is the potential at surfaces (volts), $\mathrm{R}$ is the gas constant $\left(8.3147 \mathrm{~J} \mathrm{~mol}^{-1} \mathrm{~K}^{-1}\right), \mathrm{T}$ is temperature (Kelvin) and the term $e^{-\frac{F \psi_{S}}{R T}}$ is a factor that indicates the work involved in moving a charged species $\left(\mathrm{H}^{+}\right)$away from a charged surface (Parkhurst and Appelo, 1999).

In general, mass-action equations can be written as equation 13:

$$
K_{\mathrm{int}, i_{\left(s_{k}\right)}}=\left(a_{i\left(s_{k}\right)} \prod_{m}^{M} a_{m}^{-C_{\left.m, i_{\left(s_{k}\right)}\right)}}\right) e^{\frac{F \psi_{s}}{R T} \Delta Z_{i\left(s_{k}\right)}}
$$

where the subscript $\left(\mathrm{s}_{\mathrm{k}}\right)$ indicates the parameter for surface-site type $\mathrm{k}$ (weak or strong in Dzombak and Morell, 1990) in surface s, and $\Delta Z i_{\left(s_{k}\right)}$ is the net change in surface charge due to the formation of the surface species (Parkhurst and Appelo, 1999).

The derived equation for the total mole of surface species $i_{\left(s_{k}\right)}$ is shown in equation 14:

$$
n_{i_{\left(s_{k}\right)}}=K_{i\left(s_{k}\right)} T_{s_{k}} e^{\left(\frac{F \psi_{s}}{R T} \Delta Z_{i\left(s_{k}\right)}\right)} \prod_{m}^{M} a_{m}^{C_{m, i_{\left(s_{k}\right)}}}=K_{i\left(s_{k}\right)} \frac{T_{s_{k}}}{b_{i_{\left(s_{k}\right)}}} a_{\psi_{s}}{ }^{-2 \Delta Z_{i\left(s_{k}\right)}} \prod_{m}^{M} a_{m}^{C_{m, i}\left(s_{k}\right)}
$$

PHREEQC calculates the total derivative of the moles of the species $i_{\left(s_{k}\right)}$ with respect to the master unknowns using equation 15: 


$$
d n_{i_{\left(s_{k}\right)}}=n_{i_{\left(s_{k}\right)}}\left[\sum_{m}^{M} C_{m, i_{\left(s_{k}\right)}} d \operatorname{In} a_{m}-2 \Delta z_{i_{\left(s_{k}\right)}} d \operatorname{In} a_{\psi_{s}}\right]
$$

Modelers are required to input the chemical equation for the mole-balance and massaction expressions, the $\log \mathrm{K}, \Delta \mathrm{H}$, and surface properties (surface area, surface type, and the number of equivalents of each site type). PHREEQC then calculates the unknown of surface species $i$ using equations 12-15.

\subsubsection{Transport Equations for Ground and Surface Water}

PHREEQC has the capability to calculate and combine all the chemical reactions with transport processes. The transport processes that can be simulated by PHREEQC include diffusion, advection, advection and dispersion, and advection and dispersion with diffusion into the stagnant zone (Parkhurst and Appelo, 1999).

\subsubsection{Advection-reaction-dispersion in PHREEQC model}

The 1D-transport processes in PHREEQC are governed by the AdvectionReaction-Dispersion (ARD) equation. PHREEQC makes availability for the equation to be used for both ground and surface water flow simulations by modeler defined parameters (i.e., velocity). Equation 16 is used to simulate the groundwater flow while equation 17 is for surface water flow.

$$
\begin{aligned}
& \frac{\partial C}{\partial t}=-v \frac{\partial C}{\partial x}+D_{L} \frac{\partial^{2} C}{\partial x^{2}}-\frac{\partial q}{\partial t} \\
& \frac{\partial C}{\partial t}=-u \frac{\partial C}{\partial x}+D_{L} \frac{\partial^{2} C}{\partial x^{2}}-\frac{\partial q}{\partial t}
\end{aligned}
$$

where $v$ is the average pore water flow velocity $(\mathrm{m} / \mathrm{d}), \mathrm{u}$ is the average stream velocity $(\mathrm{m} / \mathrm{d}), x$ is the distance $(\mathrm{m}), C$ is concentration in water $(\mathrm{mol} / \mathrm{L}), D_{L}$ is the dispersion 
coefficient $\left[\mathrm{m}^{2} / \mathrm{d}, D_{L}=\alpha_{L} v+D^{*}\right.$ is for groundwater flow, while $D_{L}=\alpha_{L} u+D^{*}$ is for surface water flow, where $\alpha_{\mathrm{L}}$ is longitudinal dispersive $(\mathrm{m})$, and $\mathrm{D}^{*}$ is the diffusion coefficient $\left.\left(\mathrm{m}^{2} / \mathrm{d}\right)\right]$, and $q$ is the concentration in a solid phase $(\mathrm{mol} / \mathrm{L})$. The first term on the right hand-side of the earlier equations, $-v \frac{\partial C}{\partial x}$ and $-u \frac{\partial C}{\partial x}$ represent advection, the second term $D_{L} \frac{\partial^{2} C}{\partial x^{2}}$ represents dispersion, and $\frac{\partial q}{\partial t}$ represents the change in concentration due to a reaction (e.g., sorption, ion exchange, etc.). Equation 17 was recognized and successfully used by a number of researchers (Fried, 1991; Tradiff and Goldstein, 1991) to calculate the change of chemicals and substances in the stream flow.

\subsubsection{Advection-reaction-dispersion in PHAST model}

The governing equation of flow and transport in the PHAST model includes advection, dispersion, and the reactions. The PHAST model also can be used to calculate both ground and surface water flows. Groundwater flow can be calculated using equation 18, in which the Darcy velocity $(v)$ and porosity $(\varepsilon)$ of the media are important parameters and defined by the modeler.

$$
\frac{\partial}{\partial t}\left(\varepsilon \rho c_{i}\right)=\nabla \bullet \varepsilon D \nabla \rho c_{i}-\nabla \bullet \varepsilon v \rho c_{i}-\sum_{e=1}^{N_{E}} v_{i, e}^{E} \frac{\partial}{\partial t}\left(\varepsilon \rho \bar{c}_{e}\right)+\sum_{k=1}^{N_{K}} v_{i, k}^{K} \varepsilon \rho R_{k}+q \varepsilon \rho \hat{c}_{i}
$$

According to Parkhurst et al. (2010) and Parkhurst and Appelo (1999), "where $v=-\frac{K}{\varepsilon} \nabla h, K$ is hydraulic conductivity, $\nabla h$ is potentiometric head $(\mathrm{m}) ; c_{i}$ is the total aqueous concentration of component $i(\mathrm{~mol} / \mathrm{kgw}) ; D$ is the dispersion-coefficient tensor $\left(\mathrm{m}^{2} / \mathrm{s}\right) ; N_{E}$ is the number of heterogeneous equilibrium reactions; $v_{i, k}^{K}$ is the stoichiometric 
coefficient of component $i$ in heterogeneous equilibrium reaction e (unitless); $\bar{c}_{e}$ is the concentration of solid reactant e (mol/kgw); $N_{K}$ is the number of kinetic reactions; $v_{i, k}^{K}$ is the stoichiometric coefficient of component $\mathrm{i}$ in kinetic reaction $\mathrm{k}$ (unitless); $R_{k}$ is the rate of kinetic reaction $k$ (mol kgw ${ }^{-1} \mathrm{~s}^{-1}$ [moles per kilogram of water per second]); $\widehat{c}_{i}$ is the total aqueous concentration of component $i$ in the source water (mol/ $/ \mathrm{kgw})$; and $N_{c}$ and is the number of chemical components in the system".

Substitution of $v$ in equation 18 by $-\frac{K}{\mathcal{E}} \nabla h$ produces Equation 19, which indicates that $K$ and $\varepsilon$ must be defined by the modeler for groundwater flow simulation.

$$
\frac{\partial}{\partial t}\left(\varepsilon \rho c_{i}\right)=\nabla \bullet \varepsilon D \nabla \rho c_{i}-\nabla \bullet K \nabla h \rho c_{i}-\sum_{e=1}^{N_{E}} v_{i, e}^{E} \frac{\partial}{\partial t}\left(\varepsilon \rho \bar{c}_{e}\right)+\sum_{k=1}^{N_{K}} v_{i, k}^{K} \varepsilon \rho R_{k}+q \varepsilon \rho \hat{c}_{i}
$$

In case of surface water flow, the following considerations are made: 1) the $\varepsilon$ is constantly equal to 1 , where the volume of void space is the total volume $\left(\mathrm{V}_{\mathrm{d}} / \mathrm{V}_{\mathrm{T}}=1\right)$. This is when the sediment is present in the stream bed but does not affect the stream velocity; and 2) the density of water $(\rho)$ is constant. With these assumptions, the $\varepsilon$ and $\rho$ in equation 19 can be cancelled, and average stream velocity $u$ can be substituted. Thus, the equation for surface water flow is written as equation 20 :

$$
\frac{\partial}{\partial t} c_{i}=\nabla \bullet D c_{i}-\nabla \bullet u c_{i}-\sum_{e=1}^{N_{E}} v_{i, e}^{E} \frac{\partial}{\partial t}\left(\bar{c}_{e}\right)+\sum_{k=1}^{N_{K}} v_{i, k}^{K} R_{k}+q \hat{c}_{i}
$$

Equation 20 is the simplified advection-dispersion-reaction equation, where the first term on the right-hand side represents advection, the second term represents dispersion and the rest is the change within concentration $C$ due to the reactions and input. 


\subsubsection{Transport boundary conditions}

There are two boundary types that can be considered for the transport: 1) constant, and 2) flux conditions.

The constant boundary condition is expressed by equations 21-24. The error function, A, for groundwater flow is calculated using equation 23, while equation 24 is for surface water flow.

$$
\begin{aligned}
& \text { at } \mathrm{x}=0 ; \quad C(0, t)=C_{0} \\
& \text { at } \mathrm{x}>0 ; \quad C(x, t)=C_{i}+\frac{1}{2}\left(C_{0}-C_{i}\right) A \\
& A=\operatorname{erfc}\left(\frac{x-v t / R}{\sqrt{4 \alpha_{L} v t / R}}\right)+\exp \left(\frac{x}{\alpha_{L}}\right) \operatorname{erfc}\left(\frac{x+v t / R}{\sqrt{4 \alpha_{L} v t / R}}\right) \\
& A=\operatorname{erfc}\left(\frac{x-u t / R}{\sqrt{4 \alpha_{L} u t / R}}\right)+\exp \left(\frac{x}{\alpha_{L}}\right) \operatorname{erfc}\left(\frac{x+u t / R}{\sqrt{4 \alpha_{L} u t / R}}\right)
\end{aligned}
$$

where $x$ is the distance $(\mathrm{m}), \mathrm{t}$ is time $(\mathrm{s}), v$ is velocity $(\mathrm{m} / \mathrm{s}), \alpha_{\mathrm{L}}$ is longitudinal dispersion (m), and $R$ is the retardation that is caused by the media CEC in the case of groundwater flow (Eq. 23) and sediment CEC in surface water flow (Eq. 24) $\left(1+\frac{C E C}{C}\right.$, where $C E C$ is expressed in $\mathrm{mol} / \mathrm{L}$ and $C$ is the concentration in $\mathrm{mol} / \mathrm{L}$ ).

The flux boundary condition is shown in equations $25-28$. The error function B for groundwater flow is expressed in equation 27, while equation 28 is for surface water flow.

Flux boundary condition:

$$
\text { at } \mathrm{x}=0 ; \quad C(0, t)=C_{0}+\frac{D_{L}}{v} \frac{\partial C\left(x_{\text {end }}, t\right)}{\partial x}
$$




$$
\begin{gathered}
\text { at } \mathrm{x}>0 ; \\
C(x, t)=C_{i}+\frac{1}{2}\left(C_{0}-C_{i}\right) B \\
B=\operatorname{erf}\left(\frac{x-v t / R}{\sqrt{4 \alpha_{L} v t / R}}\right)+\sqrt{\left(\frac{x}{\pi \alpha_{L}}\right)} \exp \left[-\frac{(x-v t / R)^{2}}{4 \alpha_{L} v t / R}\right]-\frac{1}{2}\left(1+\frac{x}{\alpha_{L}}+\frac{v t / R}{\alpha_{L}}\right) \exp \left(\frac{x}{\alpha_{L}}\right) \operatorname{erf}\left(\frac{x+v t / R}{\sqrt{4 \alpha_{L} v t / R}}\right) \\
B=\operatorname{erfc}\left(\frac{x-u t / R}{\sqrt{4 \alpha_{L} u t / R}}\right)+\sqrt{\left(\frac{x}{\pi \alpha_{L}}\right)} \exp \left[-\frac{(x-u t / R)^{2}}{4 \alpha_{L} u t / R}\right]-\frac{1}{2}\left(1+\frac{x}{\alpha_{L}}+\frac{u t / R}{\alpha_{L}}\right) \exp \left(\frac{x}{\alpha_{L}}\right) \operatorname{erf}\left(\frac{x+u t / R}{\sqrt{4 \alpha_{L} u t / R}}\right)
\end{gathered}
$$

The retardation $\mathrm{R}$ in equation 33 is caused by the CEC of the transport media for ground water flow, while R in equation 34 is caused by CEC in the case of streambed sediment. 


\section{MODEL DEVELOPMENT}

This section describes the model development, including Hg thermodynamic properties used for database enhancement and model confirmation.

\subsection{Enhanced Model Database Input Method}

In this section, the model database input method and the model language are described. The Hg thermodynamic data collected from the literature are also added into the model database for all aqueous, ion exchange, and surface species.

\subsubsection{Hg Dissolution and Precipitation}

In order to calculate the aqueous species, PHREEQC requires all master species to be defined in the "MASTER SOLUTION_SPECIES" block in the PHREEQC database. $\mathrm{Hg}$ master species is defined under this block as $\mathrm{Hg}(\mathrm{OH})_{2}$ species. As shown below, the alkalinity and the element gram formula weight of $\mathrm{Hg}$ are also required in this data block.

SOLUTION_MASTER_SPECIES

$\begin{array}{cccc}\text { Element name } & \text { Master Species } & \text { Alkalinity } & \begin{array}{c}\text { Element gram } \\ \text { formula weight }\end{array} \\ \mathrm{Hg} & \mathrm{Hg}(\mathrm{OH})_{2} & 0.0 & 200.59\end{array}$

The chemical reaction, $\log \mathrm{K}$, and $\Delta \mathrm{H}$ of each $\mathrm{Hg}$ aqueous species must be defined in "SOLUTION_SPECIES" data block. The collected aqueous thermodynamic data can be added. However, the reactions must be written with $\mathrm{Hg}(\mathrm{OH})_{2}$ species since it is defined 
as the master species for the $\mathrm{Hg}$ element in the database. The $\mathrm{Hg}$ thermodynamic and log $\mathrm{K}$ data collected from the literature are $\mathrm{Hg}^{2+}$ related reactions. However, since the $\mathrm{Hg}(\mathrm{OH})_{2}$ is defined as the master species for $\mathrm{Hg}$, the collected thermodynamic data must be converted to $\mathrm{Hg}(\mathrm{OH})_{2}$ related reactions and $\log \mathrm{K}$ prior to adding into the PHREEQC database. The example of a conversion is shown next and in equations 29-32.

The relationship between $\mathrm{Hg}(\mathrm{OH})_{2}$ and $\mathrm{Hg}^{2+}$ is:

$\mathrm{Hg}(\mathrm{OH})_{2}+2 \mathrm{H}^{+}=\mathrm{Hg}^{2+}+2 \mathrm{H}_{2} \mathrm{O}$

$$
\log \mathrm{K}=6.19
$$

and the reaction related to $\mathrm{Hg}^{2+}$ is:

$$
\begin{aligned}
\mathrm{Hg}^{2+}+\mathrm{HPO}_{4}{ }^{3-} & =\left(\mathrm{HgHPO}_{4}\right)^{-} \\
\log \mathrm{K} & =9.5 \quad \text { (Quarfort-Dahlman 1975) }
\end{aligned}
$$

The above reactions (including $\log \mathrm{K}$ ) can be combined to become a new reaction related to $\mathrm{Hg}(\mathrm{OH})_{2}$ (equation 30), as shown next:

The combined equation is then:

$$
\begin{gathered}
\mathrm{Hg}(\mathrm{OH})_{2}+2 \mathrm{H}^{+}+\mathrm{Hg}^{2+}+\mathrm{HPO}_{4}{ }^{3-}=\mathrm{Hg}^{2+}+2 \mathrm{H}_{2} \mathrm{O}+\left(\mathrm{HgHPO}_{4}\right)^{-} \\
\log \mathrm{K}=15.69
\end{gathered}
$$

However, since " $\mathrm{Hg}^{2+}$ " appears on both sides of the combined equation (equation 30), it can be subtracted from both sides. The final combined reaction (and Log K), which relates to $\mathrm{Hg}(\mathrm{OH})_{2}$, is shown in equation 31:

$$
\begin{gathered}
\mathrm{Hg}(\mathrm{OH})_{2}+2 \mathrm{H}^{+}+\mathrm{HPO}_{4}{ }^{3-}=\left(\mathrm{HgHPO}_{4}\right)^{-}+2 \mathrm{H}_{2} \mathrm{O} \\
\log \mathrm{K}=15.69
\end{gathered}
$$

The Hg aqueous species data related to $\mathrm{Hg}(\mathrm{OH})_{2}$ added into the PHREEQC database, are shown in Appendix C. 


\subsubsection{Hg Ion-Exchange}

In the PHREEQC database, the master exchanger $X$ with one negative valence number $(X)$, which represents the negative charge of typical soil and sediment, is defined under EXCHANGE_MASTER_SPECIES block.

\section{EXCHANGE_MASTER_SPECIES \\ $\begin{array}{cc}\text { Element name } & \text { Master Species } \\ \mathrm{X} & \mathrm{X}^{-}\end{array}$}

The exchange half-reaction must be defined under the EXCHANGE_SPECIES block. As it was mentioned earlier, the $\mathrm{Hg}$ exchange species data is not available in the PHREEQC database, therefore, the Hg exchange species and their exchange coefficients obtained from Khan and Alam (2004) were inputted into the PHREEQC database (under EXCHANGE_SPECIES block ) and are exemplified in equations 32-34.

For instance, the exchange equation $\mathrm{Hg}^{2+} / \mathrm{Na}^{+}$was obtained from Khan and Alam (2004):

$$
\begin{aligned}
\mathrm{Hg}^{2+}+2 \mathrm{Na}-\mathrm{X} \leftrightarrow \mathrm{Hg}-\mathrm{X}_{2}+2 \mathrm{Na}^{+} \\
\mathrm{K}_{\mathrm{Hg} / \mathrm{Na}}=0.04, \log \left(\mathrm{K}_{\mathrm{Hg} / \mathrm{Na}}\right)=-1.39
\end{aligned}
$$

One half-reaction for $\mathrm{Na}^{+}$defined in PHREEQC is:

$$
\begin{gathered}
N a^{+}+X^{-} \leftrightarrow N a-X \\
\log \mathrm{K}=0
\end{gathered}
$$

Thus the second half-reaction of equation 32 is:

$$
\begin{gathered}
H g^{2+}+2 X^{-} \leftrightarrow H g-X_{2} \\
\text { Log } \mathrm{K}=-1.39
\end{gathered}
$$


The completed ion exchange between $\mathrm{Hg}^{2+}$ and other cations and their exchange coefficients are shown in Appendix C.

\subsubsection{Hg Surface Complexation}

Similarly to aqueous and ion exchange species, the master surface species must be defined under the SURFACE_MASTER_SPECIES block. The PHREEQC database contains the surface species of $\mathrm{Fe}(\mathrm{OH})_{3}$ for weak (Hfo_w) and strong (Hfo_s) sites with the hydroxide with $\equiv \mathrm{Hfo} \_$wOH and $\equiv \mathrm{Hfo} \_$sOH representing its surface master species. The new surface species data collected from the literature are Fe-Oxide (三Feox),

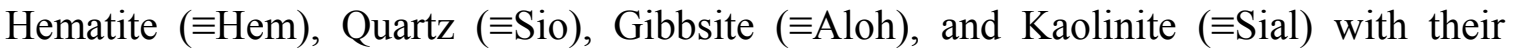
hydroxide group representing their master species.

\begin{tabular}{|c|c|}
\hline \multicolumn{2}{|c|}{ SURFACE_MASTER_SPECIES } \\
\hline Element name & Master Species \\
\hline$\equiv$ Hfo_w & $\equiv \mathrm{Hfo} \_$wOH \\
\hline$\equiv$ Hfo_s & $\equiv \mathrm{Hfo} \_\mathrm{sOH}$ \\
\hline$\equiv$ Amo & $\equiv$ Amo_OH \\
\hline$\equiv$ Hem & $\equiv$ Hem_OH \\
\hline$\equiv \mathrm{Sio}$ & $\equiv$ Sio_OH \\
\hline$\equiv$ Aloh & $\equiv$ Aloh_OH \\
\hline$\equiv$ Sial & $\equiv$ Sial_OH \\
\hline
\end{tabular}

The surface species and $\log \mathrm{K}$ data can be defined under the SURFACE_SPECIES block. 
Under the SURFACE block, the surface name, number sites, specific area per gram $\left(\mathrm{m}^{2} / \mathrm{g}\right)$, and mass $(\mathrm{g})$ of the surface species must be defined. These data were obtained from the literature except the surface mass, which can be defined by the modeler. An example of the input file for $\mathrm{Fe}(\mathrm{OH})_{3}$ and Quartz surface species that are defined under the SURFACE block is shown below.

\section{SURFACE}

\begin{tabular}{|c|c|c|c|}
\hline Surface Name & $\begin{array}{l}\text { Number of Surface Site } \\
\text { (mole) }\end{array}$ & $\begin{array}{l}\text { Surface Area } \\
\left(\mathrm{m}^{2} / \mathrm{g}\right)\end{array}$ & $\begin{array}{l}\text { Surface Mass } \\
\text { (g) }\end{array}$ \\
\hline$\equiv$ Hfo_w & 0.2 & 600 & Modeler defined \\
\hline$\equiv$ Aloh & $1.023 \times 10^{-4}$ & 4.15 & Modeler defined \\
\hline
\end{tabular}

The completed new surface species data that was added into the PHREEQC database are shown in Appendix C.

\subsection{Hg Thermodynamic Properties}

\subsubsection{Hg Reaction Equilibrium and Solubility Constants}

The Hg speciation in aquatic environments is governed by a number of factors: $\mathrm{pH}$, temperature, $\mathrm{DO}$, presence of inorganic and organic ligands, among others. The existing Hg database in PHREEQC, which was obtained and validated by a vast number of studies (Parkhurst and Appelo, 1999), is shown in Table 2 for Hg reactions and Table 3 for Hg solubility reactions. 
Table 2 The reaction equilibrium constants of $\mathrm{Hg}$ available in PHREEQC (Parkhurst and Appelo, 1999)

\begin{tabular}{|c|c|}
\hline Reactions & $\log K$ \\
\hline $\mathrm{Hg}(\mathrm{OH})_{2}+\mathrm{Cl}^{-}+2 \mathrm{H}^{+}=\mathrm{HgCl}^{+}+2 \mathrm{H}_{2} \mathrm{O}$ & 12.85 \\
\hline $\mathrm{Hg}(\mathrm{OH})_{2}+2 \mathrm{Cl}^{-}+2 \mathrm{H}^{+}=\mathrm{HgCl}_{2}+2 \mathrm{H}_{2} \mathrm{O}$ & 19.22 \\
\hline $\mathrm{Hg}(\mathrm{OH})_{2}+3 \mathrm{Cl}^{-}+2 \mathrm{H}^{+}=\mathrm{HgCl}_{3}^{-}+2 \mathrm{H}_{2} \mathrm{O}$ & 20.12 \\
\hline $\mathrm{Hg}(\mathrm{OH})_{2}+4 \mathrm{Cl}^{-}+2 \mathrm{H}^{+}=\mathrm{HgCl}_{4}^{2-}+2 \mathrm{H}_{2} \mathrm{O}$ & 20.53 \\
\hline $\mathrm{Hg}(\mathrm{OH})_{2}+\mathrm{Cl}^{-}+\mathrm{H}^{+}=\mathrm{HgClOH}+\mathrm{H}_{2} \mathrm{O}$ & 9.31 \\
\hline $\mathrm{Hg}(\mathrm{OH})_{2}+\mathrm{F}^{-}+2 \mathrm{H}^{+}=\mathrm{HgF}^{+}+2 \mathrm{H}_{2} \mathrm{O}$ & 8.08 \\
\hline $\mathrm{Hg}(\mathrm{OH})_{2}+\mathrm{I}^{-}+2 \mathrm{H}^{+}=\mathrm{HgI}^{+}+2 \mathrm{H}_{2} \mathrm{O}$ & 18.89 \\
\hline $\mathrm{Hg}(\mathrm{OH})_{2}+2 \mathrm{I}^{-}+2 \mathrm{H}^{+}=\mathrm{HgI}_{2}+2 \mathrm{H}_{2} \mathrm{O}$ & 30.10 \\
\hline $\mathrm{Hg}(\mathrm{OH})_{2}+3 \mathrm{I}^{-}+2 \mathrm{H}^{+}=\mathrm{HgI}_{3}^{-}+2 \mathrm{H}_{2} \mathrm{O}$ & 33.79 \\
\hline $\mathrm{Hg}(\mathrm{OH})_{2}+4 \mathrm{I}^{-}+2 \mathrm{H}^{+}=\mathrm{HgI}_{4}{ }^{2-}+2 \mathrm{H}_{2} \mathrm{O}$ & 35.78 \\
\hline $\mathrm{Hg}(\mathrm{OH})_{2}+\mathrm{H}^{+}=\mathrm{HgOH}+\mathrm{H}_{2} \mathrm{O}$ & 2.70 \\
\hline $\mathrm{Hg}(\mathrm{OH})_{2}+\mathrm{H}_{2} \mathrm{O}=\mathrm{Hg}(\mathrm{OH})_{3}{ }^{-}+\mathrm{H}^{+}$ & 15.00 \\
\hline $\mathrm{Hg}(\mathrm{OH})_{2}+2 \mathrm{HS}^{-}=\mathrm{HgS}_{2}{ }^{2-}+2 \mathrm{H}_{2} \mathrm{O}$ & 31.24 \\
\hline $\mathrm{Hg}(\mathrm{OH})_{2}+2 \mathrm{HS}^{-}+2 \mathrm{H}^{+}=\mathrm{Hg}(\mathrm{HS})_{2}+2 \mathrm{H}_{2} \mathrm{O}$ & 43.82 \\
\hline $\mathrm{Hg}(\mathrm{OH})_{2}+\mathrm{SO}_{4}{ }^{2-}+2 \mathrm{H}^{+}=\mathrm{HgSO}_{4}+2 \mathrm{H}_{2} \mathrm{O}$ & 7.49 \\
\hline
\end{tabular}

Table $3 \mathrm{Hg}$ solubility reaction equilibrium constants available in PHREEQC (Parkhurst and Appelo, 1999)

\begin{tabular}{|lcc|}
\multicolumn{1}{|c}{ Solubility Reactions } & Log K & $\Delta \mathbf{H}(\mathbf{k J})$ \\
\hline $\mathrm{HgS}+2 \mathrm{H}_{2} \mathrm{O}=\mathrm{Hg}(\mathrm{OH})_{2}+\mathrm{H}^{+}+\mathrm{HS}^{-}$ & -45.69 & 253.76 \\
\hline $\mathrm{HgS}+2 \mathrm{H}_{2} \mathrm{O}=\mathrm{Hg}(\mathrm{OH})_{2}+\mathrm{H}^{+}+\mathrm{HS}^{-}$ & -45.09 & 253.72 \\
\hline $\mathrm{HgO}+\mathrm{H}_{2} \mathrm{O}=\mathrm{Hg}(\mathrm{OH})_{2}$ & -3.64 & -38.9 \\
\hline $\mathrm{Hg}(\mathrm{OH})_{2}=\mathrm{Hg}(\mathrm{OH})_{2}$ & -3.49 & -0 \\
\hline $\mathrm{HgCl}_{2}+2 \mathrm{H}_{2} \mathrm{O}=\mathrm{Hg}(\mathrm{OH})_{2}+2 \mathrm{Cl}^{-}+2 \mathrm{H}^{+}$ & -21.26 & 107.82 \\
\hline
\end{tabular}


However, as it was mentioned earlier, the existing $\mathrm{Hg}$ databases in PHREEQC are limited and thus inadequate to effectively represent all possible $\mathrm{Hg}$ speciation that may occur in an aqueous system. Therefore, the aim of this literature review was to obtain the thermodynamic properties of $\mathrm{Hg}$ (speciation, sorption process, etc.). These properties were added into the PHREEQC database. Then the model predictions were confirmed by simulating and comparing the $\mathrm{Hg}$ speciation to experimental reported results that were identified in the literature. The comparison between the literature results and those estimated by the enhanced database and model produced quite comparable results thus confirming the prediction capability of PHREEQC.

An illustration of the procedure is the case of the experimental work of Gårdfeldt et al. (2003), who conducted experiments to study the various mercuric acetate complexes in equilibrium at various $\mathrm{pH}$ values. The mercuric acetate species and their thermodynamic properties from Gårdfeldt et al. (2003) study (Table 4) were added to the enhanced PHREEQC database.

Table 4 Thermodynamic propertied of Hg-Acetate obtained from Gårdfeldt et al. (2003)

\begin{tabular}{|ccc|}
\hline Mercury species & \multicolumn{1}{c|}{ Reactions } & Log K \\
\hline$\left[\mathrm{Hg}\left(\mathrm{CH}_{3} \mathrm{COO}\right)\right]^{+}$ & $\mathrm{Hg}^{2+}+\mathrm{CH}_{3} \mathrm{COO}^{-}=\left[\mathrm{Hg}\left(\mathrm{CH}_{3} \mathrm{COO}\right)\right]^{+}$ & 4.3 \\
\hline $\mathrm{Hg}\left(\mathrm{CH}_{3} \mathrm{COO}\right)_{2}$ & $\mathrm{Hg}^{2+}+2 \mathrm{CH}_{3} \mathrm{COO}^{-}=\mathrm{Hg}\left(\mathrm{CH}_{3} \mathrm{COO}\right)_{2}$ & 7.0 \\
\hline$\left[\mathrm{Hg}\left(\mathrm{CH}_{3} \mathrm{COO}\right)_{3}\right]^{-}$ & $\mathrm{Hg}^{2+}+3 \mathrm{CH}_{3} \mathrm{COO}^{-}=\left[\mathrm{Hg}\left(\mathrm{CH}_{3} \mathrm{COO}\right)_{3}\right]^{-}$ & 13.3 \\
\hline$\left[\mathrm{Hg}\left(\mathrm{CH}_{3} \mathrm{COO}\right)_{3}\right]^{2-}$ & $\mathrm{Hg}^{2+}+4 \mathrm{CH}_{3} \mathrm{COO}^{-}=\left[\mathrm{Hg}\left(\mathrm{CH}_{3} \mathrm{COO}\right)_{4}\right]^{2-}$ & 17.1 \\
\hline
\end{tabular}

The results obtained from Gårdfeldt's experimental works are shown in Figure 1. 

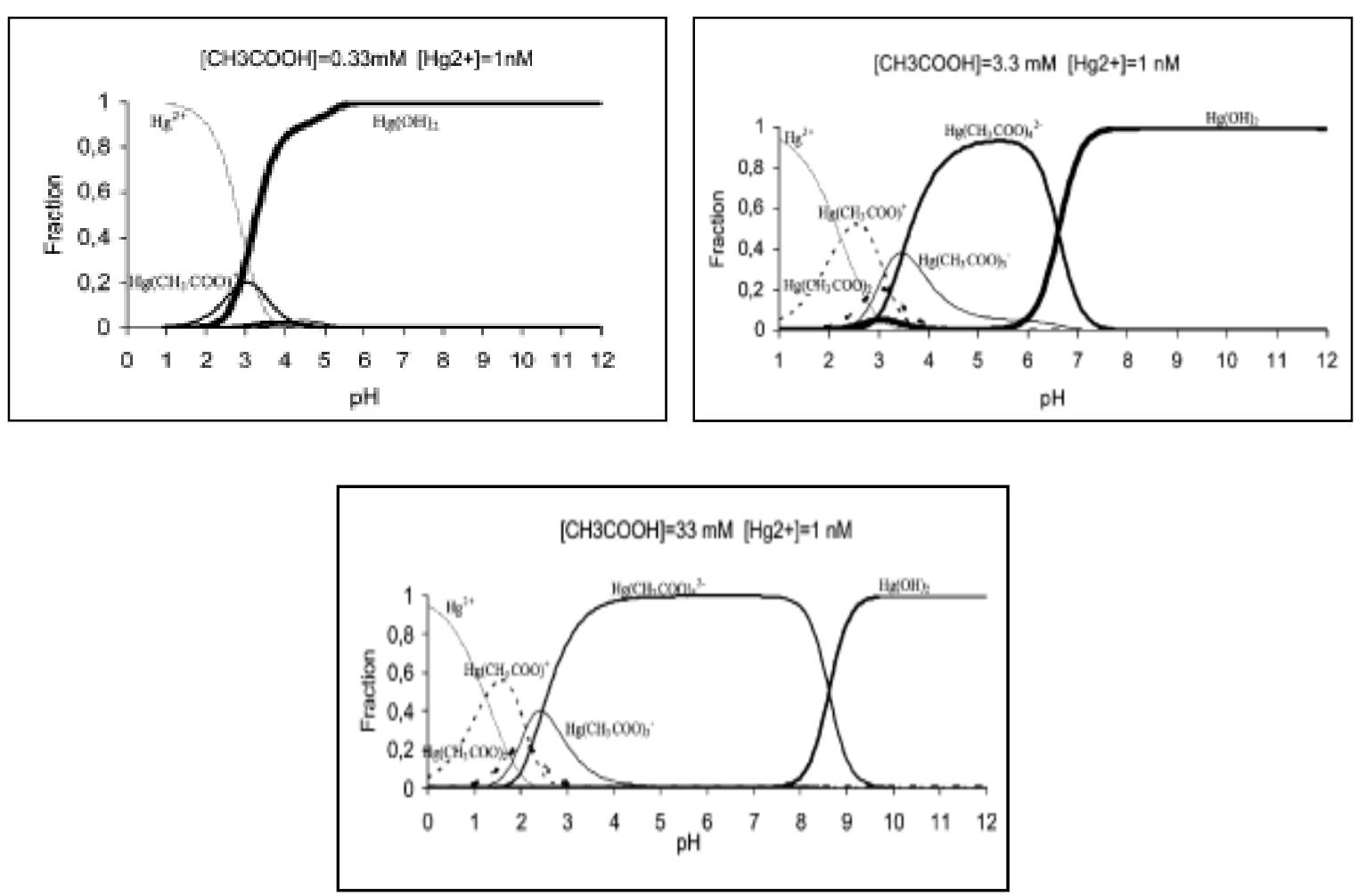

Figure 1 Gårdfeldt et al. (2003) study of mercuric acetate complexes over a wide pH

Gårdfeldt et al. (2001) conducted experimental work to study the complexation of $\mathrm{MeHg}$ at various $\mathrm{pH}$ using phosphate buffer. They reported that the complexation of $\mathrm{MeHg}$ obtained from their experimental work (Figure 2) was quite consistent with hand calculations using the thermodynamic data in Table 5. Consequently, the thermodynamic data of Table 5 were also added to enhance the database of the PHREEQC model. 
Table 5 Hg reaction equilibrium and solubility constants (Gårdfeldt et al., 2001)

\begin{tabular}{|c|c|c|}
\hline Reactions & $\log K$ & References \\
\hline $\mathrm{CH}_{3} \mathrm{Hg}^{+}+\mathrm{HPO}_{4}{ }^{2-}=\left(\mathrm{CH}_{3} \mathrm{Hg} \mathrm{HPO}_{4}\right)^{-}$ & 5.0 & $\begin{array}{l}\text { Schwarzenbach and } \\
\text { Schellenberg (1965) }\end{array}$ \\
\hline $\mathrm{CH}_{3} \mathrm{Hg}^{+}+\mathrm{OH}^{-}=\mathrm{CH}_{3} \mathrm{Hg} \mathrm{OH}$ & 9.4 & $\begin{array}{l}\text { Schwarzenbach and } \\
\text { Schellenberg (1965) }\end{array}$ \\
\hline $2 \mathrm{CH}_{3} \mathrm{Hg}^{+}+\mathrm{OH}^{-}=\left[\left(\mathrm{CH}_{3} \mathrm{Hg}\right)_{2} \mathrm{OH}\right]^{+}$ & 2.4 & Libich and Robenstein (1973) \\
\hline $\mathrm{Hg}^{2+}+\mathrm{OH}^{-}=\mathrm{HgOH}^{+}$ & 10.6 & Dyrssen and Tyrell (1961) \\
\hline $\mathrm{Hg}^{2+}+2 \mathrm{OH}^{-}=\mathrm{Hg}(\mathrm{OH})_{2}$ & 21.9 & Dyrssen and Tyrell (1961) \\
\hline $\mathrm{Hg}^{2+}+3 \mathrm{OH}^{-}=\left(\mathrm{Hg}(\mathrm{OH})_{3}\right)^{-}$ & 20.9 & Garett and Hirschler (1938) \\
\hline $2 \mathrm{Hg}^{2+}+\mathrm{OH}^{-}=\left(\mathrm{Hg}_{2} \mathrm{OH}\right)^{+}$ & 10.7 & Ahlberg (1962) \\
\hline $\mathrm{Hg}^{2+}+\mathrm{HPO}_{4}{ }^{3-}=\left(\mathrm{Hg} \mathrm{HPO}_{4}\right)^{-}$ & 9.5 & Quarfort-Dahlman (1975) \\
\hline $3 \mathrm{Hg}^{2+}+\mathrm{PO}_{4}^{3-}+3 \mathrm{OH}-=(\mathrm{HgOH})_{3} \mathrm{PO}_{4}(\mathrm{~s})$ & 21.4 & Quarfort-Dahlman (1975) \\
\hline $\mathrm{Hg}^{2+}+2 \mathrm{OH}^{-}=\mathrm{Hg}(\mathrm{OH})_{2}(\mathrm{~s})$ & 25.4 & Dyrssen and Tyrell (1961) \\
\hline $3 \mathrm{Hg}^{2+}+\mathrm{PO}_{4}{ }^{3-}=\mathrm{Hg}_{3}\left(\mathrm{PO}_{4}\right)_{2}(\mathrm{~s})$ & 49.4 & Gårdfeldt et al. (2003) \\
\hline $\mathrm{Hg}^{2+}+\mathrm{HPO}_{4}^{2-}=\mathrm{HgHPO}_{4}(\mathrm{~s})$ & 13.1 & Haitzer et al. (2002) \\
\hline $\mathrm{Hg}^{2+}+\mathrm{H}_{2} \mathrm{O}=\mathrm{HgO}(\mathrm{s})+2 \mathrm{H}^{+}$ & -2.45 & Hietanen and Hogfeldt (1976) \\
\hline
\end{tabular}




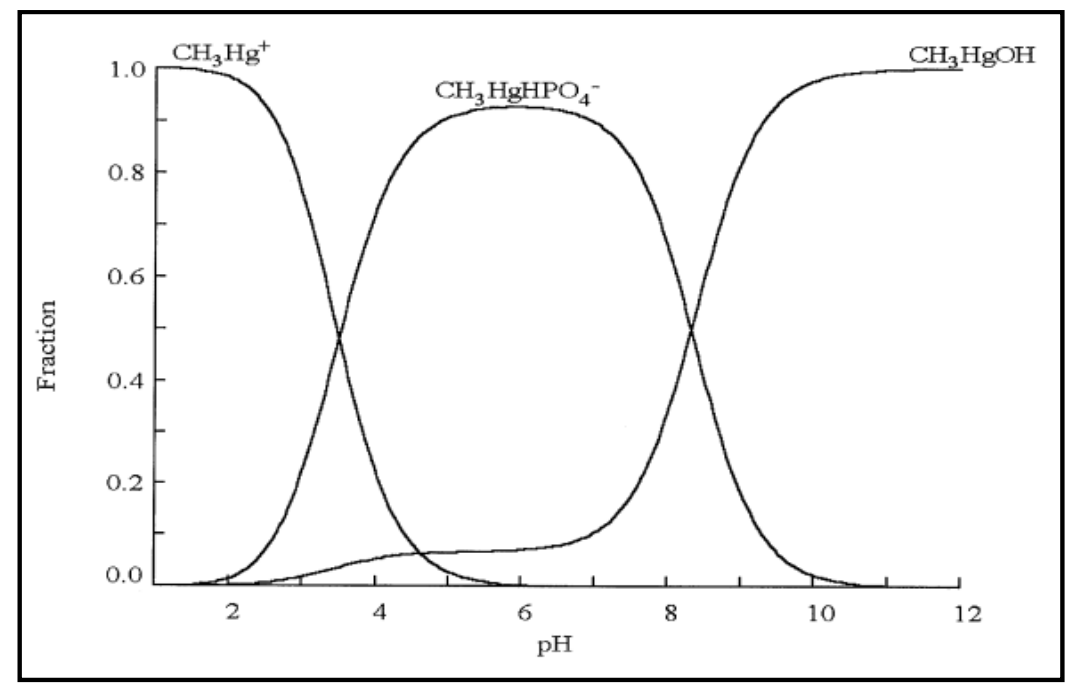

Figure $2 \mathrm{MeHg}$ species as function of pH; Gårdfeldt et al. (2001)

\subsubsection{Hg-DOM Reaction Equilibrium Constants}

$\mathrm{Hg}(\mathrm{II})$ is generally bound to the acid site of organic matter (i.e., carboxylic acid, phenols, ammonium ions, alcohols, and thiols) (Ravichandran, 2004); carboxylic acid and phenol groups are the acidic functional groups that contain up to $90 \%$ of DOM (dissolved organic matter). However, mercury is found to preferentially bind to thiol groups (RS ${ }^{-}$, which constitute a small percentage of DOM compared to oxygen or nitrogen-containing functional groups $\left(\mathrm{RO}^{-}\right.$and $\left.\mathrm{RN}^{-}\right)$. The study of Xia et al. (1999) also confirmed that $\mathrm{Hg}(\mathrm{II})$ preferably binds to $\mathrm{RS}^{-}$groups over $\mathrm{RO}^{-}$in DOM. The relationship between DOM and reduced sulfur concentration in DOM (equation 1) was proposed by Dong et al. (2010). Thus, concentration of reduced sulfur in DOM can be estimated using equation 35.

$$
[\text { Sred }]=[\mathrm{DOM}] \times \mathrm{F}_{1} \times \mathrm{F}_{2} / \mathrm{W}
$$


where:

[Sred] is the concentration of reduced sulfur in DOM

$F_{1}$ is fraction of total sulfur content in DOM

$\mathrm{F}_{2}$ is fraction of reduced sulfur

$\mathrm{W}$ is atomic weight of sulfur

Ravichandran (2004) reported that the total sulfur content in DOM was found to be approximately $1 \%(\mathrm{wt} \%$ of DOM), while reduced sulfur was $50 \%$ of total sulfur $(\mathrm{wt} \%$ of total sulfur). However, not all of reduced sulfur is reactive for binding with $\mathrm{Hg}(\mathrm{II})$. Amirbahman et al. (2002) and Haitzer et al. (2002 and 2003) reported that only a small fraction, approximately $2 \%$, of reduced sulfur, was available for binding with $\mathrm{Hg}(\mathrm{II})$. Moreover, the study of Skyllberg et al. (2006), which used EXAFS, an Extended X-Ray Absorption Fine Structure, to study the complexation of $\mathrm{Hg}(\mathrm{II})$ in soil organic matter, indicated that $20-30 \%$ of reduced sulfur is involved in the Hg-Thiol group. Furthermore, these studies indicate that around $2-30 \%$ of reduced sulfur content in DOM is reactive and is available for $\mathrm{Hg}$ (II) binding. The logs of stability constants (log $\mathrm{K}$ ) between $\mathrm{Hg}$ and $\mathrm{RS}^{-}$were reported in a wide range $(\log \mathrm{K}=20-40)$, the actual value depending on the conditions of the experimental study. The reaction constants of $\mathrm{Hg}-\mathrm{RS}^{-}, \mathrm{Hg}-\mathrm{RO}^{-}$, and $\mathrm{Hg}_{-} \mathrm{RN}^{-}$are shown in Table 6. 
Table 6 Reaction equilibrium constants of $\mathrm{Hg}$ and reactive functional groups in DOM [thiol group ( $\left.\mathrm{RS}^{-}\right)$, oxygen- or nitrogen-containing functional group $\left(\mathrm{RO}^{-}\right.$and $\left.\mathrm{RN}^{-}\right)$]

\begin{tabular}{|c|c|c|}
\hline Type of DOM & Reaction & $\log K$ \\
\hline \multirow{3}{*}{$\begin{array}{l}\text { DOM isolates from Florida Everglades (Haitzer et } \\
\text { al., 2003) }\end{array}$} & $\mathrm{Hg}^{2+}+\mathrm{RS}^{-}+\mathrm{RX}^{-}=\mathrm{Hg}(\mathrm{RS})(\mathrm{RX})$ & $28.7 \pm 0.1$ \\
\hline & $\mathrm{RXH}=\mathrm{RS}^{-}+\mathrm{H}^{+}(\mathrm{X}=\mathrm{O}, \mathrm{N}, \mathrm{S})$ & -6.3 \\
\hline & $\mathrm{SRH}=\mathrm{RS}^{-}+\mathrm{H}^{+}$ & -10.3 \\
\hline \multirow{2}{*}{$\begin{array}{l}\text { DOM from California natural waters (Black et al., } \\
\text { 2007) }\end{array}$} & $\mathrm{Hg}^{2+}+\mathrm{RS}^{-}=\mathrm{Hg}(\mathrm{RS})^{+}$ & $29.9-33.5$ \\
\hline & $\mathrm{SRH}=\mathrm{RS}^{-}+\mathrm{H}^{+}$ & -9.96 \\
\hline \multirow[b]{2}{*}{ DOM from Texas estuarine (Han and Gill, 2005) } & $\mathrm{Hg}^{2+}+\mathrm{RS}^{-}=\mathrm{Hg}(\mathrm{RS})^{+}$ & $26.1-26.9$ \\
\hline & $\mathrm{SRH}=\mathrm{RS}^{-}+\mathrm{H}^{+}$ & -10 \\
\hline $\begin{array}{l}\text { DOM from fresh and sea waters (Lamborg et al., } \\
\text { 2003) }\end{array}$ & $\mathrm{Hg}^{2+}+\mathrm{RS}^{-}=\mathrm{Hg}(\mathrm{RS})^{+}$ & $21-24$ \\
\hline \multirow[b]{2}{*}{$\begin{array}{l}\text { DOM isolates from Florida Everglades (Haitzer et } \\
\text { al., 2002) }\end{array}$} & $\mathrm{Hg}^{2+}+\mathrm{RS}^{-}=\mathrm{Hg}(\mathrm{RS})^{+}$ & 28.5 \\
\hline & $\mathrm{RSH}=\mathrm{RS}^{-}+\mathrm{H}^{+}$ & -10 \\
\hline \multirow[b]{2}{*}{$\begin{array}{l}\text { Peats and DOM from Florida Everglades (Drexel et } \\
\text { al., 2002) }\end{array}$} & $\mathrm{Hg}^{2+}+\mathrm{RS}^{-}=\mathrm{Hg}(\mathrm{RS})^{+}$ & $25.8-27.2$ \\
\hline & $\mathrm{RSH}=\mathrm{RS}^{-}+\mathrm{H}^{+}$ & -10 \\
\hline \multirow[b]{2}{*}{$\begin{array}{l}\text { DOM isolates from Florida Everglades (Benoit et } \\
\text { al., 2001) }\end{array}$} & $\mathrm{Hg}^{2+}+\mathrm{RS}^{-}=\mathrm{Hg}(\mathrm{RS})^{+}$ & $20.6-23.8$ \\
\hline & $\mathrm{RSH}=\mathrm{RS}^{-}+\mathrm{H}^{+}$ & -10 \\
\hline
\end{tabular}

\subsubsection{Hg Ion Exchange}

Ion exchange is one of the important mechanisms that play a major role in the transport of $\mathrm{Hg}$ in aquatic environments. The difference between sorption and exchange mechanisms is that "sorption" indicates that the chemical is taken up into the solid, while "exchange" involves replacement of one chemical for another one at the solid surface (Appelo and Postma, 2010). The ion exchange for all solid surfaces in aquatic 
environments is related to the soil Cation Exchange Capacity (CEC) and ion exchange coefficients.

\subsubsection{CEC of common soil and sediment materials}

CEC indicates the amount of cations that can be attached to the negative charge sites of soil. CEC is commonly expressed as milli-equivalent of hydrogen $\left(\mathrm{H}^{+}\right)$per $100 \mathrm{~g}$ of dry soil or meq/ $100 \mathrm{~g}_{\text {soil }}$. CEC values of common soils and sediment materials reported by several researchers (Appelo and Postma, 2005; Bergaya and Vayer, 1997) are shown in Table 7.

Table 7 CEC of common soil and sediment materials (Appelo and Postma, 2005; Bergaya and Vayer, 1997)

\begin{tabular}{|cc|}
\hline Soil and Sediment Materials & CEC \\
& $\mathbf{~ m e q} / \mathbf{k g}$ \\
\hline Allophane & $\sim 700$ \\
\hline Bentonite & $1000-1200$ \\
\hline Glauconite & $50-400$ \\
\hline Goethite & $\sim 800$ \\
\hline Halloysite & $50-100$ \\
\hline Hematite & $\sim 700$ \\
\hline Illite & $200-500$ \\
\hline Kaolinite & $30-150$ \\
\hline Montmorillonite & $800-1200$ \\
\hline Quartz & $6-53$ \\
\hline Shale & $100-410$ \\
\hline Vermiculite & $1000-2000$ \\
\hline
\end{tabular}




\subsubsection{2 $\mathrm{Hg}(\mathrm{II})$ ion exchange coefficients}

The ion exchange coefficient is a coefficient that defines the amount of one chemical that replaces another chemical on the sediment's exchange site. For the ion exchange reaction of $\mathrm{Hg}(\mathrm{II})$ for any cation, $I^{i}$, can be written as equation 36 , while its ion exchange coefficient can be obtained from the law of mass action as shown in equation 37.

$$
\begin{aligned}
& \text { Reaction: } \quad 1 / 2 H^{2+}+1 / i \cdot I-X_{i} \leftrightarrow 1 / 2 \cdot H g-X_{2}+1 / I^{i+} \\
& \text { Ion exchange coefficient: } \quad K_{H g / I}=\frac{[H g-X]^{1 / 2}\left[I^{i+}\right]^{1 / i}}{\left[I-X_{i}\right]^{1 / i}\left[H g^{2+}\right]^{1 / 2}}
\end{aligned}
$$

where $\mathrm{X}$ is the exchange sites, and the square brackets in the equation represent the activities. The exchange coefficients are commonly used and their values depend upon the type of exchanger present in the soil.

The PHREEQC database contains ion exchange coefficients of various elements that are related to $\mathrm{Na}^{+}$. This is because $\mathrm{Na}^{+}$is a common ion that is contained in soils. The existing PHREEQC database is shown in Table 8; $\mathrm{M}$ in Table 8 represents any cation, while the numbers in parentheses are the given ranges that present many measurements from different soils and for different clay minerals (Appelo and Postma, 2005; Bruggenwert and Kamphorst, 1979; Parkhurst and Appelo, 1999).

Although, many ion exchange coefficients that relate to $\mathrm{Na}$ are provided in the PHREEQC database, there is no data available for $\mathrm{Hg}$. 
Khan and Alam (2004) reported the ion exchange coefficients of $\mathrm{Hg}(\mathrm{II})$ for various ions as shown in Table 9. The ion exchange coefficients provided in Table 9 were then added and used in the PHREEQC database by converting them in values relative to $\mathrm{Na}^{+}$. The exchange coefficients between other pairs of cations can be obtained by combining two reactions.

Table 8 PHREEQC existing database of ion exchange coefficients relative to $\mathrm{Na}^{+}$ (Appelo and Postma, 2005; Bruggenwert and Kamphorst, 1979; Parkhurst and Appelo, 1999)

\begin{tabular}{|cccc|}
\hline Ions & $\begin{array}{c}\text { Ion exchange } \\
\text { coefficients }\end{array}$ & Ions & $\begin{array}{c}\text { Ion exchange } \\
\text { coefficients }\end{array}$ \\
\hline $\mathrm{Ki}^{+}$ & $1.2(0.95-1.2)$ & $\mathrm{Mn}^{3+}$ & 0.55 \\
\hline $\mathrm{K}^{+}$ & $0.2(0.15-0.25)$ & $\mathrm{Ke}^{2+}$ & 0.6 \\
\hline $\mathrm{NH}_{4}{ }^{+}$ & $0.25(0.2-0.3)$ & $\mathrm{Co}^{2+}$ & 0.6 \\
\hline $\mathrm{Rb}^{+}$ & 0.1 & $\mathrm{Ni}^{2+}$ & 0.5 \\
\hline $\mathrm{Cs}^{+}$ & 0.08 & $\mathrm{Cu}^{2+}$ & 0.5 \\
\hline $\mathrm{Mg}^{2+}$ & $0.5(0.4-0.6)$ & $\mathrm{Zn}^{2+}$ & $0.4(0.3-0.6)$ \\
\hline $\mathrm{Ca}^{2+}$ & $0.4(0.3-0.6)$ & $\mathrm{Cd}^{2+}$ & $0.4(0.3-0.6)$ \\
\hline $\mathrm{Sr}^{2+}$ & $0.35(0.3-0.6)$ & $\mathrm{Pb}^{2+}$ & 0.3 \\
\hline $\mathrm{Ba}^{2+}$ & $0.35(0.2-0.5)$ & $\mathrm{Al}^{2+}$ & $0.7(0.5-0.9)$ \\
\hline
\end{tabular}


Table 9 Ion exchange coefficients for various ions related to $\mathrm{Hg}(\mathrm{II})$ (Khan and Alam, 2004)

\begin{tabular}{|ll|} 
& Ion exchange coefficients \\
\hline Ions & $\mathbf{K}_{\mathbf{H g} / \mathbf{M}}$ \\
\hline $\mathrm{Na}^{+}$ & 0.04 \\
\hline $\mathrm{K}^{+}$ & 0.03 \\
\hline $\mathrm{Mg}^{2+}$ & 0.02 \\
\hline $\mathrm{Co}^{2+}$ & 0.04 \\
\hline $\mathrm{Ni}^{2+}$ & 0.02 \\
\hline $\mathrm{Cu}^{2+}$ & 0.03 \\
\hline $\mathrm{Mn}^{2+}$ & 0.03 \\
\hline $\mathrm{Zn}^{2+}$ & 0.02 \\
\hline $\mathrm{Pb}^{2+}$ & 0.07 \\
\hline $\mathrm{Al}^{3+}$ & 0.01 \\
\hline $\mathrm{Fe}^{3+}$ & 0.05 \\
\hline
\end{tabular}

\subsubsection{Hg Surface Complexation}

4.2.4.1 Surface complexation on iron oxide minerals

PHREEQC uses the surface complexation model that was proposed by Dzombak and Morel (1990) to calculate the sorption of metals onto the surface of minerals. Dzombak and Morel (1990) have obtained the database for surface complexation on hydrous ferric oxide or ferrihydrite $\left[\mathrm{Fe}(\mathrm{OH})_{3}\right]$ (Dzombak and Morel, 1990; Schlüter, 1995; Schlüter and Gäth 1997). Dzombak and Morel's complexation reaction model was defined for two sites on ferrihydrite, a weak site ( $\equiv$ Hfo_sOH) and a strong site 
(三Hfo_wOH). The equilibrium constants for surface complexation of $\mathrm{Hg}$ are shown in Table 10 (Dzombak and Morel, 1990; Yasunaga and Ikeda, 1986; Hayes and Leckie, 1986). The surface complexation for other iron oxide minerals (Goethite, Amorphous FeOxide, and Hematite) can also be calculated using Dzombak and Morel's model. Nevertheless, the sorption capability of the minerals mainly depends on their surface area properties (Arias et al., 2004; Miretzky et al., 2005; Martell and Smith, 2001) (Table 11).

Table 10 Dzombak and Morel (1990)'s sorption-reaction constant database for Hg

\begin{tabular}{|c|c|}
\hline Reactions & $\log K$ \\
\hline$\equiv \mathrm{Hfo} \_\mathrm{sOH}+\mathrm{Hg}(\mathrm{OH})_{2}+\mathrm{H}^{+}=\equiv \mathrm{Hfo}_{-} \mathrm{sOHg}{ }^{+}+2 \mathrm{H}_{2} \mathrm{O}$ & 13.95 \\
\hline$\equiv \mathrm{Hfo} \_w O H+\mathrm{Hg}(\mathrm{OH})_{2}+\mathrm{H}^{+}=\equiv \mathrm{Hfo} \_w O H g^{+}+2 \mathrm{H}_{2} \mathrm{O}$ & 12.64 \\
\hline
\end{tabular}

Table 11 Surface property of iron oxide minerals (Arias et al., 2004; Miretzky et al., 2005; Martell and Smith, 2001)

\begin{tabular}{|lcccc|}
\hline \multicolumn{1}{|c}{ Iron Oxides } & $\begin{array}{c}\text { Weak Sites } \\
(\mathbf{m o l} / \mathbf{m o l ~ F e})\end{array}$ & $\begin{array}{c}\text { Strong Sites } \\
(\mathbf{m o l} / \mathbf{m o l ~ F e})\end{array}$ & $\begin{array}{c}\text { Surface } \\
\text { Area }\left(\mathbf{m}^{2} / \mathbf{g}\right)\end{array}$ & $\begin{array}{c}\text { Point of } \\
\text { Zero } \\
\text { Charge } \mathbf{~ p H}\end{array}$ \\
\hline Ferrihydrite & 0.2 & 0.005 & 600 & 8.11 \\
\hline $\begin{array}{l}\text { Amorphous Fe- } \\
\text { Oxide }\end{array}$ & 0.075 & 0.0018 & 222.7 & 7.23 \\
\hline Goethite & 0.02 & 0.0005 & 63.1 & 8.82 \\
\hline Hematite & 0.003 & 0.00009 & 10.9 & 8.5 \\
\hline
\end{tabular}

\subsubsection{Surface complexation on quartz and gibbsite}

Sarkar et al. (1999) studied and conducted the experiments on the adsorption of $\mathrm{Hg}(\mathrm{II})$ on the surface of quartz $\left(\mathrm{SiO}_{2}\right)$ and gibbsite $\left[\mathrm{Al}(\mathrm{OH})_{3}\right]$, using the solid properties (Table 12) documented in various studies (Elliott and Huang, 1981; Meng and Letterman, 
1993; Riese, 1982; Singh and Mattigod, 1992). The surface complexation and the intrinsic equilibrium constants ( $\left.\log \mathrm{K}_{\text {int }}\right)$ for quartz (三Sio) and gibbsite (三Aloh) used in this study are shown in Tables 13 and 14 respectively.

Table 12 Quartz and gibbsite properties used in Sarkar et al. (1999)

\begin{tabular}{|lcc|}
\multicolumn{1}{|c|}{ Parameter } & Quartz & Gibbsite \\
\hline Surface area, $\mathrm{m}^{2} / \mathrm{g}$ & 4.15 & 3.5 \\
\hline Site density, $\mathrm{n} / \mathrm{m}^{2}$ & 4.5 & 8.0 \\
\hline Total surface sites $\left(\times 10^{-4} \mathrm{~mol} / \mathrm{L}\right)$ & 1.023 & 1.534 \\
\hline
\end{tabular}

Table 13 The surface complexation and the intrinsic equilibrium constants $\left(\log \mathrm{K}_{\text {int }}\right)$ of $\mathrm{Hg}$ (II) adsorption on quartz (三Sio) (Sarkar et al., 1999)

\begin{tabular}{|c|c|}
\hline Parameter & $\log K_{\text {int }}$ \\
\hline$\equiv \mathrm{Sio} \_\mathrm{OH}+\mathrm{H}^{+}=\equiv$ Sio_OH ${ }_{2}^{+}$ & 2.77 \\
\hline$\equiv$ Sio_OH $=\equiv$ Sio_O $\mathrm{O}^{-}+\mathrm{H}^{+}$ & -6.77 \\
\hline$\equiv \mathrm{Sio} \_\mathrm{OH}+\mathrm{Na}^{+}=\equiv \mathrm{Sio} \_\mathrm{Na}^{+}+\mathrm{H}^{+}$ & -6.21 \\
\hline$\equiv \mathrm{Sio} \_\mathrm{OH}+\mathrm{Hg}^{2+}+\mathrm{H}_{2} \mathrm{O}=\equiv \mathrm{Sio} \_\mathrm{OHgOH}+2 \mathrm{H}^{+}$ & -2.19 \\
\hline$\equiv \mathrm{Sio} \_\mathrm{OH}+\mathrm{Hg}^{2+}+2 \mathrm{H}_{2} \mathrm{O}=\equiv \mathrm{Sio} \_\mathrm{OHg}(\mathrm{OH})_{2}{ }^{-}+3 \mathrm{H}^{+}$ & -7.75 \\
\hline 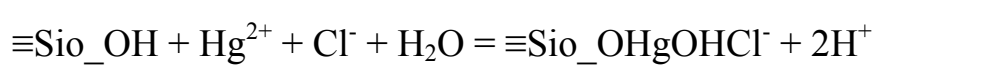 & 2.14 \\
\hline$\equiv$ Sio_OH $+\mathrm{Hg}^{2+}+\mathrm{PO}_{4}{ }^{3-}+\mathrm{H}_{2} \mathrm{O}=\equiv$ Sio_OPO $3 \mathrm{Hg}(\mathrm{OH})_{2}{ }^{2-}+\mathrm{H}^{+}$ & 11.61 \\
\hline
\end{tabular}


Table 14 The surface complexation and the intrinsic equilibrium constants $\left(\log \mathrm{K}_{\text {int }}\right)$ of $\mathrm{Hg}$ (II) adsorption on gibbsite (三Aloh) (Sarkar et al., 1999)

\begin{tabular}{|c|c|}
\hline Parameter & $\log \mathbf{K}_{\text {int }}$ \\
\hline$\equiv$ Aloh_OH $+\mathrm{H}^{+}=\equiv$ Aloh_OH ${ }_{2}^{+}$ & 4.7 \\
\hline$\equiv$ Aloh_OH $=\equiv$ Aloh_O $\mathrm{O}^{-}+\mathrm{H}^{+}$ & -8.7 \\
\hline$\equiv$ Aloh_OH $+\mathrm{Na}^{+}=\equiv$ Aloh_Na ${ }^{+}+\mathrm{H}^{+}$ & -7.0 \\
\hline$\equiv$ Aloh_OH $+\mathrm{Hg}^{2+}+\mathrm{H}_{2} \mathrm{O}=\equiv \mathrm{Aloh} \_\mathrm{OHgOH}+2 \mathrm{H}^{+}$ & -2.6 \\
\hline$\equiv$ Aloh_OH $+\mathrm{Hg}^{2+}+2 \mathrm{H}_{2} \mathrm{O}=\equiv$ Aloh_OHg $(\mathrm{OH})_{2}{ }^{-}+3 \mathrm{H}^{+}$ & -10.2 \\
\hline$\equiv$ Aloh_OH $+\mathrm{Hg}^{2+}+\mathrm{Cl}^{-}+\mathrm{H}_{2} \mathrm{O}=\equiv$ Aloh_OHgOHCl${ }^{-}+2 \mathrm{H}^{+}$ & -0.5 \\
\hline$\equiv$ Aloh_OH $+\mathrm{Hg}^{2+}+\mathrm{PO}_{4}{ }^{3-}+\mathrm{H}_{2} \mathrm{O}=\equiv$ Aloh_OPO $3 \mathrm{Hg}(\mathrm{OH})_{2}{ }^{2-}+\mathrm{H}^{+}$ & 12.5 \\
\hline
\end{tabular}

\subsubsection{Surface complexation on kaolinite}

Zachara et al. (1988) studied the chromate adsorption by kaolinite $\left[\mathrm{Al}_{2} \mathrm{Si}_{2} \mathrm{O}_{5}(\mathrm{OH})_{4}\right]$ and proposed that the ideal structure of kaolinite consists of the

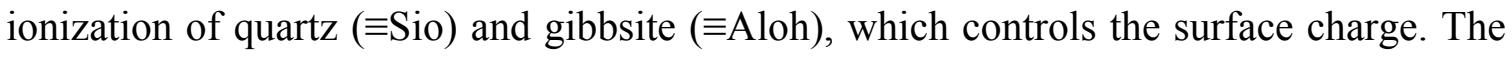
result of their study concluded that the total site density $\left(n_{s}\right)$ of kaolinite consists of equal contribution of $\equiv$ Sio and $\equiv$ Aloh sites (i.e., $n_{s}=[\equiv \mathrm{Sio}]+[\equiv \mathrm{Aloh}]$, and $\left.[\equiv \mathrm{Sio}]=[\equiv \mathrm{Aloh}]\right)$. Sarkar et al. (2000) applied this principle in their model study of adsorption of $\mathrm{Hg}(\mathrm{II})$ by kaolinite, then verified the model results with experimental results. The kaolinite solid properties used in Sarkar et al. (2000) study are shown in Table 15 (Riese, 1982). 
Table 15 Kaolinite properties used in Sarkar et al. (2000)

\begin{tabular}{|lc|}
\multicolumn{1}{|c|}{ Parameter } & Kaolinite \\
\hline Surface $a r e a, \mathrm{~m}^{2} / \mathrm{g}$ & 12.3 \\
\hline Site density, $\mathrm{n} / \mathrm{m}^{2}$ & 6.0 \\
\hline Total surface $\operatorname{sites}\left(\times 10^{-4} \mathrm{~mol} / \mathrm{L}\right)$ & 2.02 \\
\hline
\end{tabular}

The modeling of adsorption of $\mathrm{Hg}$ (II) by kaolinite was conducted, using the surface complexation and the intrinsic equilibrium constants (log $\mathrm{K}_{\text {int }}$ ) of $\mathrm{Hg}(\mathrm{II})$ adsorption onto quartz and gibbsite (see Tables 13 and 14). Sarkar et al. (2000)'s modeling and experimental results were comparable. This supports the Zachara et al. (1988)'s conclusion on the ideal structure of kaolinite. Zhu et al. (2012) studied the transport and interactions of kaolinite and mercury in saturated sand media, using the ideal kaolinite structure proposed by Zachara et al. (1988) and the Hg sorption thermodynamic data on quartz and gibbsite proposed by Sarkar et al. (2000) studies. Their model and experimental results were in good agreement, which confirmed Zachara et al. (1988) and Sarkar et al. (2000) studies.

\subsubsection{Hg(II) surface complexation isotherms}

Sorption isotherm is the relation between sorbed and dissolved solute concentration at a fixed temperature. The Langmuir and the Freundlich isotherms, which are shown in equations 38 and 39, are often used to describe the relation.

$$
\text { Langmuir Isotherm; } \quad \mathrm{S}=\frac{\mathrm{K}_{\mathrm{L}} \mathrm{S}_{\mathrm{m}} \mathrm{C}}{1+\mathrm{K}_{\mathrm{L}} \mathrm{C}}
$$




$$
\text { Freundlich Isotherm; } \quad \mathrm{S}=\mathrm{K}_{\mathrm{F}} \cdot \mathrm{C}^{\mathrm{n}}
$$

where:

$\mathrm{S}=$ the amount of solute retained per unit weight of the adsorbent $(\mathrm{mmol} / \mathrm{kg})$

$\mathrm{C}=$ the equilibrium concentration of the solute remaining in the solution (mmol)

$\mathrm{K}_{\mathrm{L}}=$ constant related to the energy of adsorption $(\mathrm{L} / \mathrm{mmol})$

$\mathrm{S}_{\mathrm{m}}=$ the maximum adsorption capacity of the sample $(\mathrm{mmol} / \mathrm{g})$

$\mathrm{K}_{\mathrm{F}}$ and $\mathrm{n}=$ adjustable coefficients

The sorption with Freundlich equation extends infinitely as concentrations increase, which is not realistic since a limited number of sorption sites are expected. The sorption with the Langmuir equation shows that the sorbed concentration S increases linearly with solute concentration $\mathrm{C}$, if $\mathrm{C}<<\mathrm{K}_{\mathrm{L}}$. However, when the concentration is very high, $\mathrm{C}>>$ $\mathrm{K}_{\mathrm{L}}$, then the surface becomes saturated and $\mathrm{S}=\mathrm{S}_{\max }$, which indicates the limitation of the sorption site.

Cruz-Guzman et al. (2003) studied the sorption isotherm of $\mathrm{Hg}$ (II) on Ferrihydrite [Ferrih], Humic acid (HA) and Montmorillonite (SW). The mixtures (binary and ternary sorbents) between the sorbents were also performed to test their $\mathrm{Hg}(\mathrm{II})$ sorption capabilities. For the single model sorbent, the $\mathrm{Hg}(\mathrm{II})$ sorption capabilities are following the sequence of $\mathrm{HA}>\mathrm{Fe}(\mathrm{OH})_{3}>\mathrm{SW}$. The sorption isotherms of $\mathrm{Hg}(\mathrm{II})$ on all model sorbents (single, binary, and ternary sorbents) showed a strong Langmuir-character with $\mathrm{R}^{2}>0.98$ (Figures 3 and 4). The isotherms indicated a limited number of sorption sites exist and it became more difficult for the sorbing species to find a vacant site available when more sites in the sorbent were occupied. 


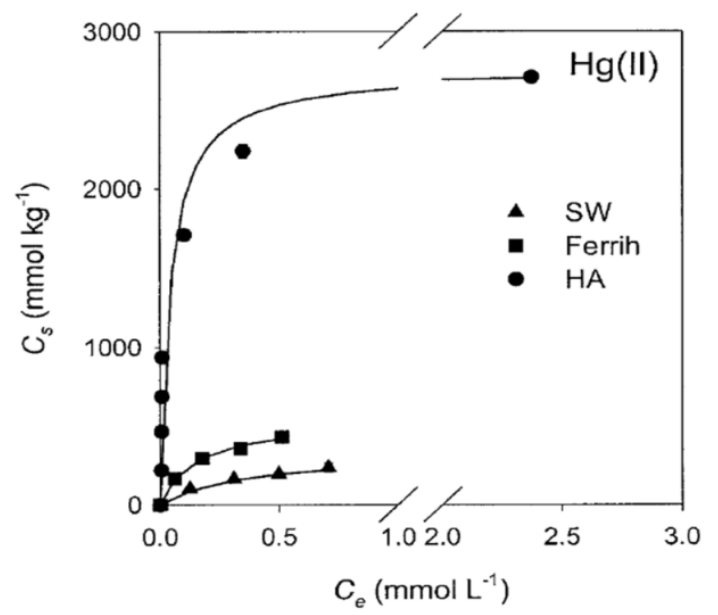

Figure $3 \mathrm{Hg}$ (II) sorption isotherm on single model sorbent (Cruz-Guzman et al., 2003)

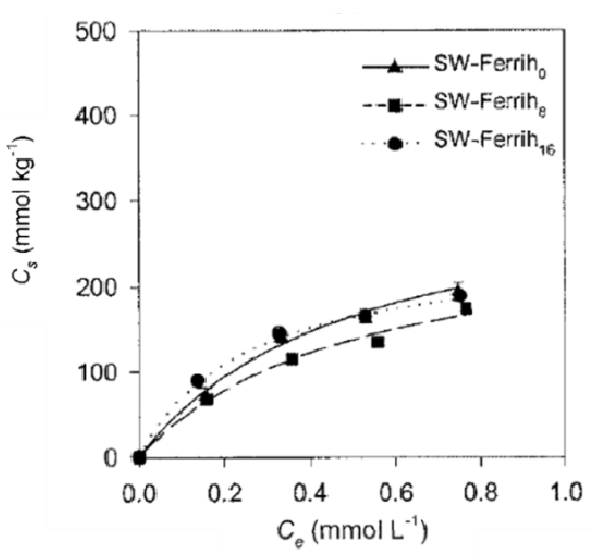

(a)

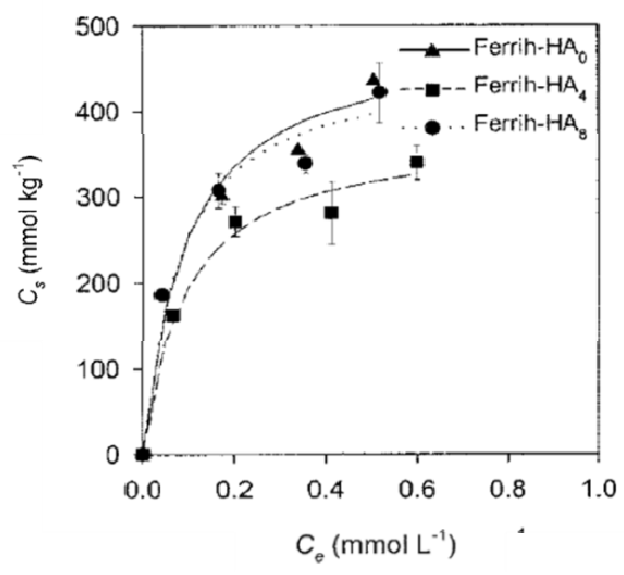

(c)

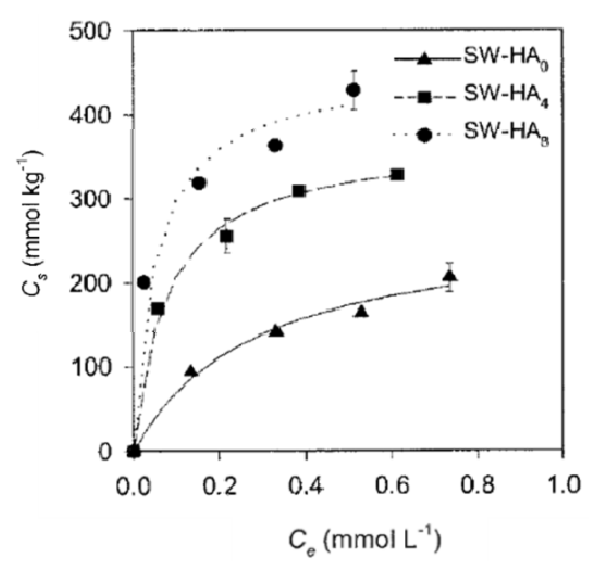

(b)

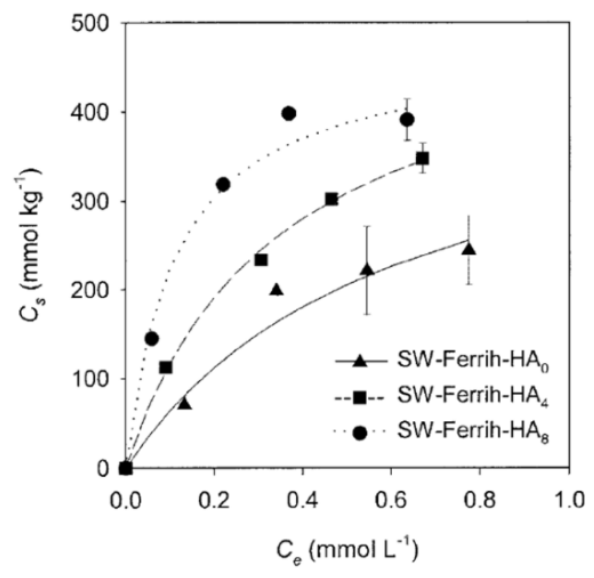

(d)

Figure $4 \mathrm{Hg}$ (II) sorption isotherms on binary (a), (b) and (c) and ternary (d) model sorbents (Cruz-Guzman et al., 2003) 
The characteristic of the sorbents used in Cruz-Guzman et al. (2003) study and the Langmuir isotherm results for $\mathrm{Hg}$ (II) sorption on all the model sorbents are shown in Table 16.

Table 16 The characteristic of the model sorbents and Langmuir Isotherm for $\mathrm{Hg}(\mathrm{II})$ sorptions Cruz-Guzman et al. (2003)

\begin{tabular}{|c|c|c|c|c|c|c|c|}
\hline \multirow{2}{*}{\multicolumn{2}{|c|}{ Model sorbents }} & \multicolumn{3}{|c|}{$\begin{array}{l}\text { Sorbent Composition } \\
\qquad(\%)\end{array}$} & \multicolumn{3}{|c|}{$\begin{array}{c}\text { Langmuir Parameters for } \\
\text { Hg(II) sorption }\end{array}$} \\
\hline & & SW & Ferrih & HA & $\begin{array}{c}\mathrm{S}_{\mathrm{m}} \\
\mathrm{mmol} / \mathrm{kg}\end{array}$ & $\begin{array}{c}\mathbf{K}_{\mathrm{L}} \\
\mathbf{L} / \mathbf{m m o l}\end{array}$ & $\mathbf{R}^{2}$ \\
\hline \multirow{3}{*}{$\begin{array}{l}\text { Single model } \\
\text { sorbents }\end{array}$} & SW & 100 & 0 & 0 & 319 & 4 & 0.99 \\
\hline & Ferrih & 0 & 100 & 0 & 536 & 7 & 0.99 \\
\hline & HA & 0 & 0 & 100 & 2750 & 23 & 0.99 \\
\hline \multirow{9}{*}{$\begin{array}{l}\text { Binary model } \\
\text { sorbents }\end{array}$} & SW-Ferrih 0 & 100 & 0 & 0 & 331 & 2 & 0.96 \\
\hline & SW-Ferrih $_{8}$ & 92.7 & 7.3 & 0 & 275 & 2 & 0.95 \\
\hline & SW-Ferrih 16 & 86.3 & 13.7 & 0 & 246 & 4 & 0.99 \\
\hline & SW-HA & 100 & 0 & 0 & 273 & 3 & 0.96 \\
\hline & $\mathrm{SW}-\mathrm{HA}_{4}$ & 95.7 & 0 & 4.3 & 369 & 13 & 0.99 \\
\hline & $\mathrm{SW}-\mathrm{HA}_{8}$ & 93.3 & 0 & 6.7 & 454 & 19 & 0.98 \\
\hline & Ferrih-HA & 0 & 100 & 0 & 490 & 11 & 0.97 \\
\hline & Ferrih-HA 4 & 0 & 96.4 & 3.7 & 376 & 11 & 0.98 \\
\hline & Ferrih-HA 8 & 0 & 93.1 & 6.9 & 459 & 13 & 0.97 \\
\hline \multirow{3}{*}{$\begin{array}{l}\text { Ternary model } \\
\text { sorbents }\end{array}$} & SW-Ferrih-HA ${ }_{0}$ & 85.2 & 14.8 & 0 & 462 & 2 & 0.82 \\
\hline & SW-Ferrih-HA 4 & 82.5 & 14.6 & 2.9 & 525 & 3 & 0.99 \\
\hline & SW-Ferrih-HA 8 & 81.0 & 13.5 & 5.5 & 474 & 9 & 0.98 \\
\hline
\end{tabular}


Liang et al. (2013) studied the sorption of $\mathrm{Hg}(\mathrm{II})$ on Goethite, Hydrous Manganese Oxides, and Birnessite in freshwater (salinity $=0 \%$ ) and marine water (salinity $=33 \%$ o). This was in order to study the effect of $\mathrm{Cl}^{-}$on the $\mathrm{Hg}(\mathrm{II})$ sorption isotherms. They found that the sorption isotherms can be well described by Langmuir isotherms as shown in Tables 17 (freshwater) and 18 (marine water).

Table 17 Langmuir parameters for $\mathrm{Hg}(\mathrm{II})$ sorption isotherm on Goethite, Hydrous Manganese Oxides, and Birnessite in freshwater (0\%o salinity, Liang et al., 2013)

\begin{tabular}{|l|ccc|}
\hline \multicolumn{1}{|c}{ Sorbents } & \multicolumn{3}{c|}{ Langmuir Parameters } \\
& $\begin{array}{c}\mathbf{S}_{\mathbf{m}} \\
\mathbf{m m o l} / \mathbf{m o l ~ F e ~ o r ~ M n ~}\end{array}$ & $\begin{array}{c}\mathbf{K}_{\mathbf{L}} \\
\mathbf{L m m o l}\end{array}$ & $\mathbf{R}^{2}$ \\
\hline Goethite & 1.4 & 0.36 & 0.92 \\
\hline Hydrous Manganese Oxides & 5.9 & 2.65 & 0.98 \\
\hline Birnessite & 0.4 & 9.46 & 0.97 \\
\hline
\end{tabular}

Table 18 Langmuir parameters for $\mathrm{Hg}(\mathrm{II})$ sorption isotherm on Goethite, Hydrous Manganese Oxides, and Birnessite in marine water (33\% salinity, Liang et al., 2013)

\begin{tabular}{|l|ccc|}
\hline \multicolumn{1}{|c}{ Sorbents } & \multicolumn{3}{c|}{ Langmuir Parameters } \\
& $\mathbf{S}_{\mathbf{m}}$ & $\mathbf{K}_{\mathbf{L}}$ & $\mathbf{R}^{2}$ \\
\hline Goethite & 0.013 & 0.047 & 0.99 \\
\hline Hydrous Manganese Oxides & 0.007 & 0.045 & 0.99 \\
\hline Birnessite & 0.006 & 0.071 & 0.99 \\
\hline
\end{tabular}

Liang et al. (2013) also found that the Langmuir isotherm parameters $\mathrm{S}_{\mathrm{m}}$ and $\mathrm{K}_{\mathrm{L}}$ were significantly higher in freshwater (Table 17) compared to marine water (Table 18). This indicated that the increase of salinity inhibited adsorption of $\mathrm{Hg}(\mathrm{II})$ on Goethite, Hydrous 
Manganese Oxides, and Birnessite. This is because the high reaction constant between $\mathrm{Hg}$ and $\mathrm{Cl}$ leads to high formation of a stable, non-sorbing aqueous $\mathrm{HgCl}_{2}$ complex in the solution, which limits the amount of free $\mathrm{Hg}(\mathrm{II})$ available to sorb.

\subsubsection{Hg(II) surface complexation kinetic}

Yin et al. (1997) studied the kinetics of $\mathrm{Hg}(\mathrm{II})$ adsorption on different soils which have different characteristic as shown in Table 19.

Table 19 Soil characteristics in Yin et al. (1997)

\begin{tabular}{|cccccccc|}
\hline soil no & soil name & \% sand & \% silt & \% clay & $\mathbf{p H}$ & $\begin{array}{c}\text { OC } \\
(\mathbf{g} / \mathbf{k g})\end{array}$ & $\begin{array}{c}\text { surface } \\
\mathbf{a r e a} \\
\left(\mathbf{m}^{2} / \mathbf{k g}\right)\end{array}$ \\
\hline 1 & $\begin{array}{c}\text { Freehold sandy } \\
\text { loam }\end{array}$ & 92 & 2 & 6 & 5.22 & 1.2 & 2040 \\
\hline 2 & $\begin{array}{c}\text { Sussafras sandy } \\
\text { loam }\end{array}$ & 45 & 37 & 18 & 5.78 & 3.5 & 5310 \\
\hline 3 & $\begin{array}{c}\text { Dunellen sandy } \\
\text { loam }\end{array}$ & 56 & 30 & 14 & 5.57 & 11 & 5210 \\
\hline 4 & $\begin{array}{c}\text { Rockaway stony } \\
\text { loam }\end{array}$ & 54 & 30 & 16 & 4.69 & 28 & 8620 \\
\hline
\end{tabular}

The kinetic sorption of $\mathrm{Hg}(\mathrm{II})$ on the soils can be described by the first order kinetic equation (equation 40)

$$
\frac{\mathrm{dC}}{\mathrm{dt}}=-\mathrm{k}_{\mathrm{m}}\left(\mathrm{C}_{\mathrm{t}}-\frac{\mathrm{S}_{\mathrm{t}}}{\mathrm{k}_{\mathrm{d}}}\right)
$$

where:

$$
\begin{aligned}
& \mathrm{dC} / \mathrm{dt} \text { is the reaction rate }(\mu \mathrm{g} / \mathrm{L} \min ) \text {, } \\
& \mathrm{k}_{\mathrm{m}} \text { is a mass transfer coefficient }\left(\mathrm{min}^{-1}\right) \text {, } \\
& \mathrm{C}_{\mathrm{t}} \text { is } \mathrm{Hg}(\mathrm{II}) \text { concentration }(\mu \mathrm{g} / \mathrm{L}) \text {, } \\
& \mathrm{S}_{\mathrm{t}} \text { is the sorbed concentration }(\mu \mathrm{g} / \mathrm{g} \text { soil }) \text {, and } \\
& \mathrm{k}_{\mathrm{d}} \text { is the distribution coefficient }(\mathrm{L} / \mathrm{g})
\end{aligned}
$$


The kinetic sorption parameters $\mathrm{k}_{\mathrm{d}}$ and $\mathrm{k}_{\mathrm{m}}$ for each soil obtained from the Yin et al. (1997) study are shown in Table 20.

Table 20 The kinetic sorption parameters of $\mathrm{Hg}(\mathrm{II})$ on different soils (Yin et al., 1997)

\begin{tabular}{|cccc|}
\hline soil no & soil name & $\mathbf{k}_{\mathbf{m}}\left(\mathbf{m i n}^{-1}\right)$ & $\mathbf{k}_{\mathbf{d}}(\mathbf{L} / \mathbf{g})$ \\
\hline 1 & Freehold sandy loam & $6.93 \mathrm{E}-05$ & 0.033 \\
\hline 2 & Sussafras sandy loam & $7.40 \mathrm{E}-05$ & 0.179 \\
\hline 3 & Dunellen sandy loam & $9.25 \mathrm{E}-05$ & 0.822 \\
\hline 4 & Rockaway stony loam & $1.07 \mathrm{E}-04$ & 2.100 \\
\hline
\end{tabular}

Krabbenhoft et al. (2007) conducted experiments on the $\mathrm{Hg}$ and $\mathrm{MeHg}$ kinetic adsorption on the Floridan aquifer bedrocks, for both aerobic and anaerobic conditions. The study aimed to investigate the possible changes to total $\mathrm{Hg}$ and $\mathrm{MeHg}$ concentrations in the Upper Floridan aquifer during operation of an ASR project. The kinetic experimental data for the first-order kinetic reaction (equation 41) was obtained. The kinetic parameters of $\mathrm{Hg}$ and $\mathrm{MeHg}$ sorption on Florida bedrock are shown in Table 21.

$$
\frac{d S}{d t}=k S_{t}
$$

where:

$\mathrm{S}_{\mathrm{t}}$ is sorption at time $\mathrm{t}$ (ng of $\mathrm{Hg} / \mathrm{kg}$ of bedrock),

$\mathrm{k}$ is the sorption rate constant $\left(\mathrm{day}^{-1}\right)$ 
Table 21 Sorption kinetic parameters for the $\mathrm{Hg}$ and $\mathrm{MeHg}$ on the Floridan aquifer bedrocks (Krabbenhoft et al., 2007)

\begin{tabular}{|ccc|} 
Condition & $\begin{array}{c}\mathbf{H g} \\
\mathbf{k}\left(\mathbf{d a y}^{-\mathbf{1}}\right)\end{array}$ & $\begin{array}{c}\mathbf{M e H g} \\
\mathbf{k}\left(\mathbf{d a y}^{-\mathbf{1}}\right)\end{array}$ \\
\hline Aerobic & 0.039 & 0.069 \\
\hline Anaerobic & 0.061 & 0.070 \\
\hline
\end{tabular}

\subsubsection{Hg(II) and Everglades peat complexation}

Drexel et al. (2002) studied the Hg(II) sorption of two Everglades peats collected at different locations in the Everglades: Water Conservation Area 2A (WCA2A) and Conservation Area 2B (WCA 2B). The Hg(II) sorption isotherms showed the competition for $\mathrm{Hg}(\mathrm{II})$ between peat and DOM released from peat. DOM and the Everglades peat consist of two sorption sites: a weak site and a strong site. The binding constants for weak and strong sites of both peat and DOM are shown in Table 22.

Table 22 Equilibrium binding constants (Drexel et al., 2002)

\section{Reactions}

WCA 2A

\section{WCA 2B}

Single site

$\begin{array}{lcc}\mathrm{K}_{\text {peat }} & 10^{12.0 \pm 0.1} & 10^{11.6 \pm 0.1} \\ \mathrm{~K}_{\text {dom }} & 10^{12.8 \pm 0.1} & 10^{9.0 \pm 2.6}\end{array}$

Double site

\begin{tabular}{lcc}
$\mathrm{K}_{\text {peat }, \mathrm{s}}$ & $10^{22.0 \pm 0.1}$ & $10^{21.8 \pm 0.1}$ \\
\hline $\mathrm{K}_{\text {peat }, \mathrm{w}}$ & $10^{11.8 \pm 0.1}$ & $10^{11.5 \pm 0.1}$ \\
\hline $\mathrm{K}_{\text {dom } \mathrm{s}}$ & $10^{23.2 \pm 0.1}$ & $10^{22.8 \pm 0.1}$ \\
\hline $\mathrm{K}_{\text {dom, } \mathrm{w}}$ & $10^{7.3 \pm 4.5}$ & $10^{8.7 \pm 3.0}$
\end{tabular}


The $\mathrm{K}_{\mathrm{d}}$ of $\mathrm{Hg}(\mathrm{II})$ in the Everglades peat reported by Drexel et al. (2002) are between $10^{4.1}$ to $10^{5.7} \mathrm{~L} / \mathrm{kg}$ depending on the $\mathrm{Hg}(\mathrm{II})$ concentration. These $\mathrm{K}_{\mathrm{d}}$ values are similar to the values that were reported by Hurley et al. (1998).

\subsection{Data and Site Study Selections}

\subsubsection{Data Selections}

The data used in this study were obtained from many sources including literature, technical reports of specific sites, and database websites (e.g., OREIS, DBHYDRO, SFWMD, etc.).

Data from selected research contributors were used to confirm the model estimation capability for $\mathrm{Hg}$. In order to confirm the model capability, the $\mathrm{Hg}$ experimental conditions obtained from the literature were set for the model. Then the model results were verified by the results from the literature. The model confirmation using the literature data was made for Hg-species, ion-exchange, and surface complexation processes.

Data from technical reports of the specific sites and related websites, including site geology, water quality data, flow characteristics, etc., were used for 2 purposes: 1) model confirmation 2) model application. The model confirmations are explained in sections 4.6 and 4.7. The model application for $\mathrm{Hg}$ geochemical and transport processes are documented in Chapter 6.

\subsubsection{Site Selections}

In this study, two test-beds, Oak Ridge Reservation (ORR) at Oak Ridge, TN, and South Florida Region, FL, were selected for the development and evaluation of $\mathrm{Hg}$ 
geochemical processes, and also for the application in fate and transport of the enhanced model.

ORR, Oak Ridge, TN consists of three large industrial production facilities constructed as part of the World War II-era Manhattan Project: the Oak Ridge National Laboratory (formerly known as the X-10 Site), K-25 Site, and the Y-12 National Security Complex or Y-12 Plant. The accidental spill and discharge of Hg to the surroundings of Y-12 plant was reported during the Y-12 operation time, 1950-1963 (Brooks and Southworth, 2011). Studies have also shown that $\mathrm{Hg}$ accumulated in the soil, rock, and groundwater of the site consequentially became sources of contamination to nearby rivers and creeks, such as the East Fork Poplar Creek (EFPC) located downstream from the Y12 plant (Figure 5). Many cleanups have been attempted for ORR sites. Y-12 is divided into the Bear Creek Valley Watershed and the Upper East Fork Poplar Creek (UEFPC) Watershed (Figure 5). Later on as part of this study, applications of the enhanced model of this research to understand the transport of $\mathrm{Hg}$ were made for Bear Creek Valley and EFPC within the Y-12 complex area. 


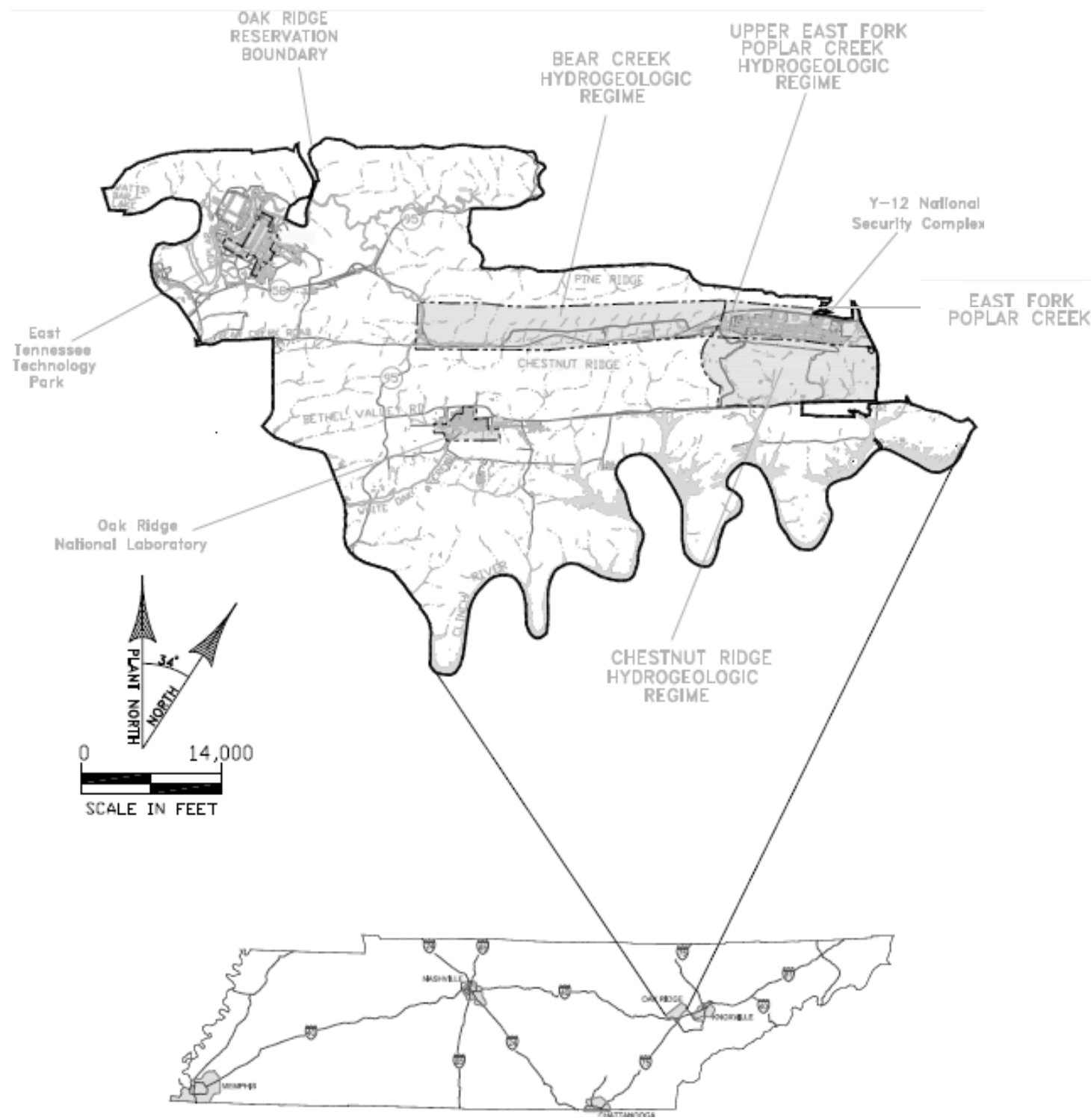

Figure 5 Oak Ridge Reservation Map (modified after www.esd.ornl.gov)

The South Florida region (Figure 6) includes the Florida aquifer and Everglades National Park (ENP). ENP is a unique wetland environment with a specific ecosystem and wildlife that has been reported to have contamination of $\mathrm{Hg}$. The high $\mathrm{Hg}$ levels are found in wildlife and especially in aquatic animals (e.g., fish, shell, etc.). Those findings have raised the concern of many researchers to investigate the $\mathrm{Hg}$ behavior in attempts to control the sources and implement cleanup. The unique water environment of ENP has 
water with high dissolved organic carbon (DOC) that also covers a wide range of salinity from oceanic to freshwater, which offers a special opportunity to study the Hg behavior under the effect of those main variables. The model was first tested for its capability to simulate major ions using data from the Florida aquifer. This test evaluated the model's ability to estimate typical ions, such as $\mathrm{Ca}, \mathrm{Mg}, \mathrm{Na}, \mathrm{K}$ and $\mathrm{SO}_{4}$, at different salinity levels (section 4.6) or ionic strengths. An encouraging confirmation would justify using the model to calculate the $\mathrm{Hg}$-species distribution of ENP water as a function of salinity. Second, the model with its enhanced thermodynamic database was used to investigate the fate and transport of $\mathrm{Hg}$ in ENP area as a function of DOC, peat and salinity.

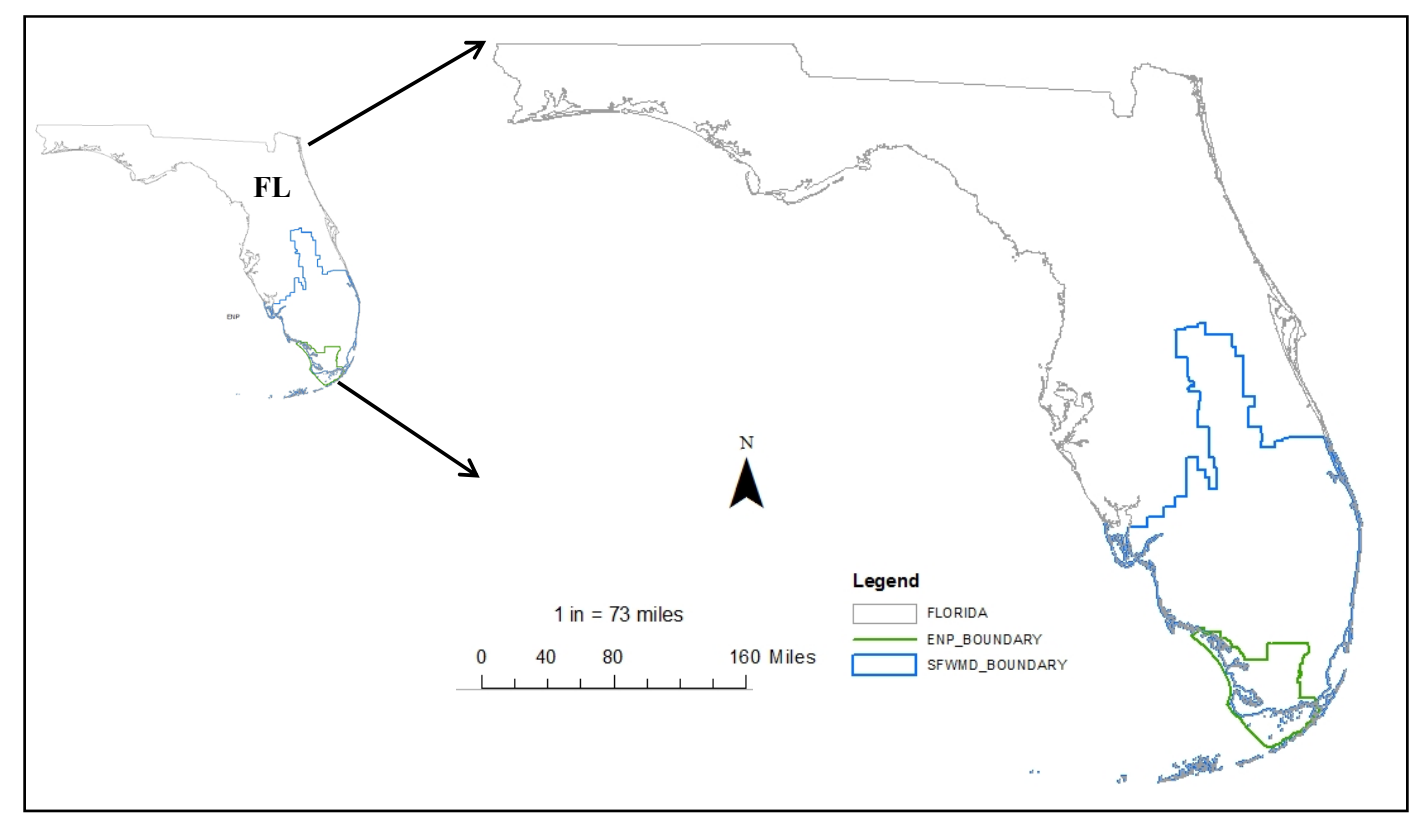

Figure 6 Everglades National Park (ENP)

The two test-beds were chosen because of the high concern of Hg contamination at the sites; another reason was that because of the difference in geology, water composition, and flow characteristics between these two sites, their evaluation would 
provide a better insight into the $\mathrm{Hg}$ behavior in a range of environmental condition. The major differences of the two sites are described below.

1. ENP surface water sediment is classified as the peat soil type, which consists up to 90\% of DOC. Drexel et al. (2002), Watanabe et al. (2012) and Evans et al. (2005) showed that peat releases vast amounts of DOC in the water column, resulting in high DOC concentration in ENP's surface water. DOC content in the peat sediment can retard the $\mathrm{Hg}$ from its transport while $\mathrm{DOC}$ in the water can form with $\mathrm{Hg}$ and move with the water. Thus, the DOC is one of the important factors that play an important role on fate and transport of $\mathrm{Hg}$ at this site. However, the studies (Hill et al., 2001; Depledge, M.H. 1999; Loar et al. 2011; Stewart et al., 2011) showed that the major sediment of ORR surface water, for example, sediment of EFPC, are sand, rock and gravel which consist of natural minerals, such as, $\mathrm{FeO}$ and $\mathrm{Fe}(\mathrm{OH})_{3}$. These minerals can complex with $\mathrm{Hg}$ and retard it from its transport. The typical EFPC surface water consists of various chemical compositions (e.g. $\mathrm{Ca}, \mathrm{Mg}, \mathrm{Zn}, \mathrm{Pb}$ ) however, the concentration of DOC is negligible (Loar et al. 2011; Southworth et al. 1995 and 1999) and was not considered for this site.

2. According to contaminant transport equation or Advection- ReactionDispersion (ARD) equation, $\frac{\partial C}{\partial t}=-v \frac{\partial C}{\partial x}+D_{L} \frac{\partial^{2} C}{\partial x^{2}}-\frac{\partial q}{\partial t}$, which the change of $\mathrm{Hg}$ concentration with time is a function of advection and dispersion transports and reactions. For these two selected sites, the physical parameters controlling the transport of $\mathrm{Hg}$ are significantly different. ENP surface water velocity $(\sim 777 \mathrm{~m} / \mathrm{d})$ and dispersion coefficient ( 4660 $\left.\mathrm{m}^{2} / \mathrm{d}\right)$ reported by Harvey et al.(2002 and 2005) and Leonard et al. (2006) are 
very low compared to those for EFPC surface water, velocity is $\sim 12,960 \mathrm{~m} / \mathrm{d}$ and dispersion coefficient is $\sim 77,000 \mathrm{~m}^{2} / \mathrm{d}$ (Vasquez, 2008; Loar et al., 2011). Thus, the evaluation of $\mathrm{Hg}$ transport of these two sites will help to better understand the $\mathrm{Hg}$ behavior and identify the physical parameters influenced its transport.

3. Groundwater settings and qualities of the both sites are different. Although, groundwater bedrock of the both sites mostly consist of limestone, however, the bedrock of ORR groundwater also consist of shale, kaolinite, gibbsite and $\mathrm{Fe}(\mathrm{OH})_{3}$. The last three minerals have abilities to complex with $\mathrm{Hg}$ resulting in retardation of $\mathrm{Hg}$ from its transport. The retardation of $\mathrm{Hg}$ by limestone is not studied in this dissertation. The analysis of ORR groundwater qualities showed significantly different from those for ENP. ORR groundwater qualities at different wells showed variation in $\mathrm{pH}$ value (Elvado Environmental LLC, 2009 and 2011), while ENP groundwater qualities showed variation in salinity (Blanco et al., 2013; Price et al., 2003; Walton 2007). Thus, the effects of $\mathrm{pH}$ and salinity on $\mathrm{Hg}$ transformation are investigated. This helps to understand the chemical processes influenced $\mathrm{Hg}$ fate and transport at different water conditions.

\subsection{Model Confirmation in Batch Mode - Lab Scale}

This section presents the tests of the model capability to simulate speciation, dissolution and precipitation, ion-exchange, surface complexation, and 1-D transport simulations. The model prediction was confirmed with both literature and field data for Hg and other species. The model capability tests were mostly done using data from the literature, for no field data is available for $\mathrm{Hg}$ fate as function of speciation, ion-exchange and surface complexation. However, field data were available to test the ability of the 
enhanced model to predict major ions such as $\mathrm{Ca}, \mathrm{Mg}, \mathrm{Na}, \mathrm{Cl}$, and $\mathrm{SO}_{4}$, which are usually present in aqueous environments.

\subsubsection{Testing Scenario 1: $\mathrm{Hg}-\mathrm{CH}_{3} \mathrm{COOH}$ (1 nmole: 0.33 mmole) \\ Complexation}

The Hg speciation prediction capability of PHREEQC with the enhanced database was satisfactorily compared with the experimental study of Gårdfeldt et al. (2003), which conducted experiments to define complexation of mercuric acetate at various $\mathrm{pH}$ values. Testing was done by simulating in PHREEQC the experimental conditions that Gårdfeldt et al. (2003) used in their study. The Gårdfeldt et al. (2003) study was conducted for 3 scenarios. The water conditions used in scenario 1 are shown in Table 23.

Table 23 Scenario 1 water condition in the Gårdfeldt et al. (2003) study used for model confirmation

\begin{tabular}{|ccc|}
\hline Parameter & Unit & Value \\
\hline $\mathrm{Hg}(\mathrm{II})$ & $\mathrm{nmol}$ & 1.0 \\
\hline Acetic acid $\left(\mathrm{CH}_{3} \mathrm{COOH}\right)$ & $\mathrm{mmol}$ & 0.33 \\
\hline $\mathrm{NaOH}$ & mole & (to adjust $\mathrm{pH})$ \\
\hline Temperature & ${ }^{\circ} \mathrm{C}$ & 20 \\
\hline
\end{tabular}

The comparison between the results from Gårdfeldt et al. (2003) and PHREEQC prediction using the enhanced database is shown in Figure 7. 


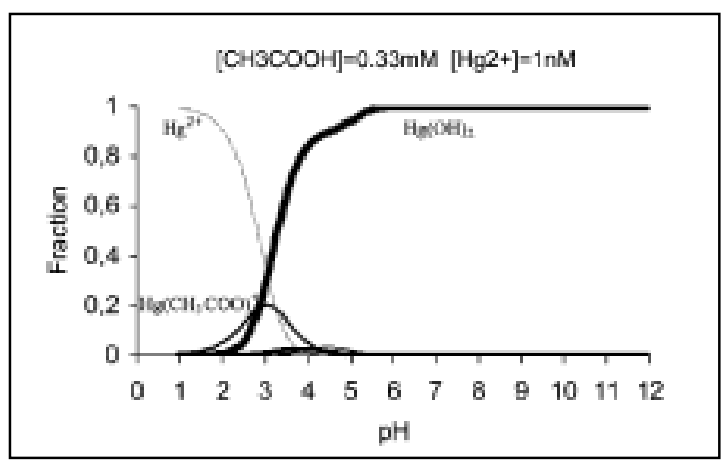

(a)

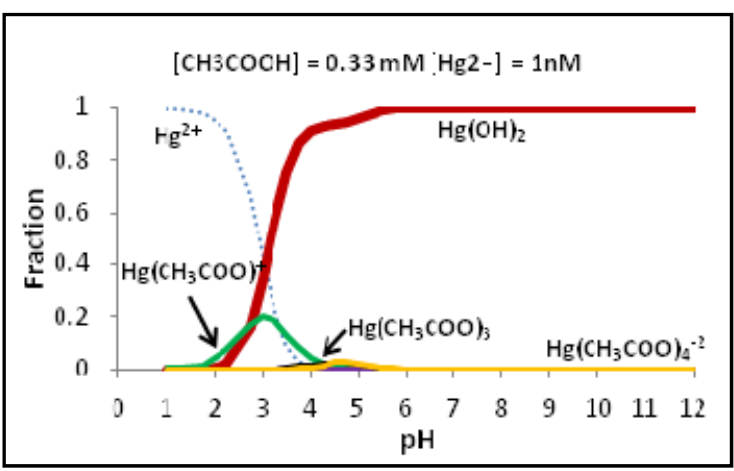

(b)

Figure 7 Model speciation prediction capability testing; scenario $1\left(\mathrm{Hg}: \mathrm{CH}_{3} \mathrm{COOH}=1\right.$ nmol : $0.33 \mathrm{mmol}$ ) result obtained from Gårdfeldt et al. (2003) (a) and enhanced PHREEQC model (b)

PHREEQC matches well the results of Gårdfeldt et al. (2003); the prediction showed $\mathrm{Hg}^{2+}$ to be dominant at $\mathrm{pH}=1$ before a sharp decrease between $\mathrm{pH} 1-4 \cdot \mathrm{Hg}(\mathrm{OH})_{2}$ increased sharply between $\mathrm{pH}$ 2-5 and reached its maximum, being dominant at $\mathrm{pH}$ 6-12, while $\mathrm{Hg}\left(\mathrm{CH}_{3} \mathrm{COO}\right)^{-}$peaks at $\mathrm{pH} 3$.

\subsubsection{Testing Scenario 2: $\mathrm{Hg}-\mathrm{CH}_{3} \mathrm{COOH}$ (1 nmole: 3.3 mmole) \\ Complexation}

The water conditions used for the scenario 2 in the Gårdfeldt et al. (2003) study are shown in Table 24.

Table 24 Scenario 2: water condition in the Gårdfeldt et al. (2003) study used for model confirmation

\begin{tabular}{|ccc|}
\hline Parameter & Unit & Value \\
\hline $\mathrm{Hg}(\mathrm{II})$ & $\mathrm{nmol}$ & 1.0 \\
\hline $\begin{array}{c}\text { Acetic acid } \\
\left(\mathrm{CH}_{3} \mathrm{COOH}\right)\end{array}$ & $\mathrm{mmol}$ & 3.3 \\
\hline $\mathrm{NaOH}$ & mole & (to adjust $\mathrm{pH})$ \\
\hline Temperature & ${ }^{\circ} \mathrm{C}$ & 20 \\
\hline
\end{tabular}


The comparison between the results of the $\mathrm{Hg}-\mathrm{CH}_{3} \mathrm{COOH}$ complexation, that is scenario 2 of the Gårdfeldt et al. (2003) experiments and the enhanced PHREEQC prediction results is shown in Figure 8.

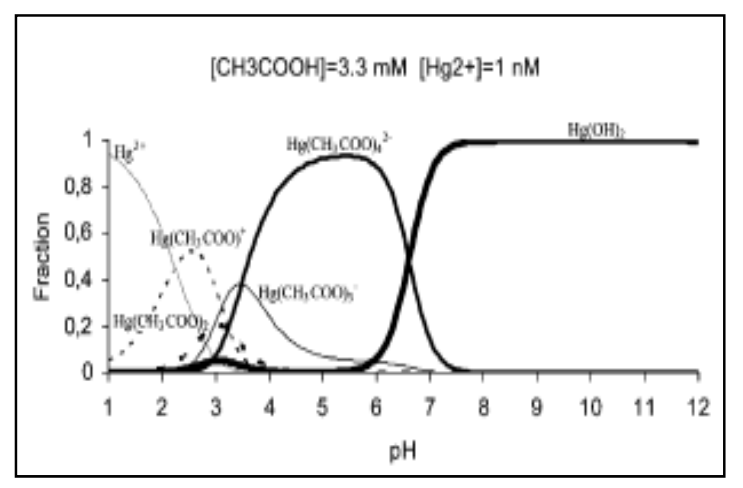

(a)

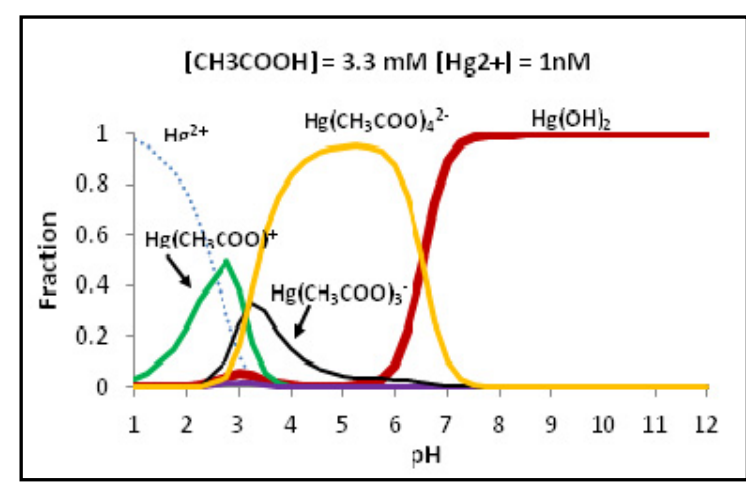

(b)

Figure 8 Model speciation prediction capability testing; the scenario $2\left(\mathrm{Hg}: \mathrm{CH}_{3} \mathrm{COOH}=\right.$ $1 \mathrm{nmol}: 3.3 \mathrm{mmol}$ ) result obtained from Gårdfeldt et al. (2003) (a) and enhanced PHREEQC model (b).

PHREEQC predictions trace well Gårdfeldt et al. (2003) experimental results of the Hg$\mathrm{CH}_{3} \mathrm{COOH}$ species distribution for all $\mathrm{pH}$ values. A decrease in $\mathrm{Hg}^{2+}$ is predicted between $\mathrm{pH}$ 1-3, while $\mathrm{Hg}\left(\mathrm{CH}_{3} \mathrm{COO}\right)^{+}$and $\mathrm{Hg}\left(\mathrm{CH}_{3} \mathrm{COO}\right)_{3}^{-}$showed their peak concentrations at $\mathrm{pH} 2.8$ and 3.2 , respectively. $\mathrm{Hg}\left(\mathrm{CH}_{3} \mathrm{COO}\right)_{4}{ }^{2-}$ was the dominant species between $\mathrm{pH}$ 4-6 with a sharp decrease at higher $\mathrm{pH}$ values. An increase in the concentration of $\mathrm{Hg}(\mathrm{OH})_{2}$ species occurred between $\mathrm{pH}$ 6-7, which then peaked at $\mathrm{pH} 8$, being the only the dominant species between $\mathrm{pH}$ 8-12. 


\subsubsection{Testing Scenario 3: $\mathrm{Hg}-\mathrm{CH}_{3} \mathrm{COOH}$ (1 nmole: 33 mmole) \\ Complexation}

The water conditions used for scenario 3 are shown in Table 25.

Table 25 Scenario 3: water condition in the Gårdfeldt et al. (2003) study used for model confirmation

\begin{tabular}{|ccc|}
\hline Parameter & Unit & Value \\
\hline $\mathrm{Hg}(\mathrm{II})$ & $\mathrm{nmol}$ & 1.0 \\
\hline $\begin{array}{c}\text { Acetic acid } \\
\left(\mathrm{CH}_{3} \mathrm{COOH}\right)\end{array}$ & mmol & 33 \\
\hline $\mathrm{NaOH}$ & mole & (to adjust $\mathrm{pH})$ \\
\hline Temperature & ${ }^{\circ} \mathrm{C}$ & 20 \\
\hline
\end{tabular}

The comparison between PHREEQC predictions of $\mathrm{Hg}-\mathrm{CH}_{3} \mathrm{COOH}$ complexation, that is scenario 3 in the Gårdfeldt et al. (2003) study is shown in Figure 9.

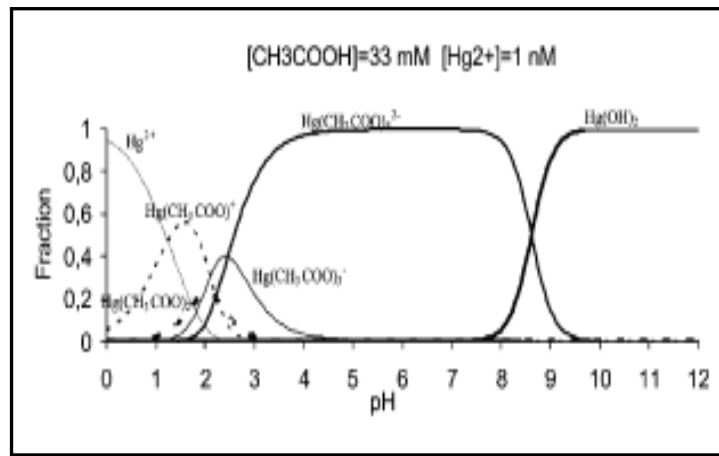

(a)

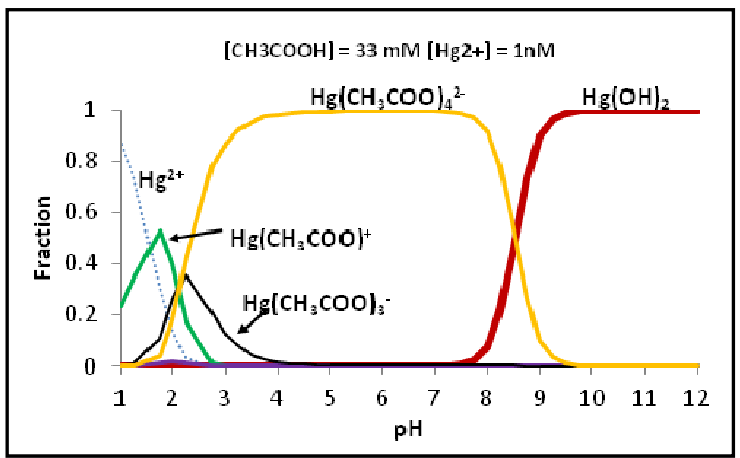

(b)

Figure 9 Model speciation prediction capability testing; the scenario $2\left(\mathrm{Hg}: \mathrm{CH}_{3} \mathrm{COOH}=\right.$ $1 \mathrm{nmol}: 33 \mathrm{mmol}$ ) result obtained from Gårdfeldt et al. (2003) (a) and enhanced PHREEQC model (b)

Figures 9 (a) and (b) respectively depict the results of Gårdfeldt et al., 2003 (a) and the prediction with the enhanced PHREEQC model (b); the predictions are quite comparable. $\mathrm{Hg}^{2+}$ was estimated to be dominant at $\mathrm{pH} 1$ before a sharp decrease in concentration at 
pH 2. The $\mathrm{Hg}\left(\mathrm{CH}_{3} \mathrm{COO}\right)^{+}$and $\mathrm{Hg}\left(\mathrm{CH}_{3} \mathrm{COO}\right)_{3}{ }^{-}$peak concentrations shifted to lower $\mathrm{pH}$ values compared to the previous scenarios. Increase in $\mathrm{CH}_{3} \mathrm{COOH}$ in the solution promoted the complexation of $\mathrm{Hg}\left(\mathrm{CH}_{3} \mathrm{COO}\right)_{4}{ }^{2-}$, as dominant in concentration between pH 3-8, replacing $\mathrm{Hg}(\mathrm{OH})_{2}$ as the dominant species in comparison to previous scenarios. The $\mathrm{Hg}(\mathrm{OH})_{2}$ species dominated between $\mathrm{pH}$ 9-12.

\subsubsection{Testing Scenario 4: MeHg complexation}

The testing of PHREEQC for its capability to calculate the complexation of MeHg at various $\mathrm{pH}$ values was conducted with the enhanced PHREEQC model by comparing it to Gårdfeldt et al. (2001) experimental conditions as shown in Table 26.

Table 26 Scenario 4: water condition in Gårdfeldt et al. (2001) study used for model validation for $\mathrm{MeHg}$ complexation

\begin{tabular}{|ccc|}
\hline Parameter & Unit & Value \\
\hline DI Water & $\mathrm{L}$ & 1.0 \\
\hline $\mathrm{CH}_{3} \mathrm{HgCl}$ & $\mathrm{ppb}$ & 25 \\
\hline $\mathrm{PO}_{4}{ }^{3-}$ & mole & (to adjust $\mathrm{pH}$ ) \\
\hline Temperature & ${ }^{\circ} \mathrm{C}$ & 20 \\
\hline
\end{tabular}

The results obtained from both the Gårdfeldt et al. (2001) experiments study and the enhanced PHREEQC model are shown in Figure 10 side by side. 


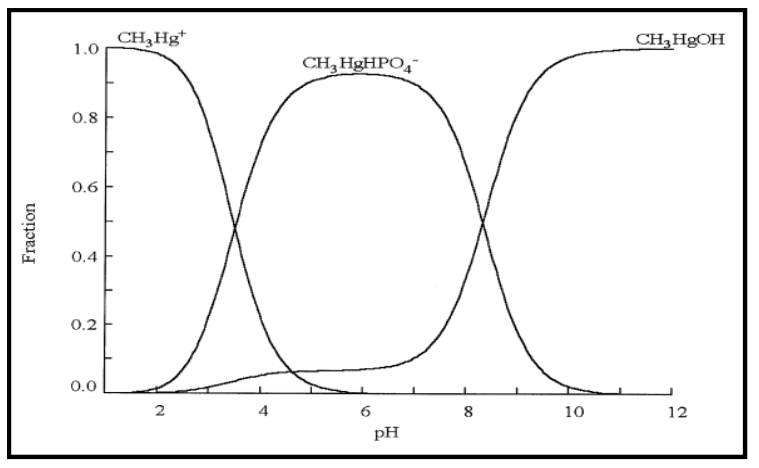

(a)

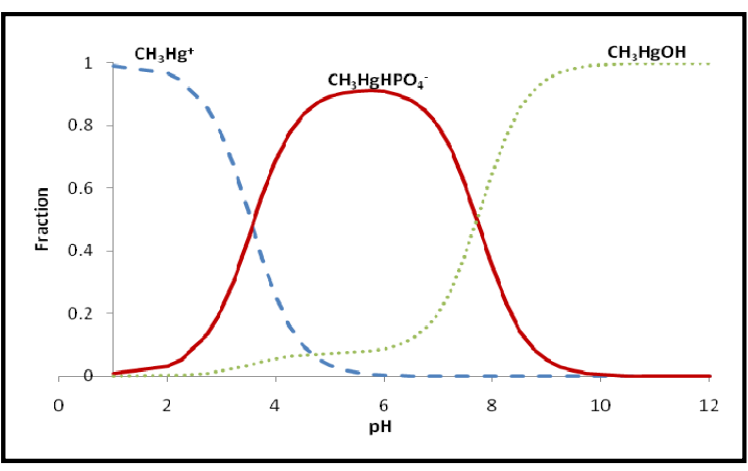

(b)

Figure 10 Model speciation prediction capability testing; the scenario $4 \mathrm{MeHg}$ complexation result obtained from Gårdfeldt et al. (2001) (a) and enhanced PHREEQC model (b)

Figure 10 shows that the enhanced PHREEQC model reproduces well the $\mathrm{MeHg}$ complexation and its speciation distribution for all $\mathrm{pH}$ values at the experimental

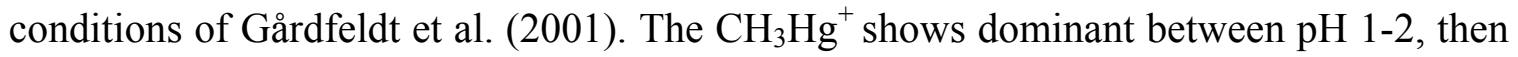
has a sharp decrease in its concentration between $\mathrm{pH} 2-5$ and goes to very low concentrations beyond $\mathrm{pH}$ 6. The dominated species at $\mathrm{pH}$ 4-8 was $\mathrm{CH}_{3} \mathrm{HgHPO}_{4}{ }^{-}$, while $\mathrm{CH}_{3} \mathrm{HgOH}$ dominates within $\mathrm{pH}$ 8-12.

\subsection{Process Confirmation in Batch Mode - Lab Scale}

\subsubsection{Testing Scenario 1: $\mathrm{Hg}(\mathrm{II})$ Surface Complexation on $\mathrm{Fe}(\mathrm{OH})_{3}$}

The enhanced PHREEQC model surface complexation calculation capability for the $\mathrm{Hg}(\mathrm{II})$ surface complexation on $\mathrm{Fe}(\mathrm{OH})_{3}$ was tested in reference to the experiments by Cruz-Guzman et al. (2003) study (Table 27). 
Table 27 Scenario 1: sorption experimental condition in the Cruz-Guzman et al. (2003) study used for model confirmation for $\mathrm{Hg}(\mathrm{II})$ surface complexation on $\mathrm{Fe}(\mathrm{OH})_{3}$

\begin{tabular}{|ccc|}
\hline Parameter & Unit & Value \\
\hline $\mathrm{Fe}(\mathrm{OH})_{3}$ Sorbent & $\mathrm{mg}$ & 10 \\
\hline $\mathrm{Hg}\left(\mathrm{NO}_{3}\right)_{2}$ & $\mathrm{mmol} / \mathrm{L}$ & $0.25-1$ \\
\hline Temperature & ${ }^{\circ} \mathrm{C}$ & 20 \\
\hline $\mathrm{pH}$ & - & $3.0 \pm 0.3$ \\
\hline
\end{tabular}

The PHREEQC model was used to calculate the $\mathrm{Hg}(\mathrm{II})$ sorption by surface complexation with $\mathrm{Fe}(\mathrm{OH})_{3}$ using the specific surface area characteristics of $\mathrm{Fe}(\mathrm{OH})_{3}$ and the thermodynamic data added to the model. The model result was then compared with the experimental sorption data obtained by Cruz-Guzman et al. (2003) (Figure 11).

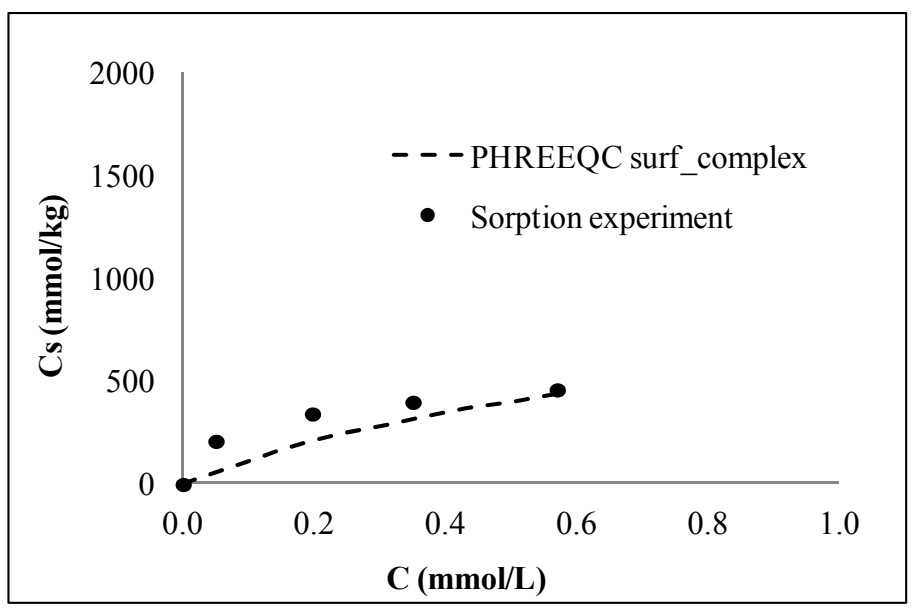

Figure 11 The model surface complexation prediction capability testing for scenario 1: $\mathrm{Hg}(\mathrm{II})$ surface complexation on $\mathrm{Fe}(\mathrm{OH})_{3}$, sorption experimental result Cruz-Guzman et al. (2003) (dot); the enhanced PHREEQC model (dashed line) 
Figure 11 shows the plot between the concentration of $\mathrm{Hg}$ in $\mathrm{Fe}(\mathrm{OH})_{3}\left(\mathrm{C}_{\mathrm{s}}\right)$ and in water (C) as estimated by the model and the experimental data Cruz-Guzman et al. (2003); the values are within the same range and trend comparably. The comparison indicates that the concept, mathematics of surface complexation and the needed thermodynamic data added into PHREEQC are quite appropriate to represent the sorption of $\mathrm{Hg}$ (II) on $\mathrm{Fe}(\mathrm{OH})_{3}$ surface.

\subsubsection{Testing Scenario 2: Hg(II) Sorption on Humic Acid}

In this scenario, the enhanced PHREEQC model was used to test its capability to predict the sorption of $\mathrm{Hg}(\mathrm{II})$ on Humic Acid (HA), using the added thermodynamic database obtained from Yin et al. (1997). The sorption experimental conditions obtained in the Cruz-Guzman et al. (2003) study (Table 28) were used to assess the model predictive performance.

The same experimental condition in Table 28 was used to compare PHREEQC simulation of sorption with the Cruz-Guzman et al. (2003) sorption experimental result (Figure 12).

Table 28 Scenario 2: sorption experimental condition in the Cruz-Guzman et al. (2003) study used for model confirmation for $\mathrm{Hg}$ (II) sorption of Humic Acid

\begin{tabular}{|ccc|}
\hline Parameter & Unit & Value \\
\hline $\mathrm{HA}$ Sorbent & $\mathrm{mg}$ & 10 \\
\hline $\mathrm{Hg}\left(\mathrm{NO}_{3}\right)_{2}$ & $\mathrm{mmol} / \mathrm{L}$ & $0.25-5$ \\
\hline Temperature & ${ }^{\circ} \mathrm{C}$ & 20 \\
\hline $\mathrm{pH}$ & - & $3.0 \pm 0.3$ \\
\hline
\end{tabular}




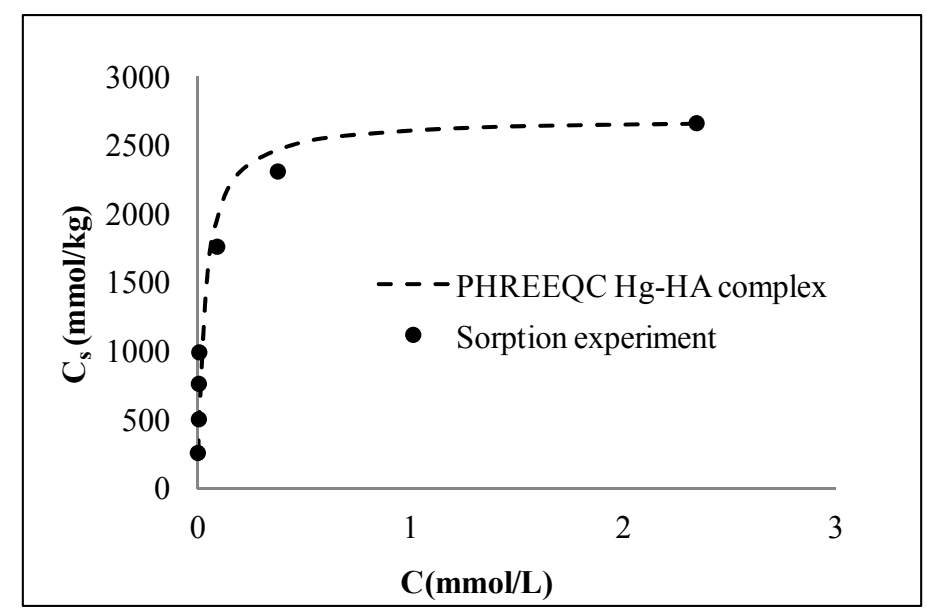

Figure 12 The model Hg-HA complexation prediction capability testing for scenario 2: sorption experimental result Cruz-Guzman et al. (2003) (dot); enhanced PHREEQC model (dashed line)

The results of Hg-HA sorption isotherm obtained from both the enhanced PHREEQC model and the experimental study were quite comparable. The comparison of both results in Figure 12 confirmed that the concept, mathematics and thermodynamic database of Hg-HA surface complexation that was added to enhance the PHREEQC model reproduces well the from experimental results of the reference, adding confidence to the use of the enhanced PHREEQC model for the prediction of $\mathrm{Hg}(\mathrm{II})$ sorption on the HA.

\subsubsection{Testing Scenario 3: Hg and MeHg Sorption Kinetic on Floridan Aquifer Bedrocks}

The model was tested for its capability to calculate the kinetic sorption of $\mathrm{Hg}$ and $\mathrm{MeHg}$ on the Florida aquifer bedrocks at both aerobic and anaerobic conditions using the first-order kinetic rate equation, $\frac{d S}{d t}=k S_{t}$, and rate parameters shown earlier in Table 21. The sorption experimental conditions in the Krabbenhoft et al. (2007) study were used for the model simulations (Table 29). 
Table 29 Scenario 3: water condition used to test the model capability for $\mathrm{Hg}$ and $\mathrm{MeHg}$ kinetic sorption on Floridan aquifer bedrock (Krabbenhoft et al., 2007)

\begin{tabular}{|ccl|}
\hline Parameters & Unit & Value \\
\hline Aquifer bedrock Sorbent & $\mathrm{kg}$ & 1 \\
\hline Water solution & $\mathrm{mmol} / \mathrm{L}$ & $0.2-5.0$ \\
\hline $\mathrm{pH}$ & - & 7.4 \\
\hline Temp & ${ }^{\circ} \mathrm{C}$ & 23 \\
\hline Alkalinity & $\mathrm{mg} / \mathrm{L}$ & 150 \\
\hline Calcium & $\mathrm{mg} / \mathrm{L}$ & 12.1 \\
\hline Magnesium & $\mathrm{mg} / \mathrm{L}$ & 6.8 \\
\hline Potassium & $\mathrm{mg} / \mathrm{L}$ & 45.3 \\
\hline Sodium & $\mathrm{mg} / \mathrm{L}$ & 87 \\
\hline Chloride & $\mathrm{mg} / \mathrm{L}$ & 28.7 \\
\hline Sulfate & $\mathrm{mg} / \mathrm{L}$ & 0.09 \\
\hline Hg & $\mathrm{ng} / \mathrm{L}$ & \\
\hline MeHg & & 2.1 \\
\hline
\end{tabular}

The kinetic sorption results calculated by the model were then compared with the experimental results of Krabbenhoft et al. (2007). The comparison is shown in Tables 30 and 31 for $\mathrm{Hg}(\mathrm{II})$ and $\mathrm{MeHg}$, respectively. 
Table 30 Scenario 3: Comparison results of $\mathrm{Hg}$ kinetic sorption on Floridan aquifer bedrock between Krabbenhoft et al. (2007) study and kinetic model calculation

\begin{tabular}{|c|c|c|c|c|}
\hline Condition & Time & $\begin{array}{c}\text { Experiment } \\
\text { Dissolved Hg, } \\
\text { ng/L }\end{array}$ & $\begin{array}{c}\text { Experiment } \\
\text { Sorbed Hg, ng/kg }\end{array}$ & $\begin{array}{c}\text { Model } \\
\text { Sorbed Hg, } \\
\text { ng/kg }\end{array}$ \\
\hline Initial & $2 / 4 / 2004$ & 2.14 & 0 & 0 \\
\hline \multirow{5}{*}{$\begin{array}{l}\text { Aerobic } \\
\text { Condition }\end{array}$} & $2 / 4 / 2004$ & 2.14 & 0 & 0 \\
\hline & $2 / 18 / 2004$ & 1.74 & 0.39 & 0.21 \\
\hline & $3 / 17 / 2004$ & 0.67 & 1.47 & 1.40 \\
\hline & $4 / 15 / 2004$ & 0.33 & 1.81 & 1.79 \\
\hline & $5 / 13 / 2004$ & 0.16 & 1.97 & 1.98 \\
\hline \multirow{5}{*}{$\begin{array}{l}\text { Anaerobic } \\
\text { Condition }\end{array}$} & $2 / 4 / 2004$ & 1.45 & 0.68 & 0.71 \\
\hline & $2 / 18 / 2004$ & 0.75 & 1.39 & 1.12 \\
\hline & $3 / 17 / 2004$ & 0.55 & 1.58 & 1.65 \\
\hline & $4 / 15 / 2004$ & 0.24 & 1.89 & 2.00 \\
\hline & $5 / 13 / 2004$ & 0.13 & 2.01 & 2.20 \\
\hline
\end{tabular}


Table 31Scenario 3: Comparison results of MeHg kinetic sorption on Floridan aquifer bedrock between Krabbenhoft et al. (2007) study and kinetic model calculation

\begin{tabular}{|c|c|c|c|c|}
\hline Condition & Time & $\begin{array}{l}\text { Experiment } \\
\text { Dissolved } \\
\mathrm{MeHg}, \mathrm{ng} / \mathrm{L}\end{array}$ & $\begin{array}{c}\text { Experiment } \\
\text { Sorbed MeHg, } \\
\text { ng/kg }\end{array}$ & $\begin{array}{c}\text { Model } \\
\text { Sorbed MeHg, } \\
\text { ng/kg }\end{array}$ \\
\hline Initial & 2/4/2004 & 0.090 & 0.0 & 0.0 \\
\hline \multirow{5}{*}{$\begin{array}{l}\text { Aerobic } \\
\text { Condition }\end{array}$} & 2/4/2004 & 0.085 & 0.005 & 0.005 \\
\hline & $2 / 18 / 2004$ & 0.024 & 0.066 & 0.064 \\
\hline & $3 / 17 / 2004$ & 0.009 & 0.081 & 0.094 \\
\hline & $4 / 15 / 2004$ & 0.005 & 0.085 & 0.102 \\
\hline & $5 / 13 / 2004$ & 0.006 & 0.084 & 0.102 \\
\hline \multirow{5}{*}{$\begin{array}{l}\text { Anaerobic } \\
\text { Condition }\end{array}$} & $2 / 4 / 2004$ & 0.090 & 0.0 & 0.0 \\
\hline & $2 / 18 / 2004$ & 0.028 & 0.062 & 0.061 \\
\hline & $3 / 17 / 2004$ & 0.023 & 0.067 & 0.076 \\
\hline & $4 / 15 / 2004$ & 0.014 & 0.076 & 0.079 \\
\hline & $5 / 13 / 2004$ & 0.015 & 0.075 & 0.079 \\
\hline
\end{tabular}

The kinetic sorption results calculated from the model and plotted against the experimental results are shown in Figure 13. 

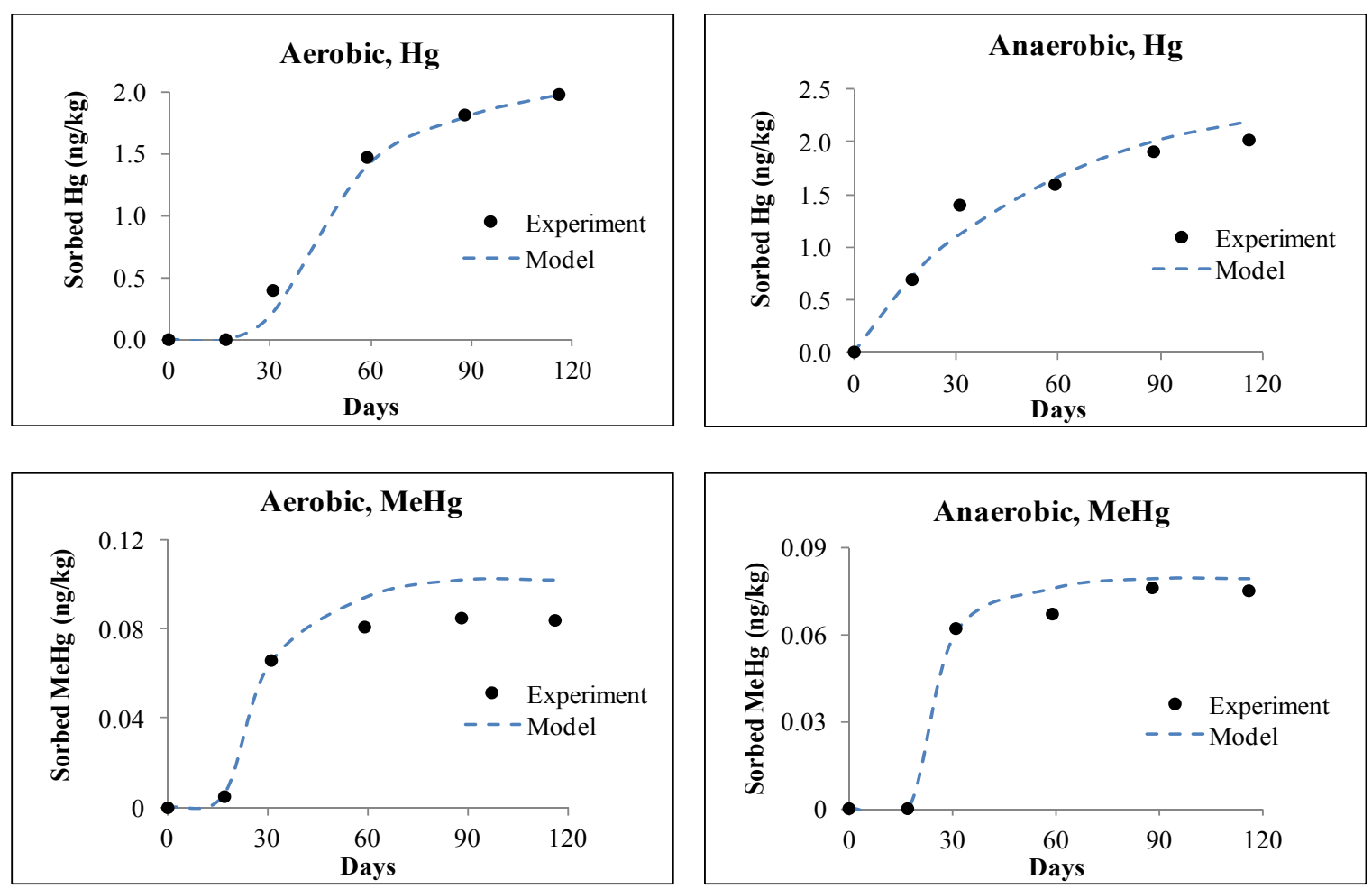

Figure 13 The model kinetic sorption prediction capability testing for scenario $3: \mathrm{Hg}$ and $\mathrm{MeHg}$ kinetic sorption on Floridan aquifer bedrock experimental result Krabbenhoft et al. (2007) (dot); enhanced PHREEQC model (dashed line).

Tables 30 and 31 and Figure 13 show that the model provided similar sorption kinetic trends to those of the experimental results for both $\mathrm{Hg}$ and $\mathrm{MeHg}$. This reaffirms that the model is capable of calculating the kinetic sorption for $\mathrm{Hg}$ and $\mathrm{MeHg}$ in the Florida aquifer bedrock. 


\subsection{Mathematical Model Confirmation in Batch Mode - Field Scale}

\subsubsection{Testing Scenario 1: Model Prediction Capability for Major Ions at Wide Range of Ionic Strength (Increase in Salinity)}

In this section, the model was tested for its capability to predict the change in dissolution and precipitation of major ions (i.e., $\mathrm{Ca}^{2+}, \mathrm{Mg}^{2+}, \mathrm{K}^{+}, \mathrm{Na}^{+}, \mathrm{Cl}^{-}$and $\mathrm{SO}_{4}{ }^{2-}$ ), which are the main constituents in the groundwater of the Floridan aquifer, with the effect of salinity caused by the intrusion of seawater (Price et al., 2003). This testing will also help to confirm that the model can be used for a wide range of ionic strengths of water ( $I$ is less than 0.02 for freshwater, and $\sim 0.7$ for seawater). In order to test the model prediction capability, a series of model simulations, mixing saline with freshwater, were carried out within assumptions. Then the comparison between model results and water quality data obtained from over 30 monitoring wells in the central to south Florida regions were made. The average freshwater and seawater water quality data, during the years 2005-2006, obtained from the DBHYDRO database website were used for the model testing. The freshwater monitoring well locations are shown in Table 32.

Table 32 The location of the selected freshwater water quality monitoring stations (DBHYDRO)

\begin{tabular}{|ccccc|}
\hline Parameter & S332BES & S332CWD & S332CWS & S332DES \\
\hline S332BES & 253254.185 & 803343.98 & Miami-Dade & East Coast Buffer \\
\hline S332CWD & 253053.735 & 803429.21 & Miami-Dade & Everglades National Park \\
\hline S332CWS & 252809.954 & 803427.64 & Miami-Dade & Everglades National Park \\
\hline S332CWS & 252809.954 & 803427.64 & Miami-Dade & Everglades National Park \\
\hline S332DES & 252717.076 & 803421.91 & Miami-Dade & East Coast Buffer \\
\hline
\end{tabular}


The average freshwater and seawater water quality data for the major ions, including $\mathrm{Ca}, \mathrm{K}, \mathrm{Na}, \mathrm{Mg}, \mathrm{Fe}, \mathrm{DO}, \mathrm{Cl}, \mathrm{SO}_{4}$, and Alkalinity, are shown in Tables 33 and 34 , respectively.

Table 33 Freshwater water quality used for the fresh-seawater mixing model, unit in $\mathrm{mg} / \mathrm{L}$ for major ion and ${ }^{\circ} \mathrm{C}$ for temperature (DBHYDRO)

\begin{tabular}{|ccccccc|}
\hline Parameter & S332BES & S332CWD & S332DWS & S332DES & S332CWS & Average \\
\hline $\mathrm{pH}$ & $7.0-7.6$ & $6.8-7.2$ & $6.9-7.4$ & $6.7-7.3$ & $6.8-7.3$ & 7.15 \\
\hline $\mathrm{Temp}$ & $23.0-28.8$ & $25.9-23.3$ & $22.8-30.1$ & $25.1-26.9$ & $23.1-29.4$ & 25.78 \\
\hline $\mathrm{Alkalinity}$ & $205-224$ & $202-221$ & $194-226$ & $198-220$ & $203-221$ & 209.39 \\
\hline $\mathrm{Ca}$ & $66.2-77.0$ & $71.2-77.2$ & $66.1-74.9$ & $74.3-77.6$ & $66.7-76.1$ & 73.1 \\
\hline $\mathrm{K}$ & $2.8-7.0$ & $1.8-2.7$ & $1.5-2.8$ & $2.1-2.9$ & $1.5-2.8$ & 2.47 \\
\hline $\mathrm{Na}$ & $32.2-45.5$ & $29.7-37.0$ & $19.7-34.2$ & $22.0-30.7$ & $27.0-40.5$ & 31.39 \\
\hline $\mathrm{Mg}$ & $8.2-10.1$ & $6.1-7.4$ & $5.0-8.3$ & $5.1-5.7$ & $5.5-8.3$ & 6.95 \\
\hline $\mathrm{Fe}$ & $0.24-0.30$ & $0.18-0.45$ & $0.22-0.33$ & $0.55-0.84$ & $0.22-0.45$ & 0.39 \\
\hline $\mathrm{DO}$ & $0.12-0.19$ & $0.09-0.14$ & $0.06-0.18$ & $0.06-0.35$ & $0.08-0.35$ & 0.13 \\
\hline $\mathrm{Cl}$ & $49.5-68.1$ & $43.8-58.2$ & $29.8-53.2$ & $40.7-47.3$ & $40.2-61.7$ & 47.53 \\
\hline & $0.7-5.8$ & $0.3-1.7$ & $0.5-3.7$ & $0.1-0.4$ & $0.1-2.7$ & 1.12 \\
\hline
\end{tabular}


Table 34 Seawater water quality used for the fresh-seawater mixing model (DBHYDRO)

\begin{tabular}{|ccc|}
\hline Parameter & Unit & Value \\
\hline $\mathrm{pH}$ & - & 8.2 \\
\hline $\mathrm{pe}$ & - & 8.4 \\
\hline density & $\mathrm{mg} / \mathrm{L}$ & 1.0 \\
\hline $\mathrm{Temperature}$ & ${ }^{\circ} \mathrm{C}$ & 25 \\
\hline $\mathrm{Ca}$ & $\mathrm{mg} / \mathrm{L}$ & 412.3 \\
\hline $\mathrm{Mg}$ & $\mathrm{mg} / \mathrm{L}$ & 1291.8 \\
\hline $\mathrm{Na}$ & $\mathrm{mg} / \mathrm{L}$ & 10768 \\
\hline $\mathrm{K}$ & $\mathrm{mg} / \mathrm{L}$ & 399.1 \\
\hline $\mathrm{Cl}$ & $\mathrm{mg} / \mathrm{L}$ & 19353 \\
\hline $\mathrm{Alkalinity}$ & $\mathrm{mg} / \mathrm{L}$ & 2712 \\
\hline $\mathrm{SO} 4$ & & 141.7 \\
\hline
\end{tabular}

\subsubsection{Testing methodology}

The simulation for the fresh-seawater mixing model was divided into 2 steps. In order for the model to represent the Floridan aquifer geochemistry, the freshwater was firstly equilibrated with calcite under the assumption that the freshwater in the Florida aquifer equilibrates with calcite bedrocks (simulation step 1). The fresh groundwater saturated with calcite was then called "carbonate groundwater" (Barlow and Richard, 2010; Tibbals, 1990). The carbonate groundwater was then mixed in fresh-seawater model simulation ( simulation step 2). 
- $\quad$ Step 1: Carbonate groundwater simulation

The first step of simulation represented the equilibrium dissolution of calcite bedrock by the fresh groundwater. Geologically, the groundwater in this area underlies the calcite bedrocks. Upon their contacting, the dissolution of calcite by groundwater occurs, and become carbonate groundwater. The reaction equation of calcite dissolution/precipitation used in the model is shown in equation 42 .

$$
\mathrm{CO}_{2}(\mathrm{~g})+\mathrm{H}_{2} \mathrm{O}+\mathrm{CaCO}_{3} \leftrightarrow \mathrm{Ca}^{2+}+2 \mathrm{HCO}_{3}^{-}
$$

The carbonate groundwater simulation was defined by equilibrating freshwater (the average value in Table 33) with calcite (to yield the saturation index of calcite, $\mathrm{SI}_{\mathrm{cc}}=0$ ). Equation 42 indicates that an increase of $\mathrm{CO}_{2}$ results in dissolution of $\mathrm{CaCO}_{3}$. When removing $\mathrm{CO}_{2}$ from the water, the reaction goes to the left (Eq. 42), which causes the precipitation of $\mathrm{CaCO}_{3}$. For this simulation, it was assumed that the partial pressure of carbon dioxide $\left(\mathrm{P}_{\mathrm{CO}_{2}}\right)$ in groundwater was $10^{-2}$ atm. (Plummer and Sprinkle, 2001). The output represented the carbonate groundwater and was used for the mixing simulation in step 2 .

- $\quad$ Step 2: Carbonate groundwater-seawater mixing simulation

The carbonate groundwater in step 1 was then used to mix with different seawater proportions varying from $0-100 \%$ in the mixtures. PHREEQC calculates the concentration in mixtures by multiplying the concentration of each element in each solution with its mixing fraction (Parkhurst, 1995), summing these numbers, and dividing by the sum of mixing fractions. For instance, Na concentration in solution 1 is $0.1 \mathrm{~mol} / \mathrm{L}$, and $0.5 \mathrm{~mol} / \mathrm{L}$ in solution 2. If the solutions 1 and 2 are mixed in the proportion of $0.2: 0.8$, then the Na concentration in the new solution is $(0.1 \times 0.2+0.5 \times 0.8) / 1=0.42$ 
$\mathrm{mol} / \mathrm{L}$. The temperature and other intensive properties of the mixture were calculated the same way as the concentration. The model calculates the change of ionic concentrations and saturation indexes (i.e. Calcite, Aragonite, Dolomite, Gypsum, etc.), as a function of ionic strength caused by seawater in the mixture.

\subsubsection{Testing results}

A. Major ion concentration as function of salinity

The results obtained from the mixing model simulations were then used to compare with the observed Coastal Floridan aquifer data collected from over 30 monitoring stations during the years 2005 and 2006. The model results of major ion concentrations, as a function of salinity, were plotted against the observed data in Figure 14. The complete observed Coastal Floridan aquifer quality database and the selected monitoring station locations are shown in Appendix D.

In Figure 14 the observed data are represented by blue circles; the model results are shown in black lines. Figure 14 clearly shows that the salinity and major ion concentrations are linearly related, for both observed data and model results, with the coefficient of determinations, $\mathrm{R}^{2}$, greater than 0.8 . The model results for $\mathrm{Na}, \mathrm{Mg}, \mathrm{K}$ and $\mathrm{Cl}$ ions showed similar trends and correlation to the observed data; lower $\mathrm{R}^{2}$ were obtained for the $\mathrm{Ca}$ and $\mathrm{SO}_{4}$ ions. 


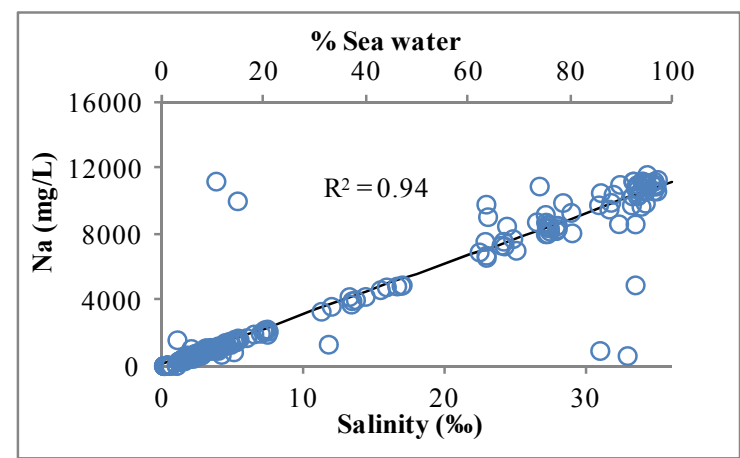

(a)

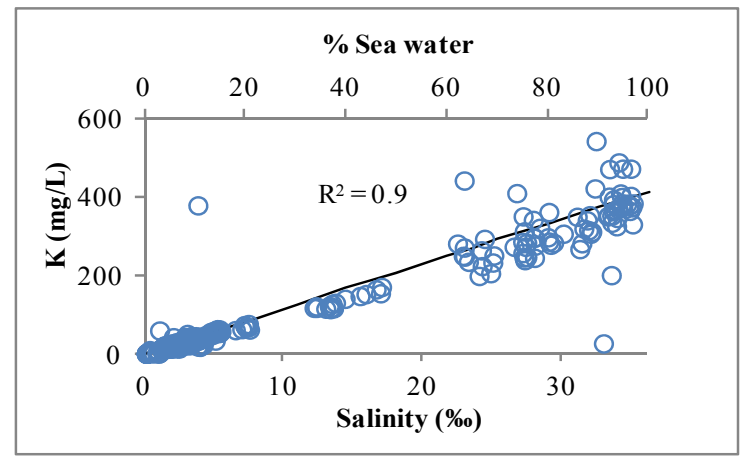

(c)

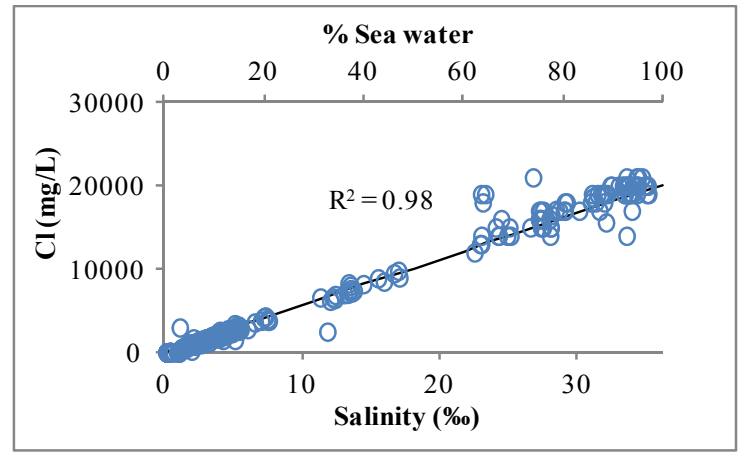

(e)

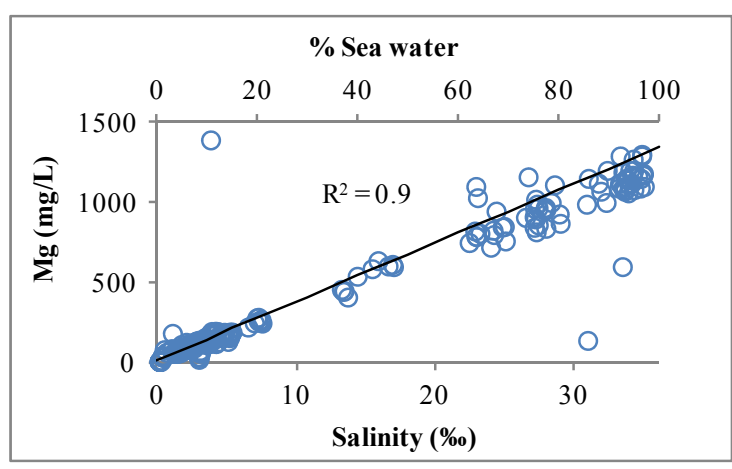

(b)

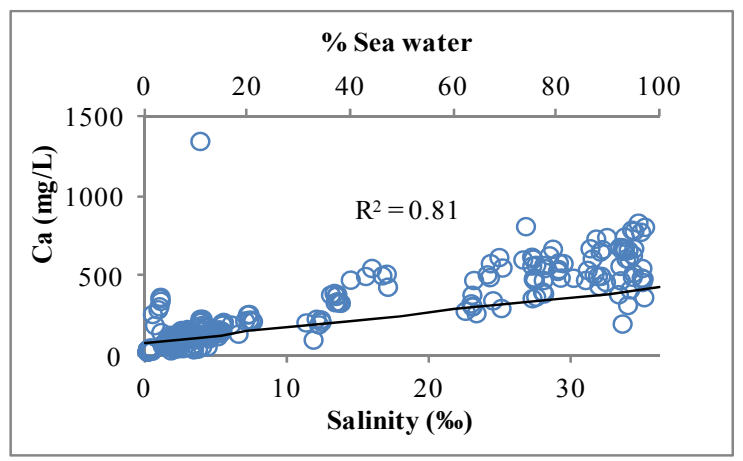

(d)

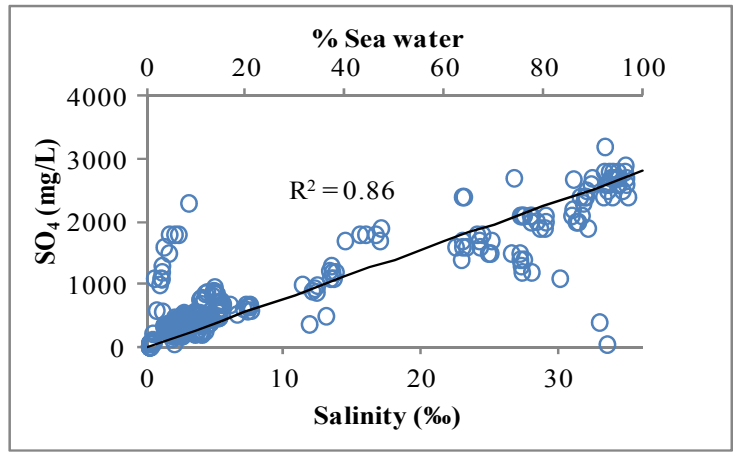

(f)

Figure 14 Comparison of major ion concentrations as a function of salinity in the mixtures between observed data collected from DBHYDRO (dots) and model results (lines); (a) $\mathrm{Na}$, (b) $\mathrm{Mg}$, (c) $\mathrm{K}$, (d) $\mathrm{Ca}$, (e) $\mathrm{Cl}$ and (f) $\mathrm{SO}_{4}$

B. Saturation indexes with salinity

A $P_{\mathrm{CO}_{2}}=10^{-2}$ was assumed for the mixing model. $P_{\mathrm{CO}_{2}}$ in groundwater is one of the important factors that influences the change in water $\mathrm{pH}$ and the dissolution and 
precipitation of carbonate minerals. Assuming $P_{\mathrm{CO}_{2}}=10^{-2}$ simulated a water $\mathrm{pH}$ that was comparable to the observed value the low seawater percentages (Figure 15). However, the water $\mathrm{pH}$ decreased at higher percentage of seawater, which did not match as well as in the case of the lower salinity fractions. A possible explanation is that ion-exchange occurs at high seawater percentages (referred to Ca concentration in Figure 15) which releases vast $\mathrm{Ca}^{2+}$ into the solution. Some of the $\mathrm{Ca}^{2+}$ may react with $\mathrm{HCO}_{3}^{-}$causing $\mathrm{CaCO}_{3}$ and $\mathrm{CO}_{2}(\mathrm{~g})$, thus, the water $\mathrm{pH}$ decreases.

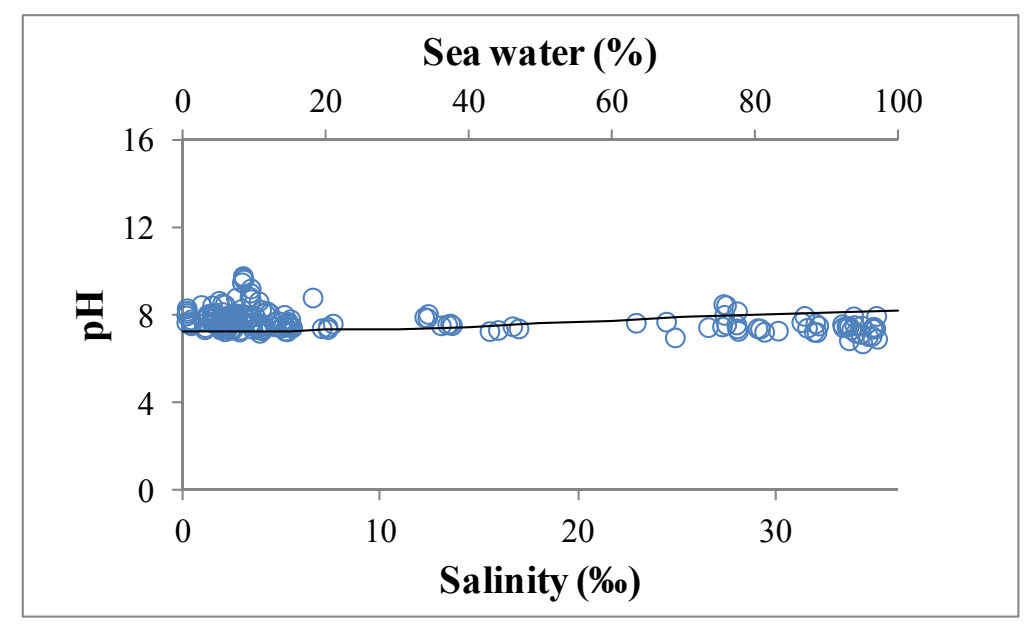

Figure 15 Water $\mathrm{pH}$ in the Floridan aquifer (open circles) for the sample collected during 2005 and 2006. The theoretical water $\mathrm{pH}$ (solid line) was calculated by PHREEQC model

The PHREEQC model was used to calculate the saturation indexes of Aragonite $\left(\mathrm{CaCO}_{3}\right)$, Calcite $\left(\mathrm{CaCO}_{3}\right)$, Dolomite $\left(\mathrm{CaMg}\left(\mathrm{CO}_{3}\right)_{2}\right)$, Halite $(\mathrm{NaCl})$, Gypsum $\left(\mathrm{CaSO}_{4}\right)$, and Magnesite $\left(\mathrm{MgCO}_{3}\right)$ of the ground-seawater mixing process. The results from the model were plotted against the seawater proportion and salinity in the mixture and compared to the calculated saturation indexes of observed data (Figure 16). 


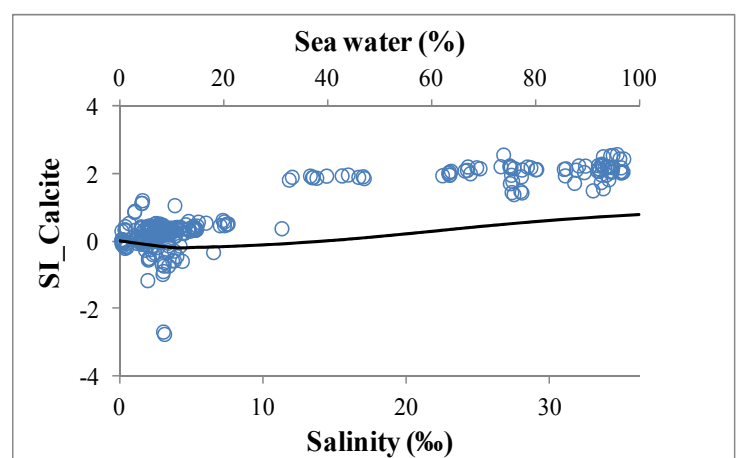

(a)

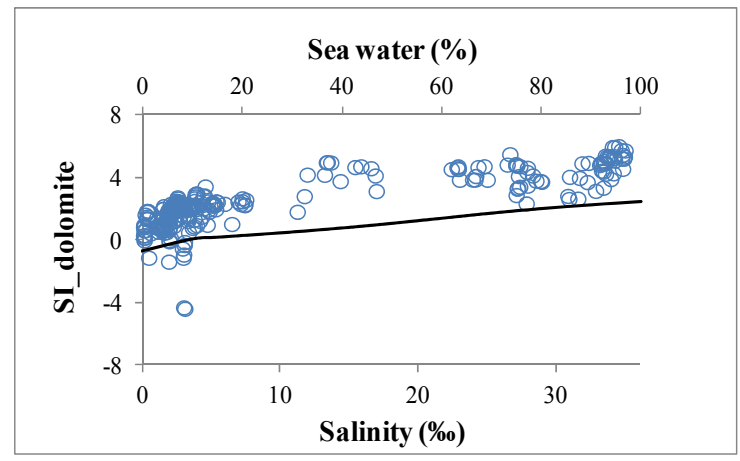

(c)

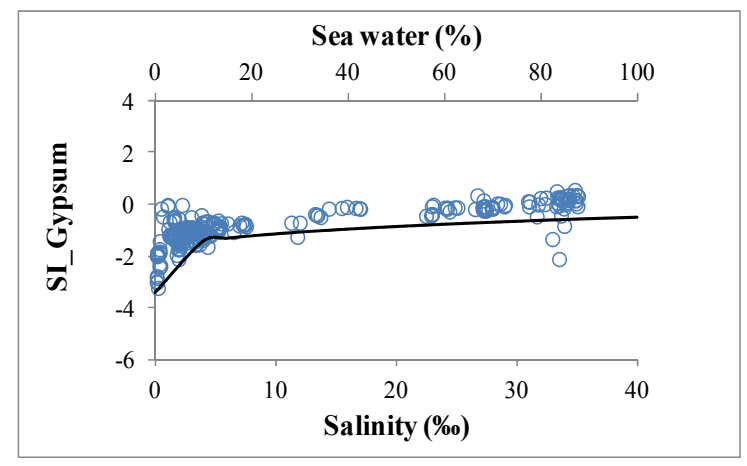

(e)

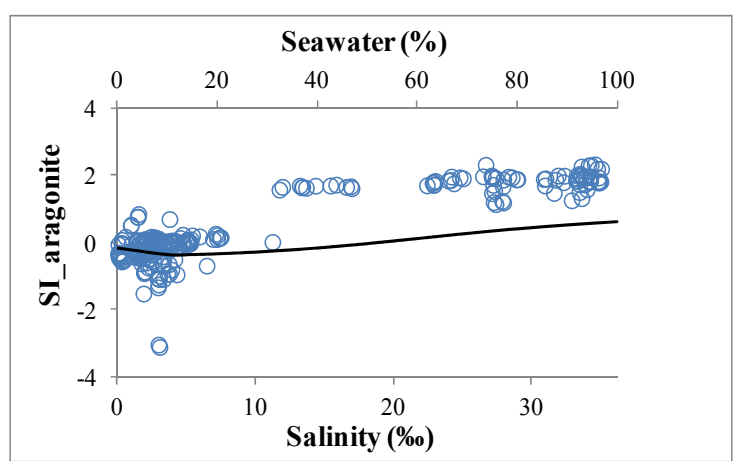

(b)

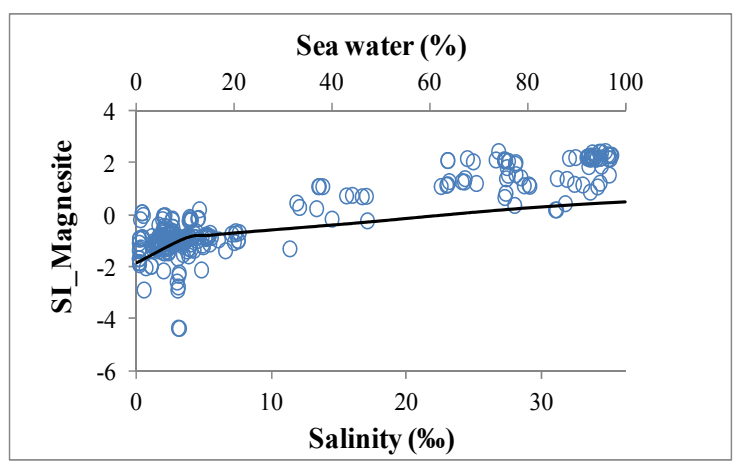

(d)

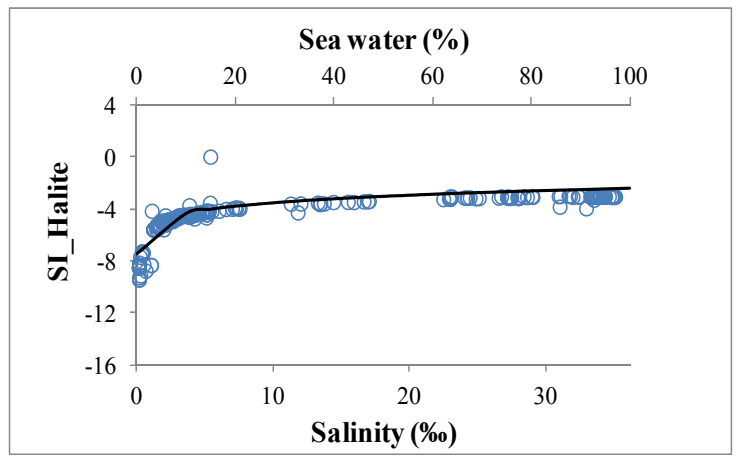

(f)

Figure 16 Various minerals saturation indexes (a) Calcite; (b) Aragonite; (c) Dolomite; (d) Magnesite; (e) Gypsum; (f) Halite, observed data (dots) and model result (lines)

The mixing model results of calcite and aragonite saturation indexes in Figure 16 show the SI $<0$ for the mixture containing $10-20 \%$ of seawater. This indicates that there is dissolution of these minerals. The model results were comparable with the observed 
data at this point $(<20 \%$ seawater). Differences between the observed data and the model predictions of saturation indexes occurred at seawater percentages greater than $20 \%$; the model underpredicted, for those minerals were not as oversaturated as expected from observed data. An explanation is non-conservative behavior of calcite dissolution, ionexchange, and $\mathrm{CO}_{2}$ flux (Stoessell et al., 1989; Price et al., 2006).

The saturation state of dolomite and magnesite showed similar behavior to calcite and aragonite; big differences between observed data and the model results occurred for seawater proportion greater than $20 \%$. However, the oversaturation of dolomite was found for all seawater percentages, while the under-saturation of magnesite is found in the mixtures containing seawater less than $20 \%$. In reality the deposit of dolomite is kinetically favored, which also depends on the ratio of $[\mathrm{Mg}]:[\mathrm{Ca}]$ and the change of $P_{\mathrm{CO} 2}$ (Pulido-Leboeuf, 2004). One basic condition that is required for the occurrence of dolomite deposition is that the ratio of $[\mathrm{Mg}]$ to $[\mathrm{Ca}]$ should be greater than 1(Margaritz et al., 1980), which was found for all the seawater proportion in Floridan aquifer. Nevertheless, the dolomitization is very much influenced by $P_{\mathrm{CO}_{2}}$. Change in $\mathrm{CO}_{2}$ flux by the respiration or the microbial metabolism affect the dolomitization. Thus the dissolution and precipitation of dolomite in Floridan aquifer may not happen thermodynamically as in Figure 16. A further investigation on dolomitization in Floridan aquifer is needed.

Gypsum saturation indexes in Figure 16 showed the same trends for both the observed data and the model results. Both results indicated the undersaturation of gypsum for all seawater proportions. Nevertheless, the saturation index of observed data was found slightly higher than that from the theoretical model. This indicated the presence of 
$\mathrm{SO}_{4}$ sources other than seawater. Samborska and Halas (2010) reported that the sources of $\mathrm{SO}_{4}$ in carbonate aquifers could be from the de-dolomitization process (equation 43) (Plummer et al., 1990) and the dissolution of pyrite (equations 44-45) (Stumm and Morgan, 1996, Banks et al., 1996).

$$
\begin{aligned}
& 1.8 \mathrm{CaSO}_{4}+0.8 \mathrm{CaMg}\left(\mathrm{CO}_{3}\right)_{2}=1.6 \mathrm{CaCO}_{3}+\mathrm{Ca}^{2+}+0.8 \mathrm{Mg}^{2+}+1.8 \mathrm{SO}_{4}^{2-} \\
& \mathrm{FeS}_{2}+7 / 2 \mathrm{O}_{2}+\mathrm{H}_{2} \mathrm{O}=\mathrm{Fe}^{2+}+2 \mathrm{SO}_{4}^{2-}+2 \mathrm{H}^{+} \\
& \mathrm{FeS}_{2}+15 / 4 \mathrm{O}_{2}+7 / 2 \mathrm{H}_{2} \mathrm{O}=\mathrm{Fe}(\mathrm{OH})_{3}+2 \mathrm{SO}_{4-}^{2--}+4 \mathrm{H}^{+}
\end{aligned}
$$

The co-existence of gypsum in carbonate rocks indicates the de-dolomitization that causes the dissolution of gypsum and dolomite and precipitation of calcite. Consequently, this process increases the concentrations of $\mathrm{Ca}, \mathrm{Mg}$ and $\mathrm{SO}_{4}$ ions in the solution, which could be a reason for the concentrations of these ions exceeding those predicted by the theoretical model. One possible source of $\mathrm{SO}_{4}$ ion could be from the dissolution of pyrite which cannot be rejected, since there are some studies (Pichler et al., 2011) that reported the occurrence of pyrite dissolution in Floridan aquifer.

Halite saturation indexes from both observed and model results showed the undersaturation in the mixtures with all seawater proportions. However, the model gave slightly overestimated SI, especially at seawater percentages greater than $20 \%$. This could be because of the non-conservative dissolution of carbonate rocks that lead to changes in ionic strength. Thus, it affects the dissolution of halite.

\subsubsection{Testing conclusion}

The model provided good predictions on major ion concentrations as a function of salinity with $\mathrm{R}^{2}>0.9$ for $\mathrm{Na}, \mathrm{Mg}, \mathrm{K}$ and $\mathrm{Cl}$. For $\mathrm{Ca}$ and $\mathrm{SO}_{4}$ concentrations, the 
correlation of $\mathrm{R}^{2}>0.8$, is obtained. It leads to the possible presence of $\mathrm{Ca}$ and $\mathrm{SO}_{4}$ sources other than seawater and their minerals. The prediction of saturation indexes is comparable to observed data. Overall, the enhanced model shows good potential to be used to calculate the major ion reactions in wide ranges of ionic strength. This confirms that the enhanced model is capable and can be employed to predict the $\mathrm{Hg}$ reactions in water.

\subsection{Process Confirmation in Transport Mode - Field Scale}

\subsubsection{Testing Scenario 1: Testing the Fate and Transport of Hg and Heavy Metals in a Groundwater Setting at Oak Ridge, TN}

This section presents the testing of enhanced PHREEQC model capability to simulate geochemical processes and coupling them to flow and transport settings. The purpose was to explore the potential of the model to assess the fate and transport of a group of heavy metals in a groundwater field site; the site is located at the Y-12 National Security Complex (NSC) in Oak Ridge, Tennessee. Historical data show that more than 200 tons of $\mathrm{Hg}$ from this $\mathrm{Y}-12$ atomic plant were released into the surrounding environment during operations in the 1950s (Brooks and Southworth, 2011). Studies have also shown that metals accumulated in the soil, rock, and groundwater of the site consequentially became sources of contamination to nearby rivers and creeks (e.g., East Fork Poplar Creek, Bear Creek) (AJA technical services, inc. 1998). For instance, mercury $(\mathrm{Hg})$, zinc $(\mathrm{Zn})$, cadmium $(\mathrm{Cd})$ and lead $(\mathrm{Pb})$ have been found and reported on the site groundwater (Brooks and Southworth, 2011; Dong et al., 2010; Loar et al., 2011; and Stewart et al., 2009). The site is reported to have a $\mathrm{Ca}-\mathrm{Mg}-\mathrm{HCO}_{3}$ groundwater type. 
In this study, ion exchange and surface complexation reactions were hypothesized to be the dominant reactions of the study of metals in groundwater transport at this site. A previous study documented that ion exchange and precipitation were the major reactions that affected the change of ionic species, along with rock weathering, for this site (Toran and Saunders, 1999). The approach herein uses the enhanced PHREEQC model to couple the geochemical and transport components to verify the possible role of ion exchange and surface complexation in the groundwater transport of the selected metals by comparison to observed concentrations.

\subsubsection{Testing site}

The geology and hydrology as well as the groundwater quality data at Oak Ridge Y-12 plant were obtained from five existing core holes (GW 131 to GW 135). These core holes were instrumented with multiport monitoring systems at depths of $60-300 \mathrm{~m}$ below land surface within Bear Creek Valley (Dreier et al., 1993). Four of the core holes (GW132 through GW-135) are along Bear Creek Valley and Chestnut Ridge on the western end of the Y-12 plant. The fifth core hole, GW-131, is located along the geologic strike with GW-135 on Chestnut Ridge near the eastern end of Y-12 plant (Figure 17). The prevailing direction of the groundwater flow along the valley is from the west to the east (Figure 18, from GW-135 to GW-131) (Dreier et al., 1993). The distance between GW135 and GW-131 is $2414 \mathrm{ft}$. or $736 \mathrm{~m}$. 


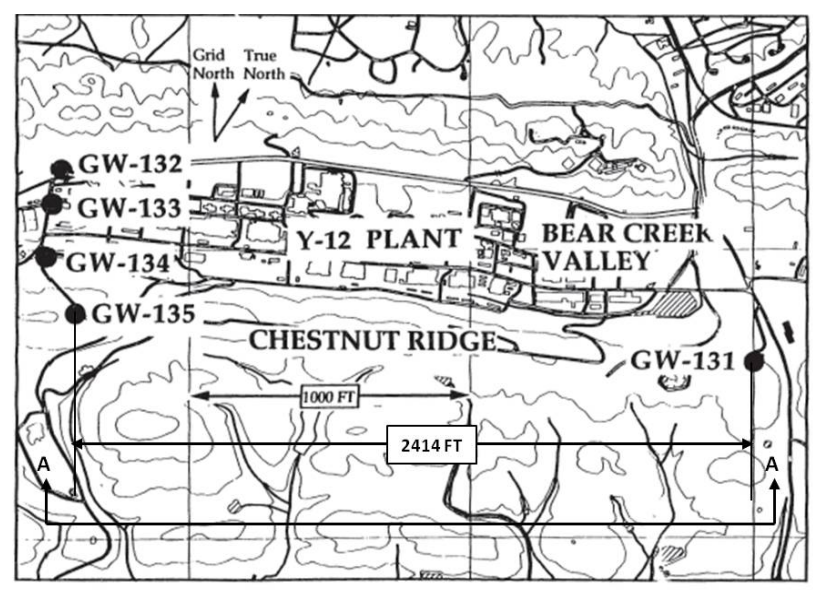

Figure 17 Study area location of the five core holes and of the section A-A between GW131 and GW-135 at Y-12 plant, Oak Ridge, Tennessee (Dreier et al., 1993)

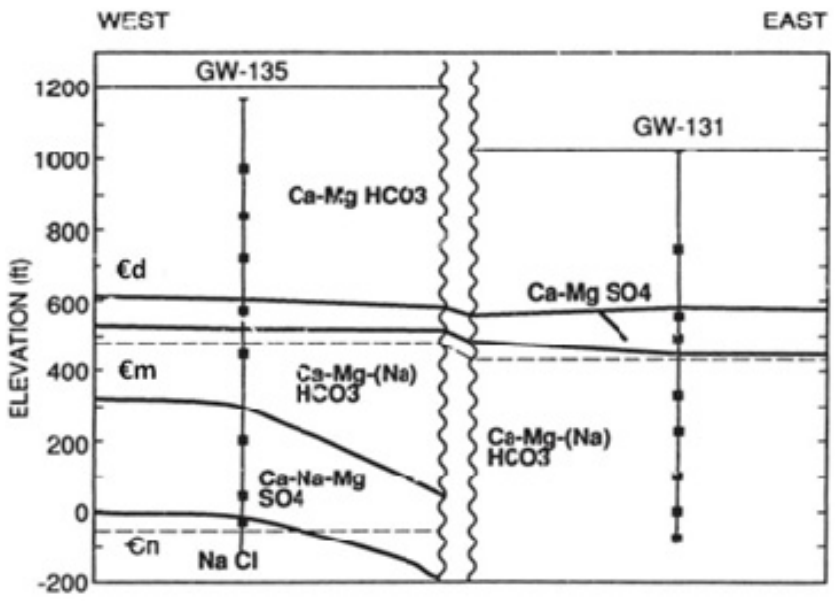

Figure 18 Profile, is strike-parallel section, shows hydrology and geology for core holes GW-131 and GW-135 where $€ \mathrm{~d}$ is Copper Ridge Dolomite, $€ \mathrm{~m}$ is Maynardville Limestone, and $€ \mathrm{n}$ is Nolichucky Shale (obtained from Dreier et al., 1991; and Toran and Saunde, 1999)

The study focuses on the flow in the saturated zone, between the water table and intermediate intervals level (depths of about $300 \mathrm{ft}$. or $91.5 \mathrm{~m}$.) (Jago et al., 1995). At these depths, the groundwater lay on the Copper Ridge Dolomite where the background water is classified as $\mathrm{Ca}-\mathrm{Mg} \mathrm{HCO}_{3}$ water type (Toran and Saunders, 1995; Dreier et al., 1993). The water quality at GW-135 is shown in Table 35 and was input to define the groundwater quality background characteristics. 
Table 35 Analysis of groundwater at core hole GW-135, Oak Ridge, TN (Dreier et al., 1993)

\begin{tabular}{|c|c|c|}
\hline Parameters & Units & Value \\
\hline $\mathrm{pH}$ & - & $8.0-8.4$ \\
\hline Temperature & ${ }^{\circ} \mathrm{C}$ & 20.2 \\
\hline K & $\mathrm{mg} / \mathrm{L}$ & $0.61-0.88$ \\
\hline $\mathrm{Na}$ & $\mathrm{mg} / \mathrm{L}$ & $0.37-0.58$ \\
\hline $\mathrm{Mg}$ & $\mathrm{mg} / \mathrm{L}$ & $17-22$ \\
\hline $\mathrm{Ca}$ & $\mathrm{mg} / \mathrm{L}$ & $28-33$ \\
\hline $\mathrm{Cl}$ & $\mathrm{mg} / \mathrm{L}$ & $1-2$ \\
\hline $\mathrm{SO}_{4}$ & $\mathrm{mg} / \mathrm{L}$ & $2-6$ \\
\hline $\mathrm{NO}_{3}$ & $\mathrm{mg} / \mathrm{L}$ & $0.5-1$ \\
\hline $\mathrm{Fe}$ & $\mathrm{mg} / \mathrm{L}$ & $0.1-0.3$ \\
\hline $\mathrm{Hg}$ & $\mathrm{mg} / \mathrm{L}$ & $0.00086-0.0066$ \\
\hline $\mathrm{Pb}$ & $\mathrm{mg} / \mathrm{L}$ & $0.004-0.006$ \\
\hline $\mathrm{Zn}$ & $\mathrm{mg} / \mathrm{L}$ & $0.013-0.022$ \\
\hline $\mathrm{Cd}$ & $\mathrm{mg} / \mathrm{L}$ & $0.0031-0.059$ \\
\hline
\end{tabular}

\subsubsection{Methodology}

\section{A. Simulations in 1-D transport}

The geochemical model PHREEQC coupled to a one-dimensional (i.e.,1-D) transport algorithm was used to assess the heavy metal contaminations fate and transport from a starting core hole (GW-135) to the destination point (GW-131) (Figures and Figure 18). 
The travel distance between GW-135 and GW-131 is $736 \mathrm{~m}$ (or $2414 \mathrm{ft}$.). The average groundwater pore velocity was reported to be up to $0.66-1.00 \mathrm{~m} /$ day (Jago et al., 1995). An average velocity of $0.66 \mathrm{~m} /$ day and a dispersion coefficient $D_{L}$ of $0.066 \mathrm{~m}^{2} / \mathrm{d}$ were judged appropriate to be used in the transport simulations at the depths of interest (Jago et al., 1995).

Initial conditions were defined by the water quality characteristics at core hole GW-135 for major ions, heavy metals of concerns, $\mathrm{pH}$ and temperature. A constant-flux type-three boundary condition was used to define as the boundary condition at GW-135 in the simulations. PHREEQC then calculated the change in aqueous chemistry (dissolution-precipitation, speciation, ion exchange, and sorption) along the travel distance based on an ion-association model for two scenarios: a) ion-exchange only (with major cations) and b) ion-exchange with sorption reaction on $\mathrm{Fe}(\mathrm{OH})_{3}$.

B. Ion exchange

At this site, the exchange capacity (CEC) of the dolomite and quartz rich sediment is about 39 meq/kg (Appelo and Postma, 2005; and Vertacnik et al., 1997), while the bulk density $\left(\rho_{b}\right)$ and the porosity $(\theta)$ of the used in this paper are, respectively, $1.67 \mathrm{~g} / \mathrm{cm}^{3}$ and 0.5 (Dreier et al., 1993). Converting CEC to a constant volume ( $\mathrm{mmol} / \mathrm{kg}$ to $\mathrm{mmol} / \mathrm{L})$ facilitates comparison with the quantities of elements in the pore solution and mass transfer associate with reaction and transport through the groundwater. The CEC of 39 $\mathrm{meq} / \mathrm{kg}$ soil can be converted to $130 \mathrm{mmol} / \mathrm{L}$ of pore water using equation 46 (Appelo and Postma, 2005):

$$
C E C\left(\frac{m e q}{k g}\right) \times \frac{\rho_{b}}{\theta}\left(\frac{g}{c^{3}}\right)=C E C\left(\frac{m e q}{L}\right)
$$


The exchange reaction equations used in this study included $\mathrm{Ca}$ and $\mathrm{Mg}$, which were assumed to occupy $100 \%$ of all exchanged sites. The exchange reactions for $\mathrm{Ca}-\mathrm{I}$ and $M g-I$, where I represents any cation with i valence state, are presented in equations 47 and 48 .

$$
\begin{aligned}
& C a^{2+}+\frac{2}{i} I-X_{i}^{-} \leftrightarrow C a-X_{2}+\frac{2}{i} \cdot I_{i}^{+} ; K_{C a / I} \\
& M g^{2+}+\frac{2}{i} I-X_{i}^{-} \leftrightarrow M g-X_{2}+\frac{2}{i} \cdot I_{i}^{+} ; K_{M g} / I
\end{aligned}
$$

The exchange reactions and exchange coefficients relative to $\mathrm{Ca}^{2+}$ and $\mathrm{Mg}^{2+}$ after the Gaines-Thomas convention (Bruggenwert and Kamphorst, 1979) are shown in Table 36.

Table 36 Exchange reaction equations and coefficients for $\mathrm{Ca}$ and $\mathrm{Mg}$ (Appelo and Postma, 2005; Bruggenwert and Kamphorst, 1979; and Stumm and Morgan, 1996)

\begin{tabular}{|cc|}
\hline Reaction & Coefficients (K) \\
\hline $\mathrm{Ca}^{2+}+\mathrm{Hg}-\mathrm{X}_{2} \leftarrow \rightarrow \mathrm{Ca}-\mathrm{X}_{2}+\mathrm{Hg}^{2+}$ & $\mathrm{K}_{\mathrm{CaHg}}=0.25$ \\
\hline $\mathrm{Ca}^{2+}+\mathrm{Zn}-\mathrm{X}_{2} \leftarrow \rightarrow \mathrm{Ca}-\mathrm{X}_{2}+\mathrm{Zn}^{2+}$ & $\mathrm{K}_{\mathrm{CaZn}}=1.00$ \\
\hline $\mathrm{Ca}^{2+}+\mathrm{Pb}-\mathrm{X}_{2} \leftarrow \rightarrow \mathrm{Ca}-\mathrm{X}_{2}+\mathrm{Pb}^{2+}$ & $\mathrm{K}_{\mathrm{CaPb}}=0.75$ \\
\hline $\mathrm{Ca}^{2+}+\mathrm{Cd}-\mathrm{X}_{2} \leftarrow \rightarrow \mathrm{Ca}-\mathrm{X}_{2}+\mathrm{Cd}^{2+}$ & $\mathrm{K}_{\mathrm{CalCd}}=1.00$ \\
\hline $\mathrm{Ca}^{2+}+\mathrm{Mg}-\mathrm{X}_{2} \leftarrow \rightarrow \mathrm{Ca}-\mathrm{X}_{2}+\mathrm{Mg}^{2+}$ & $\mathrm{K}_{\mathrm{CalMg}}=1.25$ \\
\hline $\mathrm{Mg}^{2+}+\mathrm{Hg}-\mathrm{X}_{2} \leftarrow \rightarrow \mathrm{Mg}-\mathrm{X}_{2}+\mathrm{Hg}^{2+}$ & $\mathrm{K}_{\mathrm{Mg} \mathrm{Hg}}=0.20$ \\
\hline $\mathrm{Mg}^{2+}+\mathrm{Zn}-\mathrm{X}_{2} \leftarrow \rightarrow \mathrm{Mg}-\mathrm{X}_{2}+\mathrm{Zn}^{2+}$ & $\mathrm{K}_{\mathrm{MgZn}}=0.80$ \\
\hline $\mathrm{Mg}^{2+}+\mathrm{Pb}-\mathrm{X}_{2} \leftarrow \rightarrow \mathrm{Mg}-\mathrm{X}_{2}+\mathrm{Pb}^{2+}$ & $\mathrm{K}_{\mathrm{MgPb}}=0.60$ \\
\hline $\mathrm{Mg}^{2+}+\mathrm{Cd}-\mathrm{X}_{2} \leftarrow \rightarrow \mathrm{Mg}-\mathrm{X}_{2}+\mathrm{Cd}^{2+}$ & $\mathrm{K}_{\mathrm{Mg} I \mathrm{Cd}}=0.80$ \\
\hline $\mathrm{Mg}^{2+}+\mathrm{Ca}-\mathrm{X}_{2} \leftarrow \rightarrow \mathrm{Mg}-\mathrm{X}_{2}+\mathrm{Ca}^{2+}$ & $\mathrm{K}_{\mathrm{MgICa}}=0.80$ \\
\hline
\end{tabular}




\section{Sorption}

PHREEQC offers a surface complexation model to calculate the sorption of heavy metals on a mineral, which can define the mineral (i.e., ferric oxide), the available sorption sites, and the sorption equilibrium constant (K). This study used the Linear Free Energy Relations (LFER) method to calculate the sorption reaction constant for each metal of interest (Dzombak and Morel, 1990) and used a complexation reaction on $\mathrm{Fe}(\mathrm{OH})_{3}$ for two types of sites, a strong site type (i.e., $\left.\mathrm{Hfo} \_\mathrm{sOH}\right)$ and a weak type site (i.e., Hfo_wOH) (Stumm and Morgan, 1996; and Dzombak and Morel, 1990). Properties of hydrous ferric oxide were used for the model calculations. The sorption reactions and their sorption constants used in the model are presented in Table 37 (Farley et al., 1984; Stumm and Morgan, 1996; and Dzombak and Morel, 1990).

Table 37 Equations and constants of sorption reactions of ions on $\mathrm{Fe}(\mathrm{OH})_{3}$ (Farley et al., 1984; Stumm and Morgan, 1996; and Dzombak and Morel, 1990)

\begin{tabular}{|c|c|}
\hline Reactions & $\log K_{\text {ads }}$ \\
\hline $\mathrm{Hfo} \_\mathrm{sOH}+\mathrm{Ca}^{+2}=\mathrm{Hfo} \_\mathrm{SOHCa}^{+2}$ & 4.97 \\
\hline $\mathrm{Hfo} \_\mathrm{wOH}+\mathrm{Ca}^{+2}=\mathrm{Hfo}_{\mathrm{WOCa}}{ }^{+}+\mathrm{H}^{+}$ & -5.85 \\
\hline Hfo_wOH $+\mathrm{Mg}^{+2}=$ Hfo_wOMg ${ }^{+}+\mathrm{H}^{+}$ & -4.6 \\
\hline Hfo_sOH $+\mathrm{Cd}^{+2}=$ Hfo_sOCd ${ }^{+}+\mathrm{H}^{+}$ & 0.47 \\
\hline Hfo_wOH $+\mathrm{Cd}^{+2}=$ Hfo_wOCd ${ }^{+}+\mathrm{H}^{+}$ & -2.9 \\
\hline Hfo_sOH $+\mathrm{Zn}^{+2}=$ Hfo_sOZn ${ }^{+}+\mathrm{H}^{+}$ & 0.99 \\
\hline Hfo_wOH $+\mathrm{Zn}^{+2}=$ Hfo_wOZn ${ }^{+}+\mathrm{H}^{+}$ & -1.99 \\
\hline Hfo_sOH $+\mathrm{Pb}^{+2}=\mathrm{Hfo}_{-} \mathrm{SOPb}^{+}+\mathrm{H}^{+}$ & 4.65 \\
\hline Hfo_wOH $+\mathrm{Pb}^{+2}=$ Hfo_wOPb ${ }^{+}+\mathrm{H}^{+}$ & 0.3 \\
\hline Hfo_sOH $+\mathrm{Hg}^{+2}=$ Hfo_sOHg ${ }^{+}+\mathrm{H}^{+}$ & 7.98 \\
\hline Hfo_wOH $+\mathrm{Hg}^{+2}=$ Hfo_wOHg ${ }^{+}+\mathrm{H}^{+}$ & 5.87 \\
\hline
\end{tabular}




\subsubsection{Testing results}

A. Dissolved metal transport prediction with ion exchange occurrence

The concentrations of dissolved metals along the travel distance, when the effect of cation exchange capacity on the heavy metals retention is considered are shown in Figure 19. The dissolved concentrations of $\mathrm{Zn}, \mathrm{Pb}$, and $\mathrm{Cd}$ are predicted to decrease sharply within the first $100 \mathrm{~m}$, sorbing in trace amounts beyond $100 \mathrm{~m}$, while the $\mathrm{Hg}$ concentration remains quite constant over most of the entire distance between core holes but showing a decreasing trend around GW-131. The pattern of transport and the differences among the metals of interest may be explained by the lower exchange coefficients of $\mathrm{Hg}$ to $\mathrm{Ca}$ and $\mathrm{Mg}\left(\mathrm{K}_{\mathrm{Ca} \mid \mathrm{Hg}}=0.25\right.$, and $\left.\mathrm{K}_{\mathrm{Mg} \mid \mathrm{Hg}}=0.20\right)$ than those of the other metals (i.e., $\mathrm{Zn}, \mathrm{Pb}$, and $\mathrm{Cd}$ ) to $\mathrm{Ca}$ and $\mathrm{Mg}$ Table 36. Additional analyses also indicate that $\mathrm{Ca}$ and $\mathrm{Mg}$ occupy most of the exchanged sites in the rock matrix $(\sim 60 \%$ for $\mathrm{Ca}$ and $\sim 40 \%$ for $\mathrm{Mg}$ ), a dolomite bedrock (Toran and Saunders, 1999), where dissolution should

yield high concentrations of $\mathrm{Ca}$ and $\mathrm{Mg}$ in the groundwater (i.e., $\mathrm{Ca}-\mathrm{Mg}-\mathrm{HCO}_{3}$ background water type). 


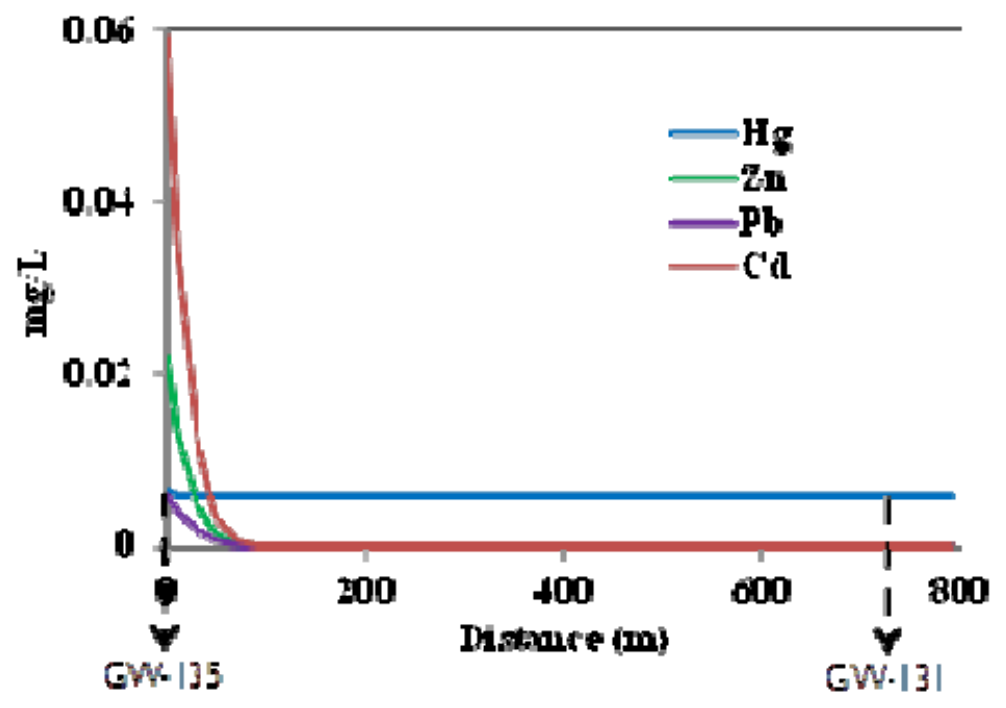

Figure 19 Effect of ion exchange on metal concentration along the distance between core holes

B. Dissolved metal transport prediction with ion exchange and sorption occurrence

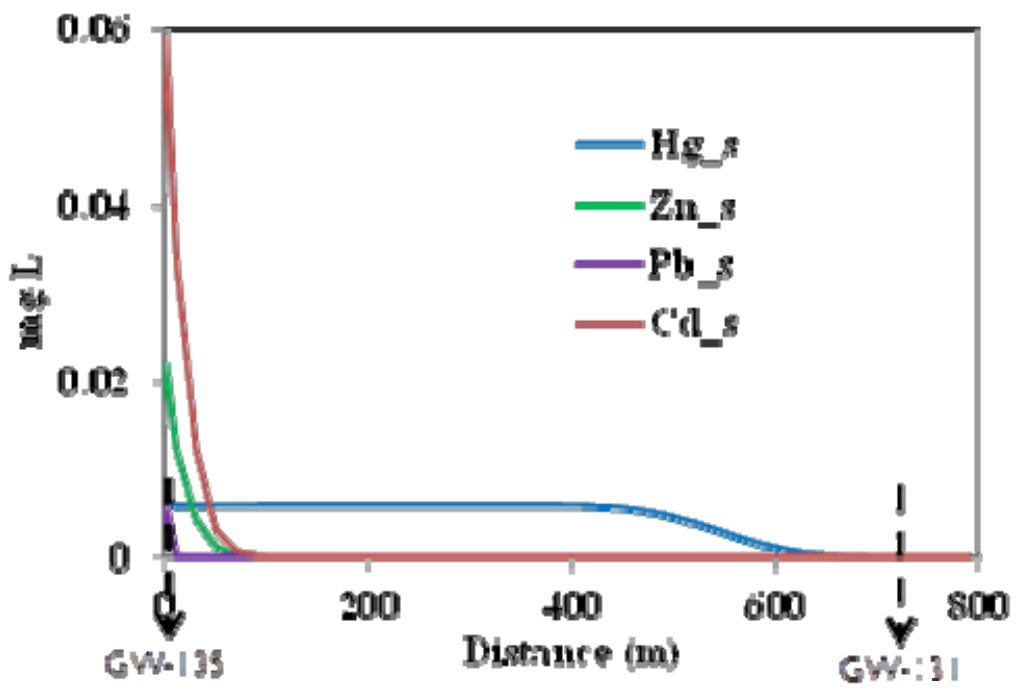

Figure 20 Effect of ion exchange and sorption on dissolved metal concentration along the distance between core holes

Figure 20 shows the concentration of heavy metal along the travel distance when ion exchange is simulated simultaneously with the sorption on the precipitated $\mathrm{Fe}(\mathrm{OH})_{3}$. The 
results show that the presence of precipitated $\mathrm{Fe}(\mathrm{OH})_{3}$ may trigger more sorption on its surface of $\mathrm{Hg}$ and $\mathrm{Pb}$ than of $\mathrm{Zn}$ and $\mathrm{Cd}$; Figure 21 shows, with more detail, the comparison between the possible role of ion exchange only and that of simultaneous ion exchange and sorption for $\mathrm{Hg}$ and $\mathrm{Pb}$ along the distance between the core holes.
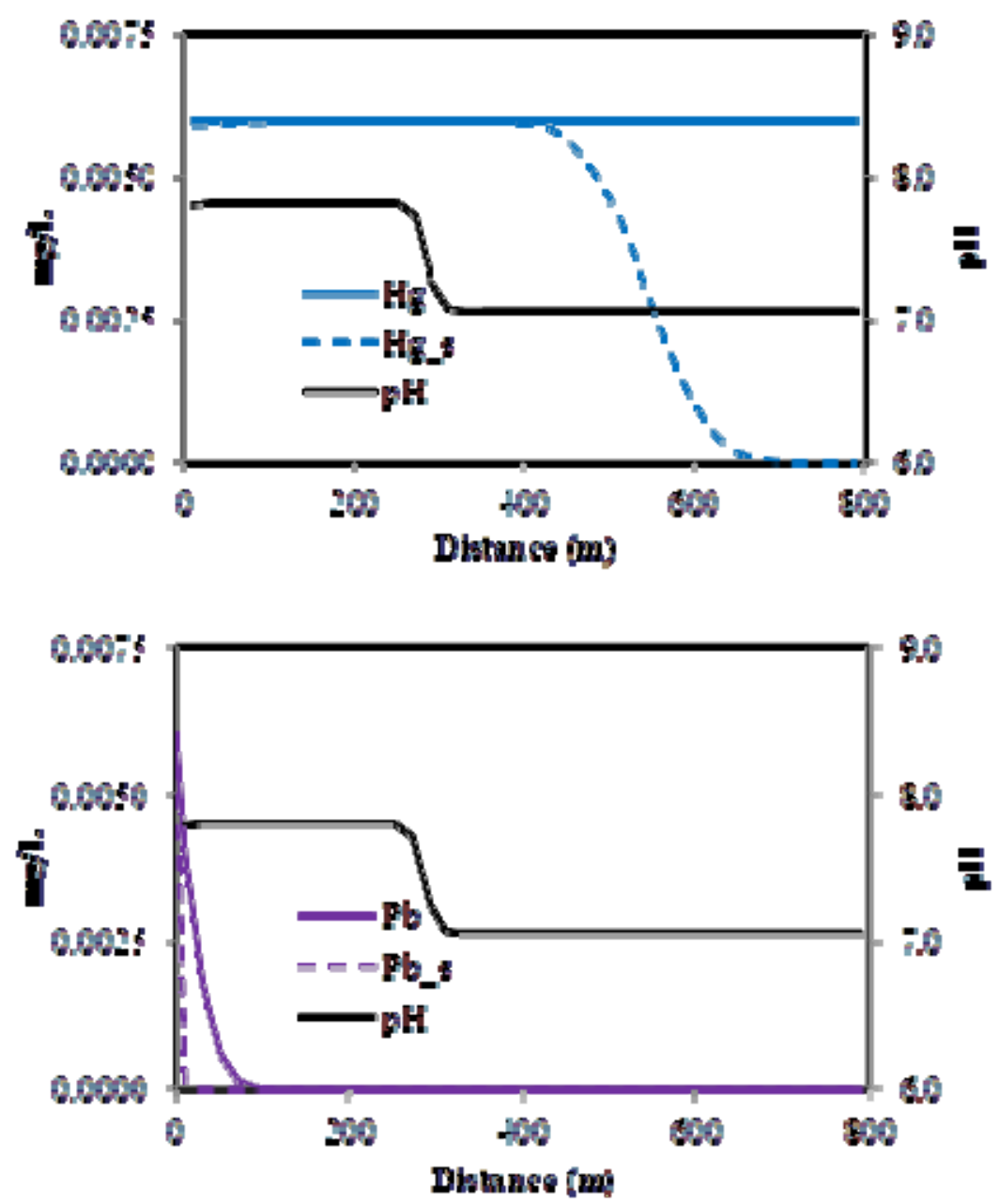

Figure 21 Dissolved metal concentrations, (a) $\mathrm{Hg}$; and (b) $\mathrm{Pb}$ and $\mathrm{pH}$ profiles along the distance between core holes: only ion exchange model (dashed line) and ion exchange with sorption on $\mathrm{Fe}(\mathrm{OH})_{3}$ (solid line)

The lower predicted concentrations of $\mathrm{Zn}$ and $\mathrm{Cd}$ may be explained by their much smaller sorption-reaction constants on $\mathrm{Fe}(\mathrm{HO})_{3}$ (i.e., $\log \mathrm{K}$ is 0.99 for $\mathrm{Zn}$ and 0.47 for $\mathrm{Cd}$ ) than those of $\mathrm{Hg}(\log \mathrm{K}=7.98)$ and $\mathrm{Pb}(\log \mathrm{K}=4.65)(\mathrm{Zhu}, 2002$; and Morel and Hering, 
1993). The latter difference is expected to specially occur when limited amounts of sorbent are available, which results in competition between metals with high sorption constants, such as those of $\mathrm{Hg}$ and $\mathrm{Pb}$, and those with low constants such as $\mathrm{Zn}$ and $\mathrm{Cd}$.

\section{Field verification of simulation scenarios}

An attempt was made to verify the role of ion exchange and sorption, for the initial and boundary conditions of the simulations, using limited water quality data at GW-131 (Dreier et al., 1993). The estimated change in dissolved metal concentrations, with distance between GW-135 and GW-131for the case of simultaneous ion exchange and sorption, and the available water quality measurements at GW-131 are tabulated in Table 38.

The predictions of dissolved concentrations at the location of core hole GW-131 are found to be, within reported ranges, for all major ions, below limits of detection for the metals of interest, and for $\mathrm{pH}$. Available measurements are however not sufficient to satisfactorily verify the hypothesized scenarios of process dominance in the field setting, but they do provide an encouraging indication of the potential of the modeling approach to simulate field conditions. Clearly, an appropriate plan for measurements of both flow and transport parameters and water quality constituents is needed to enhance the opportunity for reasonable field verification. A reasonable verification should provide a tool that can be used for that site with a higher level of confidence. 
Table 38 Predicted and measured groundwater quality between core holes GW-135 and GW-131, Oak Ridge, TN (concentrations in mg/L)

\begin{tabular}{|ccccccc|}
$\begin{array}{c}\text { Distance } \\
(\mathbf{m})\end{array}$ & $\begin{array}{c}\text { Observed data at } \\
\text { GW 135 }\end{array}$ & \multicolumn{2}{c}{ Calculated Data } & & $\begin{array}{c}\text { Observed data } \\
\text { at GW 131 }\end{array}$ \\
\hline Parameters & $\mathbf{0}^{\mathbf{a}}$ & $\mathbf{5 0}$ & $\mathbf{2 5 0}$ & $\mathbf{5 0 0}$ & $\mathbf{7 3 6}$ & $\mathbf{7 3 6}^{\mathrm{a}}$ \\
\hline $\mathrm{pH}$ & $8.0-8.4$ & 7.54 & 7.4 & 7.3 & 7.1 & $7.0-7.9$ \\
\hline $\mathrm{K}$ & $0.61-0.88$ & & & & 0.82 & $0.73-9.9$ \\
\hline $\mathrm{Na}$ & $0.37-0.58$ & 0.57 & 0.32 & 0.38 & 0.37 & $0.1-110$ \\
\hline $\mathrm{Mg}$ & $17-22$ & 18.4 & 17.6 & 18.7 & 20 & $18-110$ \\
\hline $\mathrm{Ca}$ & $28-33$ & 29.8 & 29 & 30.04 & 33 & $30-190$ \\
\hline $\mathrm{SO} 4$ & $2-700$ & 183 & 163 & 142 & 155 & $4-170$ \\
\hline $\mathrm{NO}$ & $1-10$ & 5.01 & 4.02 & 4.38 & 4.43 & $2-10$ \\
\hline $\mathrm{Hg}$ & $8.6 \times 10^{-4}-6.6 \times 10^{-3}$ & 0.0059 & 0.0059 & 0.0042 & $1.3 \times 10^{-6}$ & $<0.0002^{\mathrm{b}}$ \\
\hline $\mathrm{Pb}$ & $0.004-0.006$ & $3.3 \times 10^{-10}$ & $5.5 \times 10^{-19}$ & $7.1 \times 10^{-23}$ & $\sim 0.00$ & $<0.004^{\mathrm{b}}$ \\
\hline $\mathrm{Zn}$ & $0.013-0.022$ & 0.001 & $7.1 \times 10^{-19}$ & $2.4 \times 10^{-22}$ & $\sim 0.00$ & $<0.002^{\mathrm{b}}$ \\
\hline $\mathrm{Cd}$ & $0.0031-0.059$ & 0.003 & $2.08 \times 10^{-15}$ & $3.0 \times 10^{-21}$ & $\sim 0.00$ & $<0.002^{\mathrm{b}}$ \\
\hline
\end{tabular}

${ }^{a}$ Data obtained from Dreier et al. (1991)

${ }^{\mathrm{b}}$ The limited detection values

\subsubsection{Testing conclusions}

The approach herein used couples geochemical and transport components in an attempt to verify the role of ion exchange and surface complexation in the transport of the selected metals with emphasis on $\mathrm{Hg}$ in the groundwater setting at Oak Ridge, TN. Overall the simulated dissolved concentrations fall within the ranges of the reported water quality measurements, supporting previous findings that concluded ion exchange to be an important fate process at this site (Toran and Saunders; 1999). The hypothesized roles prove the capability of the enhanced PHREEQC coupled-transport model is a tool 
that can be used to simulate the hydrogeochemical transport of $\mathrm{Hg}$ in groundwater setting. 


\section{FUNDAMENTAL SCENARIOS AND ANALYSIS}

The objectives of this Chapter are to describe and utilize the enhanced model to assess the chemical and physical (fate and transport; advection, dispersion) processes of $\mathrm{Hg}$ in different scenarios. The fundamental process simulations are described herein sections 5.1 and 5.2, respectively. The model was then used to simulate the processes in transport (i.e., the coupling between chemical processes and transport) in section 5.3.

\subsection{Chemical Processes}

$\mathrm{Hg}$ chemical processes for which the thermodynamic database has herein been improved include solution and precipitation, ion-exchange, and surface complexation. These processes are described in this section.

\subsubsection{Species, Solubility, and Precipitation Processes}

PHREEQC assumes that the dissolved species are in thermodynamic equilibrium. The model then calculates the species using the added thermodynamic database. For example, the association reaction of the aqueous species is $\mathrm{Hg}(\mathrm{OH})_{2}+2 \mathrm{H}^{+}=\mathrm{Hg}^{2+}+$ $2 \mathrm{H}_{2} \mathrm{O}$. The $\log \mathrm{K}$ for this reaction at $25^{\circ} \mathrm{C}$ is 6.09 . This can be written in the form of mass-action equation (recall equation 1):

$$
10^{6.09}=\frac{\left[\mathrm{Hg}^{2+}\right]}{\left[\mathrm{Hg}(\mathrm{OH})_{2}\right]\left[\mathrm{H}^{+}\right]^{2}}
$$

PHREEQC calculates the solubility and precipitation processes based on the added thermodynamic database. It then assumes the activity of pure phase to be one and calculates the solubility and precipitation using the mass-action equation. For example, 
the solubility reaction of cinnabar is $\mathrm{HgS}=\mathrm{Hg}^{2+}+\mathrm{S}^{2-}$ with $\log \mathrm{K}$ at $25{ }^{\circ} \mathrm{C}$ of -53 , thus, mass-action equation is $10^{-53}=a_{\mathrm{Hg}^{2+}} a_{\mathrm{S}^{2-}}$. The simple schematic in Figure 22 helps to understand that at equilibrium, the model can simulate the speciation-distribution, solubility, and precipitation.

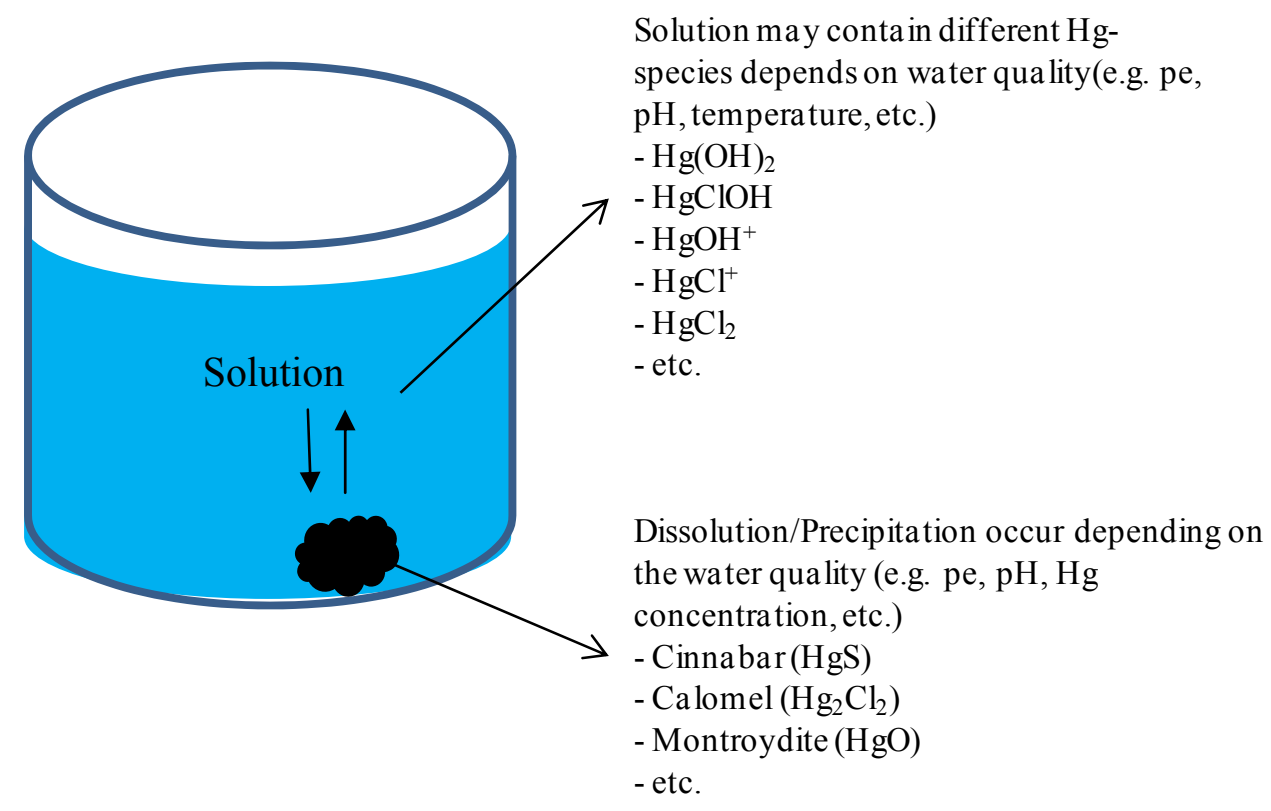

Figure 22 PHREEQC solution and precipitation process

However, the occurrence of solubility and precipitation, as well as the presence of each dissolved species, depend on many factors (e.g., pe, $\mathrm{pH}$, temperature, etc.). The sensitivity analysis of these factors with respect to the $\mathrm{Hg}$ processes is described in section 5.3. 


\subsubsection{Ion Exchange Process}

Ion exchange is a replacement process of one ion by another on the exchanger. Ion exchange is one form of sorption by which one substance becomes attached to another through the exchange of ions. The other sorption mechanisms are adsorption (the process in which the ion attaches onto the surface of a solid) and absorption (the process in which the ion attaches into the solid). For the typical aqueous environment, some examples of exchangers are soil, clay and rocks (Figure 23).

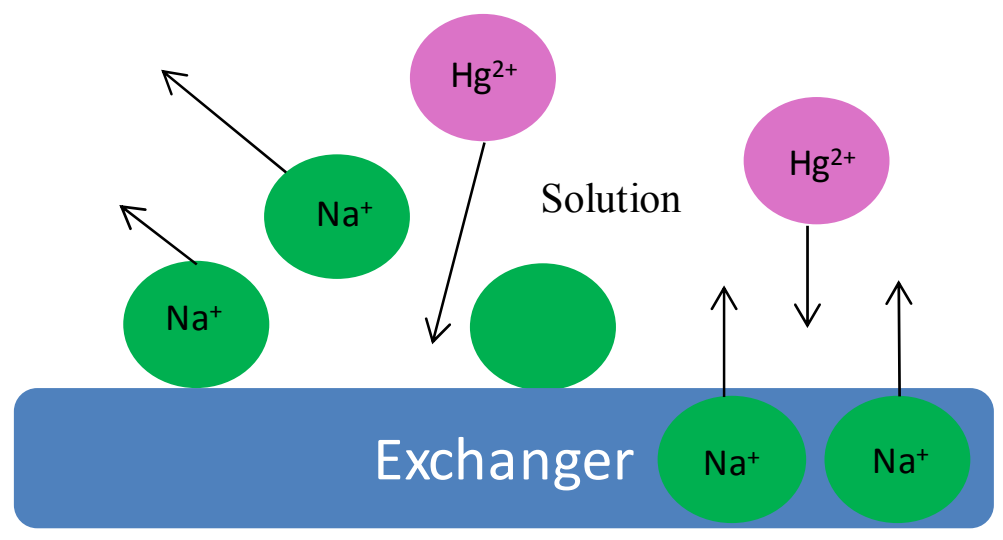

Figure 23 Ion-exchange process

PHREEQC calculates the ion-exchange species at equilibrium using the added thermodynamic database, which is expressed in the mass-action equation. For example, the association reaction for the exchange species $\mathrm{HgX}_{2}$ is $\mathrm{Hg}^{2+}+2 \mathrm{X}^{-}=\mathrm{HgX}$ with $\log \mathrm{K}$ of -1.39 .

$$
10^{-1.39}=\frac{\left[\mathrm{HgX}_{2}\right]}{\left[\mathrm{Hg}^{2+}\right]\left[\mathrm{X}^{-}\right]^{2}}
$$


From the mass-action equation of $\mathrm{HgX}_{2}$, the model calculates and solves for the amount of $\mathrm{HgX}_{2}$.

\subsubsection{Surface Complexation}

It has been mentioned earlier in this study that surface complexation is the process whereby an ion sorbs on the surface of solid surfaces. The solids are minerals, soils, rocks, etc. Figure 24 shows the surface complexation process where the ions sorb onto the solid surface. The difference between surface complexation and ion exchange processes is that surface complexation is not a replacement of ion by another ion unlike the ion exchange process.

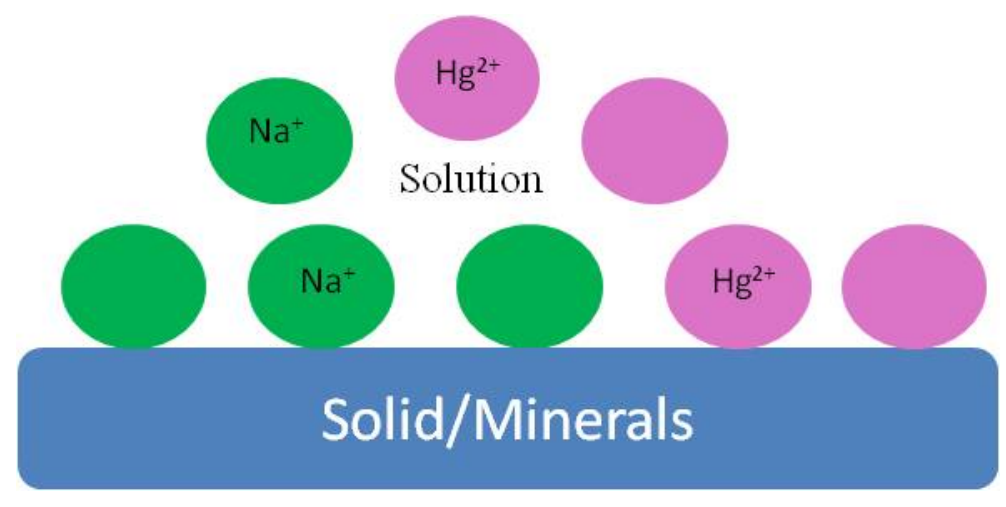

Figure 24 Surface complexation process

PHRREQC calculates the surface complexation species at equilibrium from the mass-action equation using the added thermodynamic data. For example, the ferrihydrite surface association reaction with $\mathrm{Hg}(\mathrm{OH})_{2}$ species is $\equiv \mathrm{Hfo} \_$wOH $+\mathrm{Hg}(\mathrm{OH})_{2}+\mathrm{H}^{+}=$ $\equiv$ Hfo_w ${ } \mathrm{OHg}^{+}+2 \mathrm{H}_{2} \mathrm{O}$ with $\log \mathrm{K}$ of 12.6 . The mass-action can be expressed as equation 12 (recall Eq. 12). 


$$
10^{12.6}=\frac{\left[\mathrm{Hfo}_{-} \mathrm{wOHg}^{+}\right]}{\left[\mathrm{Hfo} \mathrm{wOH}_{-}\right]\left[\mathrm{Hg}(\mathrm{OH})_{2}\right]\left[\mathrm{H}^{+}\right]} e^{-\frac{F \psi_{s}}{R T}}
$$

The amount of $\equiv \mathrm{Hfo} \_\mathrm{OHg}^{+}$species is calculated by the model using Equation 12 .

\subsection{Physical Processes}

The physical or transport process in PHREEQC consists of 2 main transport mechanisms:

1) Advection is a transport process in which flowing water transports the substances or the pollutants. The process depends on the 1) water flow velocity, and 2) direction of water flow.

2) Dispersion is a transport process that occurs as a result of concentration variations. Only the dispersion in the direction of flow or longitudinal dispersion is considered here. Dispersion coefficient is the sum of mechanical dispersion $\left(\alpha_{L} v\right)$ and diffusion $\left(D^{*}\right)$.

PHREEQC calculates the transport of a dissolved chemical by coupling chemical and physical process calculations based on the mass conservation principle (Figure 25).

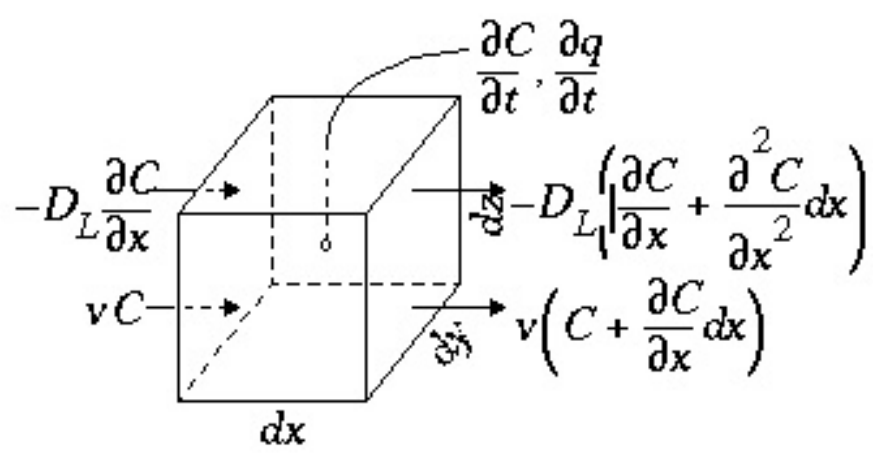

Figure 25 Mass conservation for transport process (Parkhurst and Appelo 1999) 
Figure 25 graphically depicts that the mass enters the cube from the right side ( $\mathrm{x}$ direction). As mentioned before, the mass is transported by advection and dispersion. Mass balance in the system is expressed as:

$$
\begin{gathered}
\frac{\partial C}{\partial t}=C_{\text {In }}-C_{\text {out }}-C_{\text {reaction }} \\
\frac{\partial C}{\partial t}=v C-D_{L} \frac{\partial C}{\partial x}+D_{L}\left(\frac{\partial C}{\partial x}+\frac{\partial^{2} C}{\partial x^{2}} d x\right)-v\left(C+\frac{\partial C}{\partial x} d x\right)-\frac{\partial q}{\partial t}
\end{gathered}
$$

Equation 51 can be reduced to:

$$
\frac{\partial C}{\partial t}=-v \frac{\partial C}{\partial x}+D_{L} \frac{\partial^{2} C}{\partial x^{2}}-\frac{\partial q}{\partial t}
$$

Equation 52 is called the Advection-Reaction-Dispersion equation (previously described). Figure 26 shows the simple schematic of the transport process in the PHREEQC computational code, in which the flow is divided into cells. Each cell consists of solid particles that can interact with the chemicals that may speciate and also can be subjected to processes such as ion-exchange and surface complexation, all together causing changes in chemical concentration. 

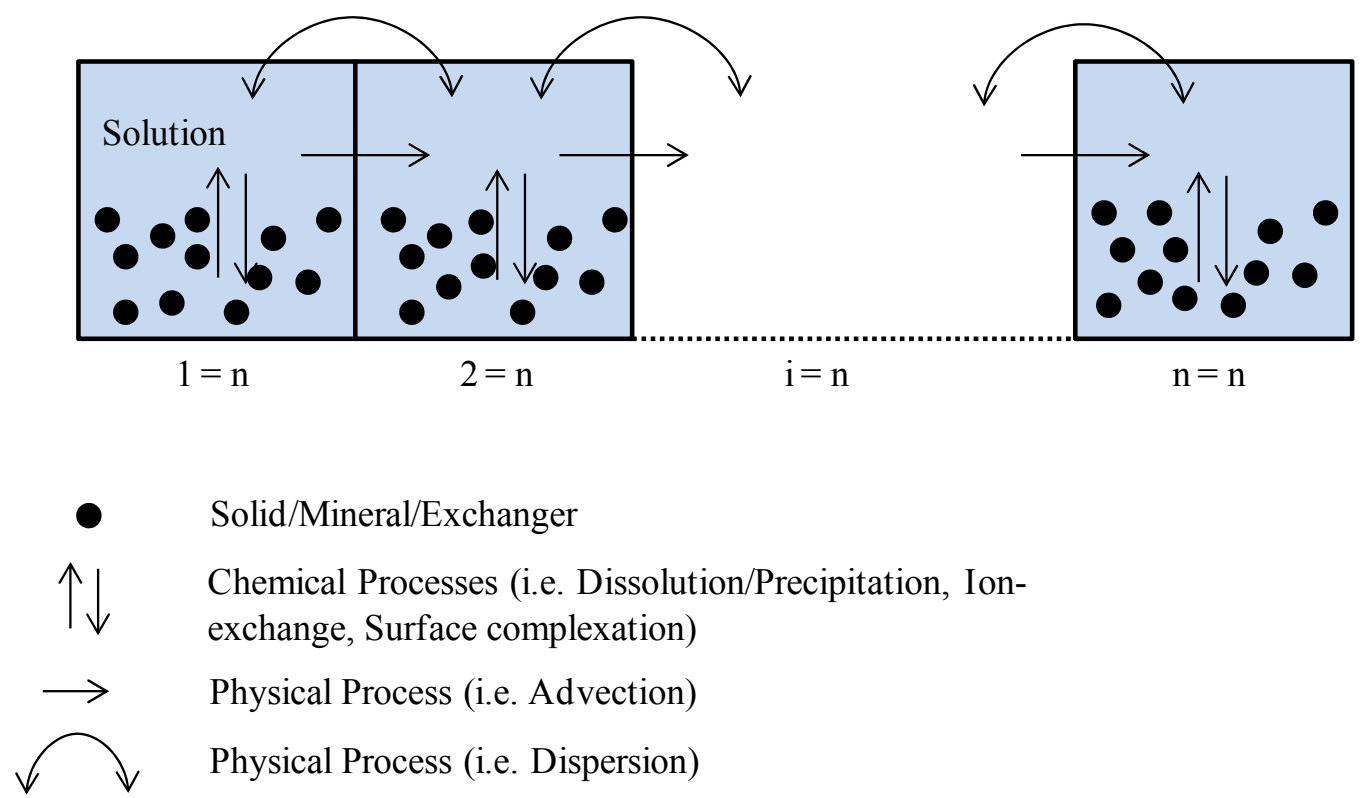

Figure 26 Coupling processes in PHREEQC to transport process calculations This transport process (equation 52), involving advection and dispersion, is solved using finite difference method (using elemental time step $(\Delta \mathrm{t})$ and space $(\Delta \mathrm{x})$, which is the distance between each cell). The chemical change for each element is the sum of all equilibrium and non-equilibrium reactions (solution and dissolution/precipitation, ionexchange, and surface complexation) that are calculated separately from the transport computations for each time step ( $\Delta \mathrm{t})$ (Parkhurst and Appelo 1999).

\subsection{Results and Discussion}

In this section, the enhanced model PHREEQC coupled to transport calculations is used to assess the chemical and physical processes of $\mathrm{Hg}$ in different scenarios. For chemical processes, the simulations are conducted in batch mode. This mode is used to understand the fundamental $\mathrm{Hg}$ behavior at various water $\mathrm{pe}, \mathrm{pH}$, and temperatures, and in the presence of different exchangers and sorbents (section 5.3.1), but in the absence of 
transport. The enhanced model is then further used to perform the simulation of $\mathrm{Hg}$ fate and transport. A sensitivity analysis of chemical (CEC and sorbents) and physical $\left(v, \mathrm{D}_{\mathrm{L}}\right)$ parameters was conducted to study the effect of these parameters on the $\mathrm{Hg}$ fate and transport (section 5.3.2).

\subsubsection{Chemical Processes: Batch Mode}

Simulations of $\mathrm{Hg}$ behavior at different scenarios were carried out using the water quality obtained from groundwater monitoring well 135 located in the ORR area (Table 39). The water quality data in Table 39 is used for all $\mathrm{Hg}$ chemical process simulations (sections 5.3.1.1 to 5.3.1.5).

Table 39 Water quality data obtained from groundwater well 135 located in ORR area (Dreier et al., 1993; Elvado Environmental LLC, 2009 and 2011)

\begin{tabular}{|cccc|}
\hline Parameters & Value & Parameters & Value \\
\hline $\mathbf{p H}$ & $6.0-8.0$ & $\mathbf{S O}_{\mathbf{4}}(\mathbf{m g} / \mathbf{L})$ & $2-6$ \\
\hline Temperature $^{\circ} \mathbf{C}$ & 20.2 & $\mathbf{N O}_{\mathbf{3}}(\mathbf{m g} / \mathbf{L})$ & $0.5-1$ \\
\hline $\mathbf{K}(\mathbf{m g} / \mathbf{L})$ & $0.61-0.88$ & $\mathbf{F e}(\mathbf{m g} / \mathbf{L})$ & $0.1-0.3$ \\
\hline $\mathbf{N a}(\mathbf{m g} / \mathbf{L})$ & $0.37-0.58$ & $\mathbf{H g}(\mathbf{m g} / \mathbf{L})$ & $0.00086-0.0066$ \\
\hline $\mathbf{M g}(\mathbf{m g} / \mathbf{L})$ & $17-22$ & $\mathbf{P b}(\mathbf{m g} / \mathbf{L})$ & $0.004-0.006$ \\
\hline $\mathbf{C a}(\mathbf{m g} / \mathbf{L})$ & $28-33$ & $\mathbf{Z n}(\mathbf{m g} / \mathbf{L})$ & $0.013-0.022$ \\
\hline $\mathbf{C l}(\mathbf{m g} / \mathbf{L})$ & $1-2$ & $\mathbf{C d}(\mathbf{m g} / \mathbf{L})$ & $0.0031-0.059$ \\
\hline
\end{tabular}

\subsubsection{Hg pe-pH diagram}

The objective of this analysis is to assess the Hg-species distribution of various soluble and insoluble forms at various pe-pH values using the enhanced PHREEQC model. The pe-pH diagram shows in a comprehensive way how protons and electrons 
shift equilibrium and which species are present and dominant under any given condition of pe and $\mathrm{pH}$.

In this study, the pe-pH diagrams of $\mathrm{Hg}$-species were developed based on the redox stability of water, which are shown next in equations 53-54.

$$
\begin{aligned}
& 2 \mathrm{H}^{+}+2 e=\mathrm{H}_{2}(\mathrm{~g}) \quad \log \mathrm{K}=0 \\
& \mathrm{O}_{2}(\mathrm{~g})+4 \mathrm{H}^{+}+4 e=2 \mathrm{H}_{2} \mathrm{O} \quad \log \mathrm{K}=83.1
\end{aligned}
$$

The pe-pH values associate with the partial pressure of $\mathrm{H}_{2}$ and $\mathrm{O}_{2}$, as shown in equations $55-56$.

$$
\begin{aligned}
& \log \mathrm{p}_{\mathrm{H}_{2}}=0-2 p H-2 p e \\
& \log \mathrm{p}_{\mathrm{O}_{2}}=-83.1+4 p H-4 p e
\end{aligned}
$$

The above equations can be rewritten as equations $57-58$, where pe is a function of $\mathrm{pH}$.

$$
\begin{aligned}
& \text { pe }=0-p H-\frac{1}{2} \log \mathrm{p}_{\mathrm{H}_{2}} \\
& \text { pe }=20.78-p H+\frac{1}{4} \log \mathrm{p}_{\mathrm{O}_{2}}
\end{aligned}
$$

The diagrams were produced using the enhanced database of the PHREEQC model, which allows modelers to assess the formation of $\mathrm{Hg}$ species; soluble and insoluble forms, at various pe-pH values. In addition to the capabilities of the existing PHREEQC model, the enhanced model is capable of estimating the pe-pH conditions that favor the sorption of $\mathrm{Hg}$ and the mobility of $\mathrm{Hg}$. The water quality in Table 39 was selected for the $\mathrm{Hg}$ pe-pH diagram study. This is because the diverse presence of various chemical constituents in the water allows the possibility of the formation of several Hgspecies for any given pe and $\mathrm{pH}$ conditions. Although the water quality used for the 
diagram study (Table 39) was groundwater quality data, however, the diagram study is not specific only for groundwater condition. The $\mathrm{Hg}$ pe-pH diagram study helps in describing the trend of $\mathrm{Hg}$ behavior in various aquatic environments depending on the given of pe-pH.

The simulations of $\mathrm{Hg}$ pe-pH diagrams were determined based on 3 different scenarios: 1) without sorbent; 2) with $\mathrm{Fe}(\mathrm{OH})_{3}$ sorbent; and 3) $\mathrm{Hg}$ mobility with $\mathrm{Fe}(\mathrm{OH})_{3}$. Scenario 1: pe-pH of Hg without sorbent

Using the water chemical composition in Table 39, the pe-pH diagram of $\mathrm{Hg}$ species at various pe-pH values is shown in Figure 27. The diagram shows the thermodynamically stable species of $\mathrm{Hg}$ at different pe-pH, of which only 2 oxidation states $\left(\mathrm{Hg}^{0}\right.$ and $\left.\mathrm{Hg}^{2+}\right)$ and one solid phase (cinnabar) are stable.

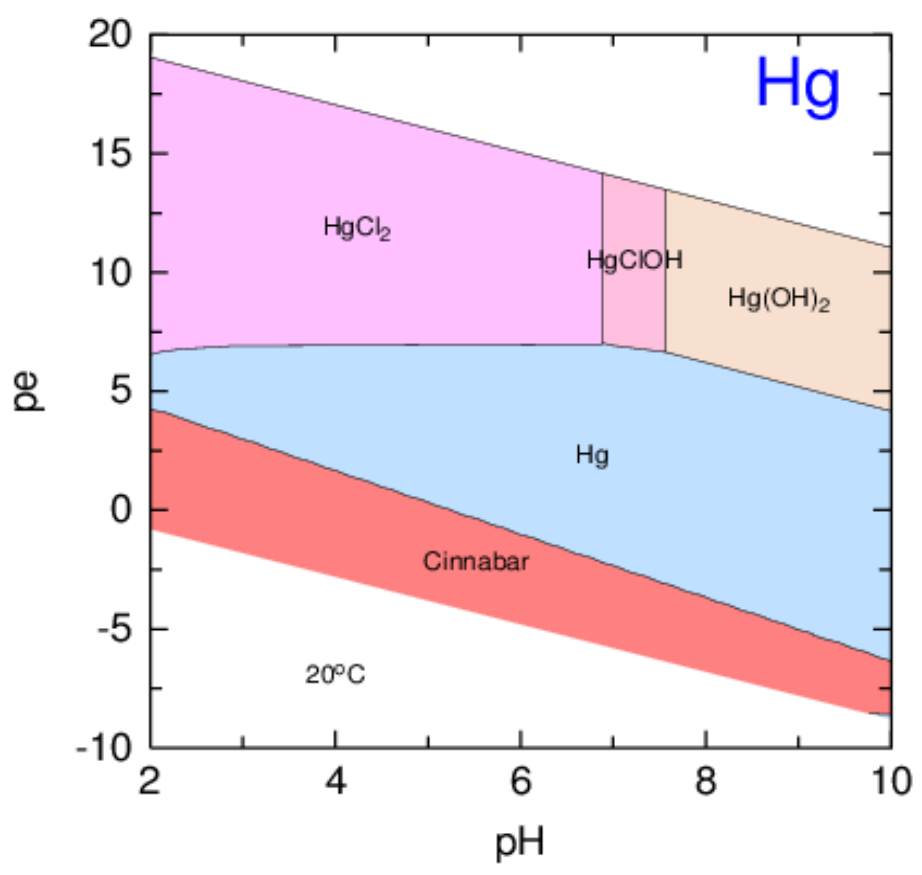

Figure $27 \mathrm{pe}-\mathrm{pH}$ diagram of $\mathrm{Hg}$-species at temperature $20{ }^{\circ} \mathrm{C}$

In oxidation condition of water, $\mathrm{Hg}^{2+}$ complexes with inorganic ions: $\mathrm{Cl}$ ion at $\mathrm{pH}$ $<7, \mathrm{Cl}-\mathrm{OH}$ ion at $\mathrm{pH} \sim 7-7.5$ and $\mathrm{OH}$ ion at $\mathrm{pH}>7.5$. The reaction between $\mathrm{SO}_{4}$ ion and 
$\mathrm{Hg}$ is negligible in oxidizing water condition. However, in reducing water condition where $\mathrm{S}^{6+}$ is reduced to $\mathrm{S}^{2+}$, the solid phase of $\mathrm{HgS}$ (cinnabar) is formed. This is because $\mathrm{Hg}$ has high affinity for sulfide. For such reducing water conditions, cinnabar is present at all $\mathrm{pH}$ of water. The result obtained from the model is consistent with various studies (Little, 2006; Chattopadhyay and Ickes, 2001; Davis et al., 1997; Cox et al. 1996; Sigels, 1997) that had developed the pe-pH diagrams of $\mathrm{Hg}$ using both geochemical models and analytical calculation. The results from some previous studies on $\mathrm{Hg}$ pe-pH diagram are summarized here (Figures 28-31). The result obtained using the PRHEEQC model is consistent with those from previous studies. It was confirmed that only two oxidation states $\left(\mathrm{Hg}^{0}\right.$ and $\left.\mathrm{Hg}^{2+}\right)$ and one solid phase (HgS or cinnabar) are thermodynamically stable in the pe-pH ranges considered here ( $\mathrm{pe}=-10$ to $20, \mathrm{pH}=2$ to 10 ).

Sigel, A. and Sigel, H., 1997, Little, 2006 and Davis et al., 1997 developed pe-pH diagram of $\mathrm{Hg}$ using water conditions that consist of $\mathrm{Cl}, \mathrm{SO}_{4}$ and $\mathrm{Hg}$. According to their studies, $\mathrm{HgCl}_{2}$ is the dominant species at $\mathrm{pH}<7$ while $\mathrm{Hg}(\mathrm{OH})_{2}$ is present at $\mathrm{pH}>7$ (Figures 28-30). Cox et al., 1996 developed the pe-pH diagram (Figure 31) using the water condition that consists of $\mathrm{I}, \mathrm{SO}_{4}$ and $\mathrm{Hg}$. In this case, $\mathrm{HgI}_{2}$ and $\mathrm{Hg}_{2} \mathrm{I}_{2}$ were observed under oxidizing conditions. The complexation of $\mathrm{HgSO}_{4}$ was not obtained in oxidizing water. This can be attributed to its low thermodynamic constant $\left(\log \mathrm{K}=2.6\right.$ for $\mathrm{HgSO}_{4}$, 14.2 for $\mathrm{HgCl}_{2}$ and 24.8 for $\mathrm{HgI}_{2}$ (Powell, et al., 2005; Martell and Smith 2001)). However, in reducing condition, $\mathrm{Hg}$ readily complexed with $\mathrm{S}$ (as sulfide) resulting in $\mathrm{HgS}$ (cinnabar), which is the dominant species in such water condition. This species was observed in all the previous studies. 


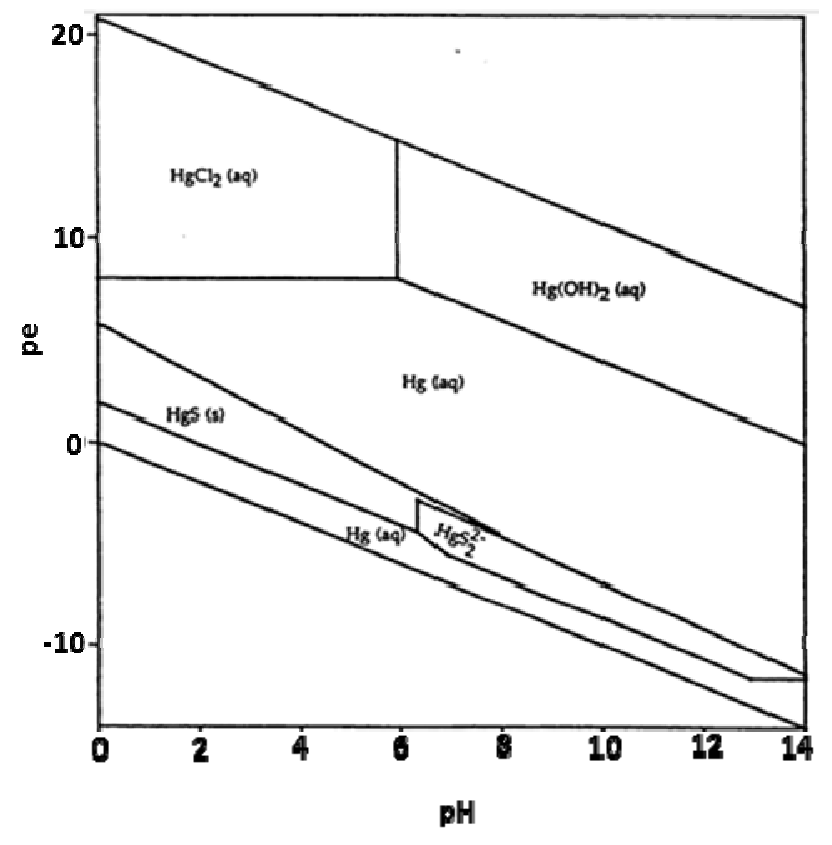

Figure 28 A pe-pH diagram for mercury in a typical soil solution (total $\mathrm{Hg}$ of $5 \times 10^{-11} \mathrm{M}$, $\mathrm{Cl}$ of $2 \times 10^{-4} \mathrm{M}$ and S of $6 \times 10^{-4} \mathrm{M}$ ) (Sigel, A. and Sigel, H., 1997)

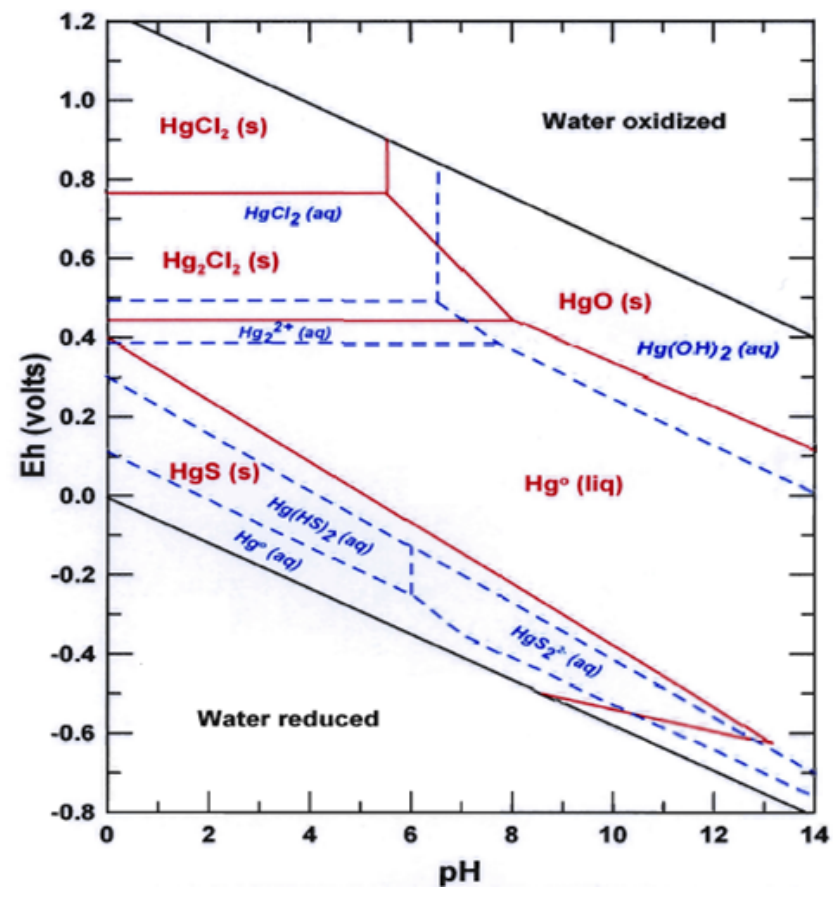

Figure 29 Eh-pH diagram for $\mathrm{Hg}$ at $25^{\circ} \mathrm{C}$ and 1 atmosphere pressure. The dashed lines represent the stability field of aqueous species, and solid lines are for solid phases. System includes water containing $36 \mathrm{mg} / \mathrm{L} \mathrm{Cl}$, total S $96 \mathrm{mg} / \mathrm{L}$ as $\mathrm{SO}_{4}{ }^{2-}$ (Little, M.E., 2006). On axis y, pe ranges from -13.5 to 20 (Eh to pe conversion is calculated using Ehpe relationship: Eh $(\mathrm{mV})=59.2 \mathrm{pe}$, obtained from Stumm and Morgan, 1996) 


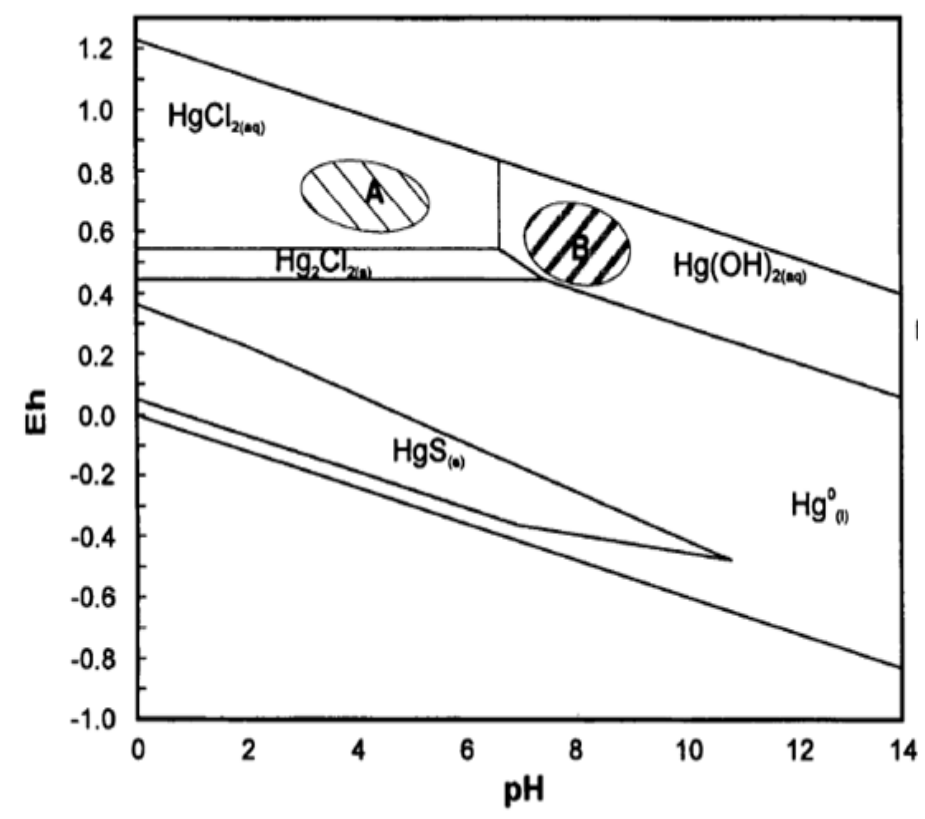

Figure 30 Davis et al., 1997 studied the ability of mercury to cross tissue membranes of the mouth, esophagus, stomach, and the small and large intestines. Figure shows Gastrointestinal tract $\mathrm{pH}$-Eh conditions superimposed on mercury system, $\mathrm{A}=$ Stomach, and $\mathrm{B}=$ Small Intestinal conditions. Activity of $\mathrm{Cl}=10^{-3} \mathrm{M}, \mathrm{S}=10^{-5} \mathrm{M}, \mathrm{Hg}=10^{-5} \mathrm{M}$. On axis y, pe ranges from -16 to 20 (Eh-pe conversion is calculated using Eh-pe relationship: Eh $(\mathrm{mV})=59.2 \mathrm{pe}$, obtained from Stumm and Morgan, 1996)

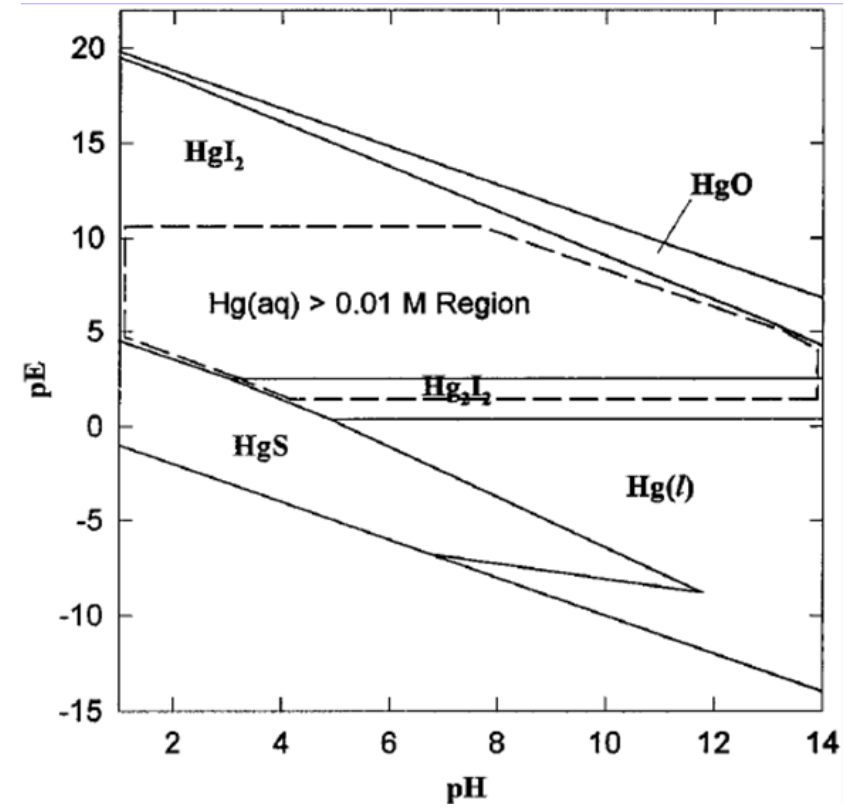

Figure 31 Stability diagram for $\mathrm{Hg}$ in the presence of $0.1 \mathrm{M}$ total I and $0.001 \mathrm{M}$ of S (Cox et al., 1996) 
The result obtained from PHREEQC model (Figure 27) are comparable with the results obtained from previous studies (Figures 28-31). The difference is that the $\mathrm{Hg}$ database of PHEEQC model was enhanced by adding the thermodynamic data of $\mathrm{HgClOH}$ species. Thus in Figure 27, $\mathrm{HgClOH}$ is dominant approximately in the $\mathrm{pH}$ range of 7-7.5, in oxidizing water condition. It is to be noted here that the range of $\mathrm{x}$ and $\mathrm{y}$ axes in Figure 27 is a subset of the corresponding axes displayed in Figures 28-31. This made the comparison between the figures possible.

Scenario 2: pe-pH of $\mathrm{Hg}$ with $\mathrm{Fe}(\mathrm{OH})_{3}$ sorbent

In this simulation, the enhanced model was used to assess the pe-pH values that favor the surface complexation between $\mathrm{Hg}$ and $\mathrm{Fe}(\mathrm{OH})_{3}$ sorbent. It was assumed that the Fe concentration in solution was $20 \mathrm{mg} / \mathrm{L}$ ( or $\log \mathrm{Fe}_{\mathrm{T}}=-3.4 \mathrm{~mole}$ ). The water quality data employed in this simulation is shown in Table 39. The $\mathrm{Fe}(\mathrm{OH})_{3}$ surface properties and the surface sorption constants for $\mathrm{Hg}$ of Tables 10 and 11 were used in all model calculations. The precipitation of $\mathrm{Fe}(\mathrm{OH})_{3}$ and the $\mathrm{Hg}$ sorption on the precipitated $\mathrm{Fe}(\mathrm{OH})_{3}$ were simulated for different pe-pH conditions. The results are shown in Figure 32. 


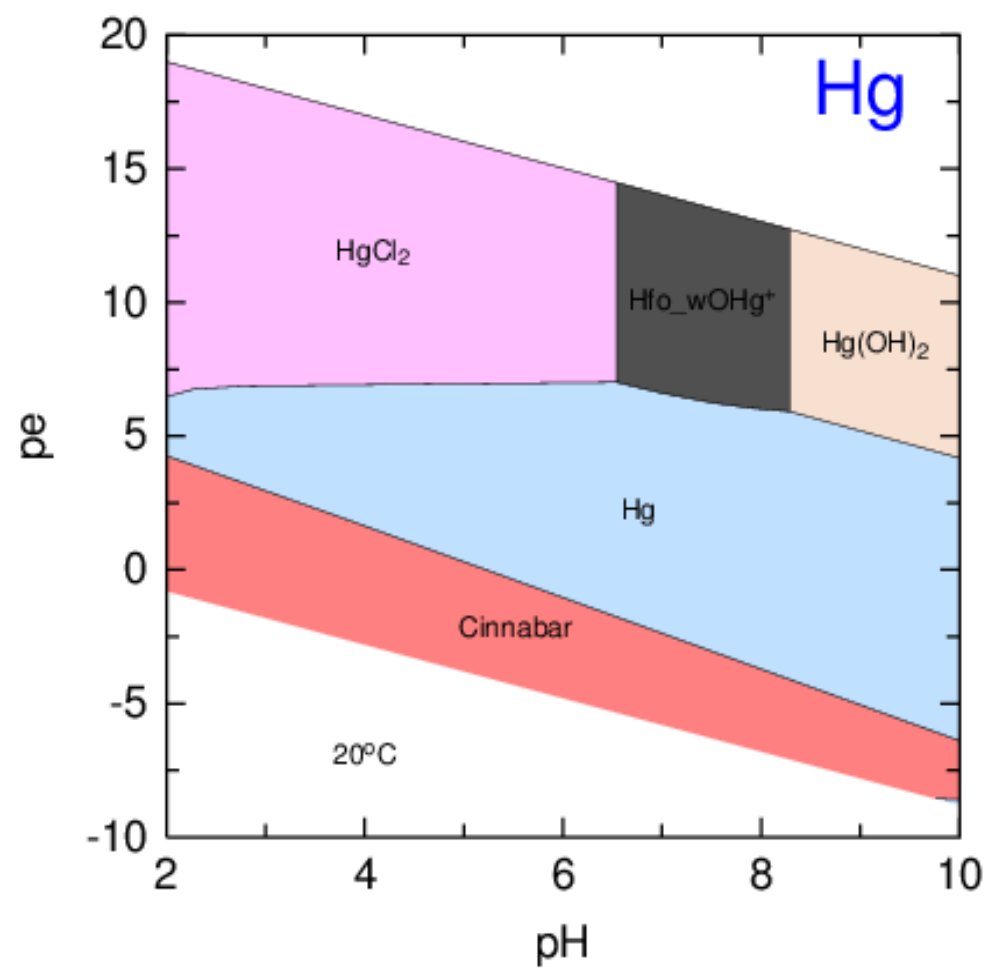

Figure $32 \mathrm{pe}-\mathrm{pH}$ diagram of $\mathrm{Hg}$-species with $\mathrm{Fe}=20 \mathrm{mg} / \mathrm{L}$ and at temperature $20^{\circ} \mathrm{C}$

Figure 32 shows that, in oxidizing water condition, the precipitation of $\mathrm{Fe}(\mathrm{OH})_{3}$ mineral occurred at $\mathrm{pH}$ 7-8. $\mathrm{Hg}$ simultaneously sorbed onto precipitated $\mathrm{Fe}(\mathrm{OH})_{3}$ surface by forming surface complexes at these $\mathrm{pH}$ ranges. It can also be observed that $\mathrm{Hg}$ sorbed on the weak sorption sites of $\mathrm{Fe}(\mathrm{OH})_{3}\left(\mathrm{Hfo}_{-} \mathrm{wOHg}^{+}\right)$. This is due to the abundance of $\mathrm{Fe}(\mathrm{OH})_{3}$ weak sorption sites (weak sites $=0.2 \mathrm{~mol} / \mathrm{molFe}$, strong sites $=0.005$ $\mathrm{mol} / \mathrm{molFe}$ ) (Dzombak and Morel, 1990). It can be concluded that, at $\mathrm{pH} 7-8, \mathrm{Fe}(\mathrm{OH})_{3}$ dominates $\mathrm{Cl}^{-} \mathrm{OH}$ ligand for $\mathrm{Hg}$ complexation.

Scenario 3: pe-pH of Hg mobility

Using the water quality conditions in scenario 2, the $\mathrm{Hg}$ phases (dissolved and solid phases) in Figure 32 also present the possibility of $\mathrm{Hg}$ to be mobilized in the water. 
In order to better describe the potential for mobilization, Figure 32 is redrawn into a $\mathrm{Hg}$ mobilization diagram that is shown in Figure 33.

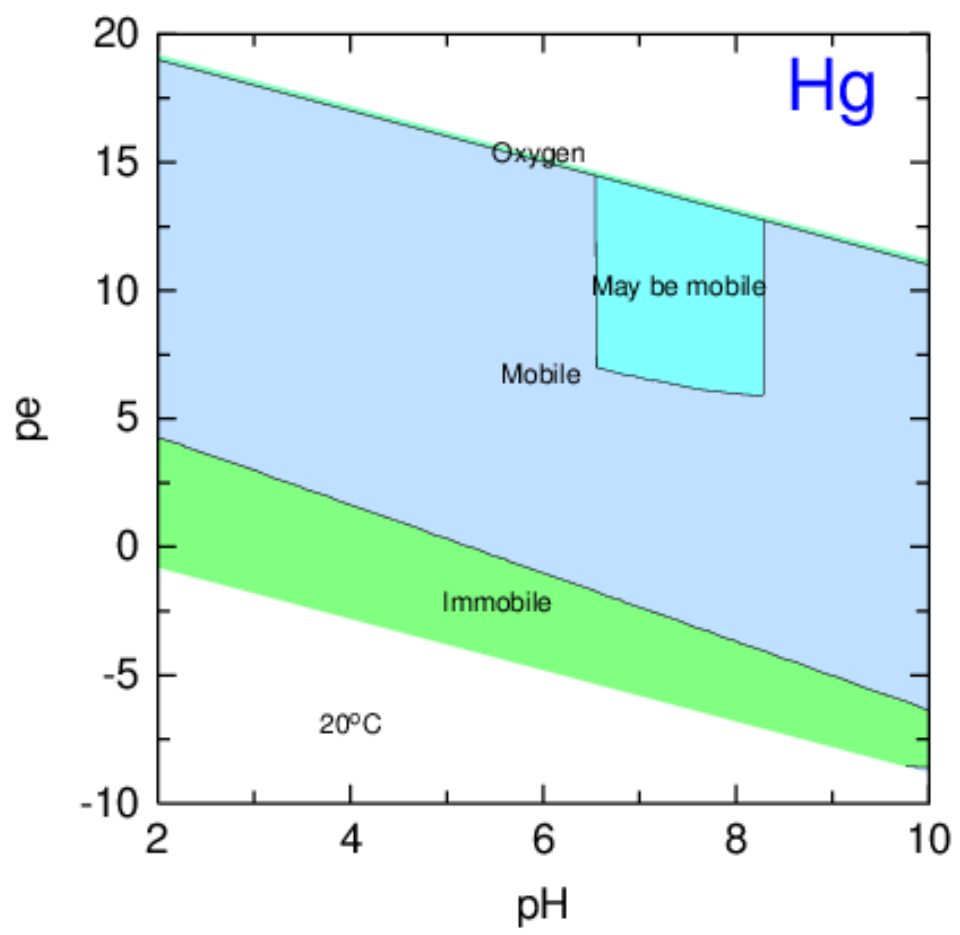

Figure 33 pe-pH diagram of $\mathrm{Hg}$ mobilization with $\mathrm{Fe}=20 \mathrm{mg} / \mathrm{L}$, temperature $20^{\circ} \mathrm{C}$

The "mobile" section in the figure suggests that the dissolved $\mathrm{Hg}$ will be transported in the water while "immobile" indicates that cinnabar (i.e., solid phase) is immobilized. Of course, if the precipitated $\mathrm{Fe}(\mathrm{OH})_{3}$ is present as fine particles then the sorbed $\mathrm{Hg}$ may be transported with water. Otherwise, it may settle down. Similarly, a "may be mobile" section is also depicted for pe-pH ranges, where $\mathrm{Hg}$ sorption occurs.

\subsubsection{Sensitivity analysis of $\mathrm{Hg}$ species to water $\mathrm{pH}$ and temperature}

A sensitivity analysis was conducted using the water quality data in Table 39 . The temperature was varied from $5-35{ }^{\circ} \mathrm{C}$ and water $\mathrm{pH}$ within $2-10$. The results of the simulations analysis are shown in Figure 34. 

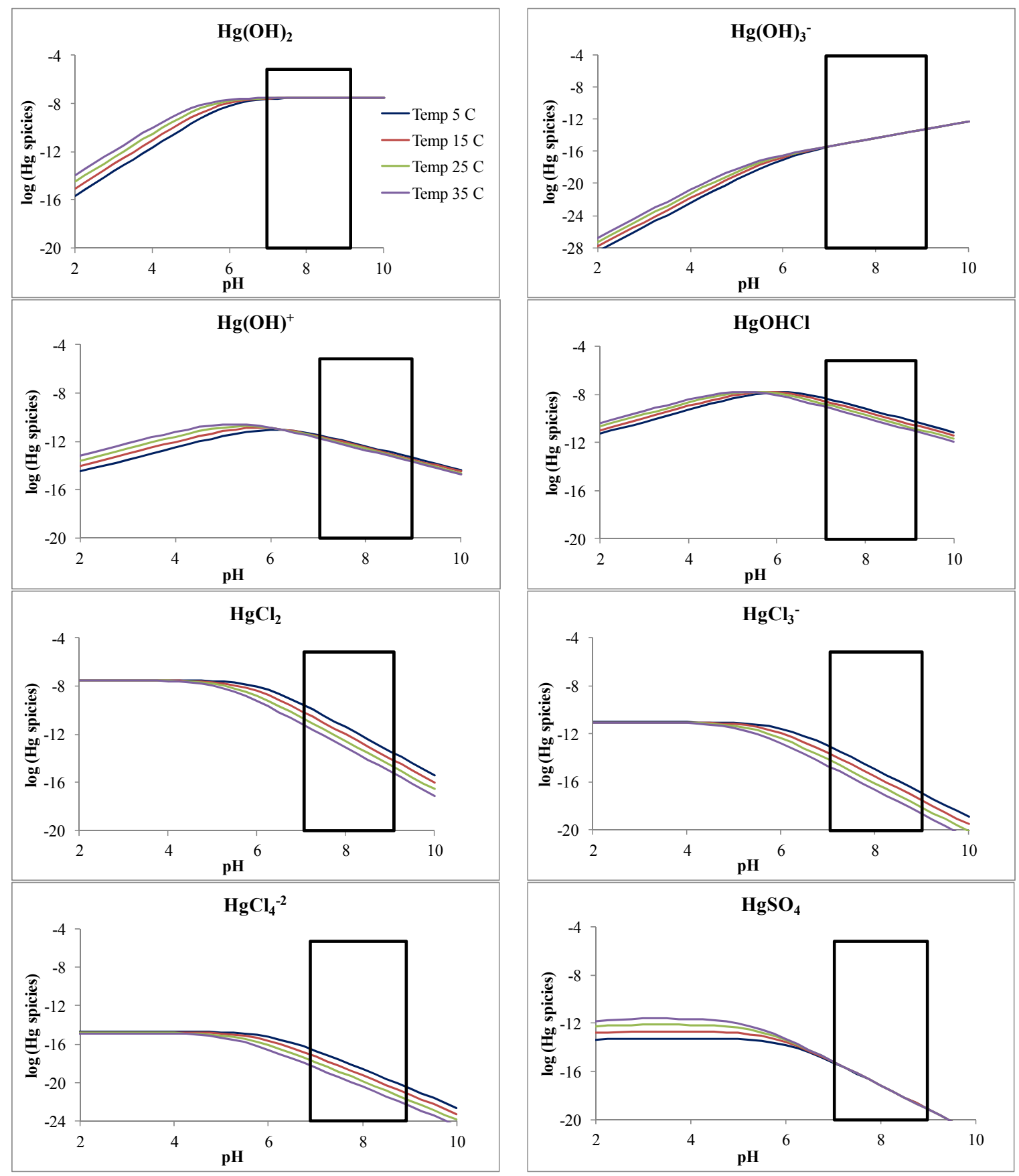

Figure $34 \mathrm{Hg}$ species sensitivity to temperature $\left(5-35^{\circ} \mathrm{C}\right)$ and $\mathrm{pH}(2-10)$, black box shows groundwater $\mathrm{pH}$ range 
It can be observed in Figure 34 that the formation of $\mathrm{Hg}-\mathrm{OH}$ species increases with increase in water temperature, while the temperature does not favor the formation of $\mathrm{Hg}-\mathrm{Cl}$ species. Temperature favors the formation of $\mathrm{HgSO}_{4}$ at $\mathrm{pH} 2-6$. The effect of temperature is negligible for $\mathrm{pH}>6$. Increase in water $\mathrm{pH}$ also increases the formation of $\mathrm{Hg}(\mathrm{OH})_{2}$ and $\mathrm{Hg}(\mathrm{OH})_{3}{ }^{-}$.However for $\mathrm{Hg}(\mathrm{OH})^{+}$and $\mathrm{HgOHCl}$, the concentrations increase with water $\mathrm{pH}$ between 2-7; for $\mathrm{pH}>7$, their concentrations were observed to decline. Low water $\mathrm{pH}(\mathrm{pH} 2-6)$ does not appear to have any influence on $\mathrm{Hg}-\mathrm{Cl}$ concentrations, but, $\mathrm{Hg}-\mathrm{Cl}$ concentration decreases at $\mathrm{pH}>6$.

5.3.1.3 Sensitivity analysis of mineral saturation index with respect to water $\mathrm{pH}$ and temperature

The sensitivity analysis using the water quality data in Table 39 was conducted for a range of water temperature $\left(5-35^{\circ} \mathrm{C}\right)$ and $\mathrm{pH}(2-10)$.

Figure 35 shows the effect of water temperature and $\mathrm{pH}$ on the SI of dominant minerals for the water condition in Table 39. From the figure, it can be seen that the SI of Ferrihydrite, Goethite, Magnesioferrite, Hematite, K-Jarosite, and Na-Jarosite increase with water temperature, while temperature does not affect the formation of $\mathrm{Fe}(\mathrm{OH})_{2.7} \mathrm{Cl}_{3}$ and Lepidocrocite. Increase in water $\mathrm{pH}$ favors the formation of all the above minerals, except for K-Jarosite and Na-Jarosite, whose SIs decrease at $\mathrm{pH}$ greater than 8. This analysis also indicates that at $\mathrm{pH} 7-9.2$; temperature $25^{\circ} \mathrm{C}$, water is supersaturated with Ferrihydrite, Goethite, Magnesioferrite, Hematite, K-Jarosite, Na-Jarosite, $\mathrm{Fe}(\mathrm{OH})_{2.7} \mathrm{Cl}_{3}$, and Lepidocrocite. 

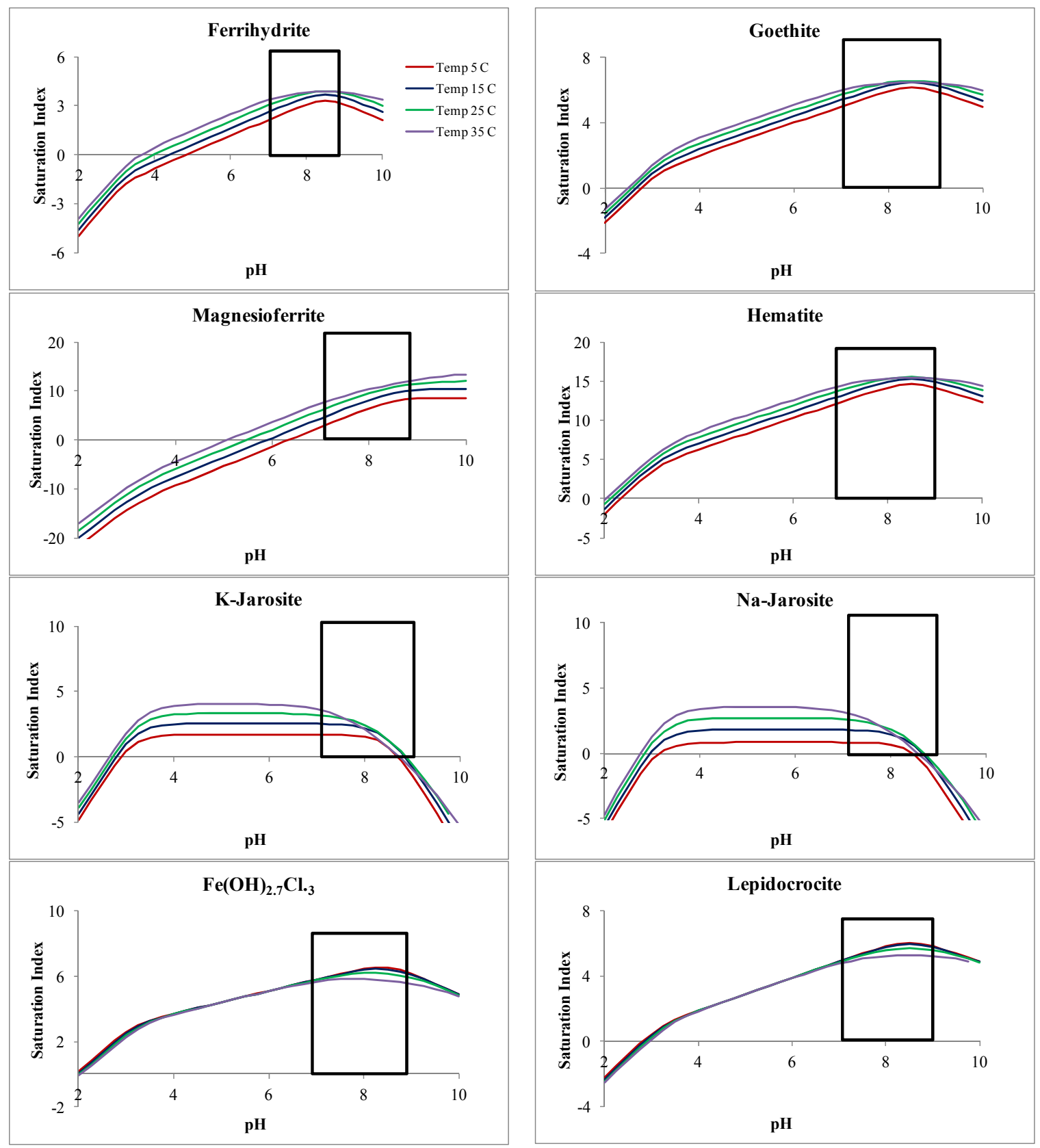

Figure 35 Sensitivity of the SI of minerals to water temperature and $\mathrm{pH}$ at oxidation water condition 
5.3.1.4 Sensitivity analysis of $\mathrm{Hg}$-species with respect to the exchangers (Illite, Montmorillonite, Vermiculite)

The effect of exchangers on Hg-species concentrations was investigated at a water temperature of $25^{\circ} \mathrm{C}$ and $\mathrm{pH} 2-10$ (Figure 36).
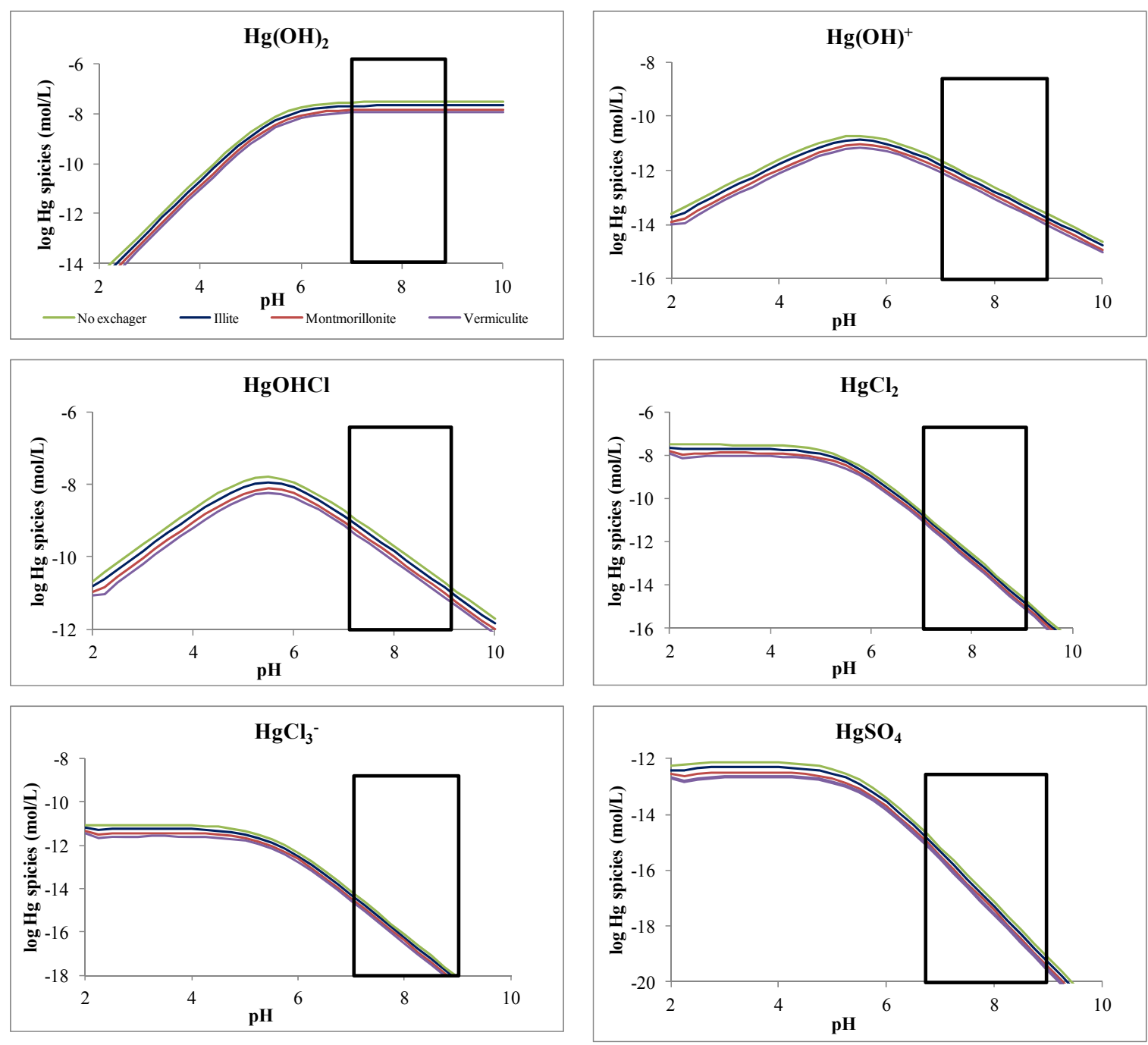

Figure 36 Sensitivity analysis of $\mathrm{Hg}$-species concentration with respect to different exchangers (the effect of ion exchange); $1 \mathrm{~kg} / \mathrm{L}$ of exchangers, temperature $25^{\circ} \mathrm{C}$, oxidation condition 
It should be noted that only the effect of ion exchange (no surface complexation) is considered here. The ion exchange simulations were conducted using $1 \mathrm{~kg}$ of exchangers with different CEC: Illite (CEC $6.5 \mathrm{~mol} / \mathrm{L}$ ), Montmorillonite (CEC 15 $\mathrm{mol} / \mathrm{L}$ ), Vermiculite (CEC $26 \mathrm{~mol} / \mathrm{L}$ ). Figure 36 shows that the exchange of $\mathrm{Hg}$ increases with CEC in the following order; Illite $<$ Montmorillonite $<$ Vermiculite.

It can also be observed in Figure 36 that the exchange reactions of $\mathrm{Hg}(\mathrm{HO})_{2}$ and $\mathrm{Hg}(\mathrm{OH})^{+}$species occur at high $\mathrm{pH}$. However, high $\mathrm{pH}$ does not favor the exchange reaction of $\mathrm{HgCl}_{2}, \mathrm{HgCl}_{3}{ }^{-}$, and $\mathrm{HgSO}_{4}$ species. Low $\mathrm{pH}$ favors formation of $\mathrm{HgCl}_{2}$, $\mathrm{HgCl}_{3}{ }^{-}$, and $\mathrm{HgSO}_{4}$, thus, the better exchange reaction of these species are obtained.

$$
\begin{aligned}
& \text { 5.3.1.5 Sensitivity analysis of } \mathrm{Hg} \text {-species concentration with respect to } \\
& \text { sorbents: }\left(\mathrm{Fe}(\mathrm{OH})_{3}\right. \text {, Gibbsite, Kaolinite) }
\end{aligned}
$$

The effect of sorbents on $\mathrm{Hg}$-species concentration was carried out at water temperature of $25{ }^{\circ} \mathrm{C}, \mathrm{pH} 2-10$. It should be noted that only the effect of surface complexation is considered here (no ion exchange). The simulations were conducted using $1 \mathrm{~g} / \mathrm{L}$ of $\mathrm{Fe}(\mathrm{OH})_{3}$, Gibbsite, and Kaolinite.

It can be observed in Figure 37 that at $\mathrm{pH} 2-4$ surface complexation does not occur. This is because at low $\mathrm{pH}$ the surface complexation of $\mathrm{H}^{+}$is dominant at high values $\log \mathrm{K}$ of $7.29,4.7$, and 3.7 for $\mathrm{Fe}(\mathrm{OH})_{3}$, Gibbsite and Kaolinite, respectively. These $\log \mathrm{K}$ values are very high compared to those for surface complexation of $\mathrm{HgCl}_{2}$, which is the dominant species at low $\mathrm{pH}$. Therefore, it could be said that, at low $\mathrm{pH}$, there is no available surface for $\mathrm{Hg}$ complexation. $\mathrm{Fe}(\mathrm{OH})_{3}$ shows high surface complexation with all $\mathrm{Hg}$-species at $\mathrm{pH} 4.5-8.5$ compared to other sorbents. This is because of the high surface complexation constant $(\log \mathrm{K})$. However, the complexation cannot take place at 
$\mathrm{pH}>$ 8.5. This is due to the Point of Zero Charge (PZC) of $\mathrm{Fe}(\mathrm{OH})_{3}$, which ranges between $\mathrm{pH} 8.5$ - 9.3. Therefore, the surface complexation does not occur at this $\mathrm{pH}$ range. With Kaolinite and Gibbsite, the $\mathrm{Hg}$ surface complexation is obtained at $\mathrm{pH}>5$.
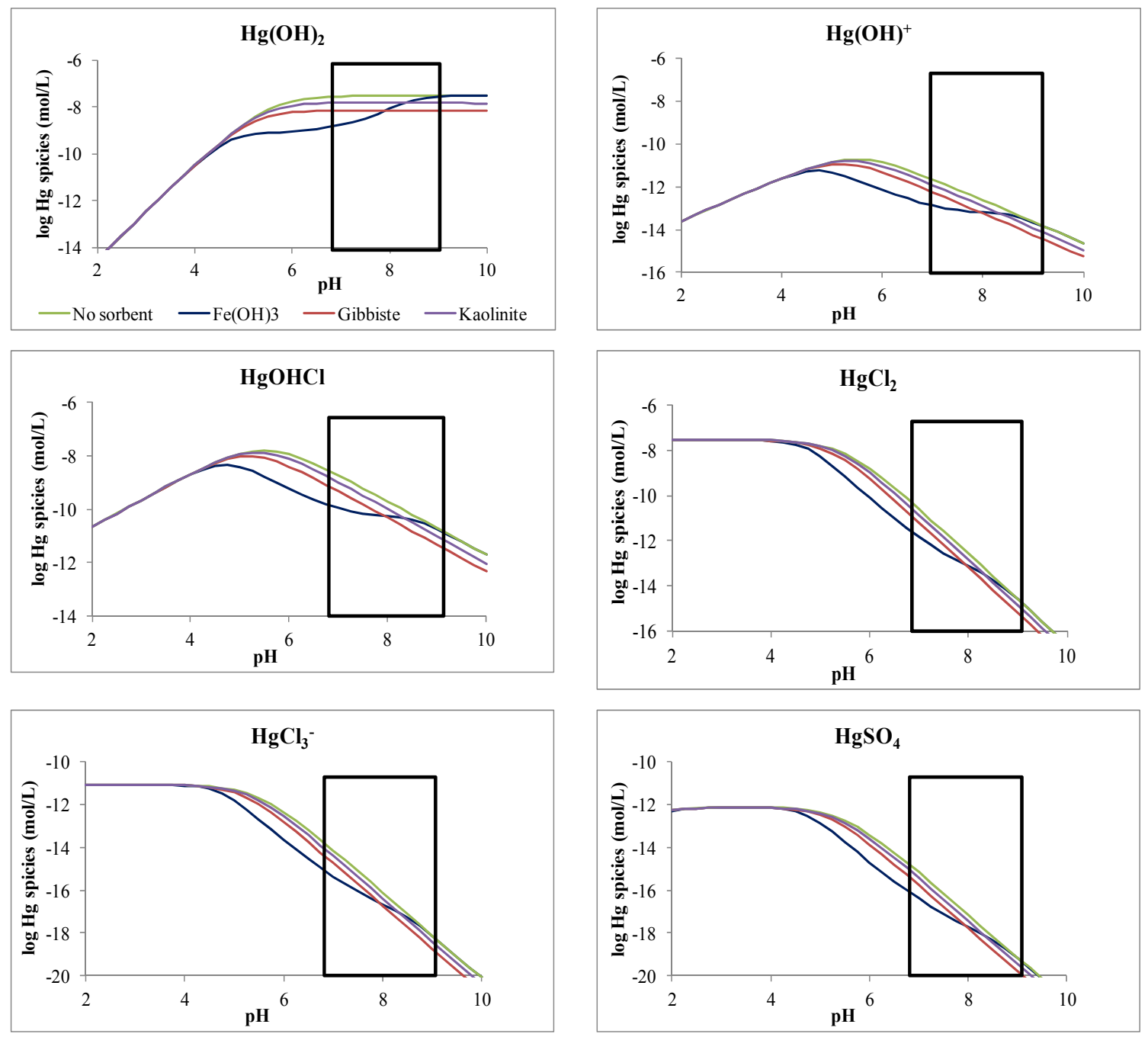

Figure 37 Sensitivity analysis of $\mathrm{Hg}$-species concentration with respect to different sorbents (the effect of surface complexation) $; 1 \mathrm{~g} / \mathrm{L}$ of sorbents, temperature $25^{\circ} \mathrm{C}$, oxidation condition 
It can also be seen that $\mathrm{Hg}(\mathrm{OH})_{2}, \mathrm{Hg}(\mathrm{OH})^{+}$and $\mathrm{HgClOH}$ can complex with all sorbents better than $\mathrm{HgCl}_{2}, \mathrm{HgCl}_{3}{ }^{-}$and $\mathrm{HgSO}_{4}$ species at $\mathrm{pH}$ 4.5-8.5. High formation of $\mathrm{Hg}(\mathrm{OH})_{2}, \mathrm{Hg}(\mathrm{OH})$, and $\mathrm{HgClOH}$ species occurs at this $\mathrm{pH}$ range, while the formation of $\mathrm{HgCl}_{2}, \mathrm{HgCl}_{3}^{-}$and $\mathrm{HgSO}_{4}$ species decreases. Increase in $\mathrm{Hg}(\mathrm{OH})_{2}, \mathrm{Hg}(\mathrm{OH})^{+}$, and $\mathrm{HgClOH}$ formation makes surface complexation reactions possible, which results in a higher surface complexation of these species. The surface complexation of $\mathrm{Hg}$ are in the following order: Kaolinite $<$ Gibbsite $<\mathrm{Fe}(\mathrm{OH})_{3}$. This result is consistent with previous studies (Sarkar et al., 1999 and 2000; Kim et al., 2004; Weerasooriya et al., 2007).

\subsubsection{Chemical and Physical Processes: Transport Mode}

This section describes the utilization of the enhanced model to predict the fate and transport of Hg. Different scenarios were conducted to mimic the typical transport condition in aqueous environments. For all scenario simulations, it was assumed that the background water in the flow reach, with a length of $100 \mathrm{~m}$, is the $\mathrm{Ca}-\mathrm{Mg}-\mathrm{HCO}_{3}$ type, which is a typical background water type that can be found at ORR and South Florida areas. At the beginning of the flow reach, the groundwater (GW-135) consists of all elements, including $\mathrm{Hg}$, as shown in Table 40 , which is the water quality data used in section 5.3.1. Different scenarios were considered to study the effect of chemical processes (i.e. exchangers, sorbents) and physical processes (i.e., $v, \mathrm{D}_{\mathrm{L}}$ ) on $\mathrm{Hg}$ fate and transport. 
Table 40 Water quality data used for $\mathrm{Hg}$ fate and transport simulations (Dreier et al., 1993; Elvado Environmental LLC, 2009 and 2011)

\begin{tabular}{|c|c|c|}
\hline Parameters & Background water & GW-135 \\
\hline $\mathrm{pH}$ & 8.5 & 6.0 \\
\hline Temperature, ${ }^{\circ} \mathrm{C}$ & 20 & 20.2 \\
\hline $\mathrm{K}(\mathrm{mg} / \mathrm{L})$ & - & 0.88 \\
\hline $\mathrm{Na}(\mathrm{mg} / \mathrm{L})$ & - & 0.58 \\
\hline $\mathrm{Mg}(\mathrm{mg} / \mathrm{L})$ & 24 & 22 \\
\hline $\mathrm{Ca}(\mathrm{mg} / \mathrm{L})$ & 40 & 33 \\
\hline $\mathrm{CO}_{3}(\mathrm{mg} / \mathrm{L})$ & 60 & - \\
\hline $\mathrm{Cl}(\mathrm{mg} / \mathrm{L})$ & - & 2 \\
\hline $\mathrm{SO}_{4}(\mathrm{mg} / \mathrm{L})$ & - & 6 \\
\hline $\mathrm{NO}_{3}(\mathrm{mg} / \mathrm{L})$ & - & 1 \\
\hline $\mathrm{Fe}(\mathrm{mg} / \mathrm{L})$ & - & 0.3 \\
\hline $\mathrm{Hg}(\mathrm{mg} / \mathrm{L})$ & - & 0.0066 \\
\hline $\mathrm{Pb}(\mathrm{mg} / \mathrm{L})$ & - & 0.006 \\
\hline $\mathrm{Zn}(\mathrm{mg} / \mathrm{L})$ & - & 0.022 \\
\hline $\mathrm{Cd}(\mathrm{mg} / \mathrm{L})$ & - & 0.059 \\
\hline
\end{tabular}

\subsubsection{Typical groundwater flow}

This section describes the modeling performed on the $\mathrm{Hg}$ fate and transport in a typical groundwater environment. The typical groundwater flow parameters reported in the literature and used in this study are listed in Table 41. 
Table 41 Typical groundwater flow parameters

\begin{tabular}{|c|c|c|c|}
\hline Parameters & ORR area & South Florida area & $\begin{array}{c}\text { Value } \\
\text { used in } \\
\text { this studv }\end{array}$ \\
\hline$v(\mathrm{~m} / \mathrm{d})$ & 0.6-1.0 (Jago et al., 1995) & $\begin{array}{l}\text { 0.51-4.7 for Miami-Dade County } \\
\text { (Krupa et al., 2001) } \\
0.009-0.03 \text { ENP area (Harvey et al., } \\
2002 \text { ) } \\
0.12-0.90 \text { Kissimmee Groundwater } \\
\text { (Campbell et al., 1995) }\end{array}$ & 0.8 \\
\hline$\alpha_{L}(m)$ & 1-2 (Kelkar et al., 2006) & 0.9-12 (Schulze-Makuch, 2005) & 1 \\
\hline $\mathrm{D}_{\mathrm{L}}\left(\mathrm{m}^{2} / \mathrm{d}\right)$ & $\begin{array}{c}0.6-1.2 \text { (calculated using } \\
\left.\mathrm{D}_{\mathrm{L}=} \alpha_{\mathrm{L}} v+\mathrm{D}^{*}\right)\end{array}$ & $\begin{array}{l}8 \times 10^{-3}-56.4 \text { (calculated using } \mathrm{D}_{\mathrm{L}=} \alpha_{\mathrm{L}} v \\
\left.+\mathrm{D}^{*}\right)\end{array}$ & 0.8 \\
\hline$D^{*}\left(\mathrm{~m}^{2} / \mathrm{d}\right)$ & $3 \times 10^{-9}$ (Kelkar et al., 2006) & $3 \times 10^{-9}$ (Harvey et al., 2002) & $3 \times 10^{-9}$ \\
\hline
\end{tabular}

The Hg fate and transport in a typical groundwater enviroment were investigated for 3 different scenarios: 1) without exchangers and sorbents; 2) with exchangers; and 3) with sorbents.

Scenario 1: Without exchangers and sorbents

Figure 38 shows the simple schematic of this transport scenario, where the flow reach of $100 \mathrm{~m}$ long is divided into 10 cells for the coupled PHREEQC model's calculation. The water quality data in Table 40 and flow parameters in Table 41 were used in the simulations. 

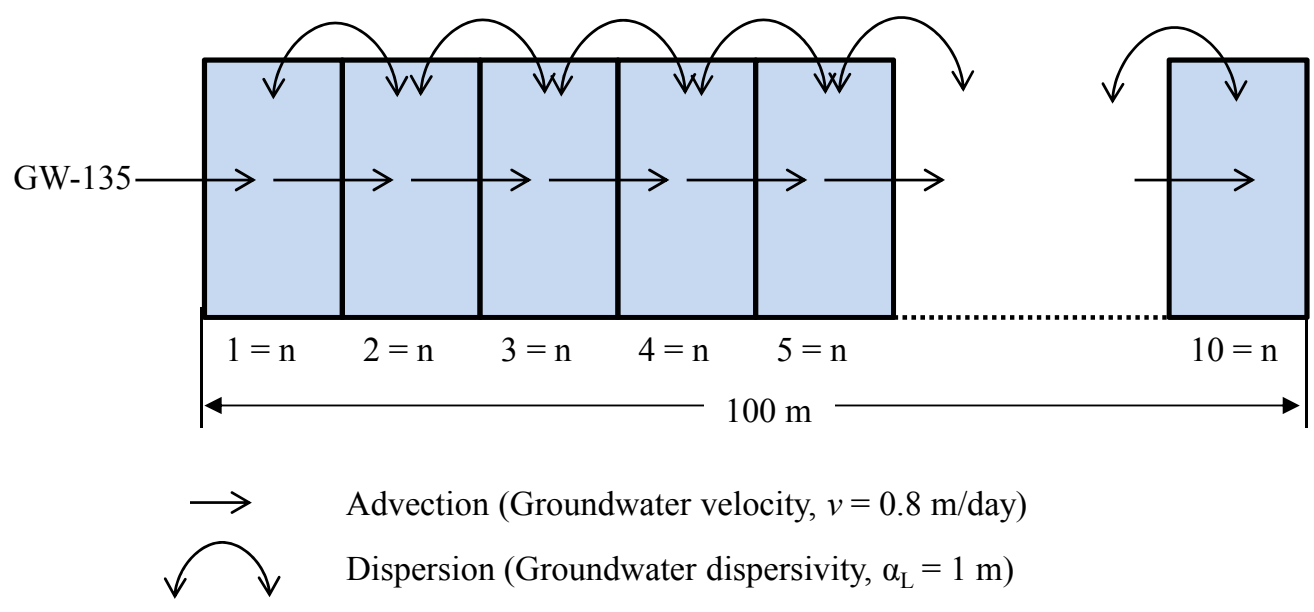

Background water solution

Figure 38 Model of $\mathrm{Hg}$ transport for a typical groundwater flow condition

The GW-135 flows through the reach with $\mathrm{Ca}-\mathrm{Mg}-\mathrm{CO}_{3}$ water type, with no interactions between $\mathrm{Hg}$ and the solid (exchanger/sorbent). PHREEQC calculated the Hg-species profile based on inputted water quality data and flow parameters (Figure 39).

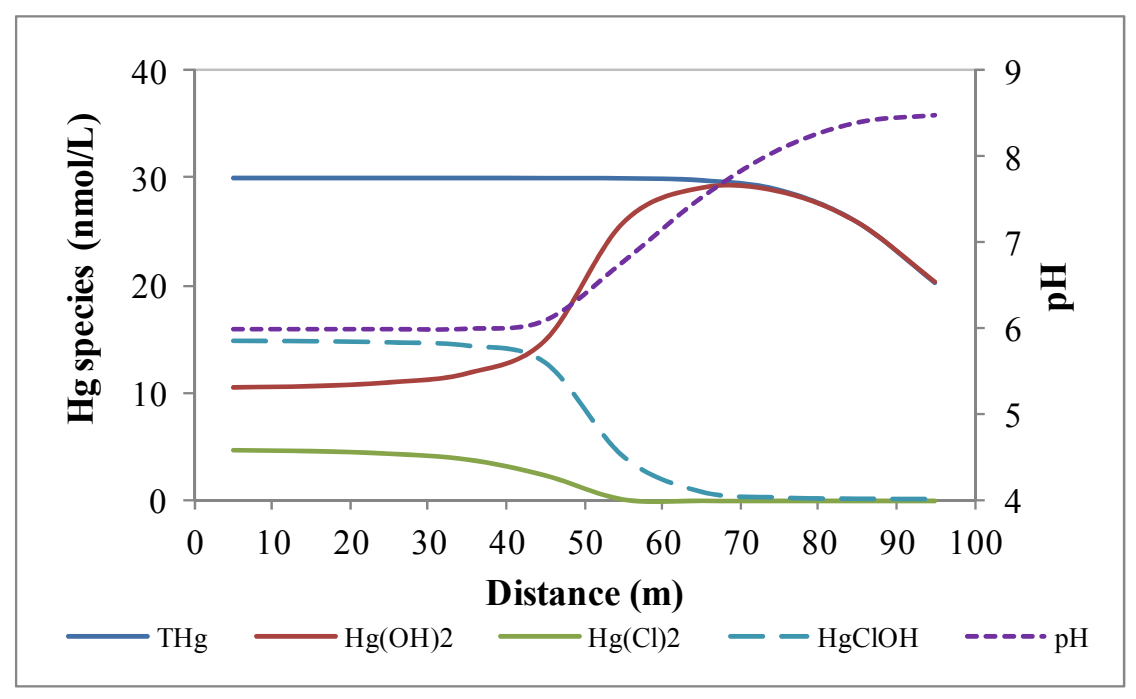

Figure $39 \mathrm{Hg}$-species flow profile in typical groundwater flow condition 
It can be seen in Figure 39 that the total $\mathrm{Hg}$ ( $\mathrm{THg}$ ) shows a conservative behavior and indicates the effect of dispersion at around the $70 \mathrm{~m}$ of distance from the start. The $\mathrm{pH}$ profile shows an increase at $50 \mathrm{~m}$. This is due to the effect of flow parameters on the mixing of 2 solutions. At $\mathrm{pH}$ lower than $6.3, \mathrm{HgClOH}$ is dominant with $50 \%$ of $\mathrm{THg}$, while $\mathrm{Hg}(\mathrm{OH})_{2}$ and $\mathrm{HgCl}_{2}$ are $35 \%$ and $15 \%$ respectively. The sharp increase of $\mathrm{pH}$ at 50 m (from 6 to 8.4) affects the distribution of Hg-species. Thus, $\mathrm{Hg}(\mathrm{OH})_{2}$ increases and reaches the maximum $\left(\mathrm{Hg}(\mathrm{OH})_{2}=\mathrm{THg}\right)$ at $70 \mathrm{~m}$, while $\mathrm{HgCl}_{2}$ and $\mathrm{HgClOH}$ decrease and disappear at $55 \mathrm{~m}$ and $70 \mathrm{~m}$ respectively. Using the typical groundwater flow condition, the travel time for the distance of $100 \mathrm{~m}$ is 125 days.

Scenario 2: With exchangers: Illite, Montmorillonite, and Vermiculite

In this scenario, the water quality and flow parameters are kept as those in scenario 1; the water quality and flow parameters in Table 40 and 43 were used in the simulations. However, in this scenario, the exchangers (Illite, Montmorillonite and Vermiculite) were individually added into cells 4 and 5 of the flow reach (Figure 40). This was to examine the effect of each exchanger with the role of ion exchange on $\mathrm{Hg}$ fate and transport in a typical groundwater flow environment. Four simulations were made 1) with Illite, CEC of $6.5 \mathrm{~mol} / \mathrm{L}, 2$ ) with Montmorillonite, CEC of $15 \mathrm{~mol} / \mathrm{L}, 3$ ) with Vermiculite, CEC of $26 \mathrm{~mol} / \mathrm{L}, 4)$ with Illite+Montmorillonite+Vermiculte, CEC of $47.5 \mathrm{~mol} / \mathrm{L}$. 

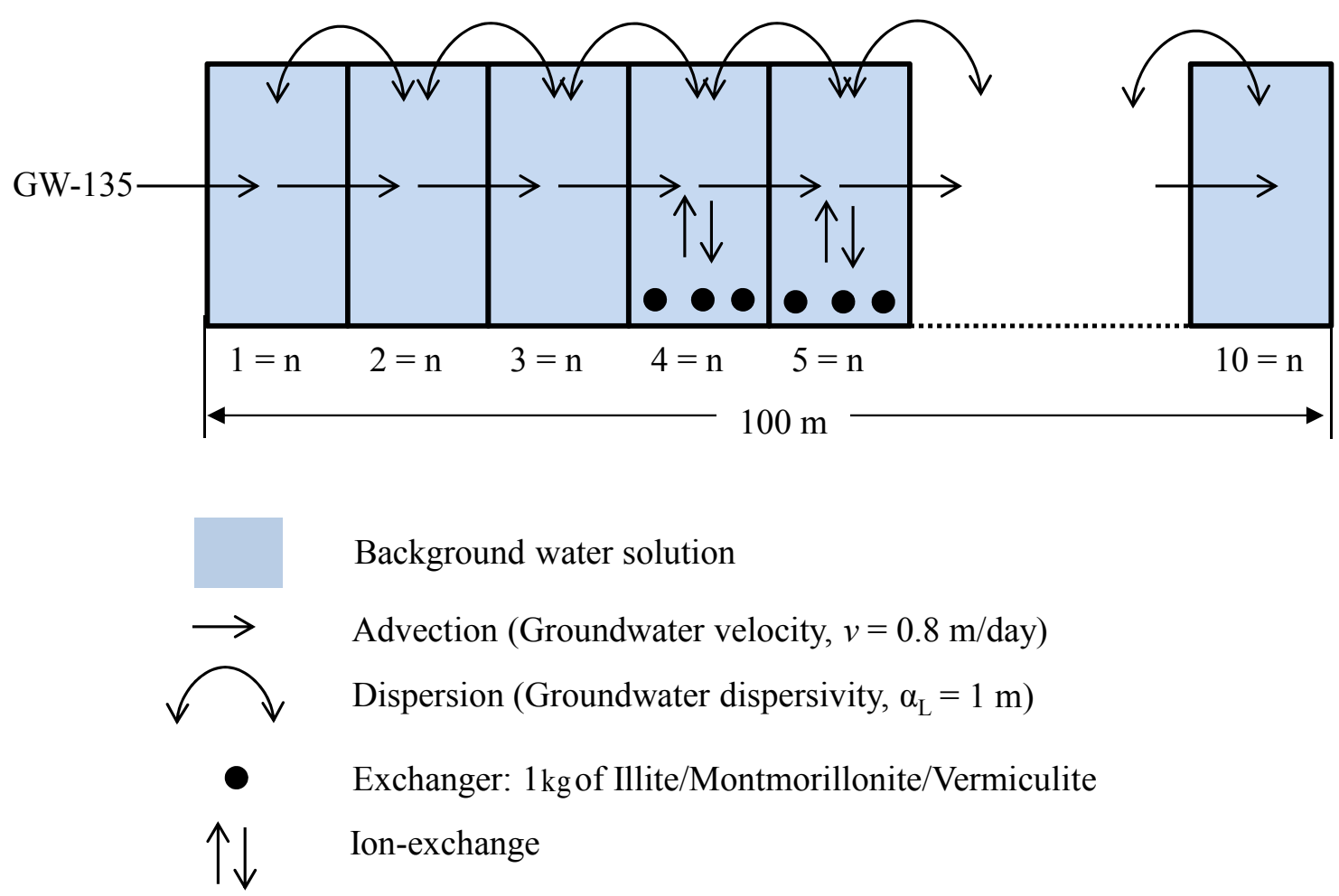

Figure 40 Model of $\mathrm{Hg}$ transport for a typical groundwater flow condition. Simulations were performed for each individual exchanger (Illite, Montmorillonite and Vermiculite)

Figure 41 (a) shows the comparison of dissolved THg concentration profiles, from which, it can be seen that dissolved THg concentration in cells 4 and 5 decrease with increase in CEC. In other words, the Hg sorption increases with CEC. Therefore, in this study, the exchange capacities (or sorption capacity) of the exchangers are in order of Vermiculite $>$ Montmorillonite $>$ Illite. The dissolved Hg-species profiles with Illite, Montmorillonite, and Vermiculite are shown in Figures 41 (b), (c), (d), respectively. 


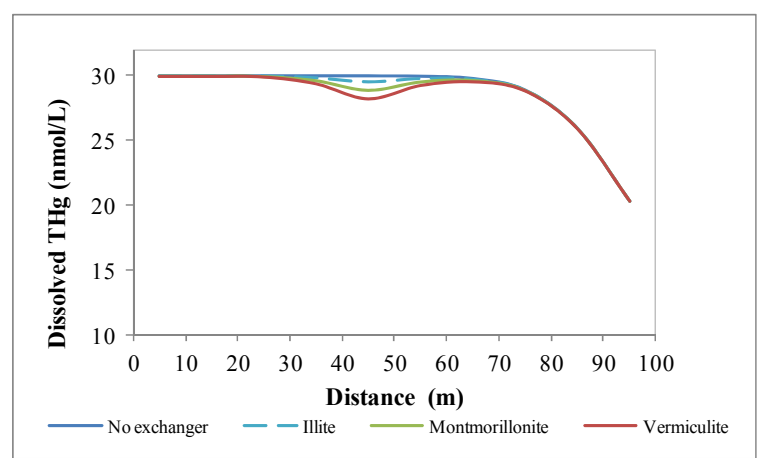

(a) THg with different exchangers

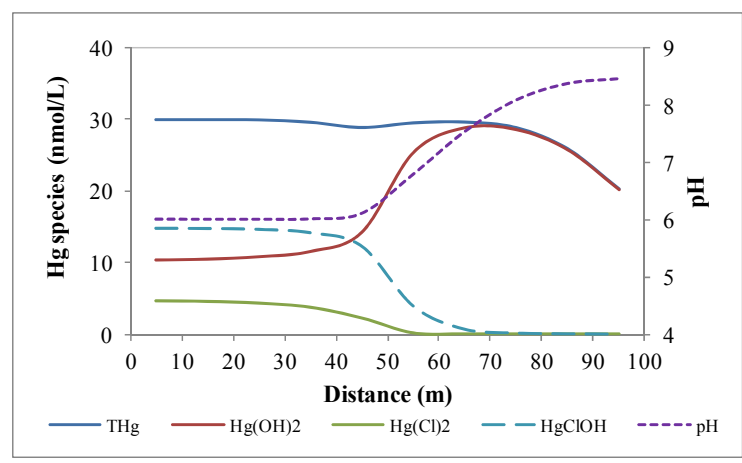

(c) Hg-species with 1 Montmorillonite exchanger

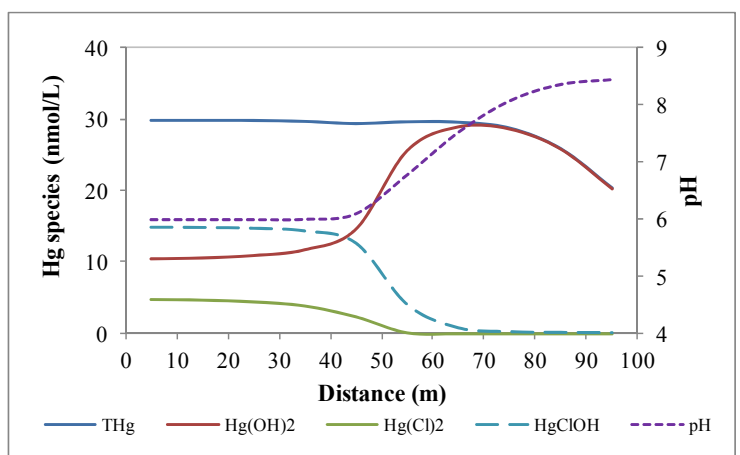

(b) Hg-species with Illite

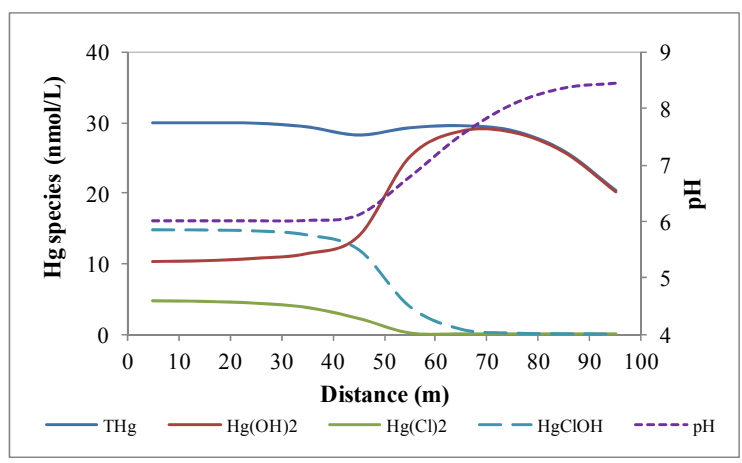

(d) Hg-species with Vermiculite exchanger

Figure 41 The effect of ion exchange on $\mathrm{Hg}$-species flow profiles for different exchangers (Illite, Montmorillonite and Vermiculite). The exchangers were individually applied to cells 4 and 5 ( 40 and $50 \mathrm{~m}$ of flow distance)

The Hg profiles do not show significant change with the exchangers. This can be attributed to the low exchange constant $\left(\mathrm{Hg}^{2+}+2 \mathrm{X}^{-}=\mathrm{HgX}_{2}, \log \mathrm{K}=-1.39\right) . \mathrm{Hg}(\mathrm{OH})_{2}$ is the main component that is sorbed by the exchangers. Water $\mathrm{pH}$ is not affected by the exchangers.

Scenario 3: With surface complexation: $\mathrm{Fe}(\mathrm{OH})_{3}$, Gibbsite, Kaolinite

The water quality and flow parameters in this scenario were the same as those employed in scenarios 1 and 2 . However, the different sorbents were individually added to cells 4 and 5 for this scenario. The goal was to determine the effect surface 
complexation on the Hg fate and transport. The sorbents that were chosen for this study $\left(\mathrm{Fe}(\mathrm{OH})_{3}\right.$, Gibbsite, and Kaolinite) are typically found in groundwater bedrock and streambed sediment.The schematic of the PHREEQC transport model for this scenario is shown in Figure 42.
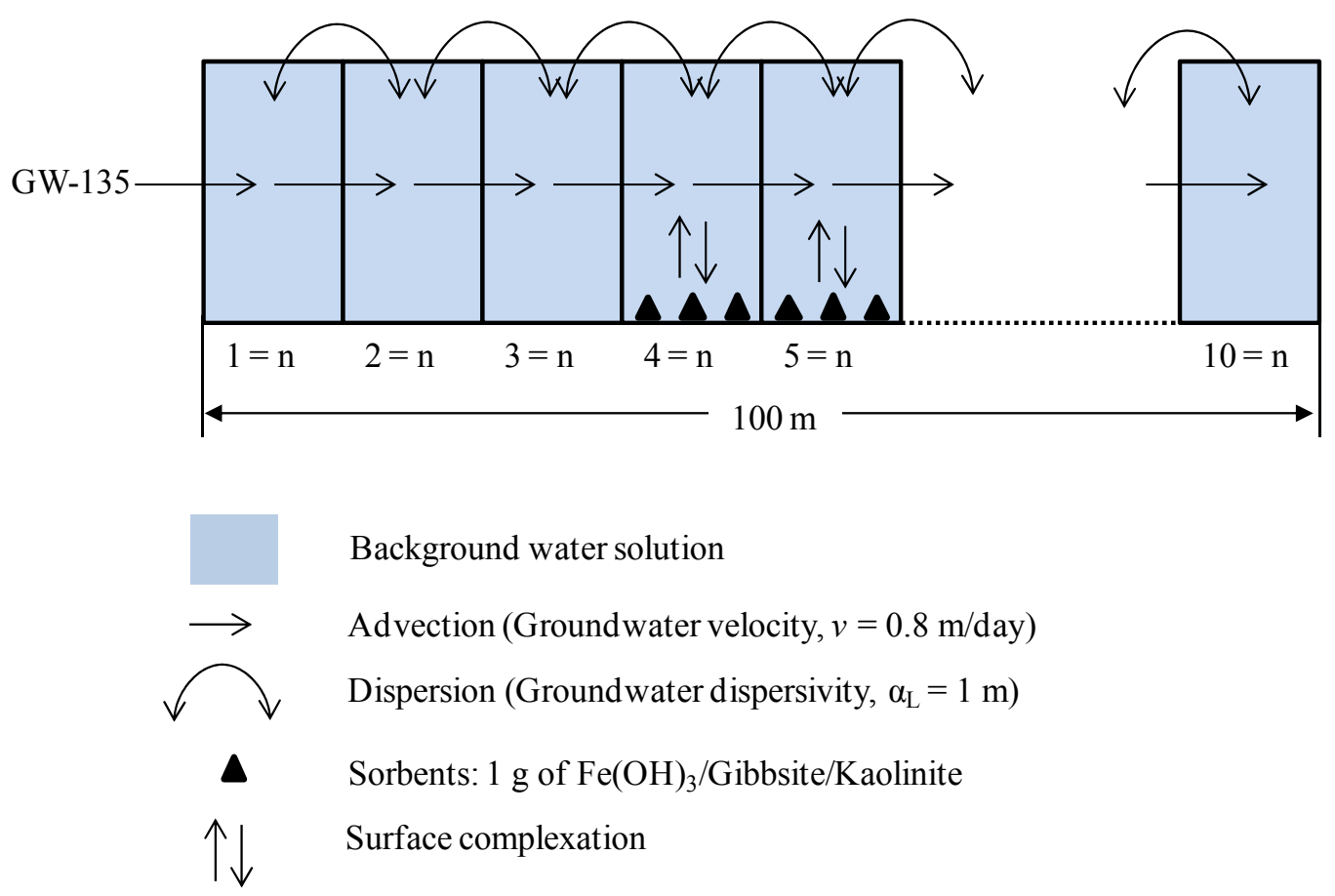

Figure 42 Model of $\mathrm{Hg}$ transport for a typical groundwater flow condition. Simulations were performed for each individual sorbents $\left(\mathrm{Fe}(\mathrm{OH})_{3}\right.$, Gibbsite and Kaolinite)

Figure 43 (a) shows the $\mathrm{THg}$ profile as a function of flow distance. With $\mathrm{Fe}(\mathrm{OH})_{3}$ sorbent, THg shows the sharp decrease in its concentration at $40 \mathrm{~m}$, where the surface complexation between $\mathrm{Hg}$ and $\mathrm{Fe}(\mathrm{OH})_{3}$ occurs. The surface complexation between $\mathrm{Hg}$ and $\mathrm{Fe}(\mathrm{OH})_{3}$ is so strong that most of $\mathrm{Hg}$ was sorbed and became negligible after $40 \mathrm{~m}$. Adding more than one type of sorbents, which is more representive of typical conditions in aqueous environments, increases the sorption capacity. However, since $\mathrm{Fe}(\mathrm{OH})_{3}$ has 
strong $\mathrm{Hg}$ sorption capability, the surface complexation between $\mathrm{Hg}$ and a combination of Kaolinite, Gibbsite, $\mathrm{Fe}(\mathrm{OH})_{3}$ sorbents, is mainly influenced by the $\mathrm{Fe}(\mathrm{OH})_{3}$.

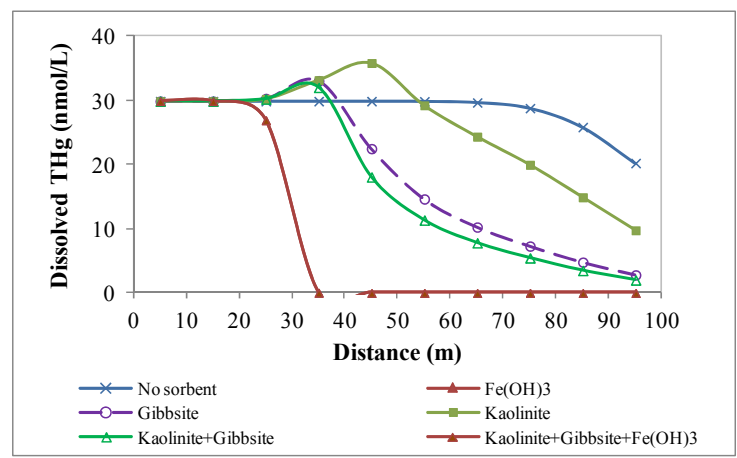

(a) THg profile with different sorbents

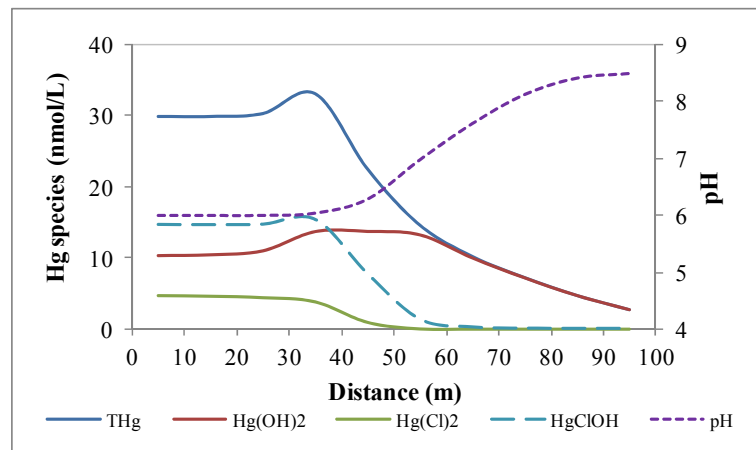

(c) Hg-species profile with $1 \mathrm{~g}$ of Gibbsite

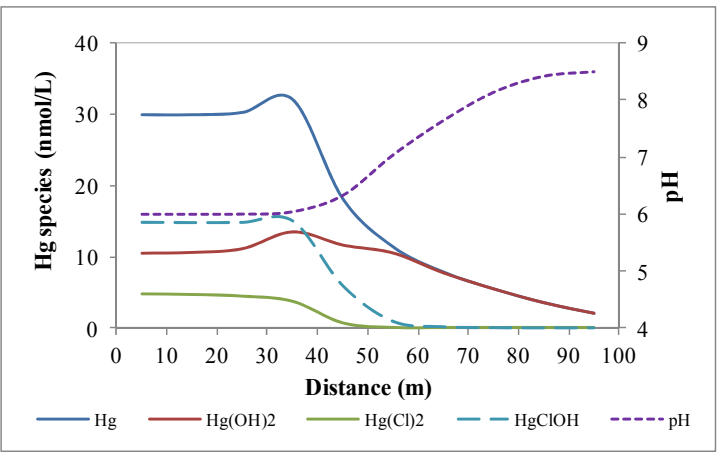

(e) Hg-species profile with $1 \mathrm{~g}$ of Kaolinite and Gibbsite

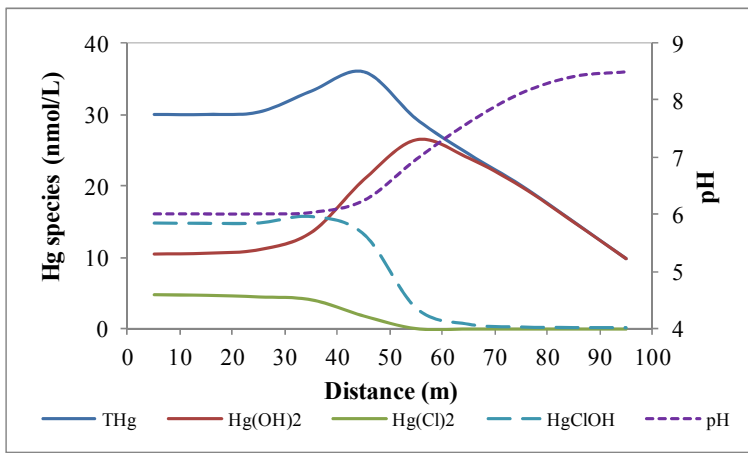

(b) $\mathrm{Hg}$-species profile with $1 \mathrm{~g}$ of Kaolinite

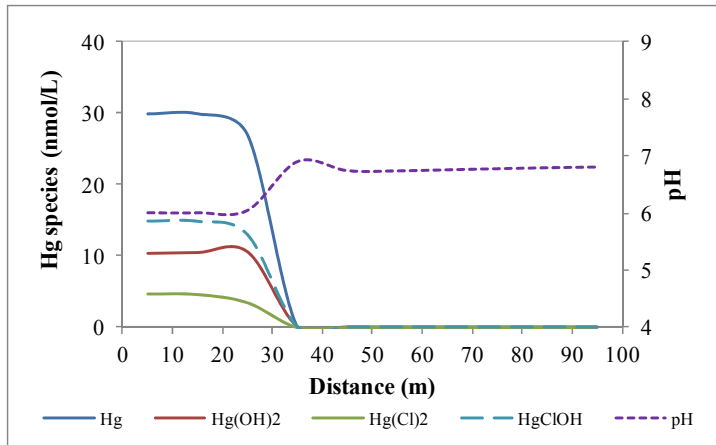

(d) $\mathrm{Hg}$-species profile with $1 \mathrm{~g}$ of $\mathrm{Fe}(\mathrm{OH})_{3}$

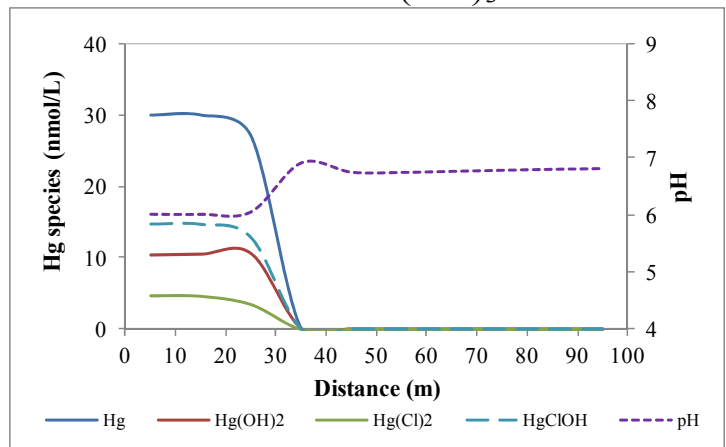

(f) $\mathrm{Hg}$-species profile with $1 \mathrm{~g}$ of Kaolinite, Gibbsite, and $\mathrm{Fe}(\mathrm{OH})_{3}$,

Figure 43 The effect of surface complexation on $\mathrm{Hg}$-species flow profiles for different sorbents $\left(\mathrm{Fe}(\mathrm{OH})_{3}\right.$, Gibbsite and Kaolinite).The sorbents were applied to cells 4 and 5 (40 and $50 \mathrm{~m}$ of flow distance) 
For this study, the sorption capacity of sorbents are in the order Kaolinite < Gibbsite $<$ Gibbsite + Kaolinite $<\mathrm{Fe}(\mathrm{OH})_{3}=\mathrm{Fe}(\mathrm{OH})_{3}+$ Gibbsite + Kaolinite. The Hgspecies and pH profiles with each sorbent are shown in Figures 43 (b) to (f).

It can be seen from Figures 43 (b) and (f) that water $\mathrm{pH}$ increases sharply between $35-40 \mathrm{~m}$. This is because of the effect of added $\mathrm{Fe}(\mathrm{OH})_{3}$. The logarithm of the surface complexation reaction constant, $\log \mathrm{K}$, of the reaction between $\mathrm{H}^{+}$and $\mathrm{Fe}(\mathrm{OH})_{3}$, (三Hfo_sOH $+\mathrm{H}^{+}=\equiv \mathrm{Hfo} \_s O H_{2}{ }^{+}$) is 7.29 . This implies that the $\mathrm{pH}$ of water should increase in the presence of $\mathrm{Fe}(\mathrm{OH})_{3}$. However, after the surface complexation reaction between $\mathrm{Hg}$ and $\mathrm{Fe}(\mathrm{OH})_{3}, \mathrm{pH}$ drops to a constant value of 7 . This is because some of the $\mathrm{H}^{+}$is released back to the water when $\mathrm{Hg}$ complexes with $\mathrm{Fe}(\mathrm{OH})_{3}$. In the presence of Kaolinite, $\mathrm{HgCl}_{2}$ and $\mathrm{HgClOH}$ are sorbed and becomes negligigble after 55 and $70 \mathrm{~m}$ respectively. The same happens at 50 and $60 \mathrm{~m}$ in the case of Gibbsite. Final THg concentrations at $100 \mathrm{~m}$ are 9.7, 2.8, 2.0 and $0 \mathrm{nmol} / \mathrm{L}$ in the presence of $1 \mathrm{~g}$ of Kaolinite, Gibbsite, Kaolinite + Gibbsite, and $\mathrm{Fe}(\mathrm{OH})_{3}$, respectively.

\subsubsection{Typical surface water flow}

This section describes the modeling performed on the $\mathrm{Hg}$ fate and transport in a typical surface water flow conditon. The same water quality data used previously to study the groundwater condition (Table 40) were used here. The typical surface water flow parameters in Table 42, which were reported in literature, were used for the simulations in this section. The Hg fate and transport in a typical surface water condition were studied for 3 different scenarios: 1) without exchangers and sorbents; 2) with exchangers; and 3) with sorbents. 
Table 42 Typical surface water flow parameters

\begin{tabular}{|c|c|c|c|}
\hline Parameters & ORR area & South Florida area & $\begin{array}{c}\text { Value } \\
\text { used in } \\
\text { this studv }\end{array}$ \\
\hline$u(\mathrm{~m} / \mathrm{d})$ & $\begin{array}{c}\text { 12,000 - } 17,000 \text { (Loar et } \\
\text { al., 2011 and Vasquez, } \\
\text { 2008) }\end{array}$ & $\begin{array}{l}20,000-47,000 \text { for Kissimmee river } \\
\text { (Campbell et al., 1995) } \\
432 \text { - } 800 \text { for ENP area (Harvey et al., } \\
\text { 2002) }\end{array}$ & 12,900 \\
\hline$\alpha_{L}(\mathrm{~m})$ & $\begin{array}{l}1-2,000 \text { or more for typical } \\
\text { river (Shen et al., 2010) }\end{array}$ & $\begin{array}{l}2 \text { - } 6 \text { for ENP area (Harvey et al., } \\
2002 \text { ) }\end{array}$ & 6 \\
\hline $\mathrm{D}_{\mathrm{L}}\left(\mathrm{m}^{2} / \mathrm{d}\right)$ & $\begin{array}{l}12,000-10^{7.5}(\text { calculated } \\
\left.\text { using } \mathrm{D}_{\mathrm{L}=}=\alpha_{\mathrm{L}} u+\mathrm{D}^{*}\right)\end{array}$ & $\begin{array}{l}24,000-10^{7.9} \text { (calculated using } \mathrm{D}_{\mathrm{L}=} \\
\left.\alpha_{\mathrm{L}} u+\mathrm{D}^{*}\right)\end{array}$ & 77,400 \\
\hline $\mathrm{D}^{*}\left(\mathrm{~m}^{2} / \mathrm{d}\right)$ & $\begin{array}{c}3 \times 10^{-8}-3 \times 10^{-6} \text { (Shen et al. } \\
2010)\end{array}$ & $3 \times 10^{-8}-3 \times 10^{-6}$ & $3 \times 10^{-7}$ \\
\hline
\end{tabular}

Scenario 1: Without exchangers and sorbents

As previously mentioned, the flow parameters for a typical surface water flow condition (Table 42) were used for this study. The travel distance was chosen to be the same as that employed for the groundwater modeling. The flow reach was $100 \mathrm{~m}$ long and was divided into 10 cells for PHREEQC calculation. The schematic of the Hg transport model for this scenario is shown in Figure 44. 

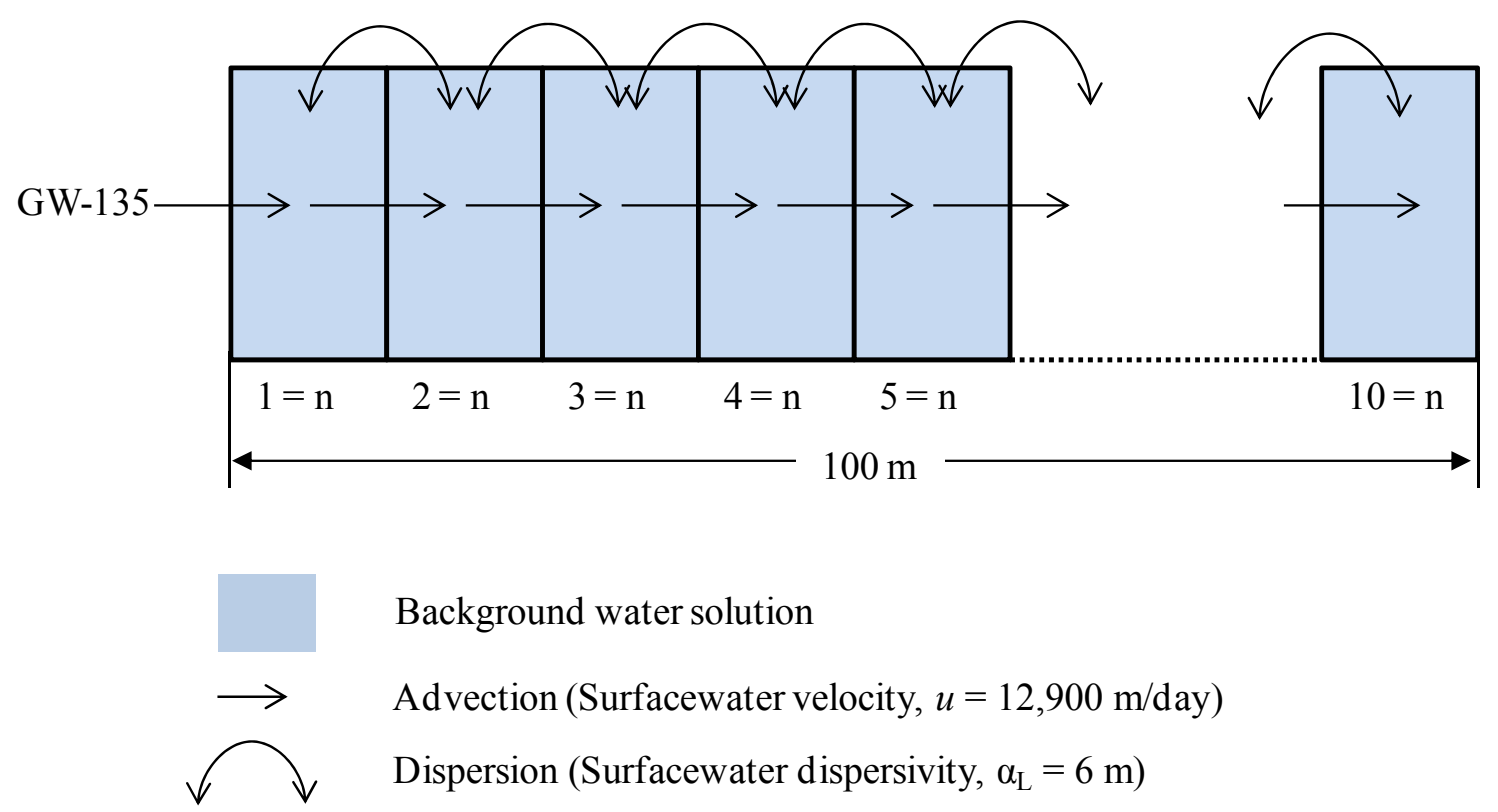

Figure 44 Model of $\mathrm{Hg}$ transport for a typical surface water flow condition

The water flows from GW-135 through the reach without any interactions between $\mathrm{Hg}$ and the solid (exchanger/sorbent). PHREEQC calculated the Hg-species profile based on the water quality data and flow parameters that were provided (see Figure 45).

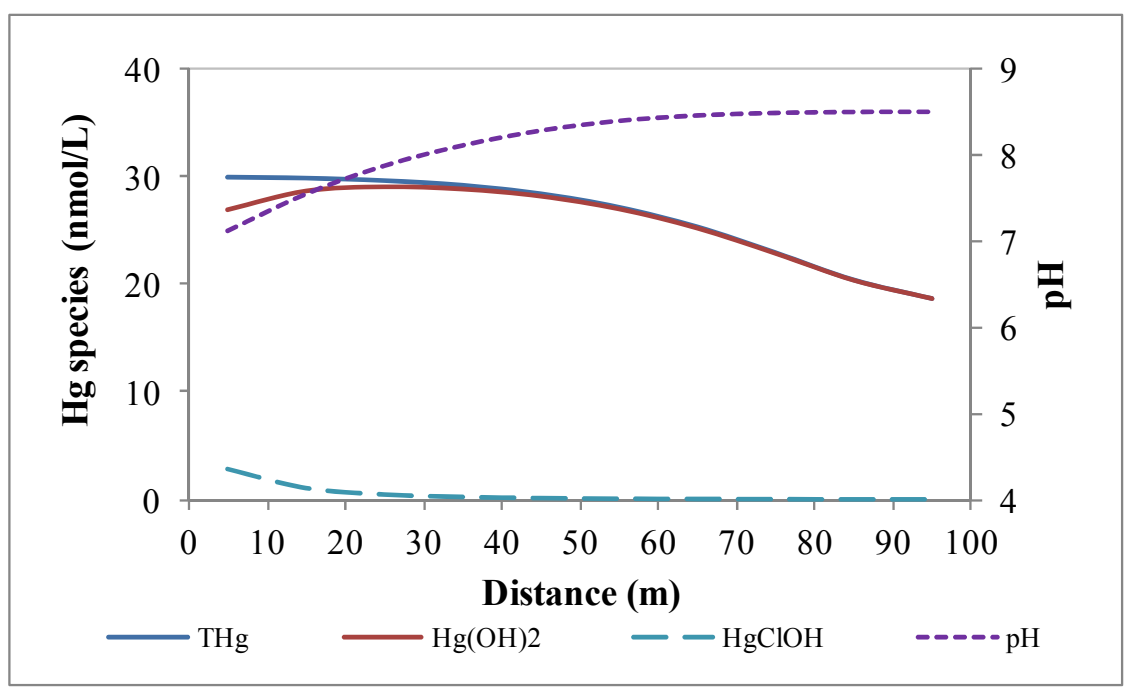

Figure $45 \mathrm{Hg}$-species flow profile in a typical surface water flow condition 
It can be inferred from Figure 45 that, with high velocity and dispersion, the Total $\mathrm{Hg}(\mathrm{THg})$ shows quite a conservative profile over the reach. The THg gradually reduces in concentration, presumably due to the effect of dispersion. There were only two Hgspecies $\left(\mathrm{Hg}(\mathrm{OH})_{2}, \mathrm{HgClOH}\right)$ that were observed throughout the flow distance. $\mathrm{HgClOH}$ was observed in the range of 10 to $30 \mathrm{~m}$. but became negligible afer $30 \mathrm{~m}$. The travel time of $11 \mathrm{~min}$ (for $100 \mathrm{~m}$ distance) was considerably quicker when compared to the transport in the groundwater flow (i.e., 125 days).

Scenario 2: With exchangers: Illite, Montmorillonite, and Vermiculite

The $\mathrm{Hg}$ fate and transport in a typical surface water flow environment was simulated with different exchangers (i.e., Illite, Montmorillonite and Vermiculite) that were individually added into cells 4 and 5 of the flow reach (Figure 46). This was to examine the effect of ion exchange of each exchanger on $\mathrm{Hg}$ fate and transport. The water quality and the travel distance were identical to scenario 1 . The same type of exchangers and CEC used in the groundwater scenario were used for simulations herein. These were 1) Illite, CEC of $6.5 \mathrm{~mol} / \mathrm{L}, 2$ ) Montmorillonite, CEC of $15 \mathrm{~mol} / \mathrm{L}, 3$ ) Vermiculite , CEC of $26 \mathrm{~mol} / \mathrm{L}$ and 4) Illite+Montmorillonite+Vermiculte, CEC of 47.5 mol/L. Four simulations with different exchangers were conducted. The schematic of the transport model is presented in Figure 46. 

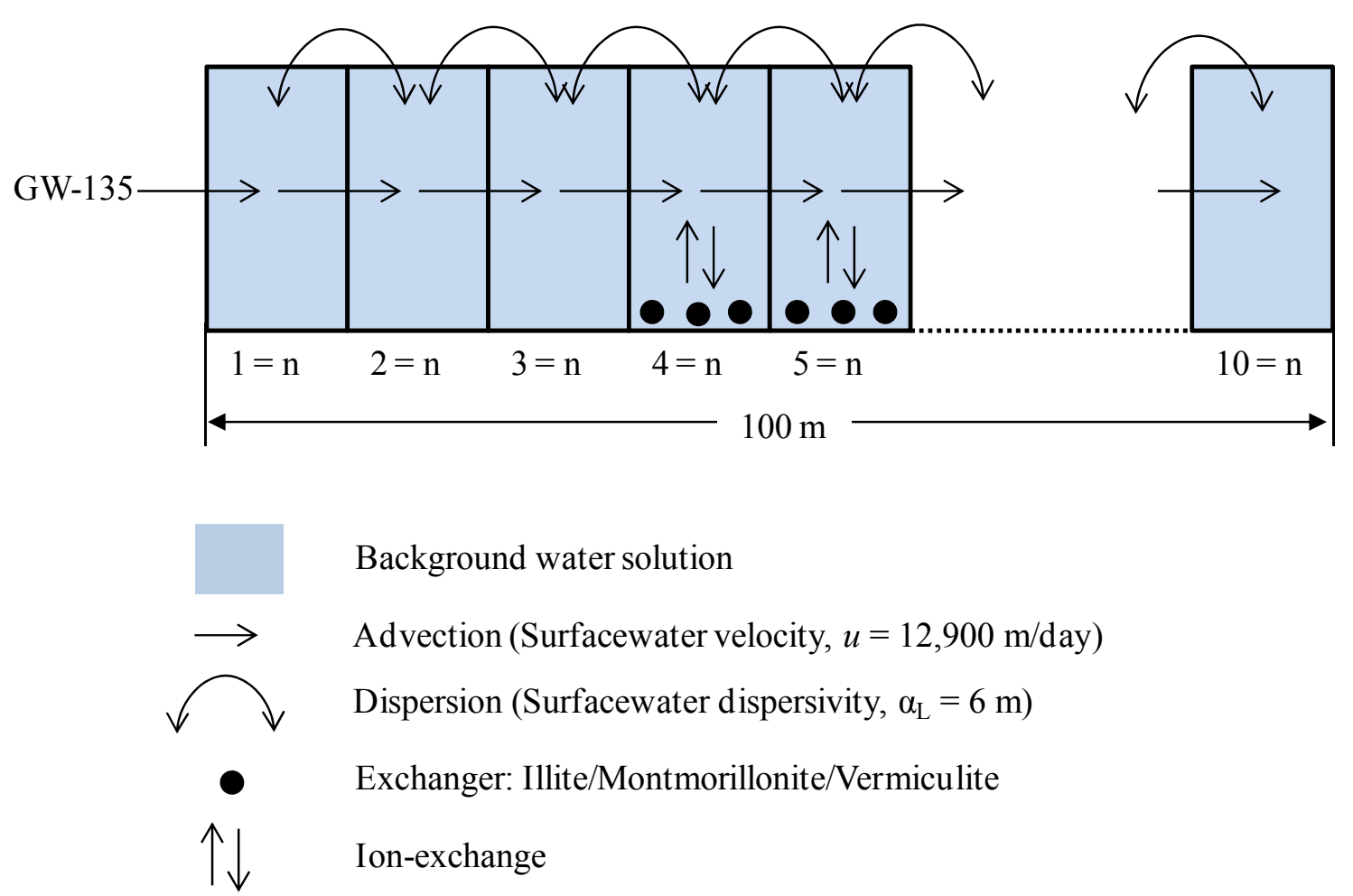

Figure 46 Model of $\mathrm{Hg}$ transport for a typical surface water flow condition. Simulations were performed for each individual exchanger (Illite, Montmorillonite and Vermiculite)

A significant difference was observed in the results obtained for surface water flow when compared to groundwater flow condition. The effect of dispersion on the concentration of $\mathrm{Hg}$ was more dominant when compared to the effect of ion exchange. There was no change in $\mathrm{THg}$ profiles when different exchangers were used along with the surface water flow condition of Table $42\left(u=12,900 \mathrm{~m} /\right.$ day and $\left.\alpha_{\mathrm{L}}=6 \mathrm{~m}\right)$. To further understand the effect of dispersion, a sensitivity analysis of $\mathrm{Hg}$ concentration to dispersivity along the travel distance was performed for 5 different conditions (Table 43). This was performed only for Vermiculite exchanger (Vermiculite has higher CEC compared to the other exchangers). 
Table 43 Conditions used for sensitivity analysis of dispersion to exchange reaction between $\mathrm{Hg}$ and Vermiculite

\begin{tabular}{|cccc|}
\hline Condition & $\mathbf{U}(\mathbf{m} / \mathbf{d a y})$ & $\boldsymbol{\alpha}_{\mathbf{L}}(\mathbf{m})$ & $\begin{array}{c}\text { CEC of Vermiculite in } \\
\text { cells } \mathbf{4} \text { and } \mathbf{5}(\mathbf{m o l} / \mathbf{L})\end{array}$ \\
\hline 1 & 12,900 & No dispersion & No exchanger \\
\hline 2 & 12,900 & 2 & 26 \\
\hline 3 & 12,900 & 6 & 26 \\
\hline 4 & 12,900 & 20 & 26 \\
\hline 5 & 12,900 & & 26 \\
\hline
\end{tabular}

Results in Figure 47 show that for condition 1, without dispersion and ion exchange, a constant concentration of $\mathrm{THg}$, i.e. $30 \mathrm{nmol} / \mathrm{L}$, is obtained throughout the travel distance. For condition 2, with $2 \mathrm{~m}$ of dispersivity and $26 \mathrm{~mol} / \mathrm{L}$ of CEC, the dip in concentration of THg obtained at cells 4 and 5 (where the exchanger was added) is due to the ion-exchange reaction. The concentration also gradually reduces during 70-100 m due to dispersion. 


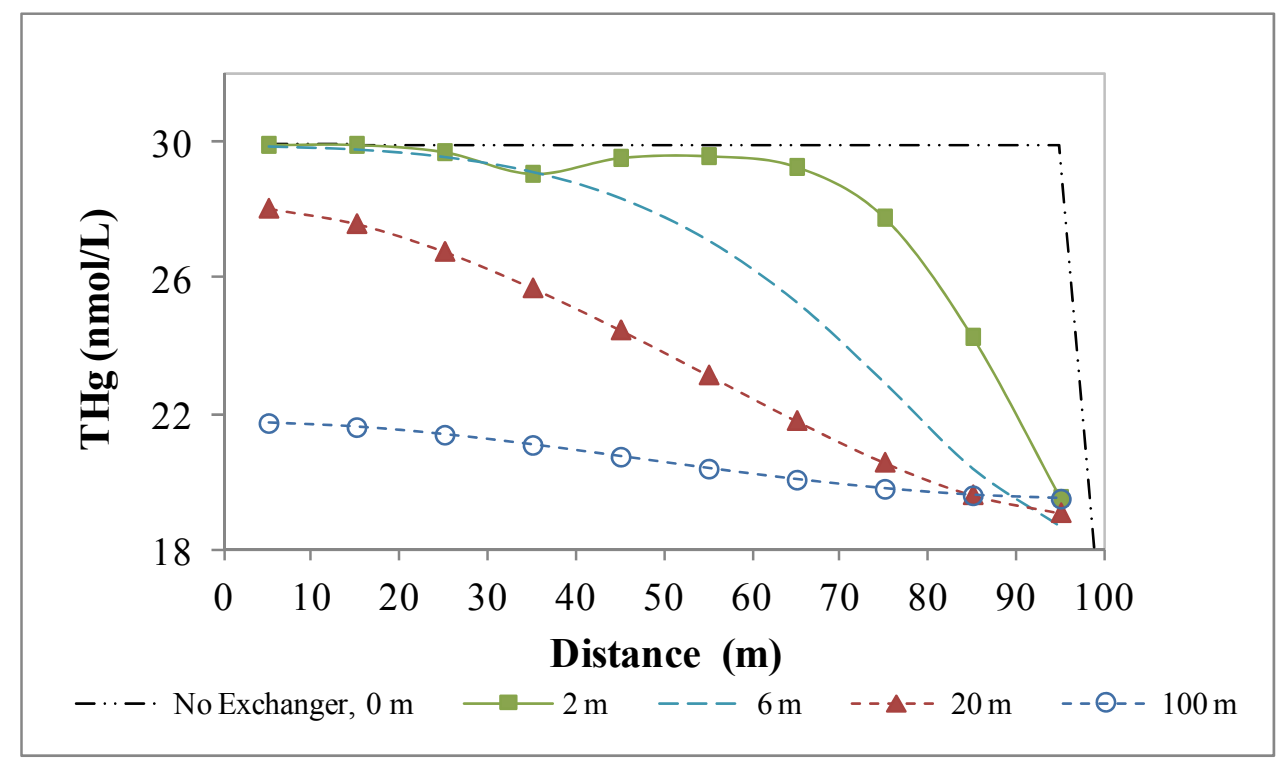

Figure 47 Effect of dispersion on the exchange reaction and $\mathrm{Hg}$ transport for surface water flow condition

The THg concentration changes along the travel distance for conditions 3 , 4, and 5, which were $26 \mathrm{~mol} / \mathrm{L} \mathrm{CEC} \mathrm{of} \mathrm{Vermiculite} \mathrm{and} \mathrm{dispersivity} \mathrm{of} 6 \mathrm{~m}, 20 \mathrm{~m}$, and $100 \mathrm{~m}$. There was no dip in concentration in cells 4 and 5 (where ion exchange is expected to take place) unlike that observed in condition 2. It can be inferred that, keeping all the other parameters constant, lower dispersivty $(\sim 2 \mathrm{~m})$ is required to see the effect of ion exchange under surface water flow condition. Since, the dispersivity for typical surface flow condition is $6 \mathrm{~m}$, it can be concluded that the $\mathrm{Hg}$ concentration as predicted by this model is dominated by dispersion instead of ion exchange.

Scenario 3: With surface complexation: $\mathrm{Fe}(\mathrm{OH})_{3}$, Gibbsite, Kaolinite

The water quality and flow parameters in this scenario were the same as those employed in scenarios 1 and 2. The goal was to determine the effect surface complexation on the $\mathrm{Hg}$ fate and transport. One $\mathrm{g} / \mathrm{L}$ of different sorbents: $\mathrm{Fe}(\mathrm{OH})_{3}$, 
Gibbsite, and Kaolinite, were individually added into cells 4 and 5 of the flow reach. The schematic of the transport setting is shown in Figure 48.
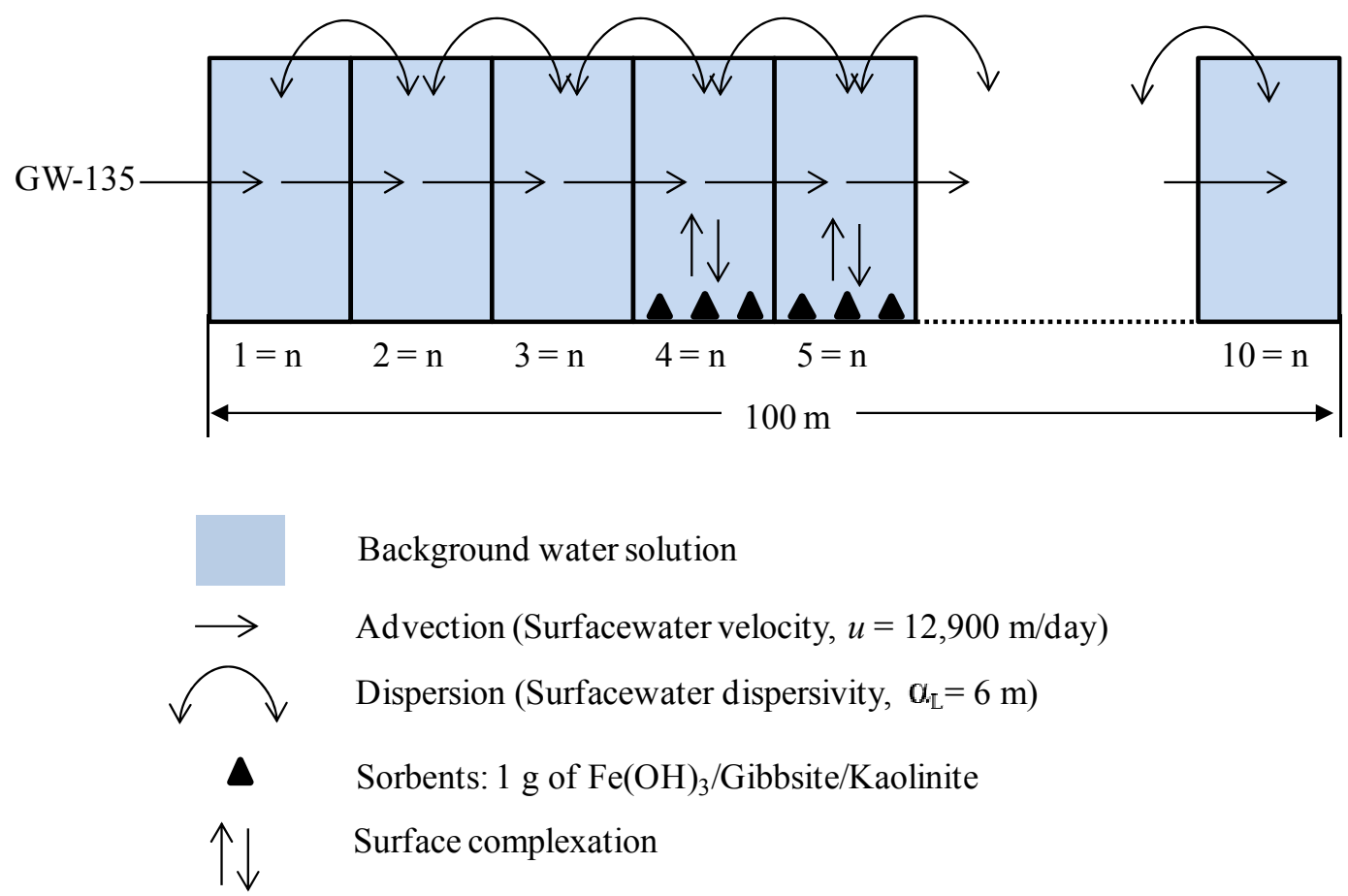

Figure $48 \mathrm{Model}$ of $\mathrm{Hg}$ transport for a typical surface water flow condition. Simulations were performed for each individual sorbents $(\mathrm{Fe}(\mathrm{OH}) 3$, Gibbsite and Kaolinite)

Figure 49 (a) shows the THg profile along the flow distance. It was observed that the sorption capacity of sorbents is in the order Kaolinite $<$ Gibbsite $<$ Kaolinite + Gibbsite $<\mathrm{Fe}(\mathrm{OH})_{3}=$ Kaolinite + Gibbsite $+\mathrm{Fe}(\mathrm{OH})_{3}$. The Hg-species and $\mathrm{pH}$ profiles for each sorbent are shown in Figures 49 (b) to (f). 


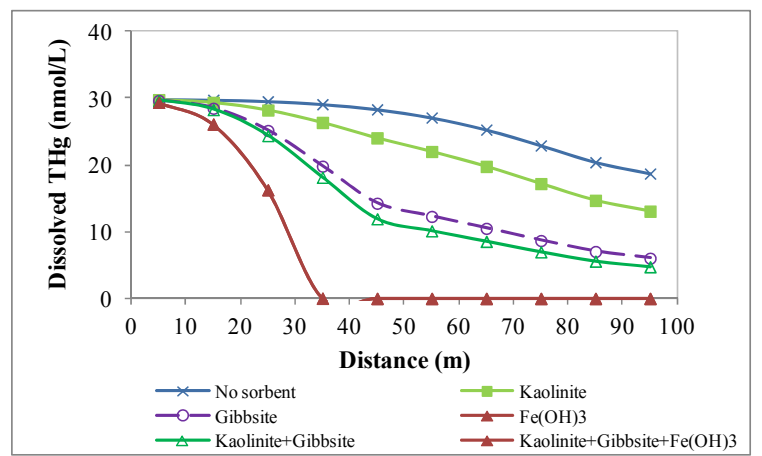

(a) $\mathrm{THg}$ profile with different sorbents

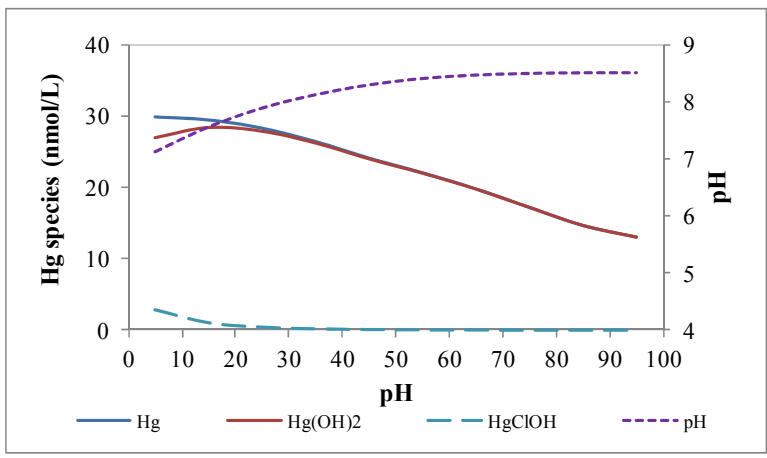

(b) $\mathrm{Hg}$-species profile with $1 \mathrm{~g}$ of Kaolinite

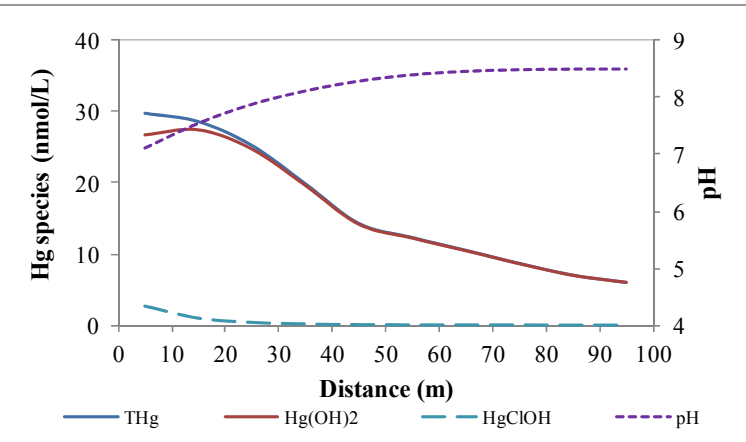

(c) Hg-species profile with $1 \mathrm{~g}$ of Gibbsite

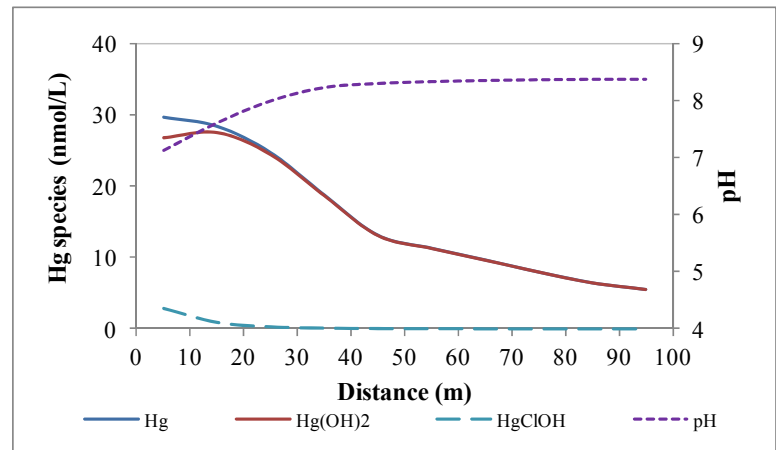

(e) Hg-species profile with $1 \mathrm{~g}$ of Kaolinite and Gibbsite

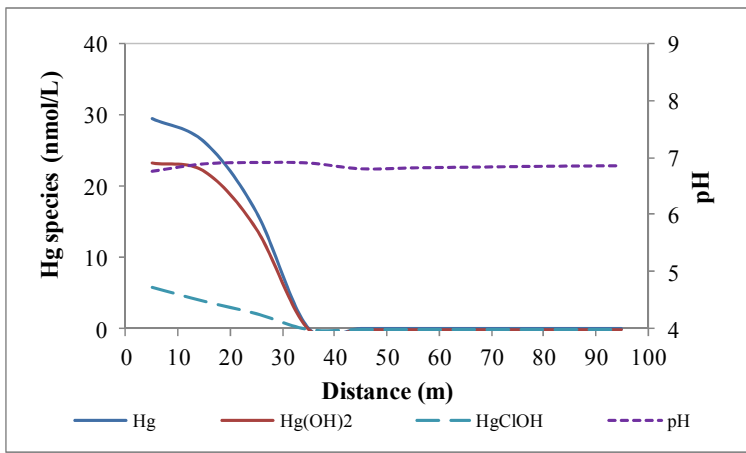

(d) $\mathrm{Hg}$-species profile with $1 \mathrm{~g}$ of $\mathrm{Fe}(\mathrm{OH})_{3}$

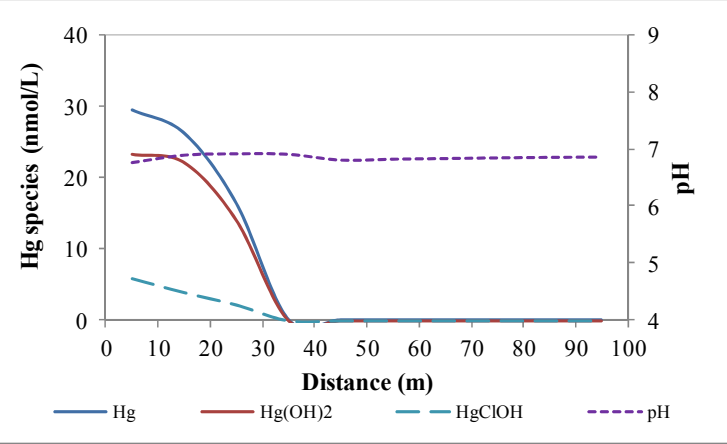

(f) $\mathrm{Hg}$-species profile with $1 \mathrm{~g}$ of Kaolinite, Gibbsite, and $\mathrm{Fe}(\mathrm{OH})_{3}$

Figure 49 The effect of surface complexation on $\mathrm{Hg}$-species flow profiles for different sorbents $\left(\mathrm{Fe}(\mathrm{OH})_{3}, \mathrm{Gibbsite}\right.$ and Kaolinite). The sorbents were applied to cells 4 and 5 (40 and $50 \mathrm{~m}$ of flow distance)

The water $\mathrm{pH}$ in the presence of $\mathrm{Fe}(\mathrm{OH})_{3}$, as shown in Figures 49 (d) and (f), is expected to increase because of surface complexation of $\mathrm{H}^{+}$and $\mathrm{Fe}(\mathrm{OH})_{3}$; but the reaction 
between $\mathrm{Hg}$ and $\mathrm{Fe}(\mathrm{OH})_{3}$ reduces the $\mathrm{pH}$, to a $\mathrm{pH}$ of 7 as shown in (d) and (f). A small drop in THg concentration was observed in the presence of Gibbsite, which is shown in (b) and (e). That could be due to the high surface complexation constant between $\mathrm{Hg}$ and Gibbsite. The surface complexation between $\mathrm{Hg}$ and $\mathrm{Fe}(\mathrm{OH})_{3}$ is also very strong. This explains why the $\mathrm{Hg}$ complexation is influenced by $\mathrm{Fe}(\mathrm{OH})_{3}$, when a mixture of Kaolinite + Gibbsite $+\mathrm{Fe}(\mathrm{OH})_{3}$ is used. The reaction between $\mathrm{HgClOH}$ and Kaolinite is stronger than that between $\mathrm{HgClOH}$ and Gibbsite, while Gibbsite can complex with $\mathrm{Hg}(\mathrm{OH})_{2}$ better than Kaolinite. 


\section{MODEL APPLICATIONS, RESULTS AND DISCUSSION}

This section presents the application of the enhanced model to assess the geochemical processes, fate, and transport of $\mathrm{Hg}$ for the two field test-beds (ORR, and ENP). Using specific water quality data obtained from each site, the sensitivity analysis to $\mathrm{pH}$ and temperature of $\mathrm{Hg}$-species was conducted in batch mode. For ORR test-bed, Hg transport in groundwater (Bear Creek Valley Regime) and surface water (EFPC) were investigated. For ENP test-bed, the Hg transport in the surface water of the Shark River Slough, was studied. The results yielded a better understanding of the fate and transport of $\mathrm{Hg}$ in these settings thereby aiding the selection of suitable restoration.

\subsection{ORR Test-Bed Simulations - Batch Mode}

In this section, the improved PHREEQC model was used to simulate the behavior of $\mathrm{Hg}$ in EFPC water located in the ORR area. The distribution of $\mathrm{Hg}$ species, the sensitivity analysis of $\mathrm{Hg}$-species and saturation index (SI) of minerals to water $\mathrm{pH}$ and water temperature were investigated. The simulations were conducted using the EFPC water quality data which is shown in Table 44 (Dong et al., 2010). The ORR and EFPC soil characteristics (physical and chemical properties) are described in Appendix E. 
Table 44 EFPC water quality data (Dong et al., 2010)

\begin{tabular}{|c|c|}
\hline Constituent & Range \\
\hline pe & 3.81 \\
\hline $\mathrm{pH}$ & $7.0-9.2$ \\
\hline Total Ca, mol/L & $7.7 \times 10^{-4}-1.1 \times 10^{-3}$ \\
\hline Total Mg, mol/L & $4.5 \times 10^{-4}-4.8 \times 10^{-4}$ \\
\hline Total Na, mol/L & $7.7 \times 10^{-4}-1.1 \times 10^{-3}$ \\
\hline Total K, mol/L & $5.0 \times 10^{-5}-9.0 \times 10^{-5}$ \\
\hline Total Fe, mol/L & $2.6 \times 10^{-8}-2.8 \times 10^{-8}$ \\
\hline Total $\mathrm{Cl}, \mathrm{mol} / \mathrm{L}$ & $2.2 \times 10^{-4}-6.5 \times 10^{-4}$ \\
\hline Total $\mathrm{HCO}_{3}, \mathrm{~mol} / \mathrm{L}$ & $2.0 \times 10^{-3}-2.1 \times 10^{-3}$ \\
\hline Total $\mathrm{NO}_{3}, \mathrm{~mol} / \mathrm{L}$ & $1.0 \times 10^{-4}-2.8 \times 10^{-4}$ \\
\hline Total $\mathrm{PO}_{4}, \mathrm{~mol} / \mathrm{L}$ & $2.5 \times 10^{-6}-1.2 \times 10^{-5}$ \\
\hline Total Zn, mol/L & $1.6 \times 10^{-7}-2.6 \times 10^{-7}$ \\
\hline Total $\mathrm{Cu}, \mathrm{mol} / \mathrm{L}$ & $1.2 \times 10^{-8}-2.8 \times 10^{-8}$ \\
\hline Total Cd, mol/L & $5.2 \times 10^{-8}-1.3 \times 10^{-9}$ \\
\hline Total $\mathrm{Pb}, \mathrm{mol} / \mathrm{L}$ & $6.1 \times 10^{-10}-1.3 \times 10^{-9}$ \\
\hline Total $\mathrm{Hg}, \mathrm{mol} / \mathrm{L}$ & $5 \times 10^{-11}-4 \times 10^{-10}$ \\
\hline
\end{tabular}




\subsubsection{Hg Speciation Distribution}

The Hg species distribution in EFPC using the improved PHREEQC model and the EFPC water quality data of Table 44 is shown in Figure 50.

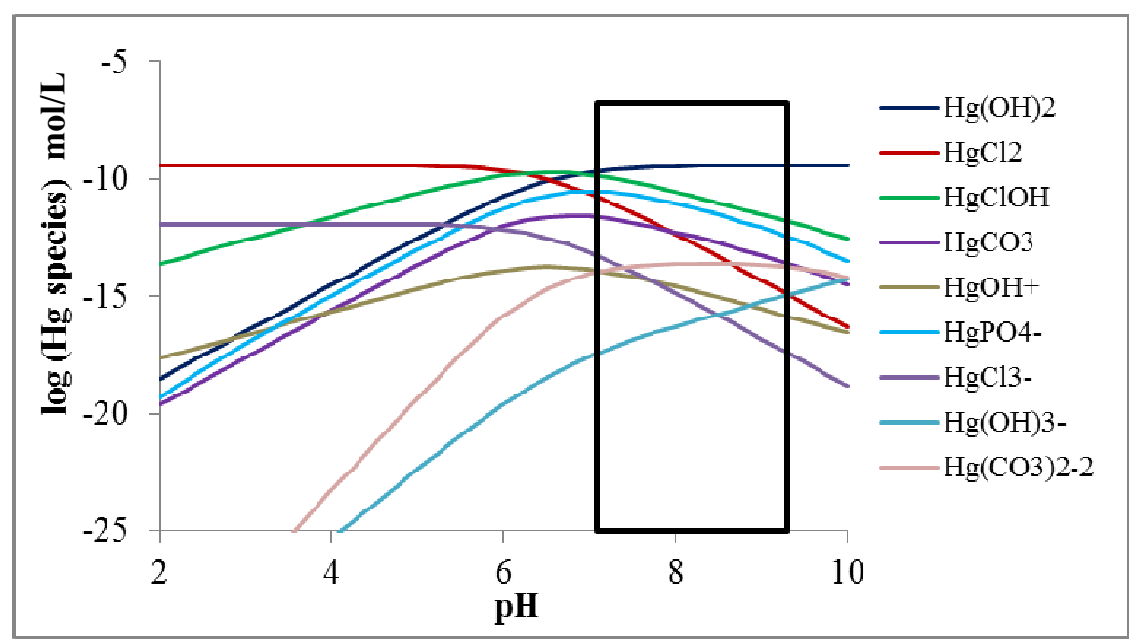

Figure $50 \mathrm{Hg}$ species distribution in EFPC water

The $\mathrm{Hg}(\mathrm{OH})_{2}$ is the dominant species at typical EFPC water $\mathrm{pH}$ (black box shown in Figure 50, $\mathrm{pH} \sim 7.0$ - 9.2). The second dominant species is $\mathrm{HgClOH}$. $\mathrm{Hg}(\mathrm{HO})_{2}$ concentration is low at low $\mathrm{pH}$, while $\mathrm{HgCl}_{2}$ dominates at low $\mathrm{pH}(0-6)$. The $\mathrm{Hg}(\mathrm{OH})_{2}$ concentration increases with water $\mathrm{pH}(0-6)$, while $\mathrm{HgCl}_{2}$ decreases. The higher concentration of $\mathrm{Hg}(\mathrm{OH})_{2}$ at high $\mathrm{pH}$ is due to the increase in $\mathrm{OH}$ with the water $\mathrm{pH}$.

\subsubsection{Sensitivity Analysis of Hg Species to Water Temperature and $\mathbf{p H}$}

The sensitivity of $\mathrm{Hg}$ speciation in EFPC to water temperature and $\mathrm{pH}$ was studied at temperatures in the range of $5-35^{\circ} \mathrm{C}$ and $\mathrm{pH} 2-10$ (Figure 51). 

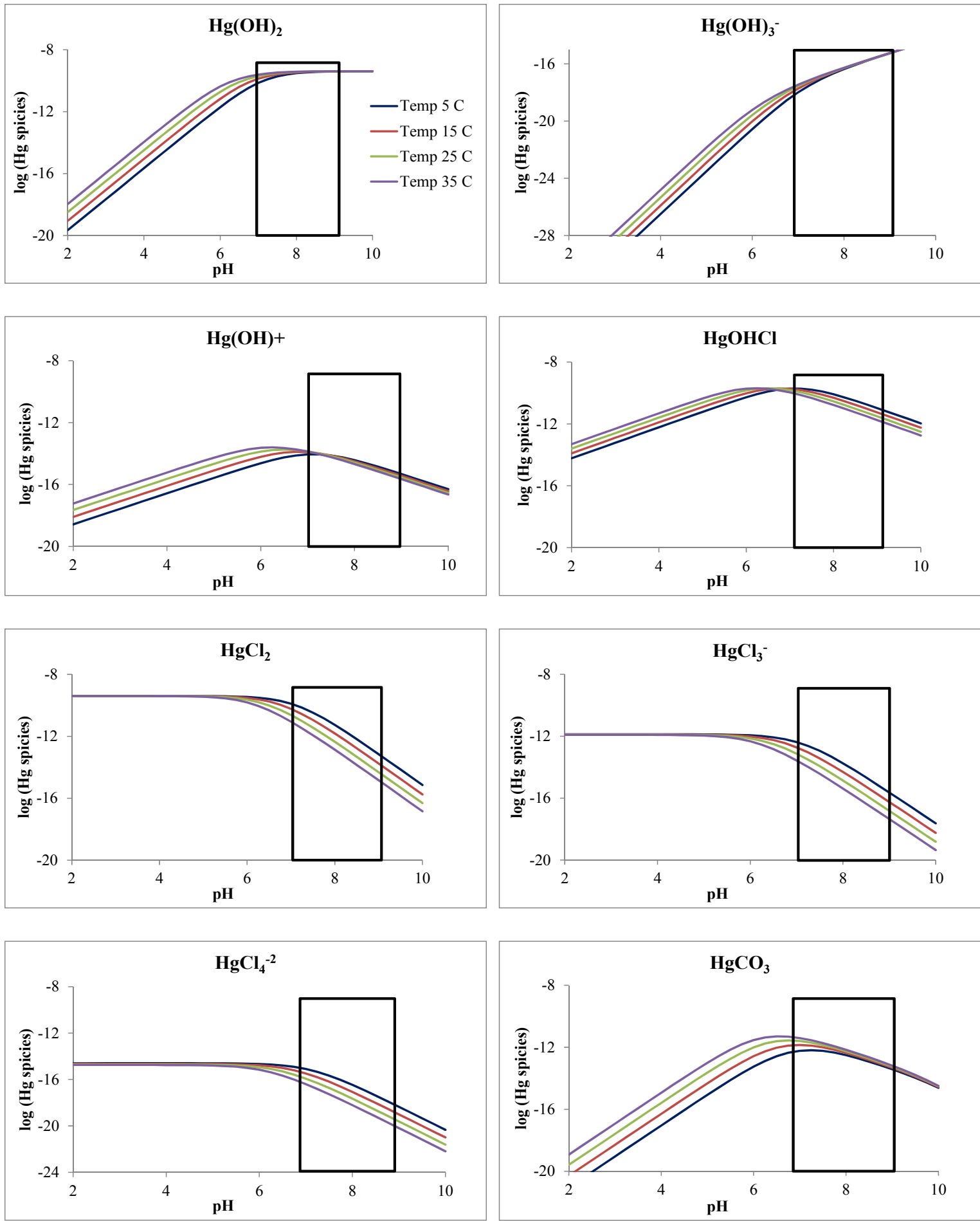

Figure $51 \mathrm{Hg}$ species sensitivity to temperature $\left(5-35^{\circ} \mathrm{C}\right.$ ) and $\mathrm{pH}(2-10)$ (unit in log mol/L); black box shows EFPC water $\mathrm{pH}$ range under oxidizing condition 
It can be seen from Figure 51 that the formation of $\mathrm{Hg}-\mathrm{OH}$ and $\mathrm{Hg}-\mathrm{CO}_{3}$ species increases with water temperature. An increase in water temperature does not favor the formation of $\mathrm{Hg}-\mathrm{Cl}$ species. An increase in water $\mathrm{pH}$ increases the formation of $\mathrm{Hg}(\mathrm{OH})_{2}$ and $\mathrm{Hg}(\mathrm{OH})_{3}{ }^{-}$. However, for $\mathrm{Hg}(\mathrm{OH})^{+}, \mathrm{HgOHCl}$, and $\mathrm{HgCO}_{3}$, the concentrations increased with $\mathrm{pH}$ between 2-7 and declined for $\mathrm{pH}>7$. Low water $\mathrm{pH}(\mathrm{pH} 2-6)$ does not have any influence on $\mathrm{Hg}-\mathrm{Cl}$ concentration. However, a decrease in its concentration is observed for $\mathrm{pH}>6$.

\subsubsection{Sensitivity Analysis of Mineral Saturation Index to Water Temperature and $\mathrm{pH}$}

The sensitivity analysis to water temperature and $\mathrm{pH}$ for the mineral precipitation at EFPC water conditions was conducted for temperature range of $5-35^{\circ} \mathrm{C}$ and for $\mathrm{pH}$ of 2-10 (Table 44). Figure 52 shows the effect of water temperature and $\mathrm{pH}$ on the SI of dominant precipitated minerals in EFPC water. The SI of Ferrihydrite, Goethite, Magnesioferrite, and Hematite increases with water temperature. However, temperature does not affect the formation of $\mathrm{FCO}_{3}$ Apatite, Lepidocrocite, Hydroxylapatite, and Arogonite. Increase in water $\mathrm{pH}$ favors the formation of all the above minerals since their

SI increases with water $\mathrm{pH}$. Within the EFPC water conditions, $\mathrm{pH}$ 7.0-9.2 and temperature $25^{\circ} \mathrm{C}$, water is supersaturated with Ferrihydrite, Goethite, Magnesioferrite, Hematite, $\mathrm{FCO}_{3}$ Apatite, Lepidocrocite, and Hydroxylapatite. Hence these minerals are excpected to precipitate at these conditions. At $\mathrm{pH} 8$, the EPFC water becomes saturated with Arogonite and its precipitation takes place. 

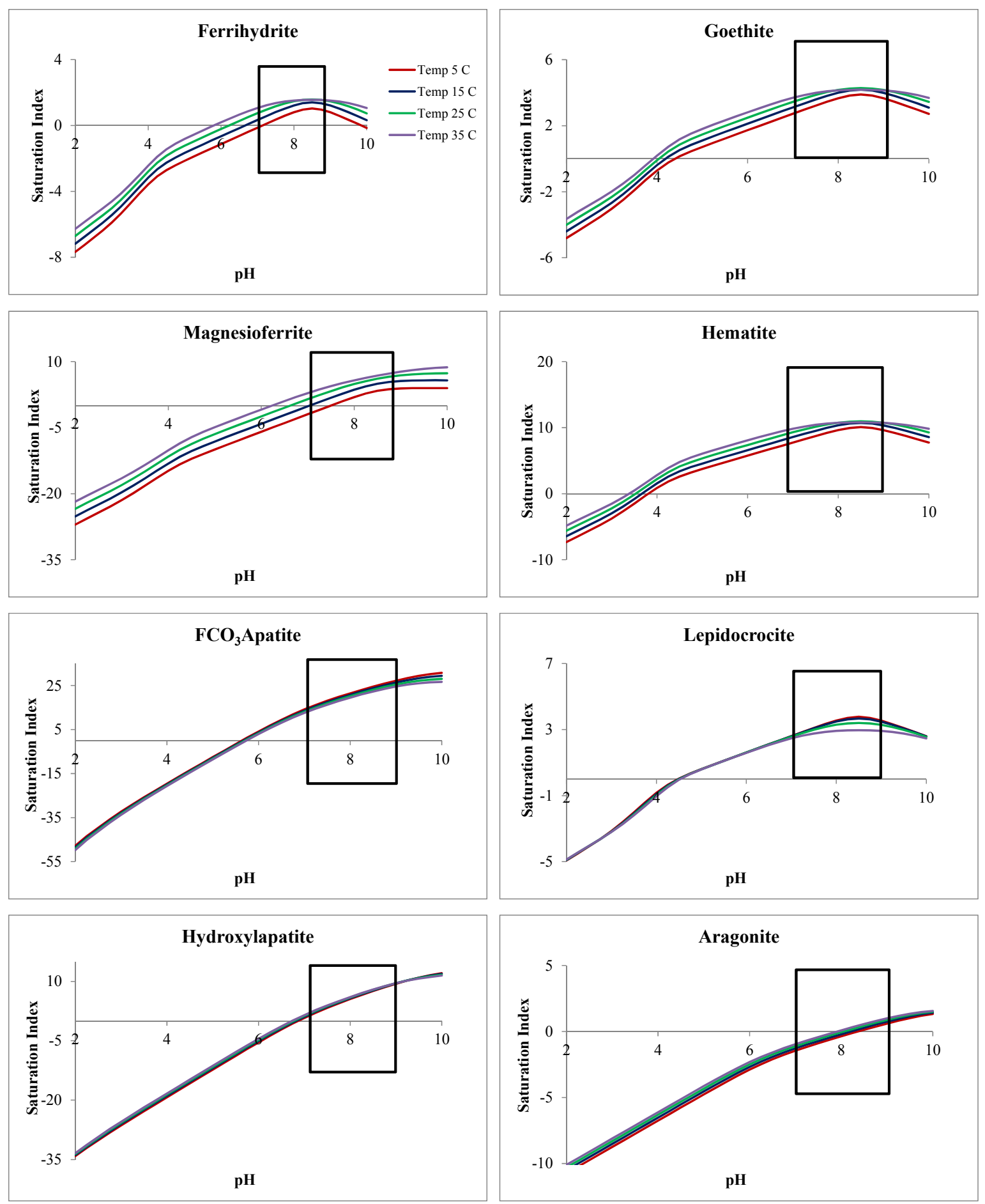

Figure 52 Sensitivity of mineral precipitation to water temperature and $\mathrm{pH}$ in EFPC water conditions 


\subsection{ORR Test-Bed Simulation - Groundwater Transport Mode}

\subsubsection{Hg in Groundwater Transport: Bear Creek Valley}

The transport of Hg in Bear Creek Valley, which is located in the ORR area is presented in this section. Data was collected from 4 monitoring wells: GW-916, GW-923, GW-363, GW-639. These wells were selected for the study because of 1) the availability of $\mathrm{Hg}$ data and 2) the wells were located in the main groundwater flow path as defined by the surface water table elevations. The locations of selected monitoring wells are shown in Figure 53.

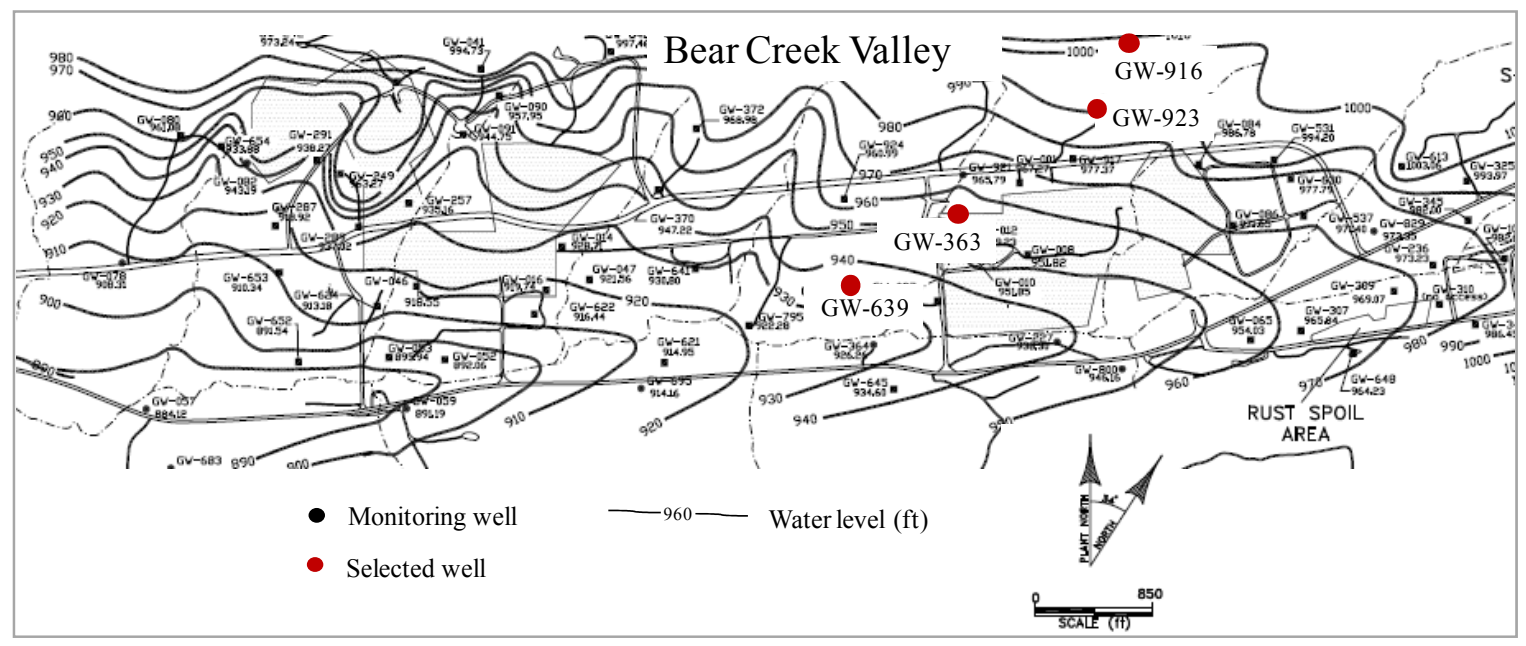

Figure 53 Location of selected wells for $\mathrm{Hg}$ transport in Bear Creek Valley, Oak Ridge, TN (modified after Elvado Environmental LLC, 2009)

The geology and soil bedrock of the site consist of shale, limestone, siltstone, and clay.

The soil consists of different minerals, such as Ferryhidrite, Gibbsite, Geothite, Illite and Kaolinite, etc. (Atre and Carpenter, 2010; Driese et al., 2001) (See Appendix E for soil characteristics); the CEC of $130 \mathrm{mmol} / \mathrm{L}$ was reported. The background water is a $\mathrm{Ca}-$ $\mathrm{Mg}-\mathrm{HCO}_{3}$ water. The average groundwater velocity of 0.66-1.0 m/day (Jago et al., 1995) 
and the dispersivity of $1 \mathrm{~m}$ (Stafford et al., 1998; Schulze-Makuch, 2005; Kelkar et al., 2006) were used in simulations herein. The water quality data at the selected wells and the flow parameters of the site that were used for the simulation are respectively shown in Tables 45 and 46.

Table 45 Water quality data used for $\mathrm{Hg}$ transport study in Bear Creek Valley (Elvado Environmental LLC, 2009 and 2011)

\begin{tabular}{|ccccc|}
\hline $\begin{array}{c}\text { Parameter } \\
\begin{array}{c}\text { Groundwater Elevation } \\
(\mathrm{ft})\end{array}\end{array}$ & $\mathbf{G W - 9 1 6}$ & $\mathbf{G W - 9 2 3}$ & $\mathbf{G W - 3 6 3}$ & GW-639 \\
\hline $\begin{array}{c}\text { Dissolved Oxygen } \\
(\mathrm{mg} / \mathrm{L})\end{array}$ & $0.2-0.9$ & 983 & 953 & 930 \\
\hline $\begin{array}{c}\text { Oxidation/Reduction } \\
(\mathrm{mV})\end{array}$ & $-105-15$ & $-10-19$ & $31-127$ & $78-98$ \\
\hline Temperature $\left({ }^{\circ} \mathrm{C}\right)$ & $13.9-14.3$ & $15.6-16.3$ & $14.5-21.5$ & $12.3-17$ \\
\hline $\mathrm{pH}$ & $7.1-8.0$ & $7.2-6.2$ & $8.6-9.3$ & $8.0-9.0$ \\
\hline Aluminum $(\mathrm{mg} / \mathrm{L})$ & - & - & 26.6 & 28.0 \\
\hline Calcium $(\mathrm{mg} / \mathrm{L})$ & $35.7-43.1$ & $48.3-33.8$ & $1.0-1.2$ & $0.9-0.8$ \\
\hline Magnesium $(\mathrm{mg} / \mathrm{L})$ & $5.8-47.0$ & $18.0-10.0$ & $0.26-0.49$ & $0.2-0.2$ \\
\hline Sodium $(\mathrm{mg} / \mathrm{L})$ & $24.6-32.0$ & $26.4-4.1$ & $1.04-1.18$ & $1.9-2.1$ \\
\hline Iron $(\mathrm{mg} / \mathrm{L})$ & $1.3-1.6$ & $1.7-28.3$ & $0.05-0.07$ & $0.1-0.2$ \\
\hline Mercury $(\mathrm{ng} / \mathrm{L})$ & $110-100$ & $72-130$ & $80-91$ & $80-90$ \\
\hline SI of Cinnabar & -9.6 & 5.9 & -36.8 & -41.8 \\
\hline SI of Fe(OH) & -1.2 & -1.7 & 2.9 & 3.1 \\
\hline SI of Gibbsite & - & - & 0.3 & 0.1 \\
\hline
\end{tabular}

Table 46 Groundwater flow parameters used for $\mathrm{Hg}$ transport in Bear Creek Valley simulations (Jago et al., 1995; Kelkar et al., 2006)

\begin{tabular}{|ccc|}
\hline Parameters & ORR area & Value used in this study \\
\hline$v(\mathrm{~m} / \mathrm{d})$ & $0.6-1.0($ Jago et al., 1995) & 0.8 \\
\hline$\alpha_{\mathrm{L}}(\mathrm{m})$ & $1-2($ Kelkar et al., 2006$)$ & 1 \\
\hline $\mathrm{D}_{\mathrm{L}}\left(\mathrm{m}^{2} / \mathrm{d}\right)$ & $0.6-1.2\left(\right.$ calculated using $\left.\mathrm{DL}=\alpha_{\mathrm{L}} \mathrm{V}+\mathrm{D}^{*}\right)$ & 0.8 \\
\hline $\mathrm{D}^{*}\left(\mathrm{~m}^{2} / \mathrm{d}\right)$ & $3 \times 10^{-9}$ & $3 \times 10-9$ \\
\hline
\end{tabular}


The analysis performed on the water quality data in Table 46 using the enhanced PHREEQC model indicates that the GW-923 water is supersaturated with Cinnabar (SI = 5.9). In other words, it supports the occurrence of deposited Cinnabar mineral at that location. This also indicates the potential that the dissolved Cinnabar can be released and become a source of $\mathrm{Hg}$. The analysis also suggests that GW-363 and GW-639 waters are supersaturated with Gibbsite and $\mathrm{Fe}(\mathrm{OH})_{3}$. In order to better understand the transport of $\mathrm{Hg}$ in the site, a number of simulations were made, which are explained next. These simulations were based on the following general assumptions:

1) Groundwater from well 916 (Table 45) flows through the $\mathrm{Ca}-\mathrm{Mg}-\mathrm{HCO}_{3}$ background water type to well 639 over $975 \mathrm{~m}$ of travel distance.

2) The transport model in PHREEQC is divided in to 50 cells each of $20 \mathrm{~m}$ length.

3) The flow parameters in Table 46 are used for the simulation.

4) The dissolution of Cinnabar at GW-923 constantly releases $120 \mathrm{ng} / \mathrm{L}$ of dissolved Hg.

5) A CEC of $130 \mathrm{mmol} / \mathrm{L}$ is the ion exchange capacity of the bedrock applied for all the cells to assess ion-exchange.

6) The $\mathrm{Fe}(\mathrm{OH})_{3}$ and Gibbsite minerals are present at wells 363 and 639 (cells 34 , 35 and 49), which is indicated by the SI of the minerals in Table 45. These minerals are considered as the sorbents that can complex with $\mathrm{Hg}$ by the role of surface complexation. 
7) Simulation scenarios were conducted for 1) $1 \mathrm{~g}$ of the sorbents: $\mathrm{Fe}(\mathrm{HO})_{3}$, Gibbsite, and Kaolinite in cells 34, 35 and 49 and 2) different combinations of sorbents $\mathrm{Fe}(\mathrm{HO})_{3}$ and Gibbsite in cells 34,35 and 49.

A schematic of the $\mathrm{Hg}$ transport situation for this site is shown in Figure 54.
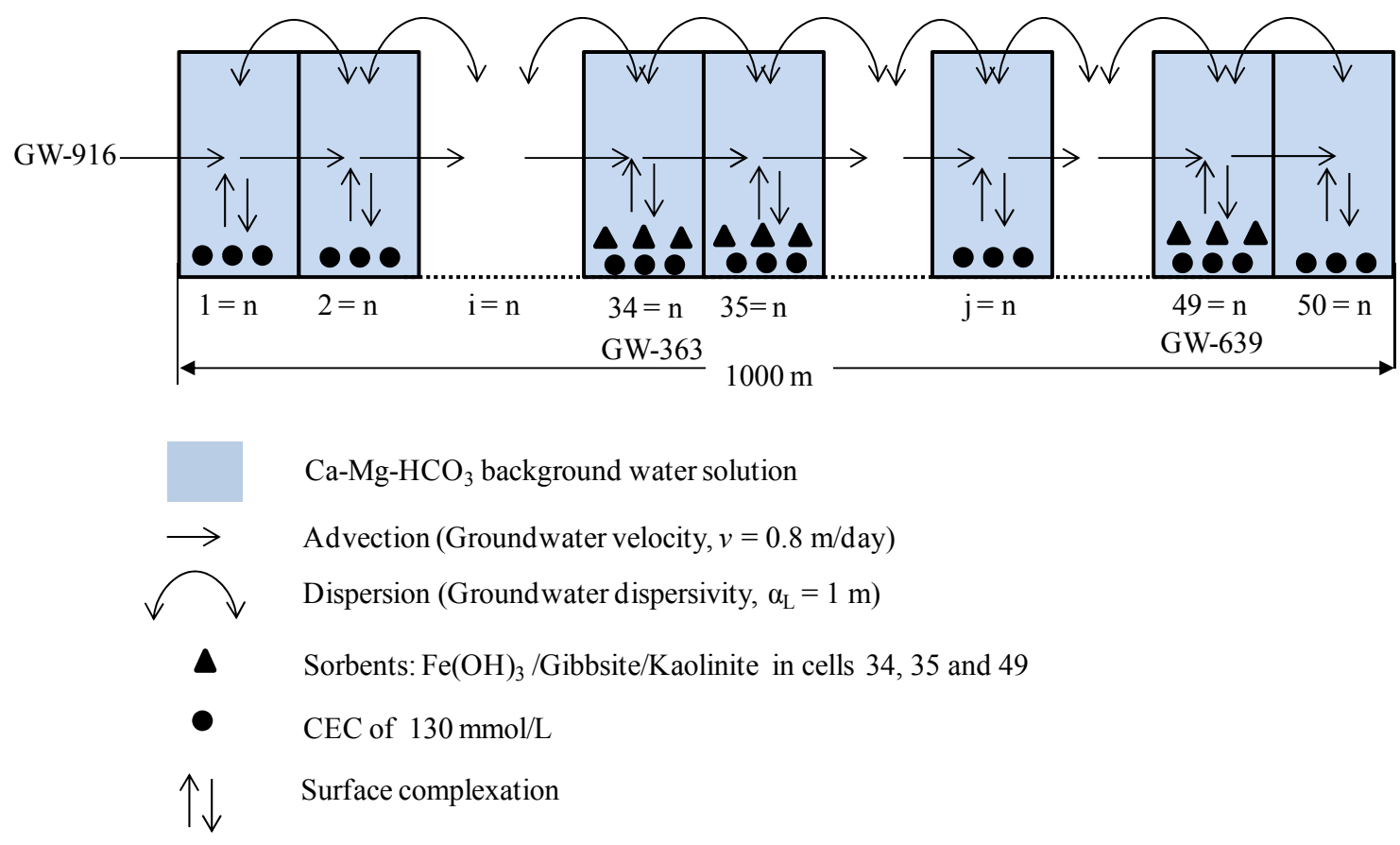

Figure $54 \mathrm{Hg}$ transport model for Bear Creek Valley

6.2.1.1 Scenario 1: $\mathrm{Hg}$ transport with $1 \mathrm{~g} / 1$ of different sorbents for surface complexation reaction

The results of the $\mathrm{Hg}$ transport simulations based on the assumptions mentioned earlier are shown in Figure 55. Without the presence of sorbent, the dissolved total $\mathrm{Hg}$ (THg) profile matches the concentration at wells GW-916 and 923. However, the measurements taken downstream (GW-363 and 639) are significantly lower than that 
predicted by the model (assuming no sorbent was present). It can be inferred that sorbents were present downstream which reduces the concentration of $\mathrm{Hg}$ in water. This simulation confirms, to a certain extent (based on the good correlation obtained at the first two wells), the "validity" of the assumptions 4 and 5 (CEC value and rate of $\mathrm{Hg}$ release due to the dissolution of Cinnabar).

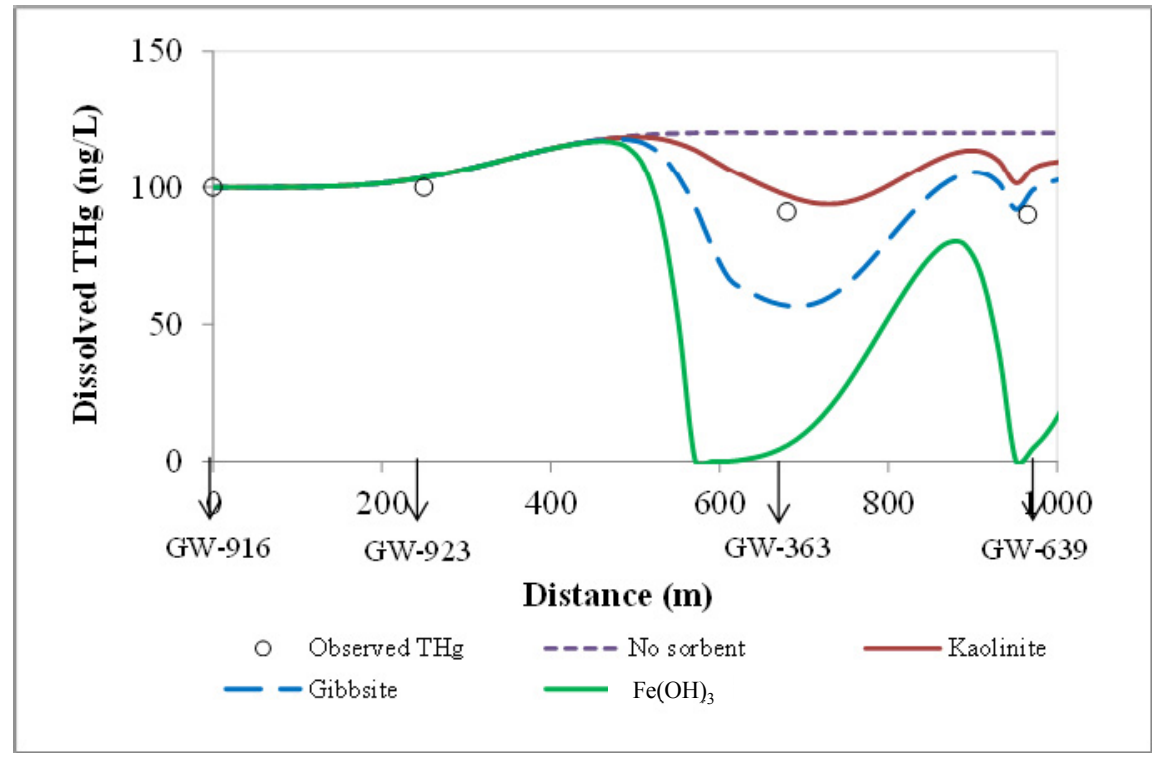

Figure 55 Dissolved THg transported in the presence of three different sorbents, individually present in cells 34,35 and 49, at Bear Creek Valley

It should also be noted that when the sorbents were added, strong surface complexation occurred between dissolved $\mathrm{THg}$ and $\mathrm{Fe}(\mathrm{OH})_{3}$ and led to a reduction in concentration of $\mathrm{Hg}$ at GW-363 and GW-639. With $1 \mathrm{~g}$ of Fe(OH) 3 at cells 34, 35 and 49, the dissolved THg appears to be underestimated compared to the observed data. Applying $1 \mathrm{~g}$ of Gibbsite into those cells also indicates an underestimation of THg at GW-363, while over estimation is obtained at location of GW-639. With $1 \mathrm{~g}$ of Kaolinite in the 
same cells, the model shows a slight overestimation of THg at both wells GW-363 and GW-639.

A sensitivity study was also conducted for CEC. However, CEC did not show any significant effect on $\mathrm{THg}$ concentration. This seems to be because of the low exchange constant $(\log \mathrm{K})$ for $\mathrm{Hg}$ at low CEC values.

6.2.1.2 Scenario 2: Hg transport using a combination of sorbents for surface complexation reaction

This scenario was conducted to determine the optimum amount of sorbents present at GW-363 and 639 that will give a good correlation between the simulation and observed data. The optimization was achieved by performing several simulations with different amounts and combinations of sorbents. The optimum amount of sorbents was found to be 4 and $5 \mathrm{mg}$ of Gibbsite and $\mathrm{Fe}(\mathrm{OH})_{3}$, respectively, at GW-363 and $1 \mathrm{~g}$ and 5 mg of Gibbsite and $\mathrm{Fe}(\mathrm{OH})_{3}$, respectively, at GW-639. The results are shown in Table 47 and Figure 56.

Table 47 Optimum amount of sorbents at GW-363 and GW-639

\begin{tabular}{|ccc|}
\hline Sorbents & Cells 34-35(GW-363) & Cell 49 (GW-639) \\
\hline Gibbsite & $4 \mathrm{mg}$ & $1 \mathrm{~g}$ \\
\hline $\mathrm{Fe}(\mathrm{OH})_{3}$ & $5 \mathrm{mg}$ & $5 \mathrm{mg}$ \\
\hline
\end{tabular}




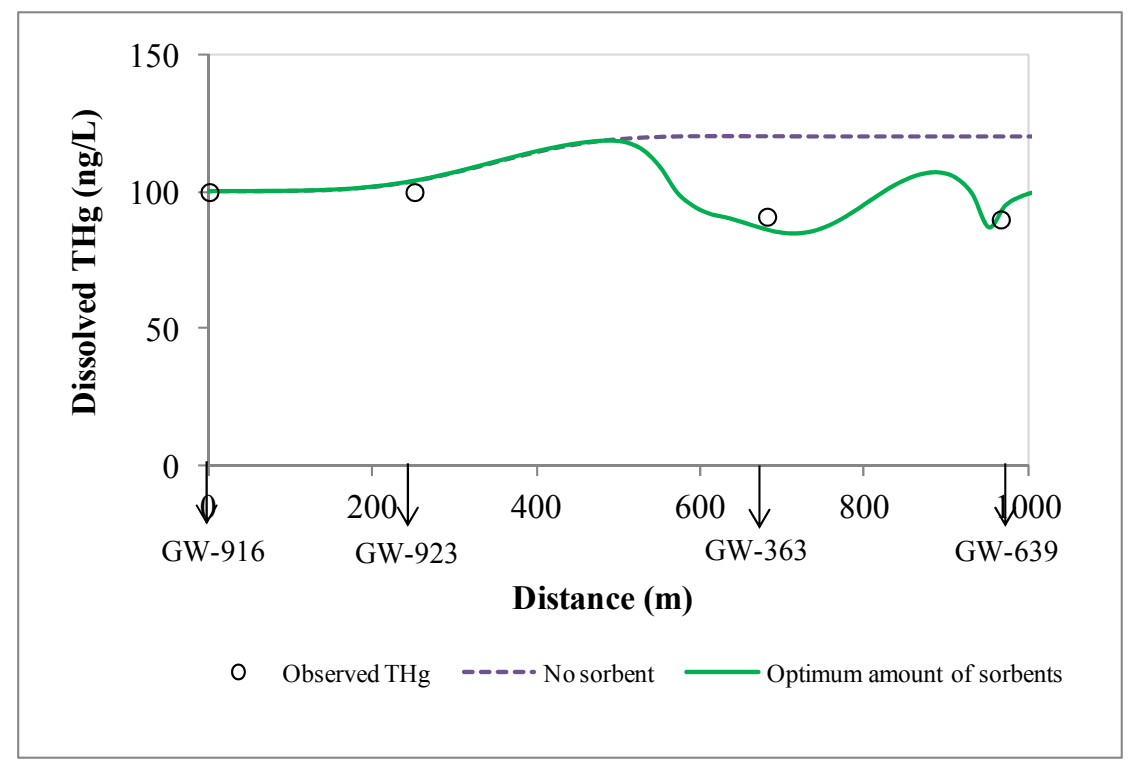

Figure 56 Dissolved THg transported in the presence of two different sorbents, simultaneously present in cells 34,35 and 49, at Bear Creek Valley

Figure 56 shows that $\mathrm{THg}$ concentration obtained for the enhanced model simulation, using optimized amounts of sorbents for surface complexation. The result provides a good match with observed data. With the optimum amount of sorbents, the enhanced model was then used to estimate the distribution of Hg-species along the main flow path. The comparison of $\mathrm{Hg}$-species and $\mathrm{pH}$ profiles between the model results and observed data is shown in Figure 57.

It can be observed in Figure 57 that the model results match well with the observed data for most of the $\mathrm{Hg}$-species and the $\mathrm{pH}$ profile along the flow distance. The difference in concentration between the $\mathrm{Hg}$-species at each location is related to the $\mathrm{pH}$ of that location. At GW-923 where $\mathrm{pH}$ is neutral, $\mathrm{HgCl}_{2}$ is dominant, while the second dominant species is $\mathrm{HgClOH}$. With an increase in $\mathrm{pH}, \mathrm{HgCl}_{2}$ decreases. $\mathrm{HgClOH}$ shows its peak at $\mathrm{pH} 7.5$ at a distance of $400 \mathrm{~m} . \mathrm{HgCl}_{2}$ and $\mathrm{HgClOH}$ become relatively low at a 
farther distance when $\mathrm{pH}$ is greater than 7.5, which favors the occurrence of $\mathrm{Hg}(\mathrm{OH})_{2}$. $\mathrm{Hg}(\mathrm{OH})_{2}$ is the dominant species at GW-363 and 639.

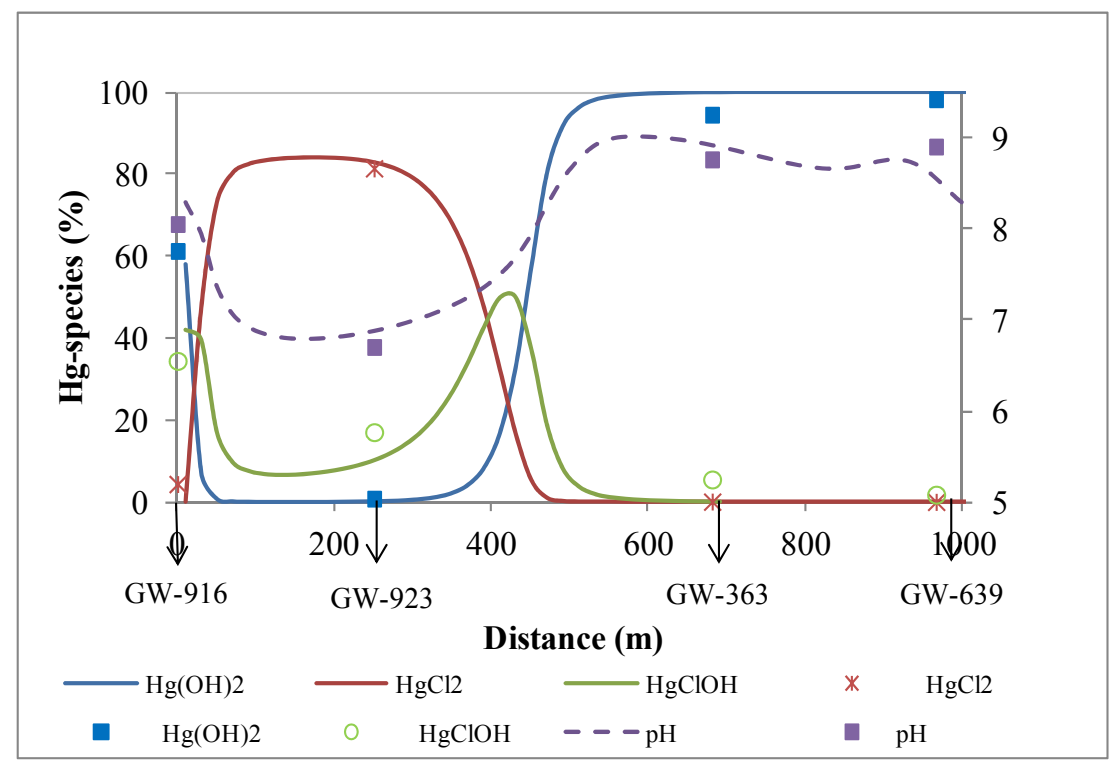

Figure 57 Comparison of Hg-species and $\mathrm{pH}$ profiles along the flow distance between the model results and observed data. The points represent observed data and the lines represent model results

The model results show a peak of $\mathrm{HgClOH}$ species at $400 \mathrm{~m}$. This is consistent with the $\mathrm{pH}$ value (7.5) observed at this location $(\mathrm{HgClOH}$ dominates other $\mathrm{Hg}$ species at $\mathrm{pH}=7.5)$

\subsection{ORR Test-Bed Simulation - Surface Water Transport Mode}

This section presents the $\mathrm{Hg}$ transport study in EFPC where the Hg contamination in the creek water has been of concern since the 1980s. The major cause of this contamination was the accidental spills and discharges of $128,000 \pm 35,000 \mathrm{~kg} \mathrm{Hg}$ to the EFPC that occurred during the period of operation of the Y-12 plant (1950-1963) (Brooks 
and Southworth, 2011; Dong et al. 2010). Many attempts have been made since then to reduce the mercury concentration in EFPC. In 2011, an 85\% decrease from $2000 \mathrm{ng} / \mathrm{L}$ in 1980s was reported (Brooks and Southworth, 2011). However, throughout of EFPC, the $\mathrm{Hg}$ concentration was reported to be in excess of the $0.051 \mu \mathrm{g} / \mathrm{L}$ criterion (TDEC, 2008). The Hg concentrations obtained from the monitoring stations were $0.5 \mu \mathrm{g} / \mathrm{L}$ at EFK 23.4 located at the EFPC headwater, $0.3 \mu \mathrm{g} / \mathrm{L}$ at EFK $18.3(\sim 5 \mathrm{~km}$ downstream from EFPC headwater), and $0.25 \mu \mathrm{g} / \mathrm{L}$ at EFK 13.8 ( $\sim 10 \mathrm{~km}$ downstream from EFPC headwater) (Brooks and Southworth, 2011; TDEC, 2008). EFK is an operational code used to identify and name monitoring stations along the creek.

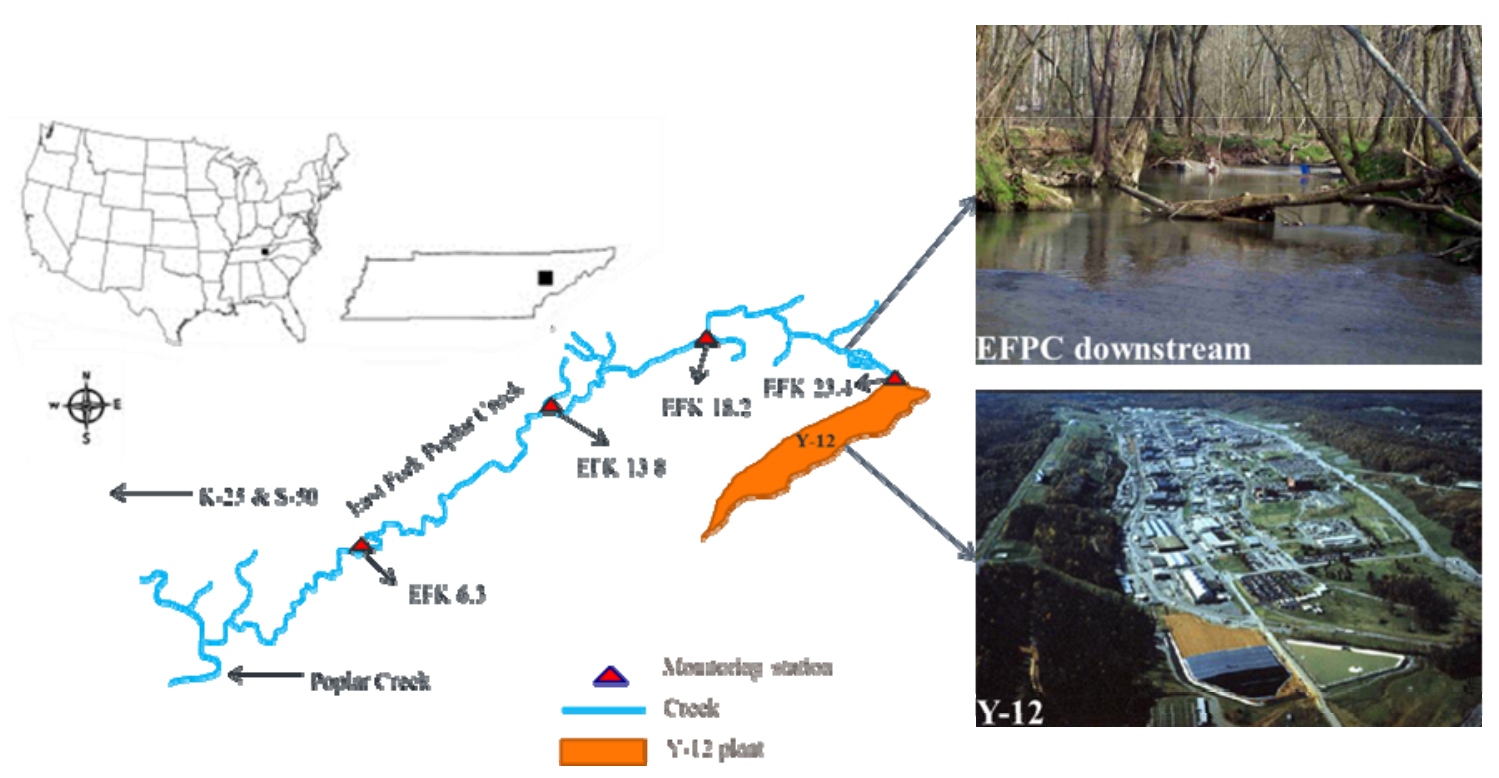

Figure 58 EFPC and Y-12 map (modified after www.esd.ornl.gov) 


\subsubsection{Hg in Surface Water Transport: Hg Reduction Load to EFPC}

In order to achieve the concentration criterion, $\mathrm{Hg}$ daily load reduction strategy was used (Brooks and Southworth, 2011; Loar et al., 2011). The loading of total Hg to EFPC was estimated to exceed $100 \mathrm{~g}$ /day in 1985 . Hg loading decreased to $15 \mathrm{~g} /$ day by 1993 (Brooks and Southworth, 2011; Loar et al., 2011) and 1-10 g/day by 2007 (TDEC, 2008). Therefore, in this section the simulations were conducted to test how long the $\mathrm{Hg}$ concentration in EFPC may take to reduce to the concentration criterion of $0.051 \mu \mathrm{g} / \mathrm{L}$ with respect to a range of $\mathrm{Hg}$ loadings $(2.5 \mathrm{~g} /$ day, $1.5 \mathrm{~g} /$ day and $0.5 \mathrm{~g} / \mathrm{day})$. The PHAST integrated model and the developed PHREEQC database were used for the simulations. The EFPC is approximately 5-9 $\mathrm{m}$ wide and $30 \mathrm{~km}$ long (Loar et al., 2011) (Figure 58). However, the modeling domain in this study was a $5 \mathrm{~m}$ x $10 \mathrm{~km}$ (width $\mathrm{x}$ length) stretch, which covers the stations EFK 23.4, EFK 18.2, and EFK 13.8. The modeling domain was selected based on the availability of water quality data. The $\mathrm{Hg}$ transport was simulated with the following assumptions: 1) The head boundary (water level) at location EFK 23.4 was $1 \mathrm{~m}$ and 2) the flow occurs only in forward direction (from EFK 23.4 to EFK 13.8). The water quality data, at different locations (EFK 23.4, EFK 18.2, EFK 13.8), were collected from previous studies (Loar et al., 2011; Dong et al., 2010; Brooks and Southworth, 2011) and used in the model (Table 48). The surface complexation $[1 \mathrm{mg} / \mathrm{L}$ of $\left.\mathrm{Fe}(\mathrm{OH})_{3}\right]$ and ion-exchange $(\mathrm{CEC}=0.01 \mathrm{~mol} / \mathrm{L})$ properties were applied to all the model domains. The flow parameters collected from Loar et al. (2011) and Vasquez (2008) studies were used in the model (Table 49). 
Table 48 EFPC surface water quality at different monitoring stations (ion concentrations in mg/L) (Loar et al., 2011; Dong et al., 2010; Brooks and Southworth, 2011)

\begin{tabular}{|c|c|c|c|}
\hline Parameters & EFK 23.4 & $\begin{array}{l}\text { Stations } \\
\text { EFK 18.3 }\end{array}$ & EFK 13.8 \\
\hline Temperature, ${ }^{\circ} \mathrm{C}$ & 25 & 25 & 25 \\
\hline pe & 3.81 & 3.81 & 3.81 \\
\hline $\mathrm{pH}$ & $7.0-9.2$ & $7-9.2$ & $7-9.2$ \\
\hline Total $\mathrm{Ca}$ & 44 & 37.4 & 30.8 \\
\hline Total Mg & 11.66 & 11.29 & 10.93 \\
\hline Total $\mathrm{Na}$ & 25.3 & 21.505 & 17.71 \\
\hline Total K & 3.51 & 2.73 & 1.95 \\
\hline Total Fe & 0.0015 & 0.0015 & 0.0015 \\
\hline Total Cl & 23.01 & 15.399 & 7.788 \\
\hline Total $\mathrm{HCO}_{3}$ & 128.1 & 125.05 & 122 \\
\hline Total $\mathrm{NO}_{3}$ & 17.36 & 11.78 & 6.2 \\
\hline Total $\mathrm{PO}_{4}$ & 1.1388 & 0.6880 & 0.23 \\
\hline Total Zn & 0.0169 & 0.0137 & 0.0105 \\
\hline Total $\mathrm{Cu}$ & 0.0017 & 0.0013 & 0.0008 \\
\hline Total Cd & 0.0001 & 0.003 & 0.0058 \\
\hline Total Pb & 0.0002 & 0.0002 & 0.0001 \\
\hline Total Hg & 0.0005 & 0.0003 & 0.00025 \\
\hline $\mathrm{CEC}(\mathrm{mol} / \mathrm{L})$ & 0.01 & 0.01 & 0.01 \\
\hline Sorbent $\left[\mathrm{mg}\right.$ of $\left.(\mathrm{FeOH})_{3} / \mathrm{L}\right]$ & 1 & 1 & 1 \\
\hline
\end{tabular}


Table 49 Transport parameters used for $\mathrm{Hg}$ transport study in EFPC

\begin{tabular}{|c|c|}
\hline Parameters & Values \\
\hline Model Domain & $10 \mathrm{~km} \times 5 \mathrm{~m}$ \\
\hline Velocity, m/d & 12,960 (Vasquez, 2008; Loar et al., 2011) \\
\hline Loading rate, $\mathrm{cfs}(\mathrm{cms})$ & 11 (0.31) (Vasquez, 2008; Loar et al., 2011) \\
\hline Dispersivity, $\mathrm{m}$ & 6 (Loar et al., 2011) \\
\hline Diffusivity, $\mathrm{m}^{2} / \mathrm{s}$ & $1 \times 10^{-9}$ (Loar et al., 2011) \\
\hline Number of Grid in X axel & 100 \\
\hline Number of Grid in Y axel & 5 \\
\hline Number of Grid in Y axel & 1 \\
\hline Grid size & $0.1 \mathrm{~km} \times 1 \mathrm{~m}$ \\
\hline Grid for EFK 23.4 station $\left(X_{1}, Y_{1}, Z_{1}: X_{2}, Y_{2}, Z_{2}\right)$ & $\begin{array}{c}0,0,0: 50,5,1 \text { it is associated with water } \\
\text { quality from station EFK } 23.4\end{array}$ \\
\hline Grid for EFK 18.3 station $\left(X_{1}, Y_{1}, Z_{1}: X_{2}, Y_{2}, Z_{2}\right)$ & $\begin{array}{c}50,0,0,: 70,5,1 \text { it is associated with water } \\
\text { quality from station EFK } 18.3\end{array}$ \\
\hline Grid for EFK 13.8 station $\left(X_{1}, Y_{1}, Z_{1}: X_{2}, Y_{2}, Z_{2}\right)$ & $\begin{array}{l}70,0,0,: 100,5,1 \text { it is associated with } \\
\text { water quality from station EFK } 13.8\end{array}$ \\
\hline Initial $\mathrm{Hg}$ concentration at EFK 23.4 station, $\mu \mathrm{g} / \mathrm{L}$ & 0.5 \\
\hline Initial $\mathrm{Hg}$ concentration at EFK 18.3 station, $\mu \mathrm{g} / \mathrm{L}$ & 0.3 \\
\hline Initial $\mathrm{Hg}$ concentration at EFK 13.8 station, $\mu \mathrm{g} / \mathrm{L}$ & 0.2 \\
\hline Ion-exchange: CEC $1 \mathrm{mmol} / \mathrm{L}$ & All domain \\
\hline Sorbent: $1 \mathrm{mg} \mathrm{Fe}(\mathrm{OH})_{3} / \mathrm{L}$ & All domain \\
\hline
\end{tabular}

The transport model employed an EFPC average hydraulic retention time of 0.25 day. Figure 59 shows the model domain and the initial concentrations of $\mathrm{Hg}$ in EFPC at different locations. The $\mathrm{Hg}$ transport simulations were calculated at 3 different $\mathrm{Hg}$ loading rates $(2.5 \mathrm{~g} /$ day, $1.5 \mathrm{~g} /$ day and $0.5 \mathrm{~g} /$ day $)$. These rates were used to define a range of possible $\mathrm{Hg}$ pollution prevention strategies. 


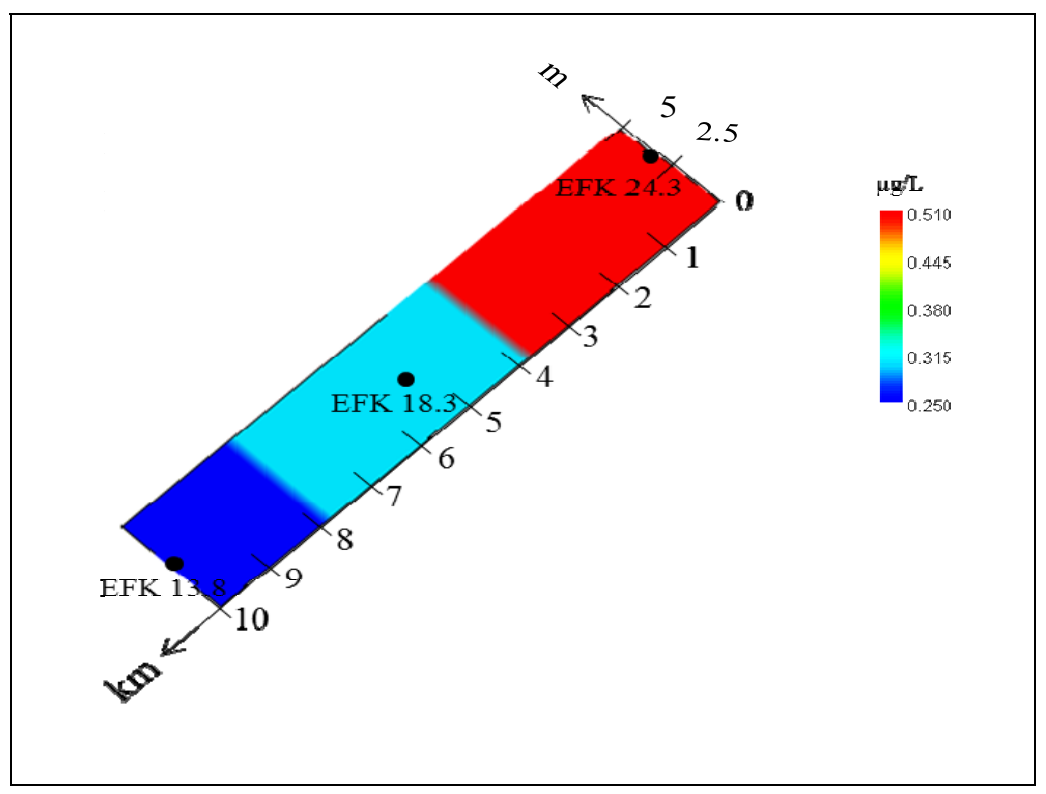

Figure 59 Initial concentration of $\mathrm{Hg}$ in EFPC water at different monitoring stations

\subsubsection{Scenario 1: Hg loading of $2.5 \mathrm{~g} /$ day at the source}

Simulation scenario 1 was made with a $2.5 \mathrm{~g}$ /day of $\mathrm{Hg}$ loading at the source (EFK 24.3) in the EFPC. The simulation was conducted to predict the time that takes to reduce the $\mathrm{Hg}$ concentration in the creek to meet the concentration criterion of 0.051 $\mu \mathrm{g} / \mathrm{L}$. The simulation was started with initial background $\mathrm{Hg}$ concentrations in the creek as $0.5 \mu \mathrm{g} / \mathrm{L}, 0.3 \mu \mathrm{g} / \mathrm{L}$, and $0.2 \mu \mathrm{g} / \mathrm{L}$ at EFK $23.4,18.3$, and 13.8 , respectively. 

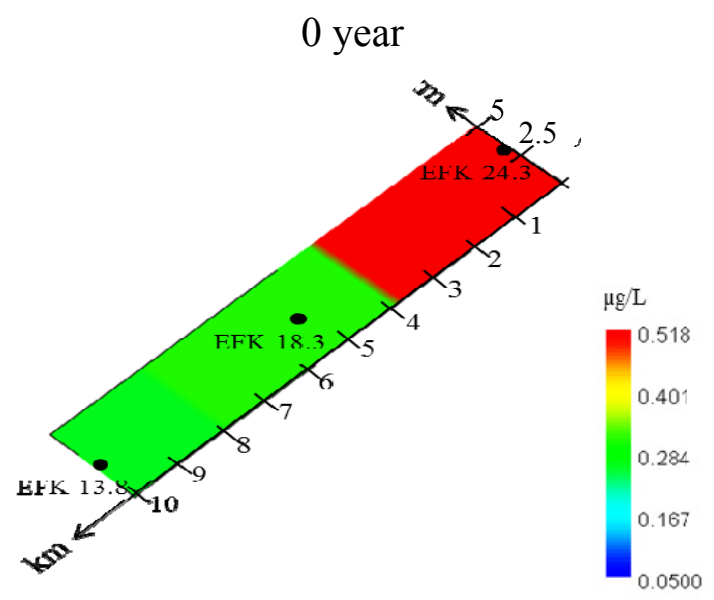

15 years
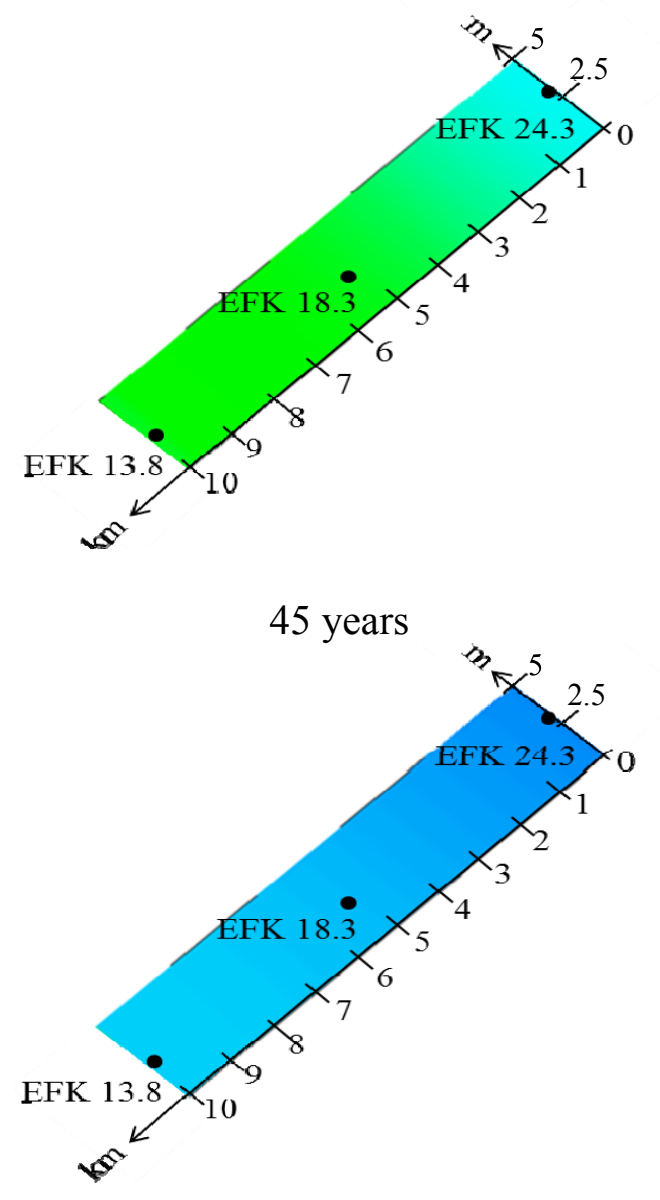
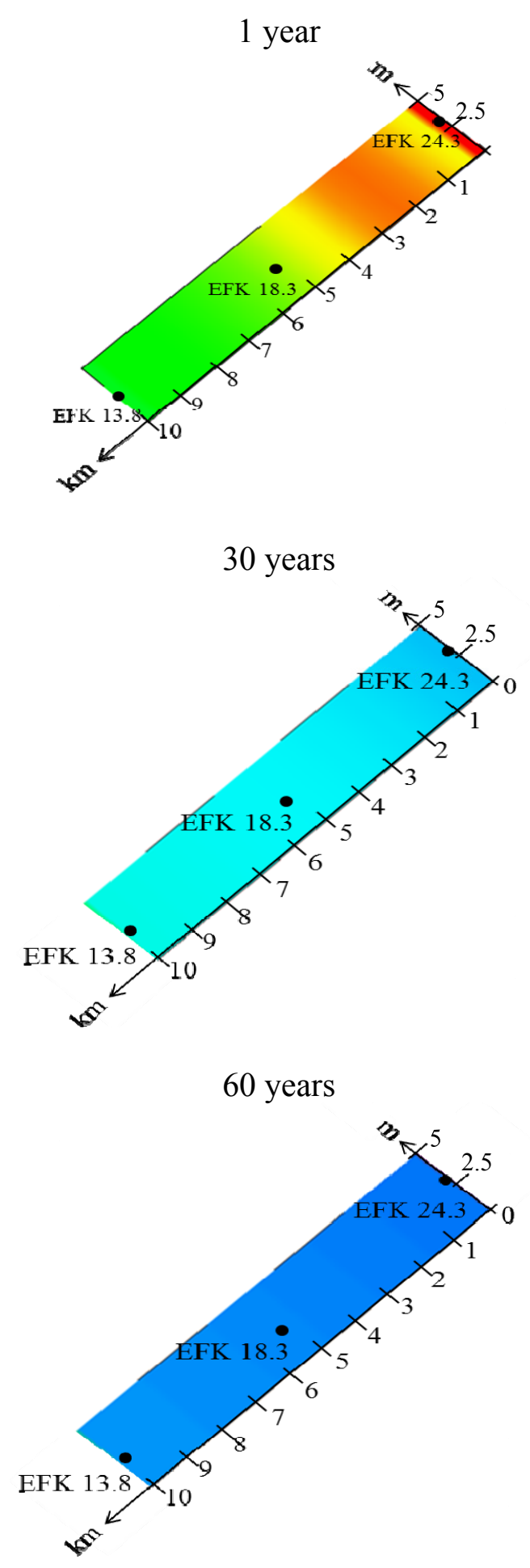

Figure 60 Transport of dissolved $\mathrm{Hg}$ in EFPC water with loading rate of $2.5 \mathrm{~g}$ /day (from EFK 24.3 to EFK 13.8) 
In Figure 60, at a $\mathrm{Hg}$ mass loading of $2.5 \mathrm{~g} /$ day, (flow rate is $11 \mathrm{cfs}$, $\mathrm{Hg}$ concentration is $9.3 \times 10^{-5} \mathrm{mg} / \mathrm{L}$ ), the simulation shows that the concentration at EFK 24.3 becomes lower than the downstream concentrations (EFK 18.3 and 13.8) by year 13 (not shown in the Figure). By year 15, the total dissolved Hg concentration at EFK 24.3 decreased approximately to $0.15 \mu \mathrm{g} / \mathrm{L}$ (from an initial concentration of $0.5 \mu \mathrm{g} / \mathrm{L}$ ). The concentrations at EFK 18.3 and EFK 13.8 did not show any significant change. However, a reduction in total dissolved $\mathrm{Hg}$ concentrations at EFK 18.3 and 13.8 are observed in year $30(0.15 \mu \mathrm{g} / \mathrm{L})$. Hg concentrations of less than $0.1 \mu \mathrm{g} / \mathrm{L}$ for the entire model domain are reached by year 45 . These are $0.09,0.09$ and $0.1 \mu \mathrm{g} / \mathrm{L}$ at EFK 24.3, 18.3, and 13.8, respectively.

It also can be seen in Figure 61 that the total dissolved Hg concentration in the EFPC shows big reduction during years 10 and $25(\sim 100 \%$ reduction at EFK 24.3 and $\sim 200 \%$ reductions, at EFK 18.3 and 13.8). However, the reduction slows down in the later years; in fact, reduction rates between years 35,45 , and 60 are very small. The result shows that the total dissolved $\mathrm{Hg}$ reaches in a constant concentration of $0.08 \mu \mathrm{g} / \mathrm{L}$ by year 60. The model result also suggests that, with $2.5 \mathrm{~g} /$ day of $\mathrm{Hg}$ mass loading to the EFPC, the $\mathrm{Hg}$ concentrations will not meet the criteria of $0.051 \mu \mathrm{g} / \mathrm{L}$. 


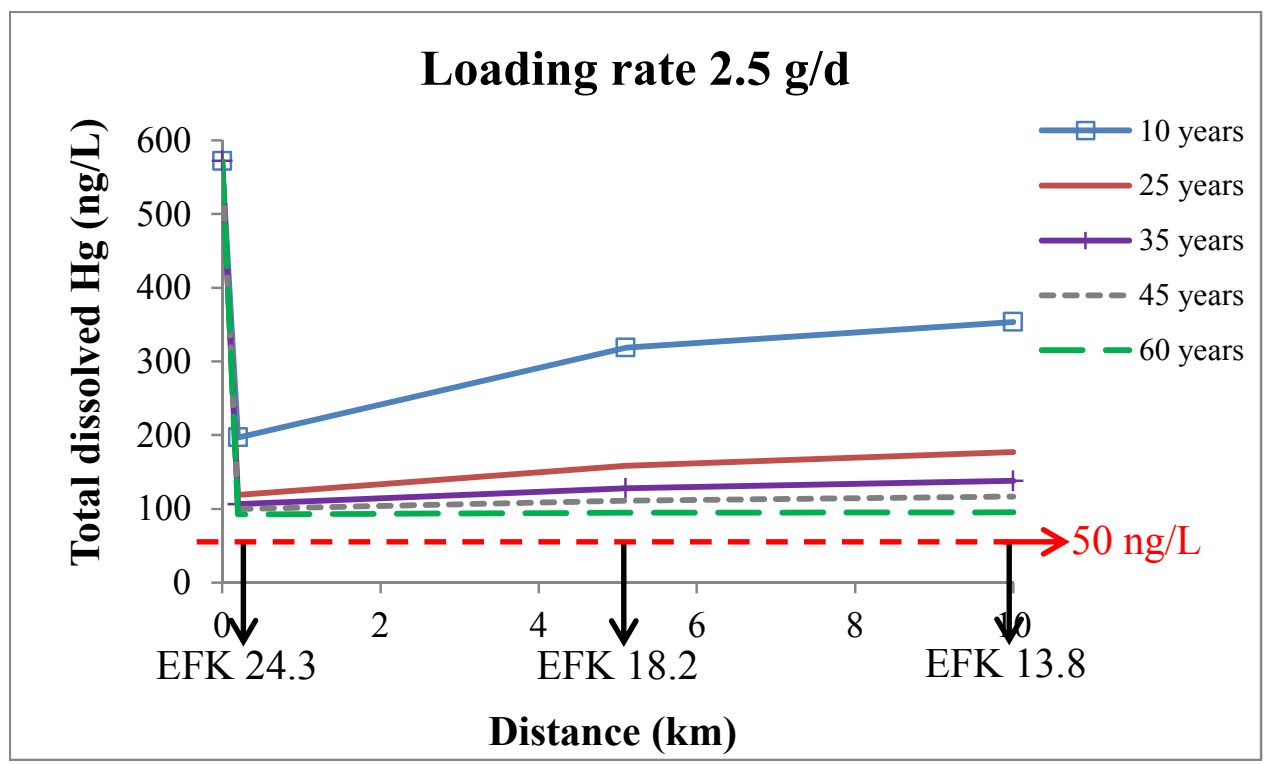

Figure 61 Total dissolved $\mathrm{Hg}$ concentration along the domain with $\mathrm{Hg}$ mass loading of $2.5 \mathrm{~g} /$ day

\subsubsection{Scenario 2: $\mathrm{Hg}$ loading of $1.5 \mathrm{~g} /$ day at source}

In simulation scenario 2, the $\mathrm{Hg}$ mass loading rate to the EFPC was reduced to 1.5 $\mathrm{g} /$ day. The simulation was conducted to predict the time that took to reduce the $\mathrm{Hg}$ concentration in the creek to criteria concentration of $0.051 \mu \mathrm{g} / \mathrm{L}$. The simulation started with initial background $\mathrm{Hg}$ concentrations in the creek of $0.5 \mu \mathrm{g} / \mathrm{L}, 0.3 \mu \mathrm{g} / \mathrm{L}$, and 0.2 $\mu \mathrm{g} / \mathrm{L}$ at EFK 23.4, 18.3, and 13.8, respectively.

The results from using a $\mathrm{Hg}$ mass loading to $1.5 \mathrm{~g}$ /day in the simulation (see Figure 62) showed that the dissolved Hg concentration at EFK 24.3 becomes lower than the downstream concentrations (EFK 18.3 and 13.8) by year 9 (not shown in the figure). By year 15, Hg concentrations at EFK 24.3 are predicted to be about $0.15 \mu \mathrm{g} / \mathrm{L}$ (from 0.5 $\mu \mathrm{g} / \mathrm{L})$, extending over a larger area compared to scenario $1\left(0.5 \mathrm{~km}^{2}\right.$ for Scenario 1 , and 1 $\mathrm{km}^{2}$ for scenario 2). Total dissolved Hg concentrations at EFK 18.3 and EFK 13.8 did not 
show a significant change after 15 years. However, the reduction in total dissolved $\mathrm{Hg}$ concentrations at EFK 18.3 and 13.8 is expected in year 25 to reach $0.15 \mu \mathrm{g} / \mathrm{L}$. Concentrations of less than $0.1 \mu \mathrm{g} / \mathrm{L}$ for the entire model domain are obtained by year 35 ; they are $0.06,0.07$ and $0.08 \mu \mathrm{g} / \mathrm{L}$ at EFK 24.3, 18.3, and 13.8, respectively. It can also be noted in Figure 63 that the total dissolved Hg concentration in the EFPC shows a big reduction during years 10,25 , and 35 ; the reduction percentage of $\mathrm{Hg}$ concentrations at all stations, between years 10 and 25 is in the range $100 \%-200 \%$; and is the same for years between years 25 and 35 is in the range is $25 \%-50 \%$. The reduction rate slows down in later years. The reduction rate between years 45 and 60 is very low with similar concentrations. Results show that the total dissolved $\mathrm{Hg}$ reaches its constant concentration of $0.051 \mu \mathrm{g} / \mathrm{L}$ (EFPC criterion) by year 45 . To summarize, with a $1.5 \mathrm{~g} /$ day of $\mathrm{Hg}$ loading to the EFPC, the total dissolved Hg concentration within the model domain is predicted to decrease, meeting the criteria of $0.051 \mu \mathrm{g} / \mathrm{L}$ by year 45 . 

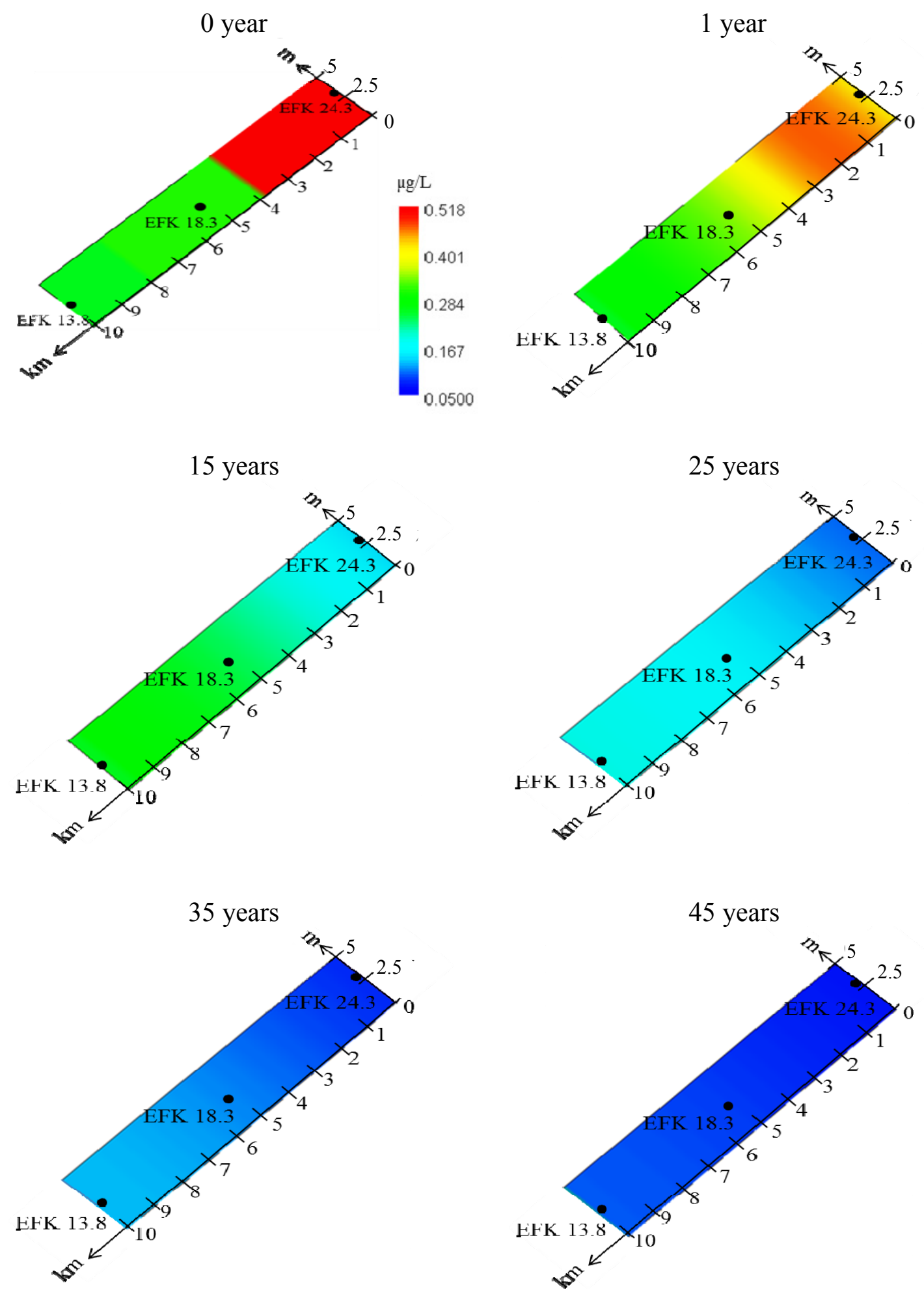

Figure 62 Transport of dissolved $\mathrm{Hg}$ in EFPC water with $\mathrm{Hg}$ mass loading of $1.5 \mathrm{~g}$ /day (from EFK 24.3 to EFK 13.8) 


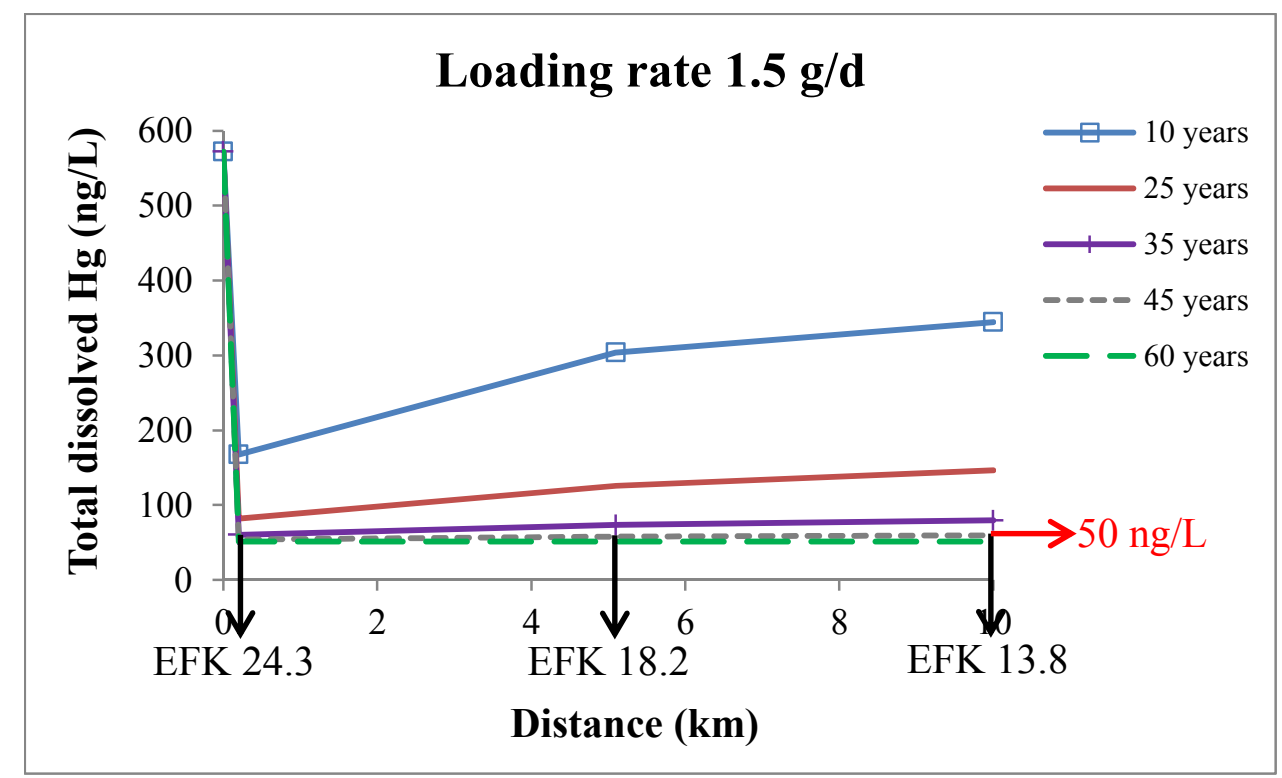

Figure 63 Total dissolved $\mathrm{Hg}$ concentration along the domain with $\mathrm{Hg}$ mass loading of $1.5 \mathrm{~g} /$ day

\subsubsection{Scenario 3: $\mathrm{Hg}$ loading of $0.5 \mathrm{~g} /$ day at the source}

In simulation scenario 3 , the $\mathrm{Hg}$ loading into the EFPC was set at $1.5 \mathrm{~g} /$ day. The simulation was conducted to predict the time that took to reduce the $\mathrm{Hg}$ concentration in the creek to criteria concentration $0.051 \mu \mathrm{g} / \mathrm{L}$. The simulation started with initial background $\mathrm{Hg}$ concentrations in the creek, which were of $0.5 \mu \mathrm{g} / \mathrm{L}, 0.3 \mu \mathrm{g} / \mathrm{L}$, and 0.2 $\mu \mathrm{g} / \mathrm{L}$ at EFK 23.4, 18.3, and 13.8, respectively. 
0 year
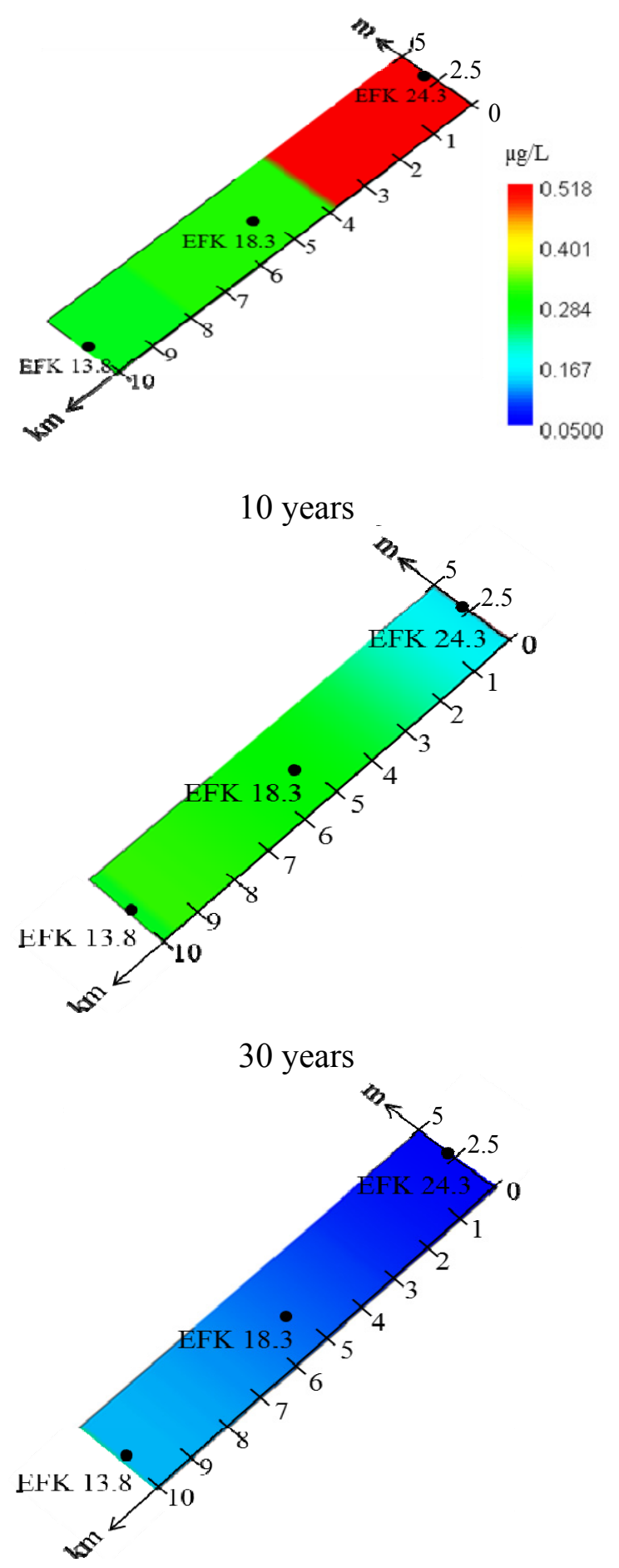

1 year
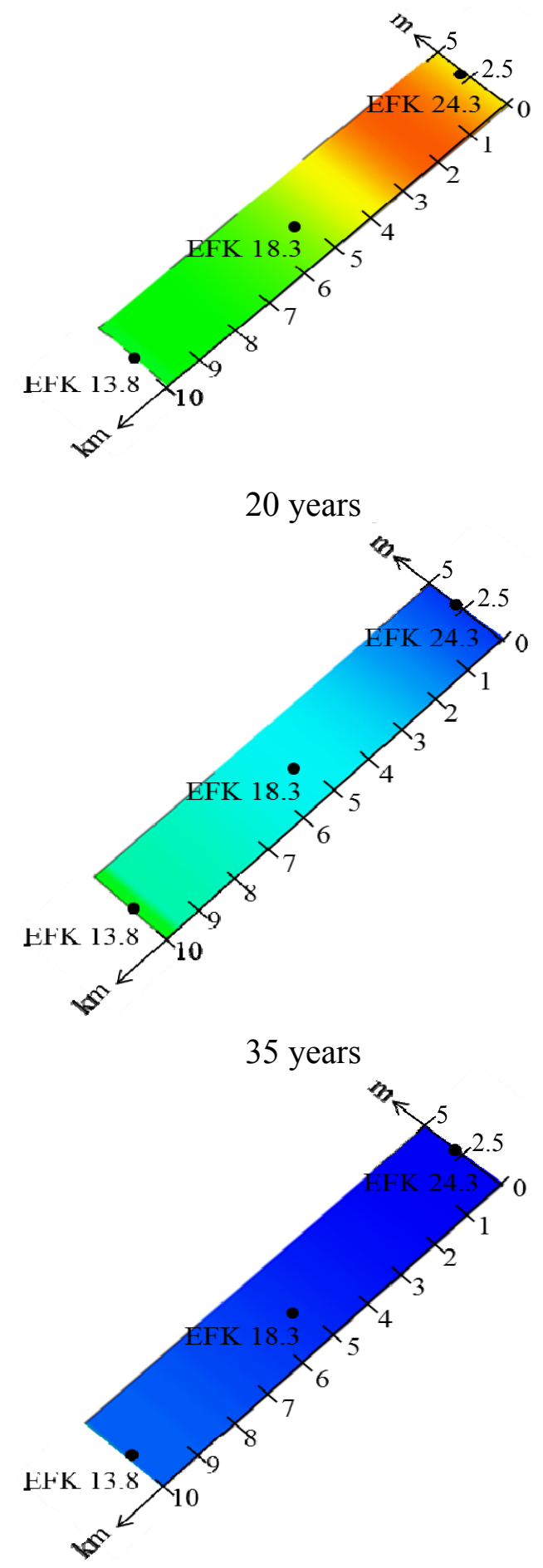

Figure 64 Transport of dissolved $\mathrm{Hg}$ in EFPC water with $\mathrm{Hg}$ mass loading of $0.5 \mathrm{~g} /$ day (from EFK 24.3 to EFK 13.8) 
In Figure 64, with a $\mathrm{Hg}$ mass loading of $0.5 \mathrm{~g} /$ day, the simulation result showed that the concentration at EFK 24.3 is diluted and is lower than the downstream concentrations (EFK 18.3 and 13.8) by year 7 (not shown in the figure). In year 10 the total dissolved $\mathrm{Hg}$ concentration at EFK 24.3 reaches about $0.15 \mu \mathrm{g} / \mathrm{L}$ (from $0.5 \mu \mathrm{g} / \mathrm{L}$ ), while the concentrations at EFK 18.3 and EFK 13.8 did not show any significant change with respect to the previous scenarios. However, the reduction in total dissolved $\mathrm{Hg}$ concentrations at EFK 18.3 and 13.8 reached $0.15 \mu \mathrm{g} / \mathrm{L}$ by year 20 . Concentrations less than $0.1 \mu \mathrm{g} / \mathrm{L}$ for the entire model domain were estimated by year 30 ; they were 0.06 , 0.07 , and $0.08 \mu \mathrm{g} / \mathrm{L}$ at EFK $24.3,18.3$, and 13.8 , respectively.

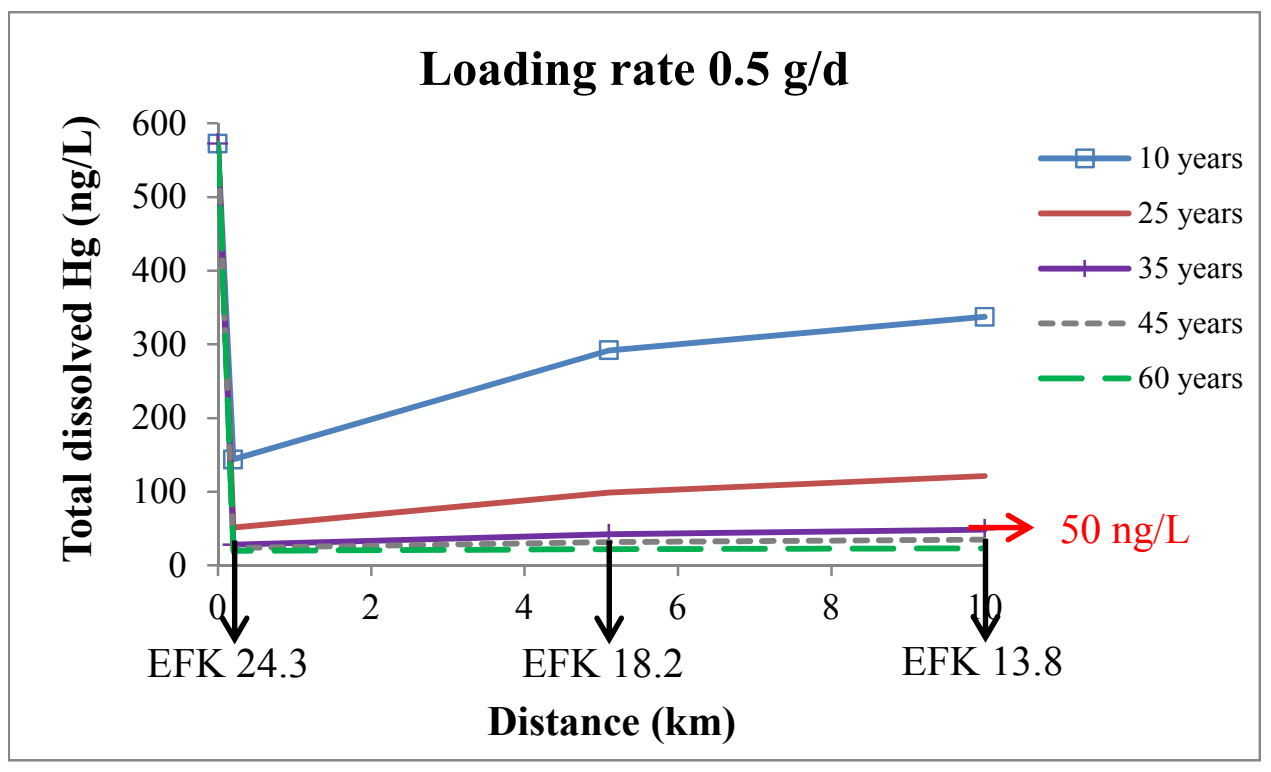

Figure 65 Total dissolved $\mathrm{Hg}$ concentration along the domain with $\mathrm{Hg}$ mass loading of $0.5 \mathrm{~g} /$ day

Figure 65 shows a big reduction of total dissolved $\mathrm{Hg}$ concentrations during years 10,25 , and 35 . The reduction percentage of $\mathrm{Hg}$ concentration at all stations, between 
years 10 and 25 is in the range $100 \%-230 \%$. The same reduction is predicted between 25 and 35 years, in the range of $25 \%$ to $70 \%$. The reduction rate reduces in later years. The reduction rates between years 35, 45 and 60 are low, with similar concentrations. Results also show that the total dissolved $\mathrm{Hg}$ can reach its constant concentration of $0.051 \mu \mathrm{g} / \mathrm{L}$ (EFPC criterion) by year 35. It can be summarized that with a $0.5 \mathrm{~g} /$ day of $\mathrm{Hg}$ loading into the EFPC, Hg concentrations within the model domain should decrease and meet the criterion of $0.051 \mu \mathrm{g} / \mathrm{L}$ by year 35 .

\subsection{ENP Test-Bed Simulations - Batch Mode}

For the ENP test-bed, the averaged values of surface water quality that were collected at ENP station P33 over ten years (2001-2011), were employed to assess Hg speciation using the enhanced PHREEQC model. The water quality data was obtained from the DBHYDRO website.The data showed wide variations in major cations and anions in the ENP, depending on the season. Although, various water chemical constituents were measured at this station, DOC data was not available. A vast number of studies indicated that, for ENP, DOC plays an important role on $\mathrm{Hg}$ fate. This is because of the abundance of existing of DOC in that setting and the strong binding constant of $\mathrm{Hg}$ with the Thiol ligand or the reduced sulfur ligand (RS-) present in DOC. Therefore, DOC and its $\mathrm{RS}^{-}$content must be considered and accounted for the $\mathrm{Hg}$-speciation study with ENP waters. Although, there was no data available for DOC at P33 station, the DOC concentrations in this study were calculated using a correlation between total suspended solid (TSS) and DOC using data obtained from Cai et al. (1999) (Figure 66). 


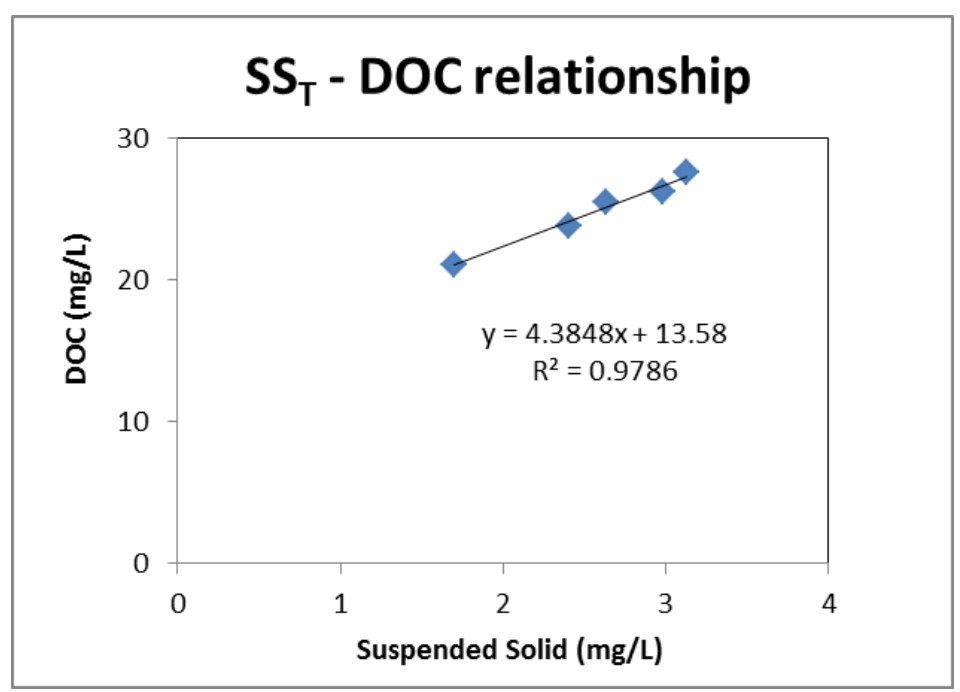

Figure 66 Relationship between the concentration of total suspended solid and DOM in ENP water (Cai et al., 1999)

The linear relationship between TSS and DOC, $\mathrm{Y}=4.38 \mathrm{X}+13.58$ where $\mathrm{Y}$ is DOC $(\mathrm{mg} / \mathrm{L})$ and $\mathrm{X}$ is TSS $(\mathrm{mg} / \mathrm{L})$, calculated using data in Cai et al. (1999) was used to estimate the DOC concentration at station P33. With this relationship, the calculated DOC at P33 ranged between $17-153 \mathrm{mg} / \mathrm{L}$. The average DOC concentration over 11 years was estimated to be $31 \mathrm{mg} / \mathrm{L}$. The average DOC value $(31 \mathrm{mg} / \mathrm{L})$ was consistent with the data reported by Reddy and Aiken (2001) and this value was used for this study. The ENP soil characteristic data (physical and chemical properties) are described in Appendix F.

The calculated DOC concentrations were then used to calculate the $\mathrm{RS}^{-}$content in DOC using an equation proposed by Dong et al. (2010). The calculated $\mathrm{RS}^{-}$ranged between $7.3-24.2 \times 10^{-5} \mathrm{mg} / \mathrm{L}$, with an average of $8.6 \times 10^{-5} \mathrm{mg} / \mathrm{L}$. The average values of surface water quality data of ENP, including calculated DOC and $\mathrm{RS}^{-}$, used in this study are shown in Table 50. 
Table 50 ENP surface water quality data at P33 station (during 2001-2011) (mg/L for concentration, ${ }^{\circ} \mathrm{C}$ for temperature) (DBHYDRO)

\begin{tabular}{|c|c|c|}
\hline Constituents & Range & Average Value \\
\hline Temperature & $9.0-30.7$ & 23.76 \\
\hline $\mathrm{pH}$ & $7.0-8.1$ & 7.47 \\
\hline DO & $0.8-9.1$ & 4.20 \\
\hline Alkalinity $\mathrm{HCO}_{3}^{-}$ & $53-277$ & 179.09 \\
\hline Total Ca & $39.8-118.3$ & 59.48 \\
\hline Total Cl & $14.3-108$ & 54.81 \\
\hline Total PO4 & $0.003-0.075$ & 0.0079 \\
\hline Nitrate $\mathrm{NO}_{3}^{-}$ & $0.005-0.127$ & 0.029 \\
\hline Nitrite $\mathrm{NO}_{2}^{-}$ & $0.002-0.011$ & 0.0035 \\
\hline Total K & $0.8-5.3$ & 3.12 \\
\hline Total Na & $10.3-66.6$ & 36.26 \\
\hline Total Mg & $3.9-17.1$ & 10.48 \\
\hline Total $\mathrm{SO}_{4}$ & $0.6-239$ & 9.26 \\
\hline Total SS & $1-32$ & 3.98 \\
\hline DOC & $17.96-153.89$ & 31.05 \\
\hline$* \mathrm{RS}^{-}$ & $7.3-24.2 \times 10^{-5}$ & $8.6 \times 10^{-5}$ \\
\hline Total Hg & $0.7-5.9 \times 10^{-6}$ & $2.023 \times 10^{-6}$ \\
\hline
\end{tabular}

* $\mathrm{RS}^{-}$represents the reduced sulfur was estimated by the equation proposed Dong et al., 2010) 


\subsubsection{Hg Speciation Distribution}

The ENP surface water quality data at P33 station, shown in Table 50, was used in the simulations. The speciation distribution of $\mathrm{Hg}$ in the ENP surface water is shown in Figure 67.

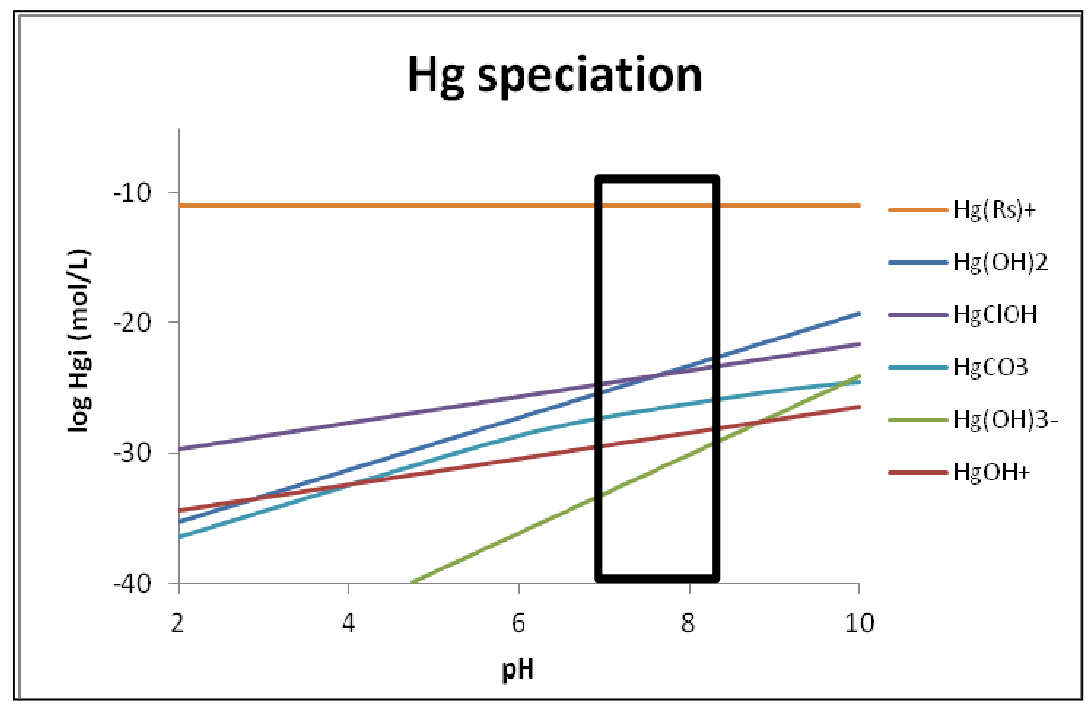

Figure $67 \mathrm{Hg}$ speciation in ENP surface water. The black box represents the $\mathrm{pH}$ range of ENP surface water ( $\mathrm{pH}$ 7.0-8.2)

It can be seen from Figure 67 that most of $\mathrm{Hg}(\mathrm{II})$ binds with the $\mathrm{RS}^{-}$content in the DOC. The $\mathrm{Hg}(\mathrm{RS})^{+}$species is at least ten orders of magnitude higher than other inorganic $\mathrm{Hg}$. This is because the reaction constant $(\log \mathrm{K}=28.5)$ of $\mathrm{Hg}(\mathrm{RS})^{+}$is higher than those of $\mathrm{Hg}$-inorganic $\left(\mathrm{Cl}^{-}, \mathrm{OH}^{-}, \mathrm{CO}_{3}{ }^{-}, \mathrm{SO}_{4}{ }^{2-}\right.$, etc. $)$ complexation.

\subsubsection{Sensitivity Analysis of Hg Species to Water Temperature and pH}

The sensitivity of ENP $\mathrm{Hg}$ species to water temperature and $\mathrm{pH}$ was studied for a range of temperatures $\left(5-35^{\circ} \mathrm{C}\right)$ and $\mathrm{pH}(2-10)$ (Figure 68). 

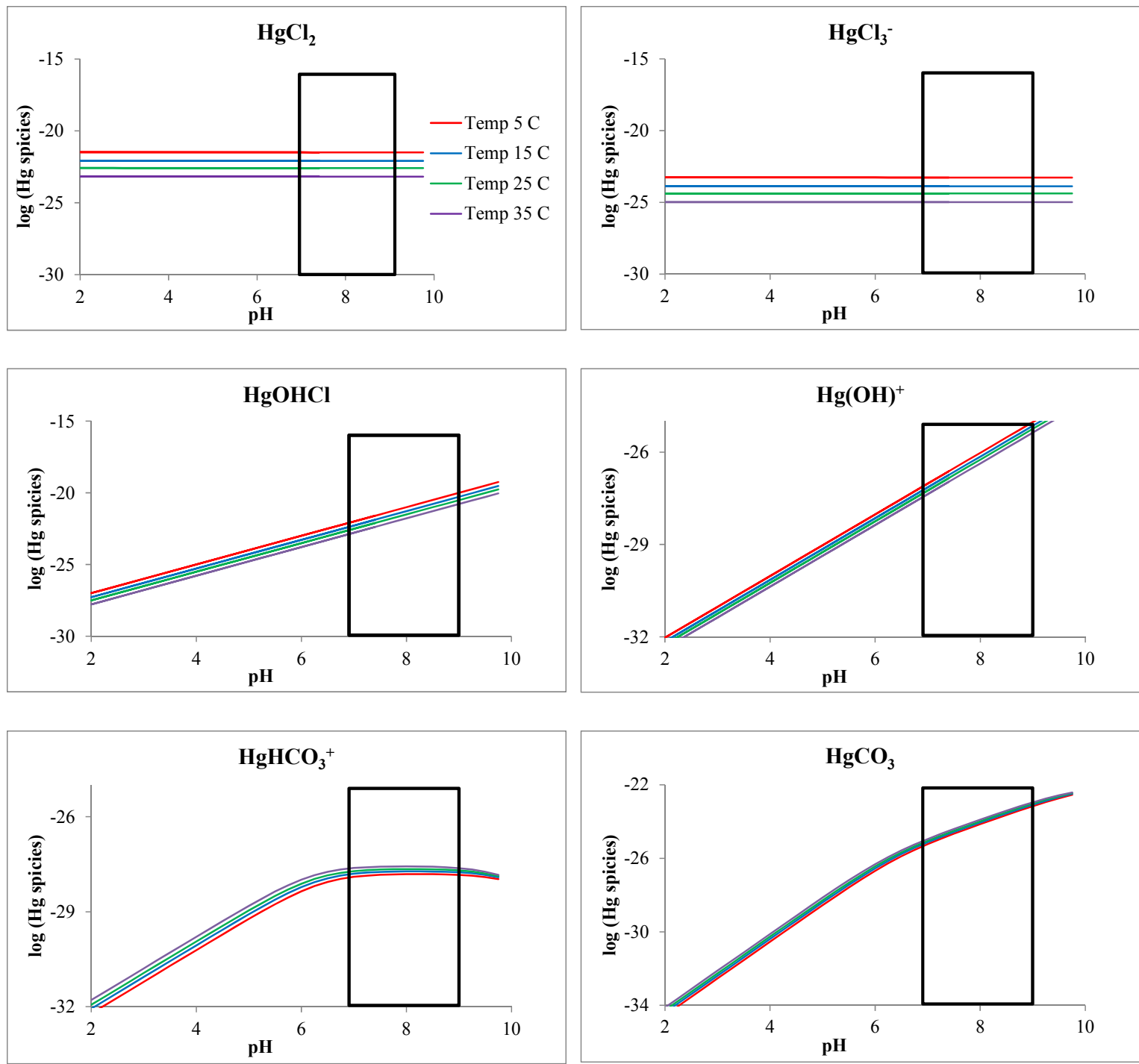

Figure $68 \mathrm{ENP} \mathrm{Hg}$ species sensitivity to temperature $\left(5-35^{\circ} \mathrm{C}\right)$ and $\mathrm{pH}(2-10)$. The black box shows the ENP water $\mathrm{pH}$ range

The formation of $\mathrm{Hg}-\mathrm{Cl}$ and $\mathrm{Hg}-\mathrm{OH}$ species decreases with increase in water temperature, while higher temperatures favor the formation of $\mathrm{Hg}_{-} \mathrm{CO}_{3}$ species (Figure 68). The water $\mathrm{pH}$ does not affect the formation of $\mathrm{Hg}-\mathrm{Cl}$ species; however, the concentration of $\mathrm{Hg}-\mathrm{OH}$ species shows a steady increase with water $\mathrm{pH}$. This is because higher $\mathrm{pH}$ promotes the formation of $\mathrm{OH}^{-}$ion. The concentration of $\mathrm{Hg}-\mathrm{CO}_{3}$ species 
increases sharply between $\mathrm{pH} 2-6$. The rate formation of $\mathrm{HgCO}_{3}$ slightly decreases between $\mathrm{pH}$ 6-10. However, the dominant $\mathrm{Hg}$ species, $\mathrm{Hg}(\mathrm{RS})^{+}$, did not show sensitivity to water $\mathrm{pH}$ and water temperature.

\subsubsection{Sensitivity Analysis of Mineral Saturation Index to Water Temperature and $\mathrm{pH}$}

The sensitivity analysis of water temperature and $\mathrm{pH}$ on the mineral precipitation in ENP surface water condition was conducted for temperature ranges of $5-35^{\circ} \mathrm{C}$ and for water $\mathrm{pH}$ range of 2-10.

Figure 69 shows the effect of water temperature and $\mathrm{pH}$ on the SI of dominant minerals in ENP water. The SI of Calcite, Aragonite, Dolomite, and Huntite increases with water temperature. However, temperature does not affect the formation of $\mathrm{Ca}\left(\mathrm{PO}_{4}\right)_{3} \mathrm{OH}$ and Magnesite. The water $\mathrm{pH}$ favors the formation of all the above minerals since the SI increases with water $\mathrm{pH}$. An increase in water $\mathrm{pH}$ increases the precipitation of $\mathrm{CO}_{3}$ minerals (Calcite, Aragonite, Dolomite, Huntite, and Magnesite minerals). Formation of $\mathrm{Ca}_{5}\left(\mathrm{PO}_{4}\right)_{3} \mathrm{OH}$ mineral also increases with $\mathrm{pH}$ because an increase in water $\mathrm{pH}$ favors the production of $\mathrm{OH}^{+}$ion. From Figure 69, it can be concluded that at typical ENP water condition (i.e., $\mathrm{pH} 7-8.2$ and temperature $=23.4{ }^{\circ} \mathrm{C}$ ), water is expected to be supersaturated with Calcite, Aragonite, Dolomite, and $\mathrm{Ca}_{5}\left(\mathrm{PO}_{4}\right)_{3} \mathrm{OH}$ minerals. 

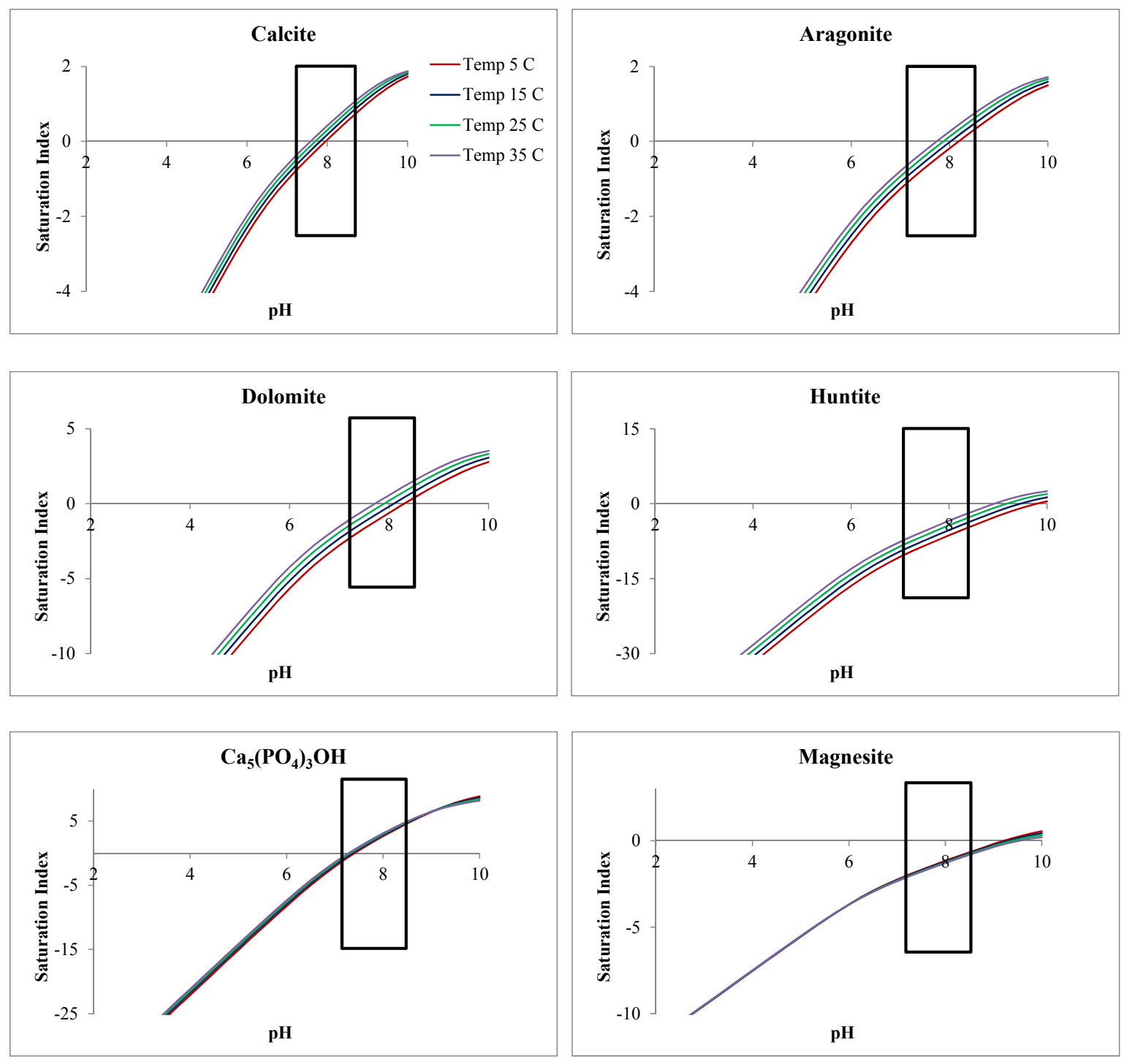

Figure 69 Sensitivity of the mineral precipitation for ENP water with water temperature and $\mathrm{pH}$

\subsubsection{Sensitivity to Salinity on Inorganic Hg Speciation}

For ENP test-bed, seawater intrusion becomes an important variable that can affect water quality. The fate of $\mathrm{Hg}$ and $\mathrm{Hg}$-species distribution is expected to be affected by this variable as well. In this section, the sea and fresh water mixing model was used in order to predict and simulate the $\mathrm{Hg}$-species distribution at various salinity contents 
(Bloom and Crecelius,1983; Conaway et al., 2003; Grassi and Netti, 2002). The freshwater water quality data collected from P33 station, in Table 50, (without DOC) was used for analyzing the the mixing with seawater. The typical seawater water quality data obtained from DBHYDRO, shown in Table 51, was used for the simulations. Simulations were conducted for various percentages of the seawater contents in the mixtures. The $\mathrm{Hg}$ complexation in the mixtures was then investigated.

Table 51 Seawater data (temperature in ${ }^{\circ} \mathrm{C}$, ion concentration in $\mathrm{mg} / \mathrm{L}$ ) (DBHYDRO)

\begin{tabular}{|cc|}
\hline Constituent & Value \\
\hline $\mathrm{pH}$ & 8.2 \\
\hline $\mathrm{Pe}$ & 8.4 \\
\hline Density & 1.0 \\
\hline Temperature & 25 \\
\hline Total $\mathrm{Ca}$ & 412.3 \\
\hline Total $\mathrm{Mg}$ & 1291.8 \\
\hline Total Na & 10768 \\
\hline Total $\mathrm{K}$ & 399.1 \\
\hline Total $\mathrm{Cl}^{-1}$ & 19353 \\
\hline Alkalinity as $\mathrm{HCO}_{3}^{-}$ & 141.7 \\
\hline Total $\mathrm{SO}_{4}$ & 2712 \\
\hline
\end{tabular}

The Hg species distribution plotted against salinity content (\%) in the mixtures is shown in 1-D graphical plot (Figure 70). Figure 71 shows the 3-D graphical plots between 
concentration of $\mathrm{Hg}$-species, salinity content (\%), and percentage of seawater content in the mixtures.

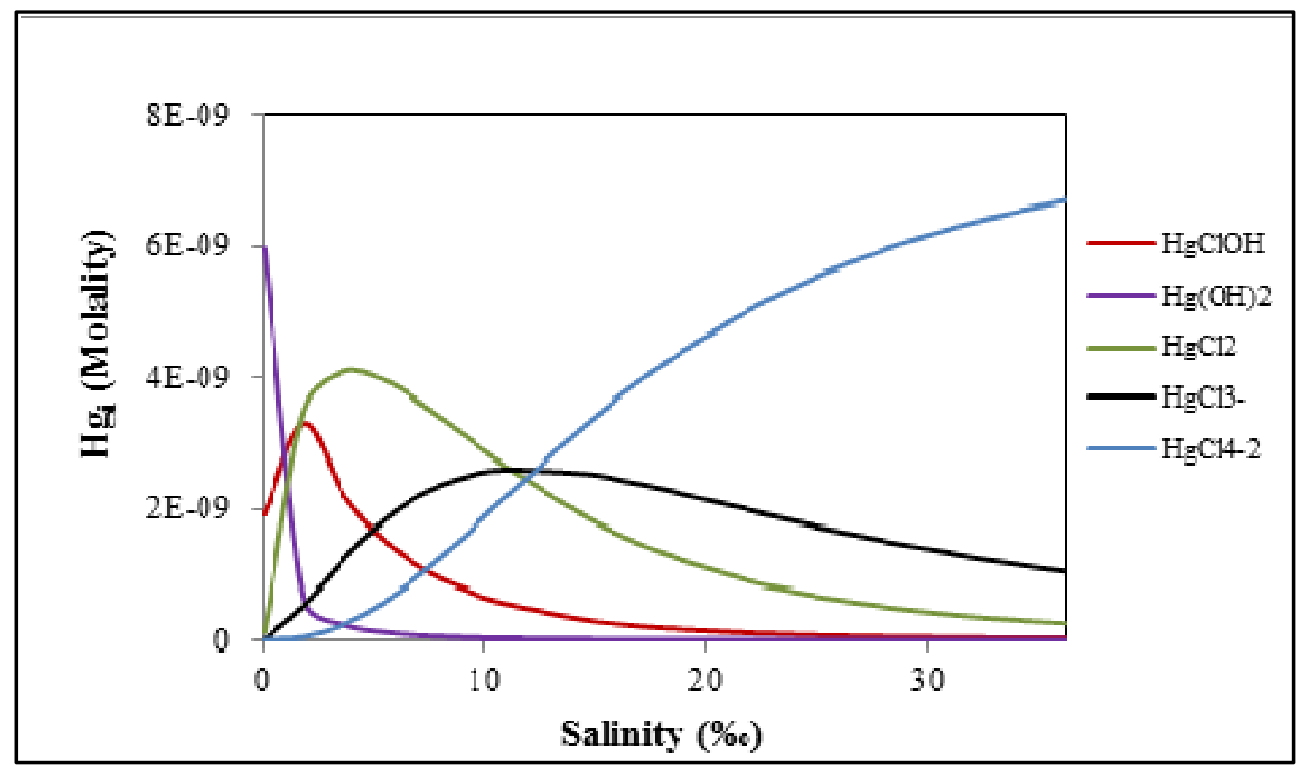

Figure 70 Distribution of $\mathrm{Hg}$-species at various salinities (\%o)

The mixing simulations of fresh and seawater yielded Figures 70 and 71, which describe the effect of salinity on the relative distribution of $\mathrm{Hg}$-species. The figures depict how the different $\mathrm{Hg}$-species are influenced by $\mathrm{Cl}^{-}$concentration. At low salinity (i.e., low $\mathrm{Cl}^{-}$ concentrations) species formation is predicted to be dominated by $\mathrm{HgCl}_{2}$; at higher salinities, $\mathrm{HgCl}_{2}$ declined and $\mathrm{HgCl}_{3}{ }^{-}$and $\mathrm{HgCl}_{4}{ }^{2-}$ increased. The overall implication of the above effect is that, salinity significantly impacts the relative distribution of $\mathrm{Hg}$ species and thus the mobilization of $\mathrm{Hg}$. 

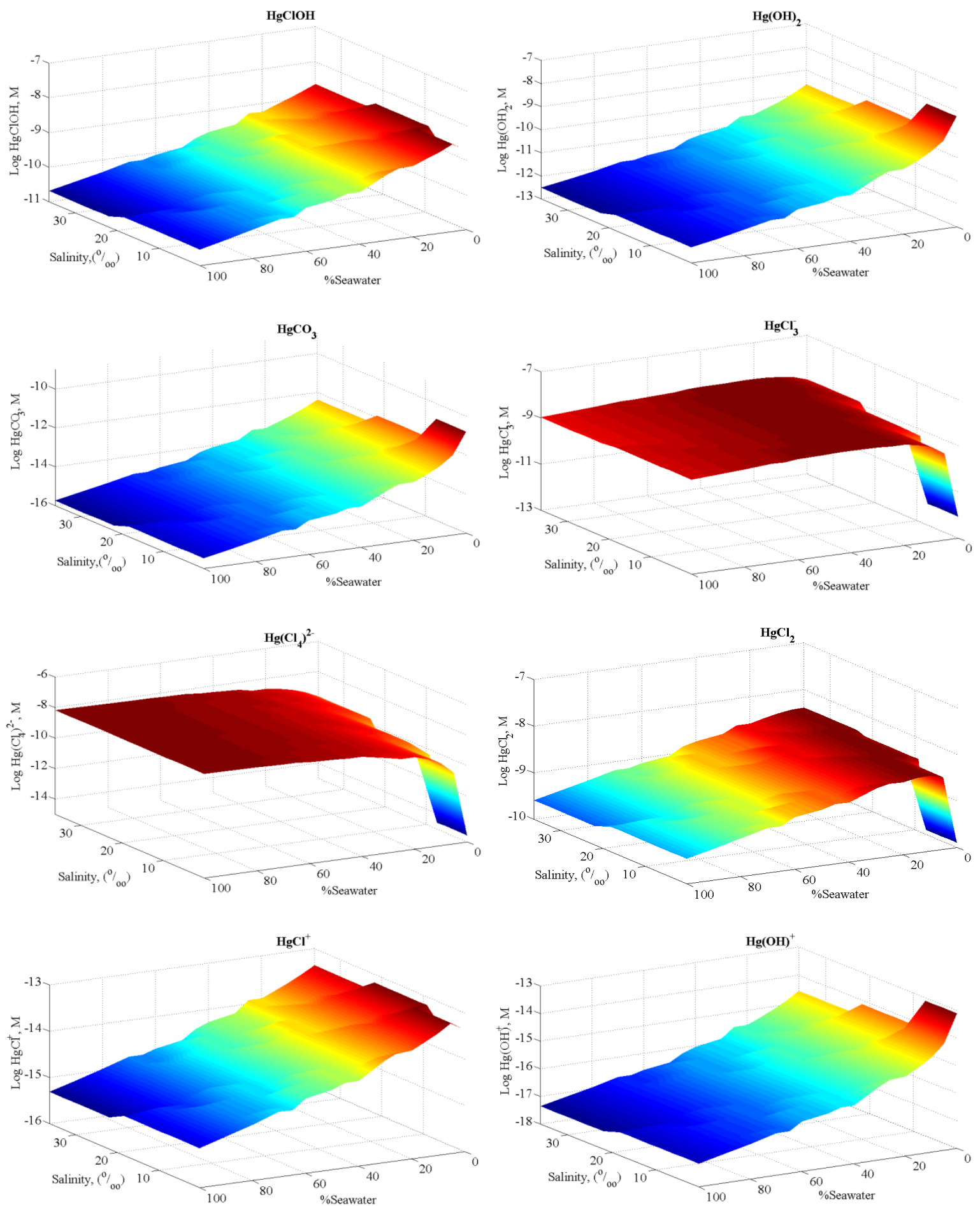

Figure 71 The 3-D graphical distribution of $\mathrm{Hg}$-species as function of salinity (\%o) 


\subsubsection{Hg-S Complexation and the Production of MeHg}

It was mentioned earlier that $\mathrm{Hg}$ binds strongly with the $\mathrm{RS}^{-}$content in DOC. The distribution of $\mathrm{Hg}$ species (Figure 72) that was estimated using the water quality data in Table 50 shows that $\mathrm{Hg}$-DOC complexation (represented by $\mathrm{Hg}(\mathrm{RS})^{+}$species) is the dominant species. Many studies have also reported that the $\mathrm{SO}_{4}$ content in water, especially in reducing water condition where $\mathrm{S}^{6+}$ is reduced to $\mathrm{S}^{2+}$, is the parameter that triggers the production of $\mathrm{MeHg}$ (Bates et al., 2002; Jeremiason et al., 2006; Wang et al., 2009; Weaver et al., 2008; Wnalin et al., 2007). In order to understand the water quality conditions that favor the complexation between $\mathrm{Hg}$ and Sulfur, which can lead to the methylation of $\mathrm{Hg}$, the $\mathrm{Hg}$ species distribution at various redox values in ENP water was evaluated (using the water quality data at P33 station, which is shown in Table 50); the results are depicted in Figure 72.

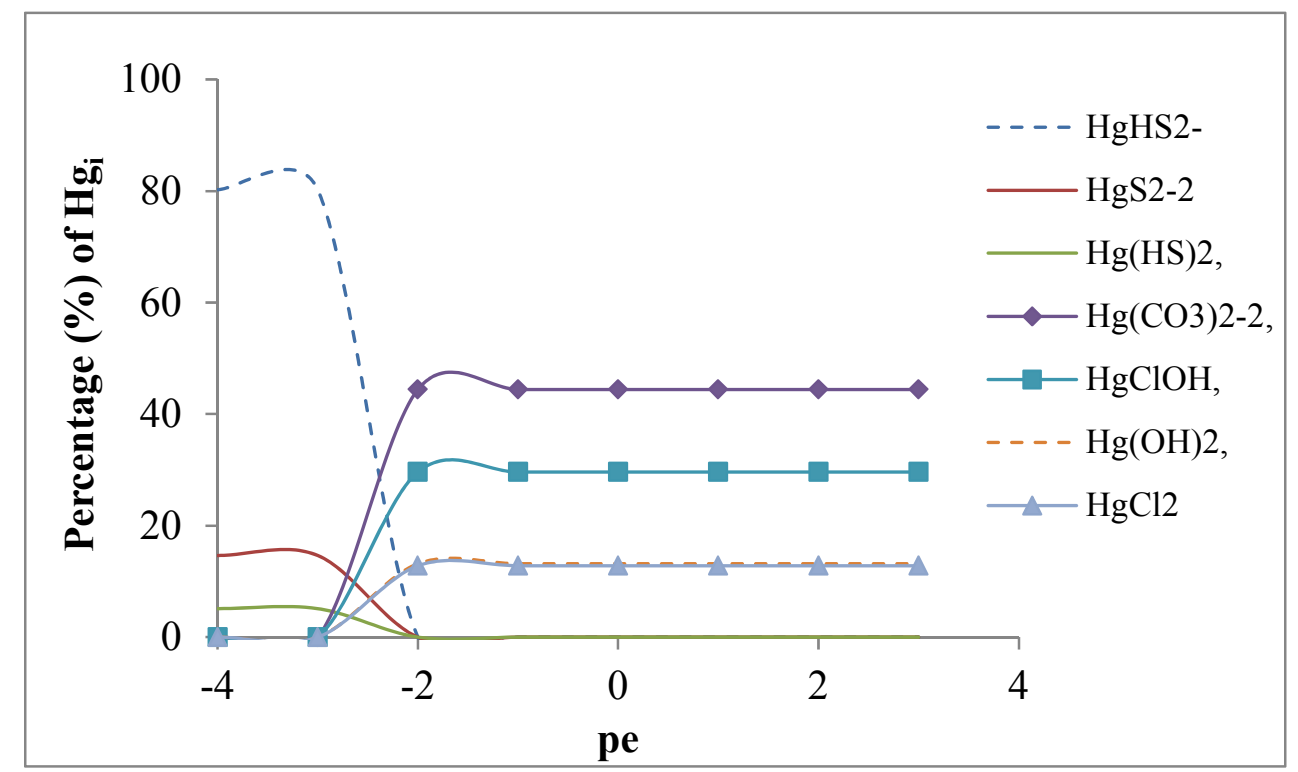

Figure $72 \mathrm{Hg}$ species distribution at various pe in ENP water 
Figure 72 then describes the $\mathrm{Hg}-\mathrm{S}$ species that are estimated to form in water in a reducing condition at a pe from -2 to -4 , with $\mathrm{HgHS}_{2}{ }^{-}$as the dominant species.

In order to evaluate a critical ENP area, where the MeHg is potentially formed, ENP water quality data, including $\mathrm{SO}_{4}$ and $\mathrm{DO}$ concentrations, at different locations were collected.The objective of this aspect of the study was to investigate the location of ENP areas where the probability for $\mathrm{MeHg}$ formation is higher. Thus, that identification can be used to support further research and/or protection efforts.

The ENP critical area is shown with a red boundary line in Figure 73. The ENP area is marked by the green boundary line and is adjacent to the Water Conservation Area (WCA is shown in blue boundary line). The area was divided into 21 sub-areas as shown in Figure 74. The water data collected from DBHYDRO website (2000-2008) at the monitoring stations located in each sub-area was considered representative of the water quality in that sub-area. The water quality data is documented in Table 52.

Table 52 illustrates the $\mathrm{SO}_{4}$ concentrations at the different sub-areas. The concentrations are in the range $6.0-66.0 \mathrm{mg} / \mathrm{L}$. Concentrations of dissolved oxygen (DO), another important parameter, are also considered. High DO presence leads to an oxidizing condition in the water. Lack of or low DO concentration in the water causes a reducing condition, favorable for $\mathrm{Hg}-\mathrm{S}$ complexation. Therefore, water with high $\mathrm{SO}_{4}$ and low DO concentration are of concern. Concentrations of $\mathrm{SO}_{4}$ and DO in ENP water for each sub-area were plotted using the GIS program in Figure 75. 
Table 52 Water quality data at ENP monitoring stations shown in Figure 74 (DBHYDRO)

\begin{tabular}{|c|c|c|c|c|c|c|c|c|c|}
\hline \multirow{2}{*}{ Stations } & \multicolumn{9}{|c|}{ Parameters (mg/L for ions) } \\
\hline & Temp, C & pH & Cl & $\mathrm{SO}_{4}$ & Alkalinity & $\mathbf{C a}$ & $\mathrm{Na}$ & Mg & DO \\
\hline P33 & 27 & 7.4 & 102 & 14.6 & 264 & 86.3 & 66.6 & 18.2 & 3.2 \\
\hline P34 & 28 & 7.3 & 64.9 & 6 & 226 & 125 & 108.4 & 20.81 & 2.5 \\
\hline P35 & 27 & 7.2 & 385.8 & 31.6 & 271.5 & 88 & 199.5 & 27.69 & 0.8 \\
\hline P36 & 27 & 7.4 & 146.1 & 15.1 & 236.6 & 85.2 & 90.65 & 20.62 & 2.4 \\
\hline NE1 & 27 & 7.3 & 138.1 & 19.6 & 261 & 95.6 & 85.9 & 19.52 & 5.0 \\
\hline S176 & 28 & 7.4 & 131.6 & 6.7 & 264.3 & 95.4 & 94.9 & 24.03 & 4.0 \\
\hline L31NNGW1 & 27 & 7.4 & 62 & 7.8 & 150 & 56 & 61 & 15 & 4.0 \\
\hline NP206 & 27 & 7.5 & 72 & 9.9 & 225.1 & 80.2 & 55 & 4.87 & 2.1 \\
\hline S332 & 27 & 7.5 & 58.9 & 7.2 & 224.4 & 81.3 & 73.5 & 10.2 & 0.9 \\
\hline S178 & 27 & 7.4 & 93 & 44.6 & 240.8 & 93.7 & 14.3 & 17.1 & 1.3 \\
\hline S18C & 27 & 7.4 & 93 & 44.6 & 240.8 & 93.7 & 14.3 & 17.1 & 2.1 \\
\hline EPGW & 27 & 7.4 & 920 & 65.7 & 208 & 117 & 491.5 & 45.3 & 5.2 \\
\hline P37 & 27 & 7.1 & 871.7 & 12.3 & 257 & 105 & 18.3 & 5.99 & 5.0 \\
\hline $\mathrm{X} 5$ & 27 & 7.1 & 946 & 23 & 196 & 79.1 & 11.5 & 3.21 & 0.7 \\
\hline $\mathrm{S} 12 \mathrm{C}$ & 27 & 7.5 & 50 & 17 & 196 & 88 & 56.7 & 8 & 3.7 \\
\hline S12A & 27 & 7.5 & 12 & 10 & 208 & 78.9 & 20 & 5 & 4 \\
\hline ENP-TC1 & 27 & 7.4 & 58.9 & 12.5 & 224.4 & 81.3 & 73.5 & 10.2 & 6 \\
\hline ENP-TS1 & 27 & 7.4 & 100 & 27 & 180 & 78 & 27 & 14 & 4.5 \\
\hline ENP-TS5 & 27 & 7.1 & 850 & 36 & 180 & 160 & 120 & 55 & 6 \\
\hline ENP-TS4 & 27 & 7.1 & 600 & 30 & 180 & 140 & 130 & 46 & 4.5 \\
\hline North-River & 27 & 7.1 & 800 & 2.3 & 340 & 74 & 1200 & 54 & 8 \\
\hline
\end{tabular}




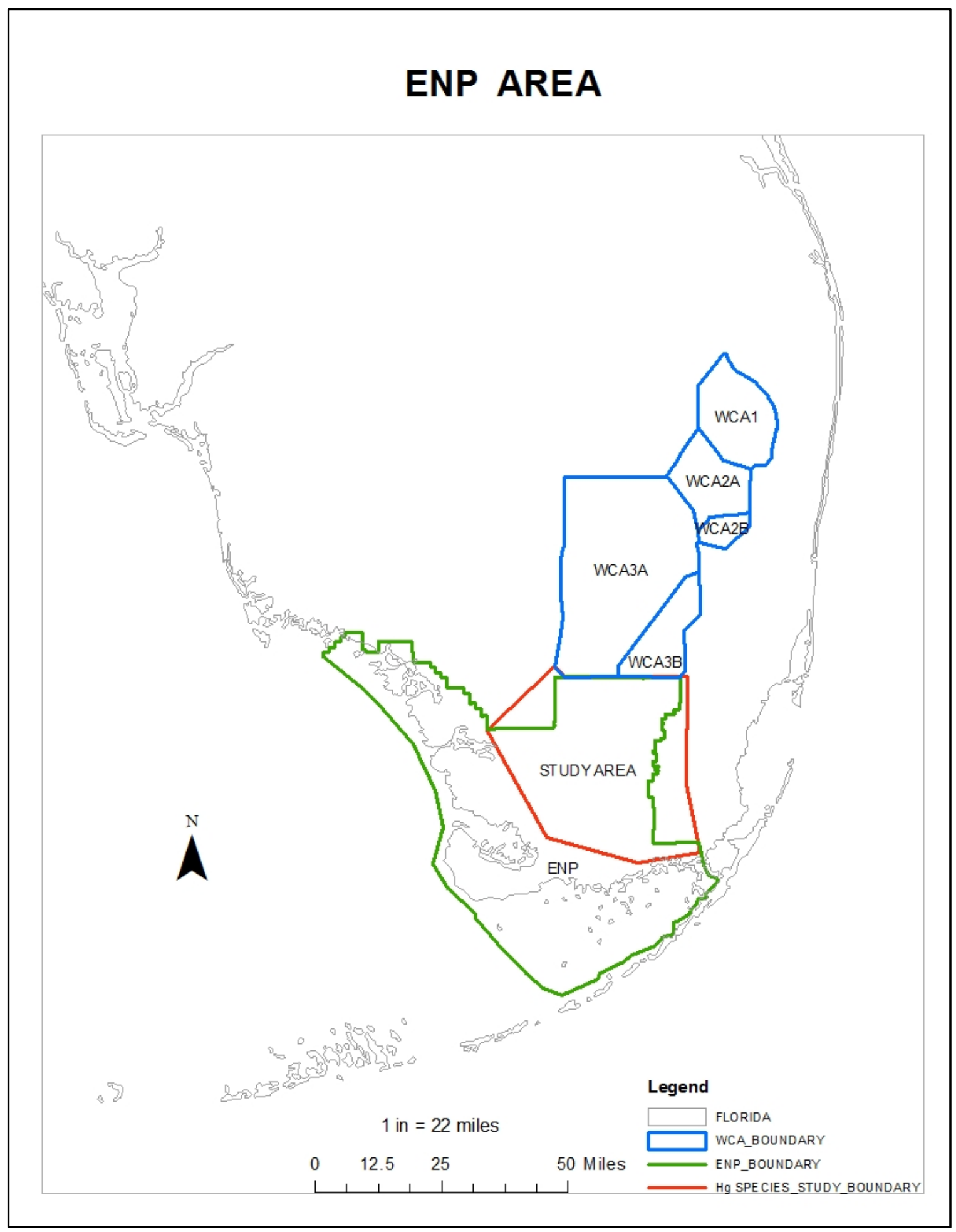

Figure 73 Map for the study area of $\mathrm{Hg}$ speciation distribution in ENP 


\section{ENP STUDY AREA}

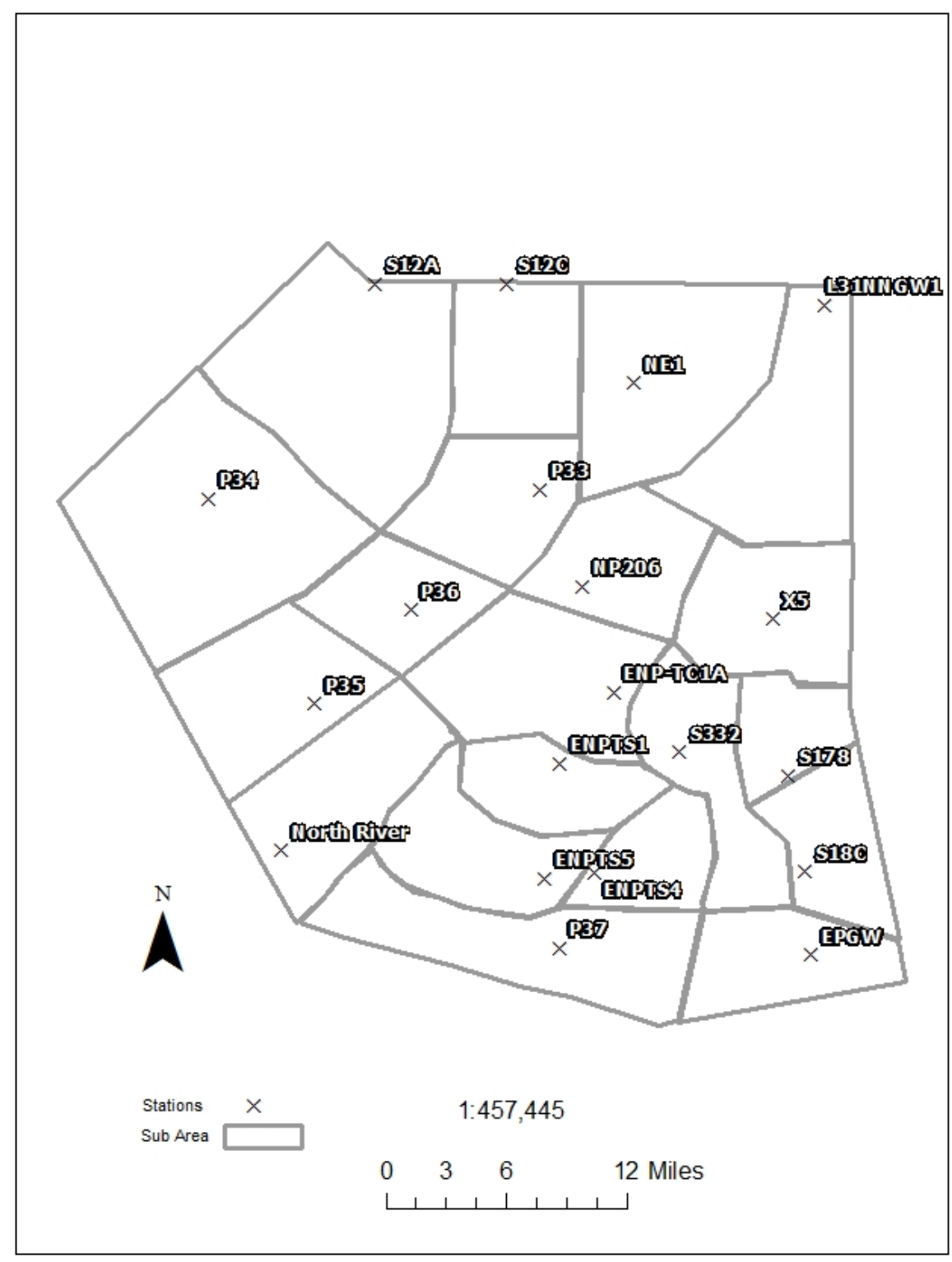

Figure 74 Sub-areas in the ENP 
It can be seen in Figure 75 that, the areas of concern are along the Shark River Slough (P33, P35, P36) and canal C-111 (S178 and S178C). Taylor Slough areas (in vicinity of stations ENPTS1, ENPTS4, ENPTS5, and P37) had high concentration of $\mathrm{SO}_{4}$ .However, they had high DO concentrations also; therefore, the possibility of Hg-S species formation in those areas were very low (Choi and Harvey, 2000; Harvey et al., 2000).

For the Shark River Slough, the results showed potential for Hg-S formation, which later can lead to the methylation of $\mathrm{Hg}$ (i.e., $\mathrm{MeHg}$ ). These results are consistent with the study of Axelrad et al. (2008), who reported that the $\mathrm{Hg}$ concentration in sampled fish (Largemouth bass) in Shark River Slough during 2007 exceeded the USEPA human health fish tissue criterion $(0.3 \mu \mathrm{g} / \mathrm{g})$. The concentration of $\mathrm{Hg}$ in sampled fish in this area ranged between 1.0 $-1.4 \mu \mathrm{g} / \mathrm{g}$. This indicates the presence of MeHg which lead to the $\mathrm{Hg}$ accumulation in the fish skin. 


\section{ENP $\mathrm{SO}_{4}$ and DO CONCENTRATIONS}

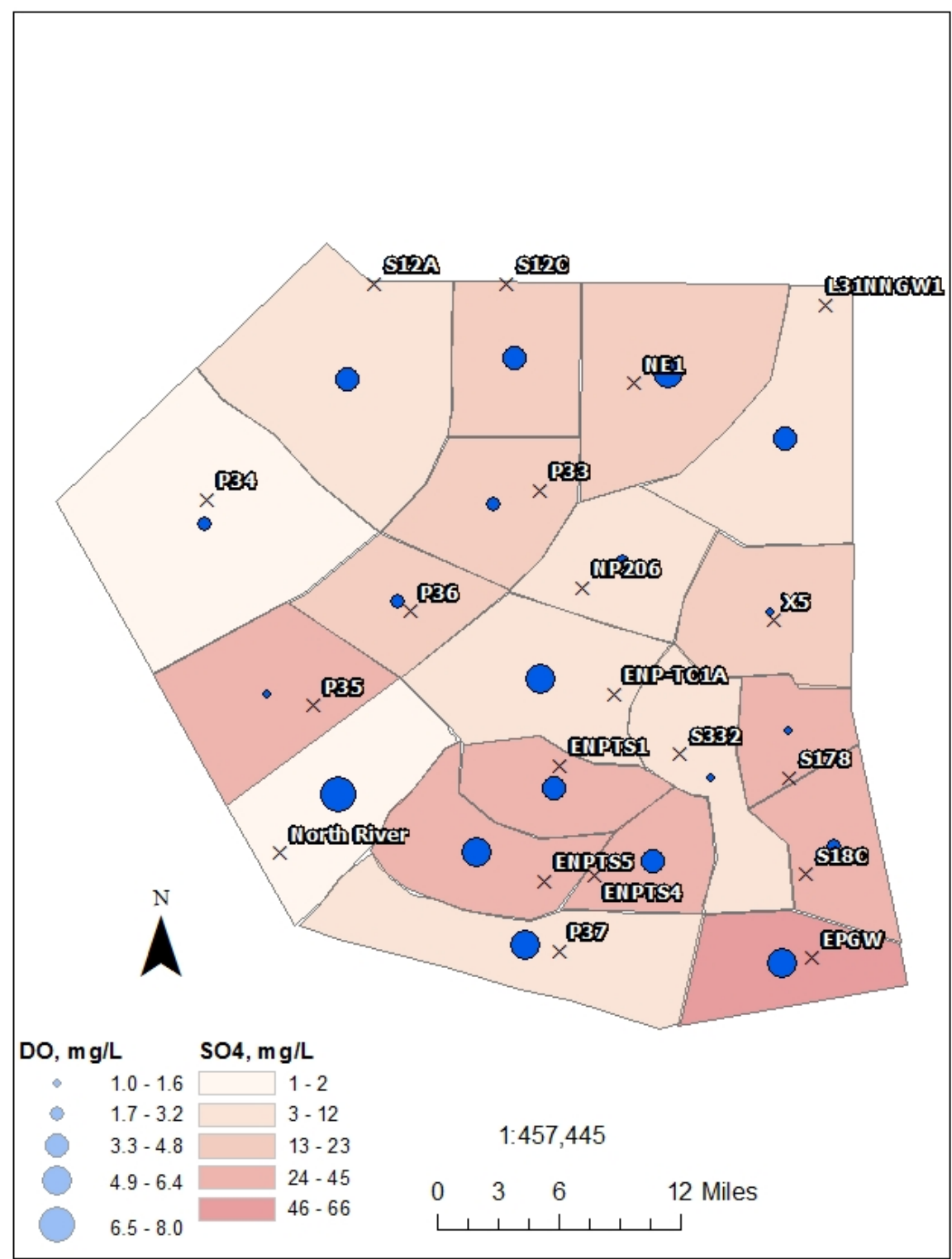

Figure $75 \mathrm{Map}$ of $\mathrm{SO}_{4}$ distribution in ENP area 


\subsection{ENP Test-Bed Simulation - Surface Water Transport Mode}

This section presents the Hg transport study in the Shark River Slough (SRS), where $\mathrm{Hg}$ has accumulated in fish skin as was reported in literature (Adams, and Onorato, 2005; Axelrad et al., 2008; Duvall and Barron, 2000). In this section, the PHREEQCPHAST integrated model of the geochemical PHREEQC and the 3-dimensional flow HST3D model was used to simulate the $\mathrm{Hg}$ transport. PHAST requires three model input files for transport, chemistry, and supporting information databases. All three files can be written in PHREEQC format. The PHREEQC database that was developed previously was used in all the simulations. With the HST3D integration, PHAST has capability to calculate the transport in 3-D flow. The study area and the model domain are shown in Figure 76.

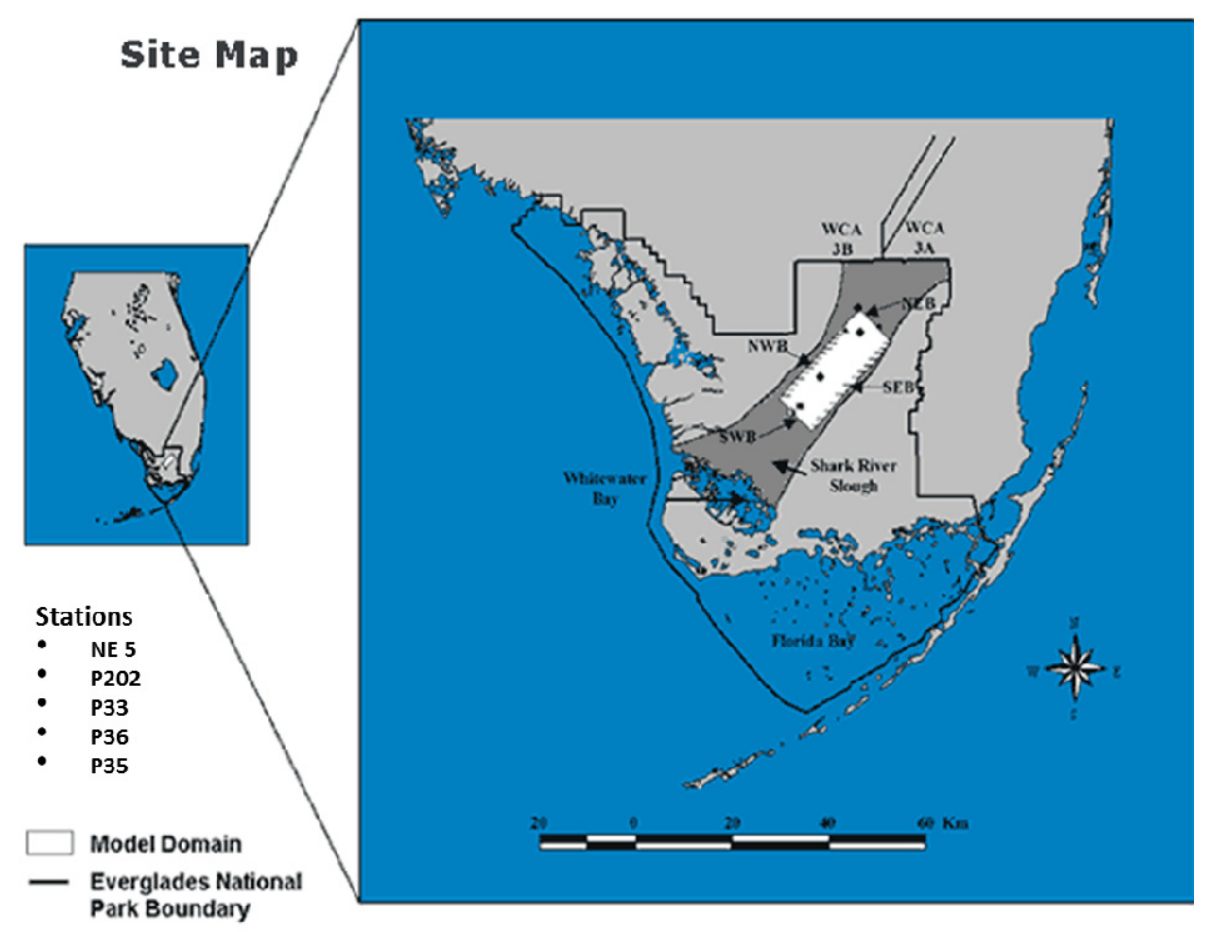

Figure $76 \mathrm{Map}$ of $\mathrm{Hg}$ transport study area and model domain located in ENP Shark River Slough (modified after Harvey et al., 2005) 
The modeling domain shown in Figure 76 covers an area of $27 \mathrm{~km} \times 10 \mathrm{~km}$ of Shark River Slough (Harvey et al., 2002; and Harvey et al., 2005). The head boundaries assumed for the model were at locations NE5 and NP202 (Harvey et al., 2005; Leonard et al., 2006; and Guentzel et al., 2001). The flow direction was assumed to be from NE5 and P202 to P35. The water quality data at different locations (NE5, P202, P33, P36, P35) were collected from DBHYDRO and used in the model (Table 53). The flow parameters used in the model are shown in Table 54 (Harvey et al., 2005 and Leonard et al., 2006).

Table 53 Water quality data at different stations used for the $\mathrm{Hg}$ transport study (DBHYDRO)

\begin{tabular}{|lccccc|}
\hline \multicolumn{1}{r}{ Parameters } & NE5 & P202 & P33 & P36 & P35 \\
\hline $\mathrm{pH}$ & 7 & 7 & 7 & 7 & 7 \\
\hline Temperature, ${ }^{\circ} \mathrm{C}$ & 25 & 25 & 25 & 25 & 25 \\
\hline Alkalinity $(\mathrm{mg} / \mathrm{L})$ & 250 & 241 & 264 & 236 & 271 \\
\hline $\mathrm{Na}(\mathrm{mg} / \mathrm{L})$ & 50 & 45 & 66 & 90 & 199 \\
\hline $\mathrm{Ca}(\mathrm{mg} / \mathrm{L})$ & 70 & 68 & 86 & 85 & 88 \\
\hline $\mathrm{Mg}(\mathrm{mg} / \mathrm{L})$ & 15 & 14 & 18 & 20 & 27 \\
\hline $\mathrm{SO}{ }_{4}(\mathrm{mg} / \mathrm{L})$ & 13 & 12 & 14 & 15 & 31 \\
\hline $\mathrm{Cl}(\mathrm{mg} / \mathrm{L})$ & 10 & 10 & 102 & 146 & 385 \\
\hline $\mathrm{Hg}{ }^{*}(\mathrm{mg} / \mathrm{L})$ & $2.96 \times 10^{-5}$ & $2.96 \times 10^{-5}$ & - & - & - \\
\hline $\mathrm{DOC} * *(\mathrm{mg} / \mathrm{L})$ & 30 & 30 & 30 & 30 & 30 \\
\hline $\mathrm{Peat**}(\mathrm{mg} / \mathrm{L})$ & 1,000 & 1,000 & 1,000 & 1,000 & 1,000 \\
\hline
\end{tabular}

*The average concentration of $\mathrm{Hg}$ in Everglades in $\mathrm{mg} / \mathrm{L}$ (DBHYDRO).

**DOC and peat concentrations were calculated using the information obtained from Drexel et al. (2002). Drexel et al. (2002) reported that the $40 \mathrm{mg} / \mathrm{L}$ of Everglades peat release $1.2 \mathrm{mg} / \mathrm{L}$ of DOC. If peat is considered as an only major source that releases DOC into the water, and since ENP water contains an average $30 \mathrm{mg} / \mathrm{L}$ concentration of DOC, thus from peat and DOC relationship reported in Drexel et al. (2002), peat concentration was estimated to be $1,000 \mathrm{mg} / \mathrm{L}$ and this value was used in this study. 
Table 54 Transport parameters used for Hg transport study in Shark River Slough

\begin{tabular}{|c|c|}
\hline Parameters & Values \\
\hline Model Domain & $27 \mathrm{~km} \times 10 \mathrm{~km}$ \\
\hline Velocity, m/d & $\begin{array}{c}777 \text { (Harvey et al., 2005; Leonard et } \\
\text { al., 2006) }\end{array}$ \\
\hline Dispersivity, $\mathrm{m}$ & 6 (Harvey et al., 2002) \\
\hline Diffusivity, $\mathrm{m}^{2} / \mathrm{s}$ & $1 \times 10^{-9}$ (Harvey et al., 2005) \\
\hline Number of Grid in $\mathrm{X}$ axel & 27 \\
\hline Number of Grid in $\mathrm{Y}$ axel & 10 \\
\hline Number of Grid in $\mathrm{Z}$ axel & 1 \\
\hline Grid size & $1 \mathrm{~km} \times 1 \mathrm{~km}$ \\
\hline Simulation time, years & 200 \\
\hline Grid for NE5 station $\left(\mathrm{X}_{1}, \mathrm{Y}_{1}, \mathrm{Z}_{1}: \mathrm{X}_{2}, \mathrm{Y}_{2}, \mathrm{Z}_{2}\right)$ & $\begin{array}{c}0,0,0: 1,3.1,1 \text { it associated with } \\
\text { water quality from station NE5 }\end{array}$ \\
\hline Grid for NP202 station $\left(X_{1}, Y_{1}, Z_{1}: X_{2}, Y_{2}, Z_{2}\right)$ & $\begin{array}{c}0,3.1,0,: 1,10,1 \text { it associated with } \\
\text { water quality from station NP202 }\end{array}$ \\
\hline Grid for $\mathrm{P} 33$ station $\left(\mathrm{X}_{1}, \mathrm{Y}_{1}, \mathrm{Z}_{1}: \mathrm{X}_{2}, \mathrm{Y}_{2}, \mathrm{Z}_{2}\right)$ & $\begin{array}{c}8.5,5,0,: 9,7.5,1 \text { it associated with } \\
\text { water quality from station P33 }\end{array}$ \\
\hline Grid for P36 station $\left(X_{1}, Y_{1}, Z_{1}: X_{2}, Y_{2}, Z_{2}\right)$ & $\begin{array}{c}17,5,0,: 18,7.5,1 \text { it associated with } \\
\text { water quality from station P36 }\end{array}$ \\
\hline Grid for $\mathrm{P} 35$ station $\left(\mathrm{X}_{1}, \mathrm{Y}_{1}, \mathrm{Z}_{1}: \mathrm{X}_{2}, \mathrm{Y}_{2}, \mathrm{Z}_{2}\right)$ & $\begin{array}{c}25,4.5,0,: 27,5.5,1 \text { it associated with } \\
\text { water quality from station P35 }\end{array}$ \\
\hline
\end{tabular}

The enhanced PHREEQC database was used in all the simulations. The simulations assumed that the Hg entered the model domain at NE5 and NP202, where there were existing peat and DOC. Peat was considered to be part of the sediment column and it does not move with the water, while the DOC does flow with the water in dissolved form. $\mathrm{Hg}$ then binds and moves along with the DOC. This binding is expected 
because of the strong binding constant between $\mathrm{Hg}$ and DOC (log $\mathrm{K}=23.2$ for a strong site and 10 for a weak site). Figure 77 shows that the $\mathrm{Hg}$-DOC concentration is predicted to be high at the beginning of the modeling domain, around NE5 and NP202, where the $\mathrm{Hg}$ was introduced into the model. $\mathrm{Hg}$ binds strongly to the $\mathrm{DOC}$ and forms $\mathrm{Hg}-\mathrm{DOC}$ at a concentration of about $8.6 \mathrm{ng} / \mathrm{L}$, which is $27 \%$ of the initial $\mathrm{Hg}$ concentration. The transport of $\mathrm{Hg}-\mathrm{DOC}$ is slow, due to the low velocity, which is approximately $0.9 \mathrm{~cm} / \mathrm{s}$ or $777 \mathrm{~m} / \mathrm{d}$. The estimated hydraulic retention time of ENP water is approximately 11 days.

Figure 77 also shows the theoretical transport expectation of Hg-DOC at different time intervals $(0-200$ years $)$. At year 5 , the $\mathrm{Hg}$-DOC covers $30 \mathrm{~km}^{2}$ and it reaches 100 $\mathrm{km}^{2}$ at year 200. Figure 78 shows that the concentration of $\mathrm{Hg}$-DOC decreases as it travels from the sources. The $\mathrm{Hg}-\mathrm{DOC}$ concentration at any particular point, for instance at P33, increases with time (for instance, the concentration at P33 at year 200 is higher than in year 50 or later on). This is because of the low ENP water velocity. Of course, the concentrations increase over time within the modeling domain, as Hg-DOC and other species. 


\section{Hg-DOC 0 year}

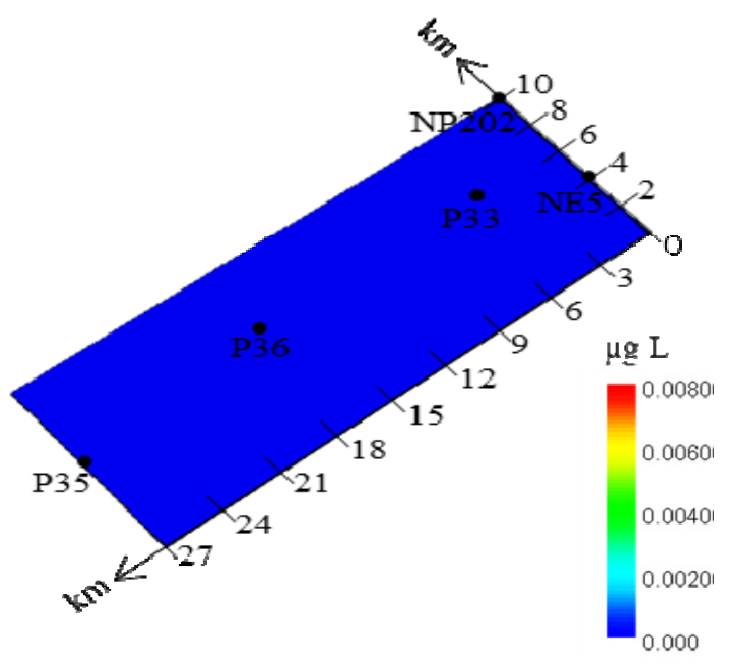

20 years

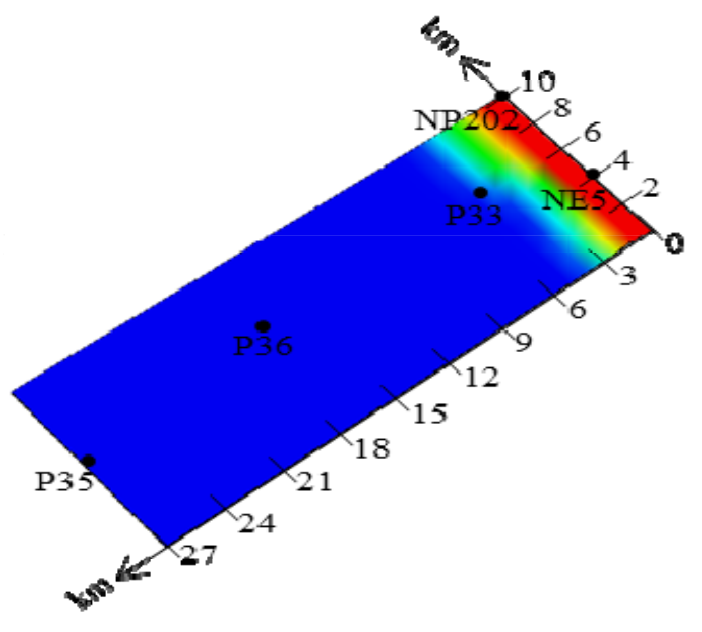

60 years

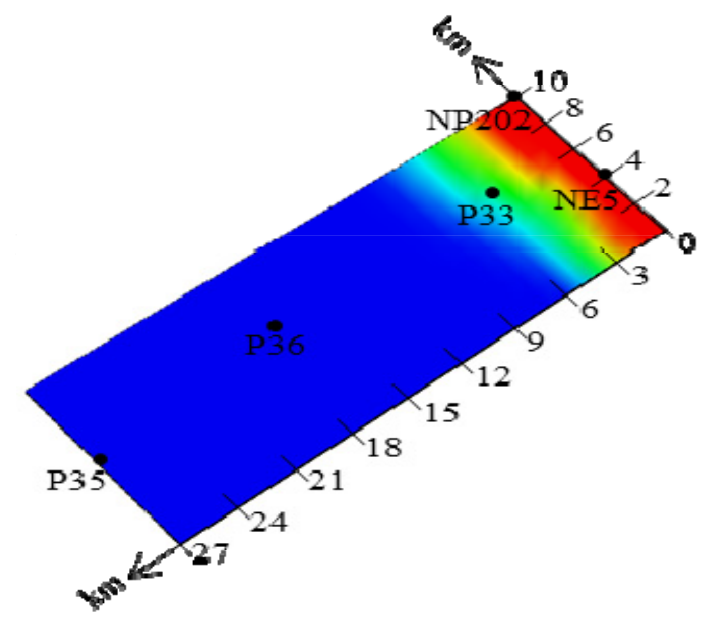

5 years

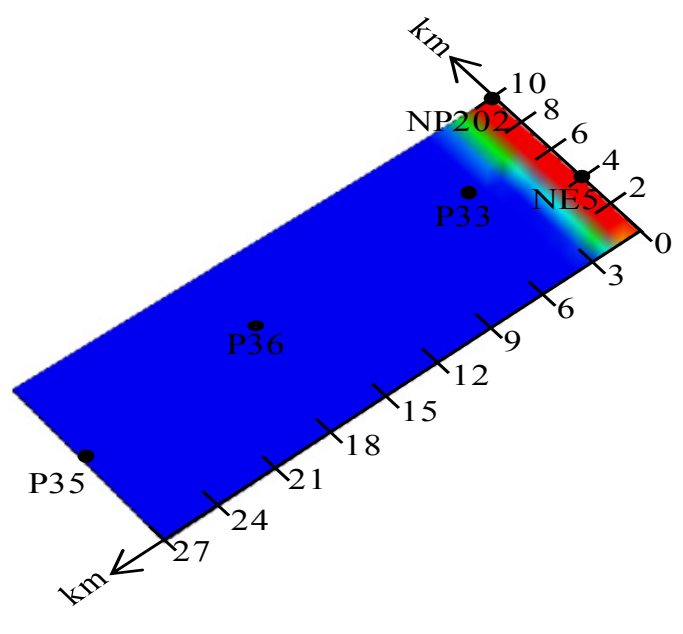

40 years

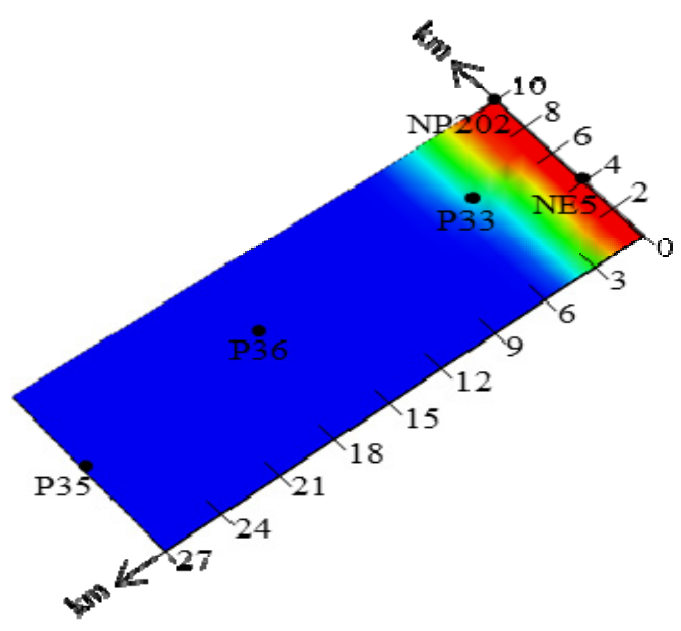

80 years

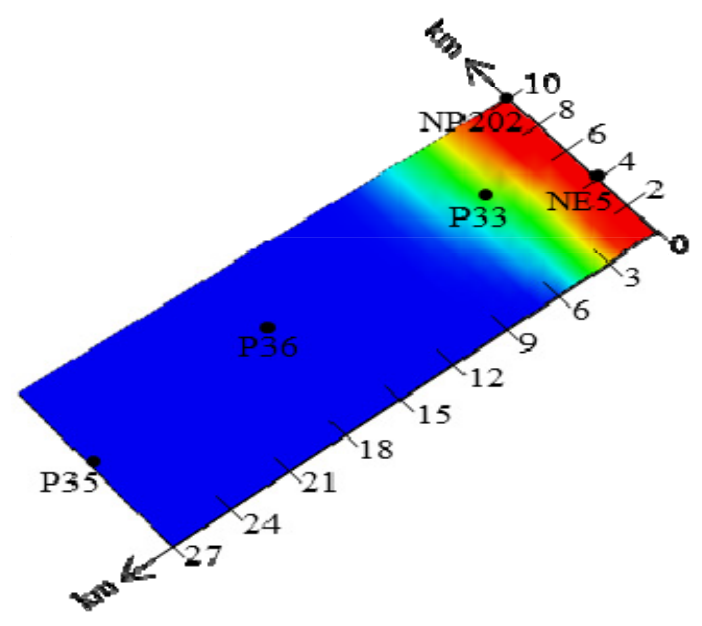



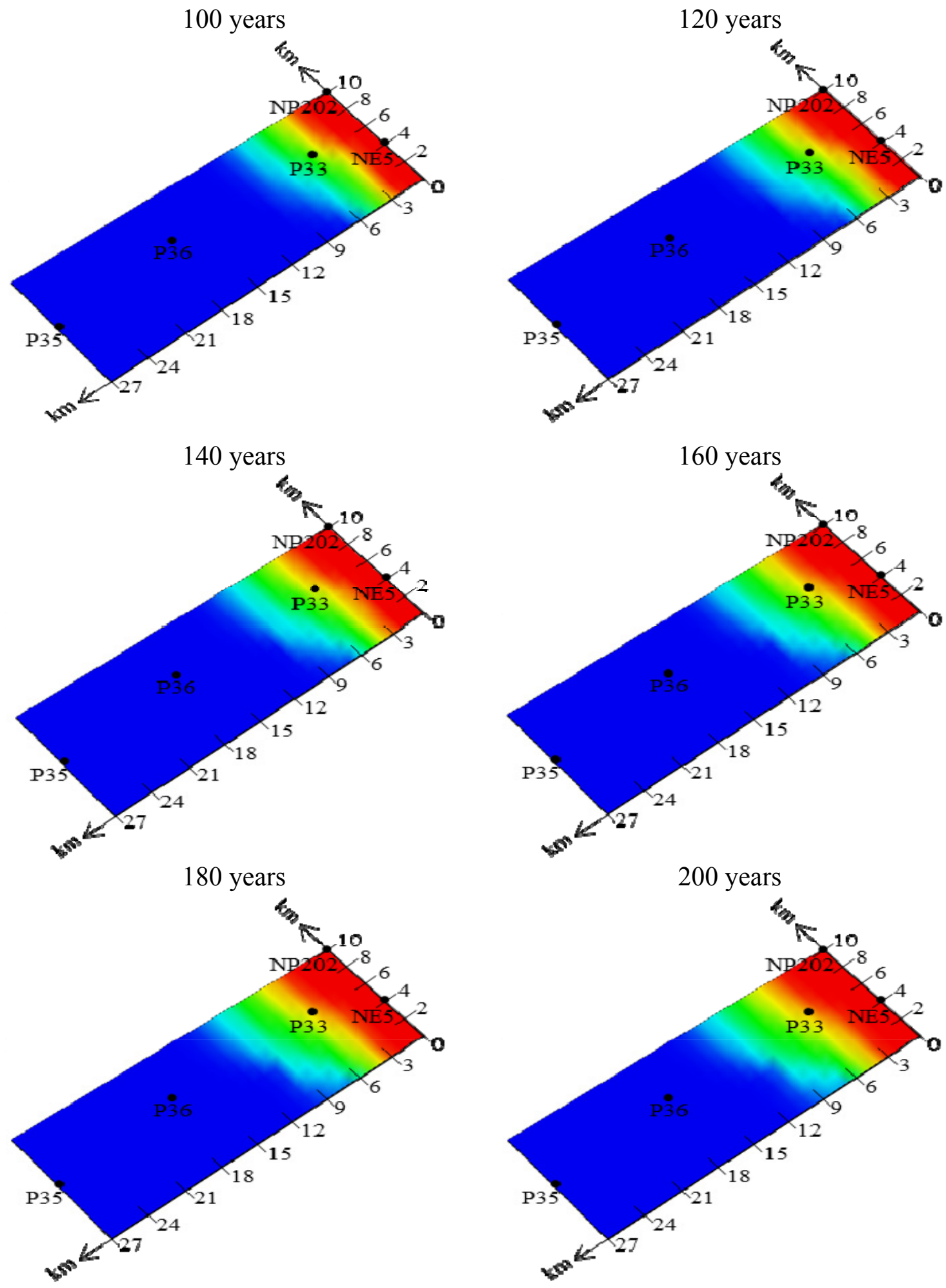

Figure $77 \mathrm{Hg}-\mathrm{DOC}$ species transport in Shark River Slough $(0-200$ years $)$ 


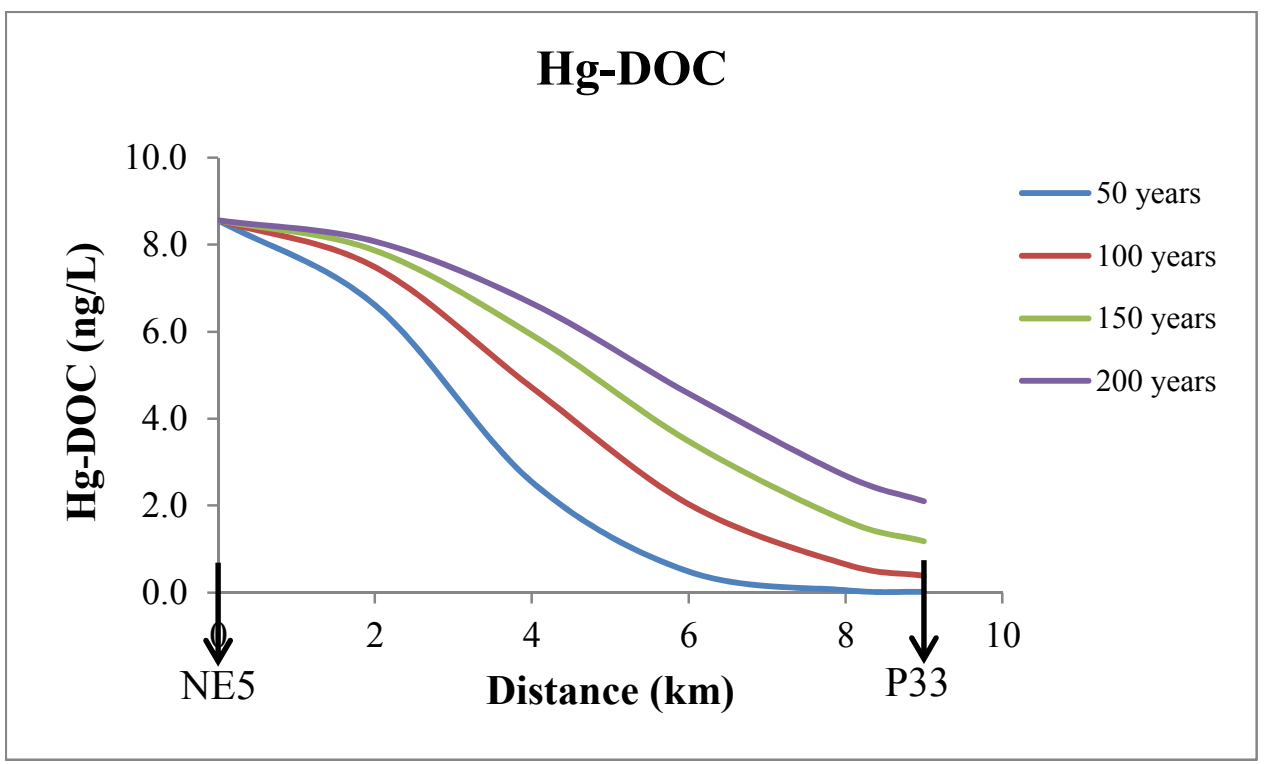

Figure $78 \mathrm{Hg}-\mathrm{DOC}$ concentration at NE5 and P33 stations at different time periods

Figure 79 depicts the effect of $\mathrm{Hg}$ retardation by peat sediments. With an average Hg-Peat log binding constant of 22 for a strong site and 11.8 for a weak site, an $\mathrm{Hg}$-Peat concentration in Shark River Slough of $21.6 \mathrm{ng} / \mathrm{L}$ is obtained at the beginning of the modeling domain where $\mathrm{Hg}$ is introduced. This is about $73 \%$ of the initial $\mathrm{Hg}$ concentration. Although, the binding constants between $\mathrm{Hg}$ and peat is lower than those for $\mathrm{Hg}-\mathrm{DOC}$, the rich amount of peat in ENP water provides more sites for $\mathrm{Hg}$ to attach to peat. 

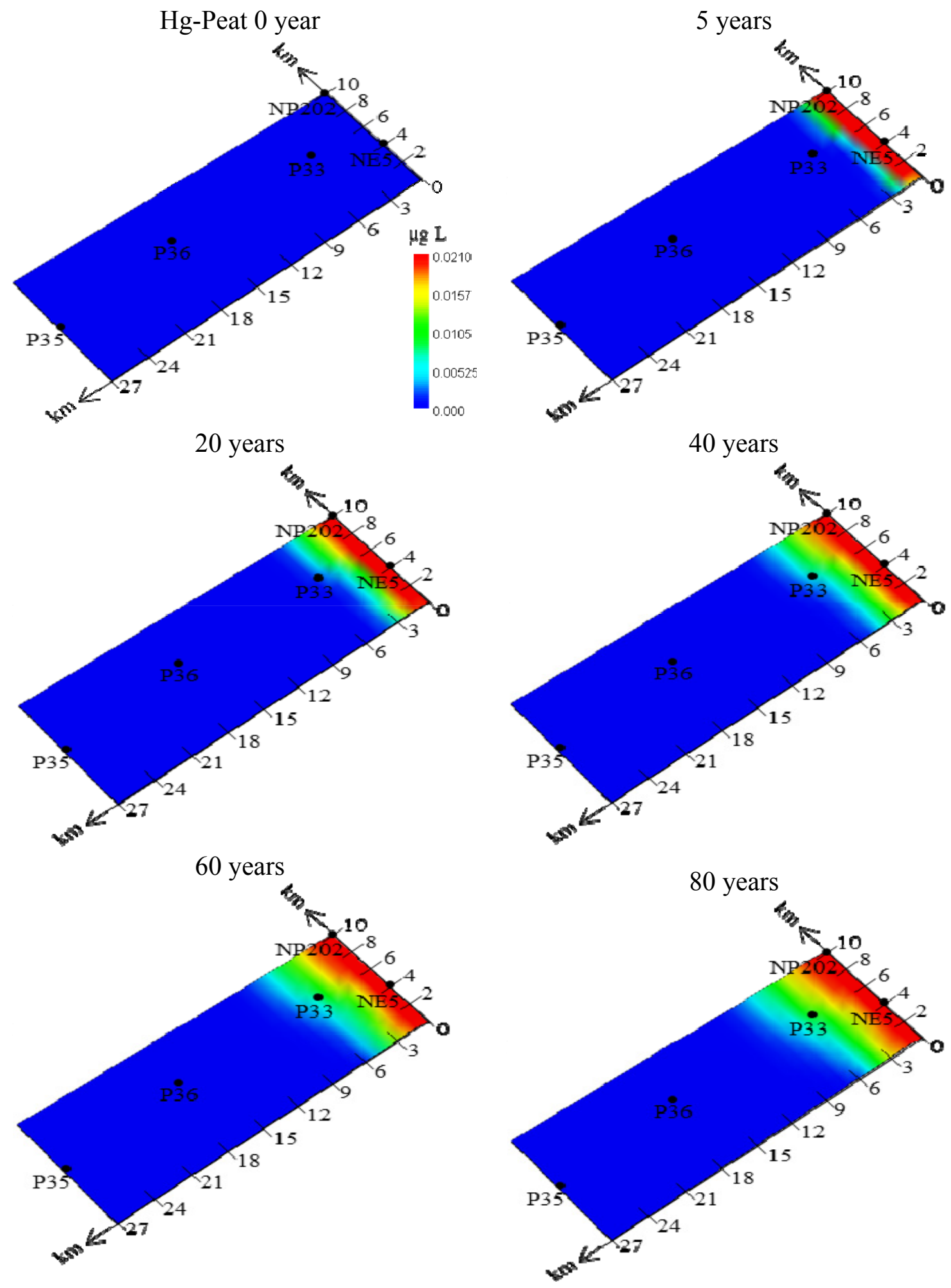

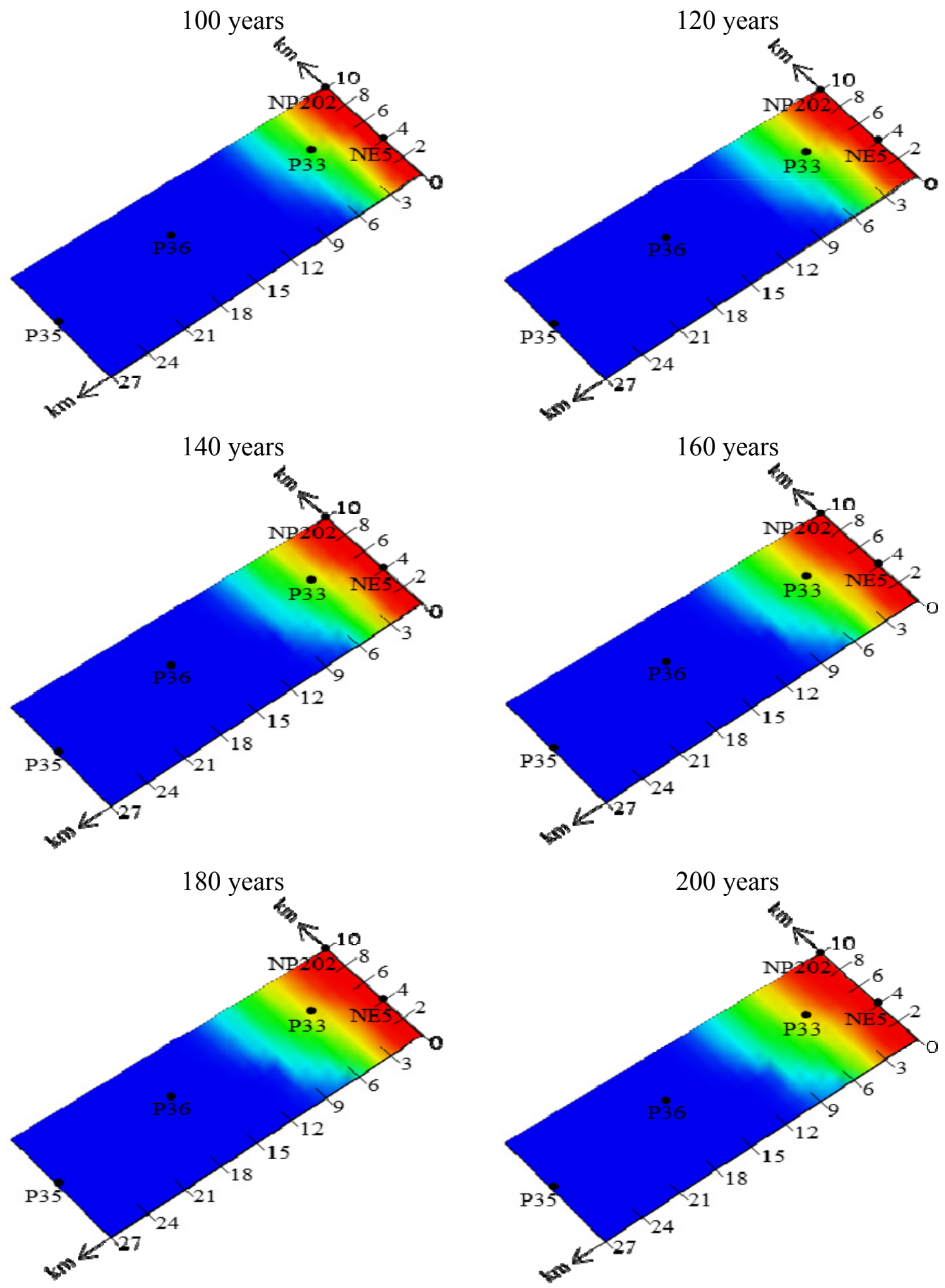

Figure 79 Hg-Peat complexation in Shark River Slough (0 - 200 years) 
Figure 80 illustrates that the Hg-Peat concentration decreases with increasing distance and this may be attributed to the decrease in available free $\mathrm{Hg}$ along the travel distance. The Hg-Peat complex concentration, at any point (for instance P33) along the travel distance, is estimated to increase with time in relation to the ENP water velocity. $\mathrm{Hg}$ attached on peat may most possibly be retained at the slough bottom and thus "immobilized".

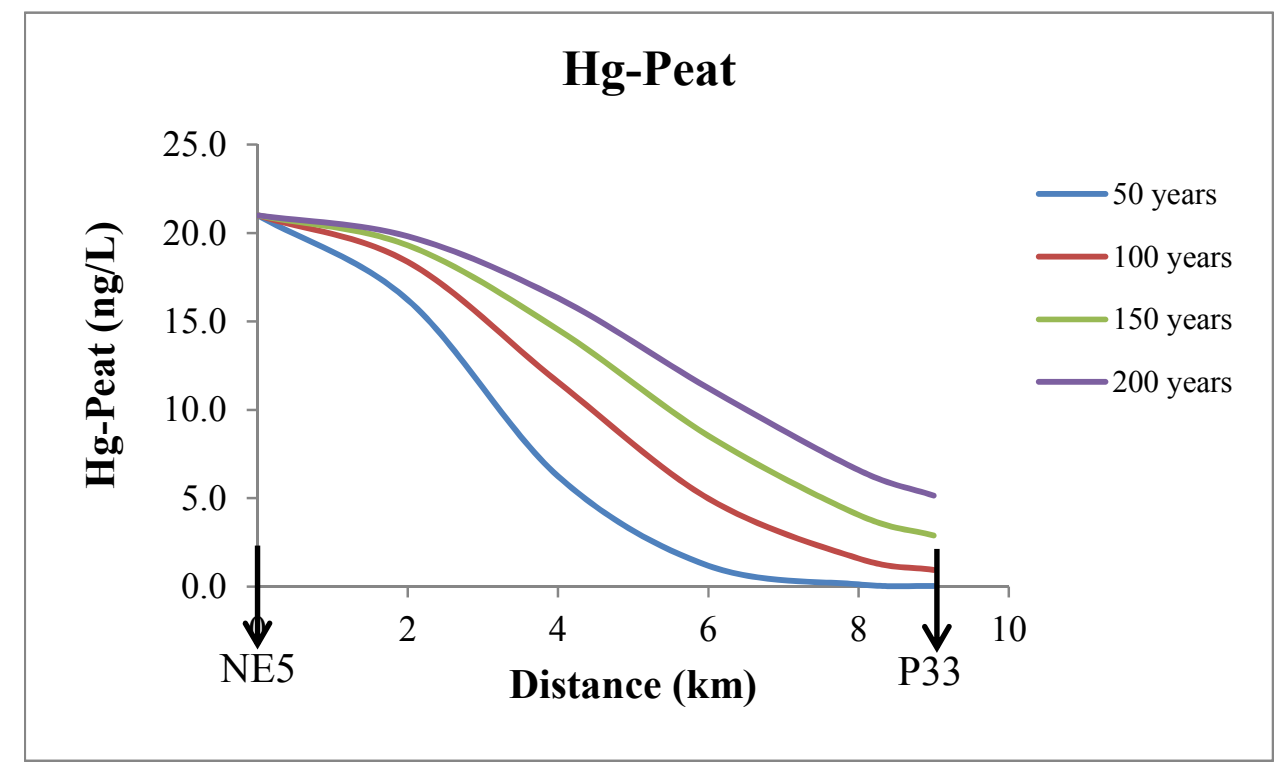

Figure $80 \mathrm{Hg}$-Peat concentration at NE5 and P33 stations at different time periods

The remaining trace amount of formed $\mathrm{Hg}, 6 \times 10^{-14} \mu \mathrm{g} / \mathrm{L}$, moves with water. This amount is available to complex with inorganic ions (i.e., inorganic-Hg complexes). The transport of inorganic-Hg $(0-200$ years $)$ in Shark River Slough is described in Figure 81. 


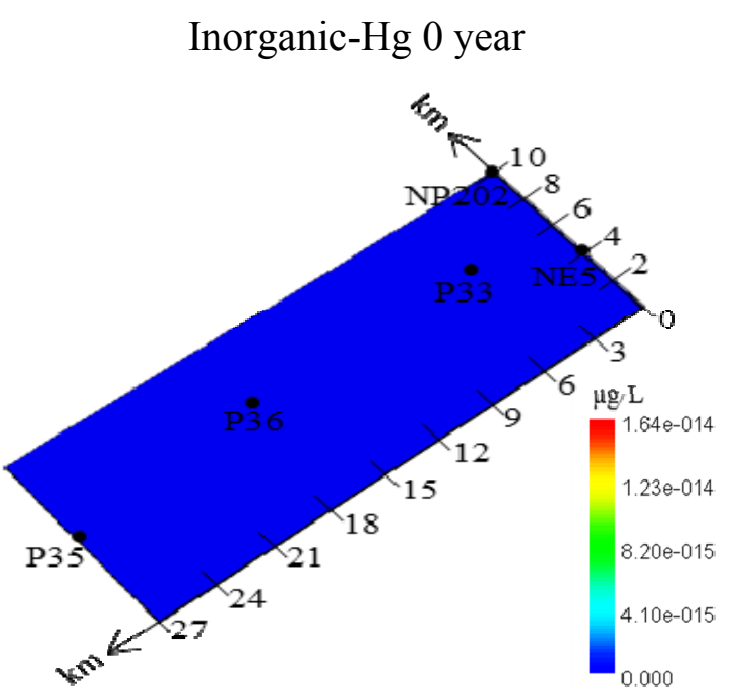

20 years

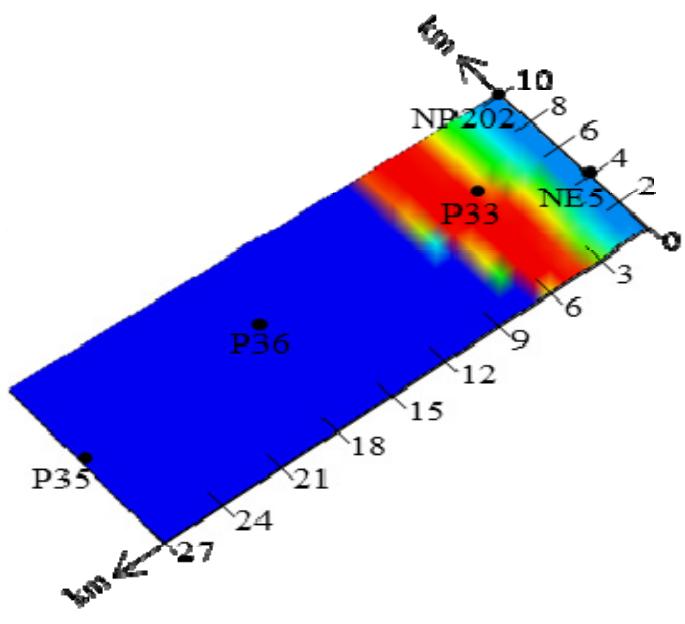

60 years

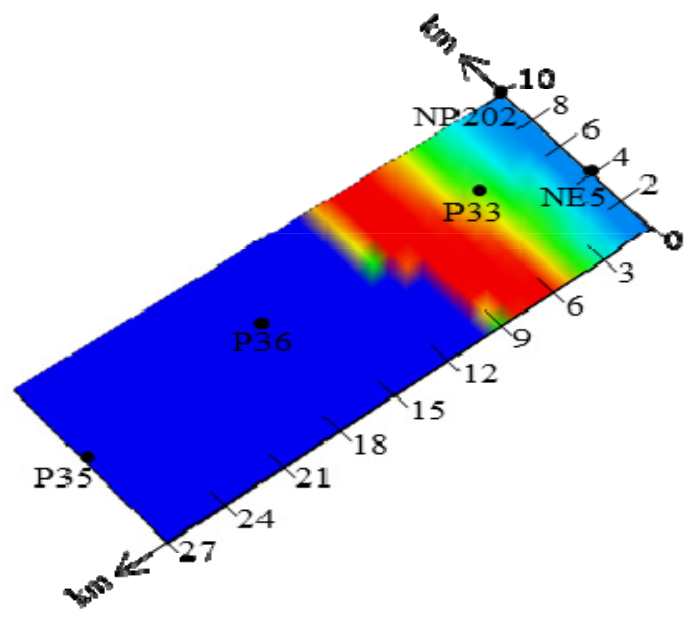

5 years

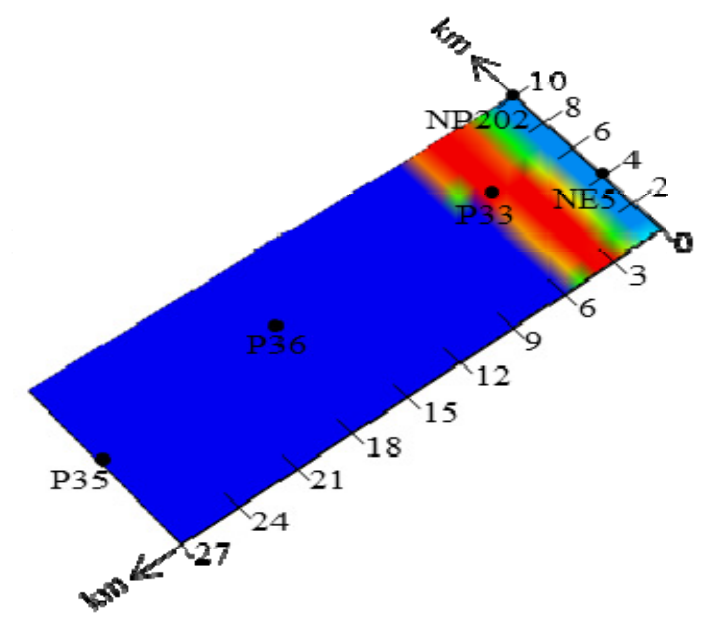

40 years

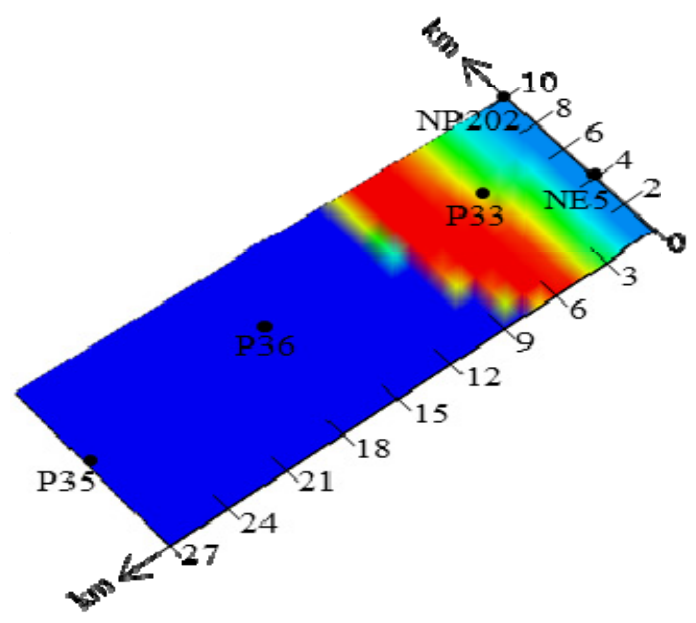

80 years

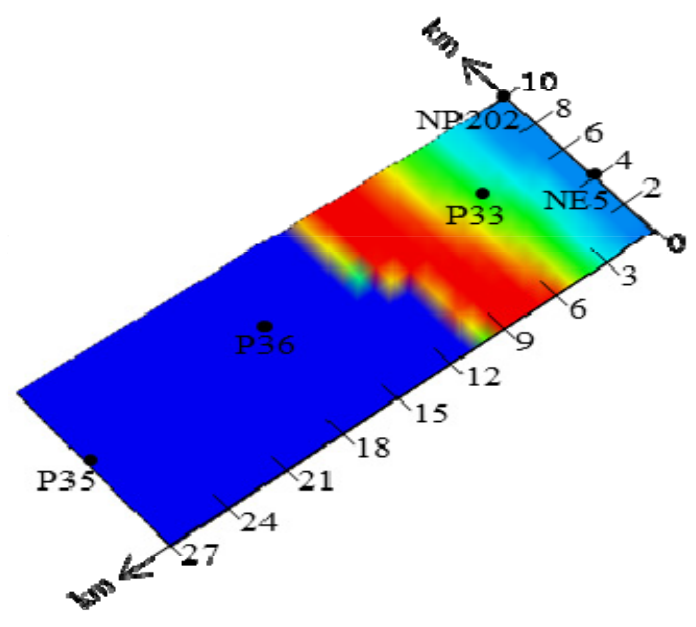



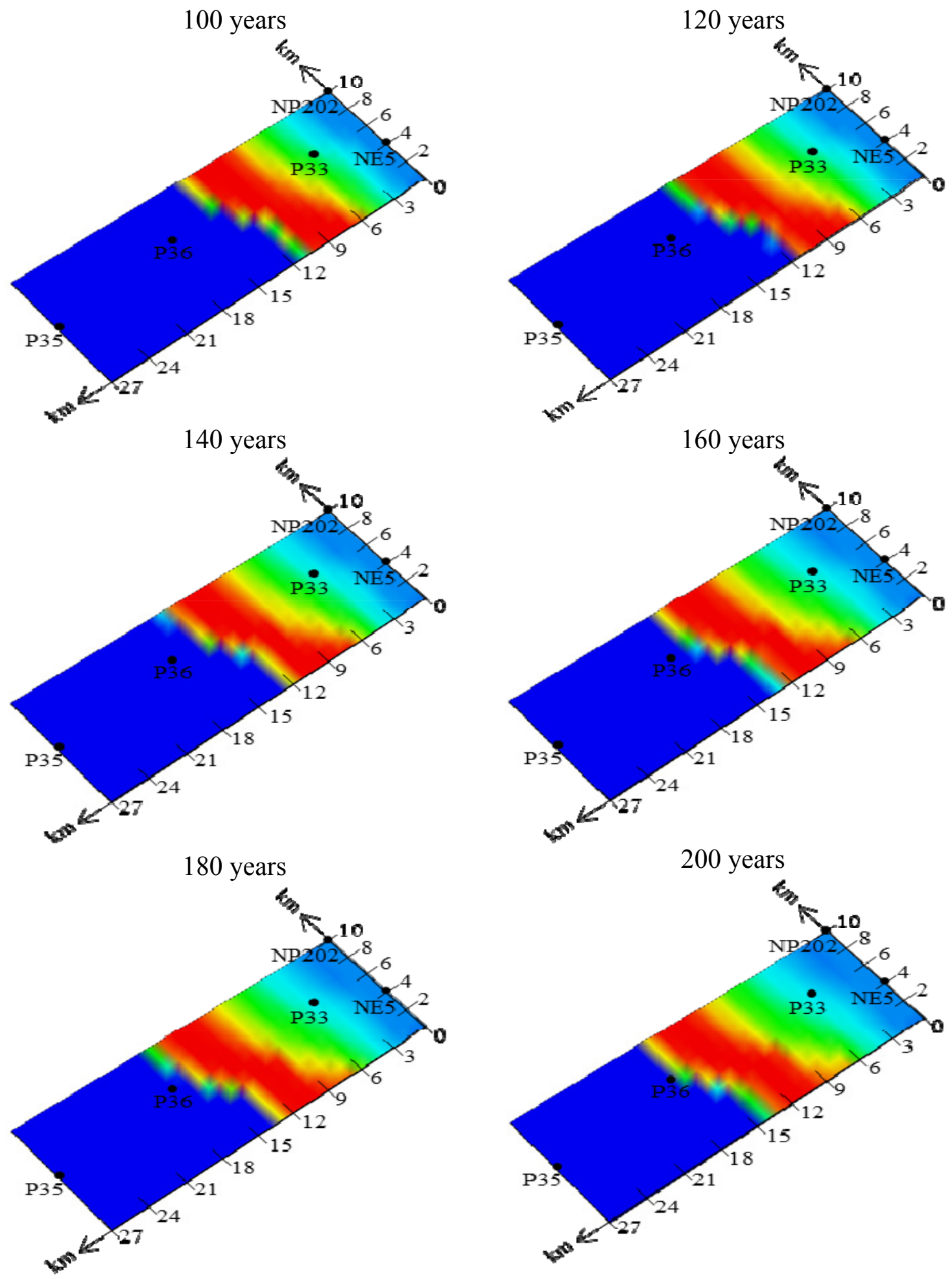

Figure 81 The transport of inorganic Hg in Shark River Slough (0 - 200 years) 
Analysis of Figure 81 points out that when $\mathrm{Hg}$ is introduced it binds to DOC and peat; as a result, the inorganic-Hg complex fraction is expected to be low at the beginning. For the velocity of ENP water considered here, inorganic-Hg is expected to cover $60 \mathrm{~km}^{2}$ after 5 years and about $150 \mathrm{~km}^{2}$ after 200 years. However, inorganic-Hg is much smaller, trace amounts, than the organic complexes to DOC and peat. 


\section{CONCLUSIONS}

This chapter provides a detail description of the conclusions that were drawn from the research work. It also summarizes how the research was able to address the objectives and questions that were posed in Chapter 1. The PHREEQC model developed in this research, with a significantly enhanced $\mathrm{Hg}$ database, is capable of predicting the behavior of various $\mathrm{Hg}$-species in a variety of processes. These include dissolution/precipitation, ion exchange, and surface complexation. In addition, the enhanced PHREEQC model, coupled with the transport model offers a computational tool to be used in site applications (specific site data input is required), to understand the fate and transport of $\mathrm{Hg}$ in the aquatic environments of interest.

\subsection{Enhanced Model Confirmation}

The enhanced model was confirmed using documented experimental and field data. This strengthened the confidence in the model and its capability to simulate $\mathrm{Hg}$ processes and transport.

Using the experimental data documented in relevant literature, the enhanced model was tested to predict $\mathrm{Hg}$ species for a wide range of water $\mathrm{pH}$ conditons (2-10). Overall, the comparisons between the model results and those from literature were satisfactory.

The model was tested using SFWMD field data to study the capability to calculate major ions, which are typical constituents in all aqueous environments. The model prediction of major ions as function of salinity, were comparable with the 
observed data collected from over 30 monitoring wells in the SFWMD area. This indicates that: 1) the enhanced model is capable of simulating the geochemical processes for major ions, which are expected to interact with $\mathrm{Hg}$ in aqueous environments; and 2) the enhanced model is capable of capturing the effect of salinity on chemical processes.

An Hg transport simulation was conducted using the enhanced PHREEQC model in order to study the solute transport in a groundwater setting at Oak Ridge, TN. The goal was to determine the effects of ion-exchange and surface complexation on $\mathrm{Hg}$ transport. The model results compared well with the empirical data and proved the capability of the PHREEQC coupled-transport model. The enhanced model is an effective tool and can be used to simulate the hydrogeochemical transport of $\mathrm{Hg}$ in a groundwater setting. There is a lot of potential for the enhanced PHREEQC model as a tool in the screening, selection and monitoring of remediation technologies, for $\mathrm{Hg}$ contaminated groundwater sites, such as EFPC.

\subsection{Fundamental Scenarios and Analysis}

The enhanced model showed that the Hg species concentrations were influenced by the pe and $\mathrm{pH}$ of water. Under oxidizing conditions, $\mathrm{HgCl}_{2}, \mathrm{HgClOH}$ and $\mathrm{Hg}(\mathrm{OH})_{2}$ were the dominant species. $\mathrm{HgCl} 2$ was dominant in the $\mathrm{pH}$ range of 2.0-7.0 and $\mathrm{HgClOH}$ in the range of $7.0-7.5 . \mathrm{Hg}(\mathrm{OH})_{2}$ was the dominant species for $\mathrm{pH}>7.5$. Cinnabar was the dominant species under reducing water conditions for all $\mathrm{pH}$.

The enhanced model showed that the exchangers affected the Hg concentration in the water through the ion exchange process in the order of Illite $<$ Montmorillonite $<$ Vermiculte. The effect of ion exchange increased with the CEC of the exchanger. This 
result was consistent with the previous studies. The model results, with the improved $\mathrm{Hg}$ surface complexation database for $\mathrm{Fe}(\mathrm{OH})_{3}$, Gibbsite, and Kaolinite, showed that the surface complexation process affected the $\mathrm{Hg}$ concentration. These sorbents can complex strongly with $\mathrm{Hg}$ and hinder its transport. The effect of these minerals on $\mathrm{Hg}$ are in the order of Kaolinite $<$ Gibbsite $<\mathrm{Fe}(\mathrm{OH})_{3}$. The enhanced model also showed that $\mathrm{Hg}(\mathrm{OH})_{2}, \mathrm{Hg}(\mathrm{OH})^{+}$and $\mathrm{HgOHCl}$ can complex with the minerals better than $\mathrm{HgCl}_{2}$, $\mathrm{HgCl}_{3}{ }^{-}$and $\mathrm{HgSO}_{4}$ species for $\mathrm{pH}$ in the range 4.5-8.5.

The effect of ion exchange on $\mathrm{Hg}$ transport was observed to be low in the groundwater and surface water settings that were studied. This may be related to either the low exchange equilibrium constant or the low concentrations of exchangers or both that are expected in typical ground and surface water settings.

The effect of surface complexation on $\mathrm{Hg}$ transport was also estimated in both typical groundwater and surface water settings for Gibbsite, Kaolinite and $\mathrm{Fe}(\mathrm{OH})_{3}$. Kaolinite was observed to have no effect on $\mathrm{Hg}$ transport in the studied surface water setting. This may be attributed to its low equilibrium constant or low expected concentrations or both.

\subsection{EFPC Test-Bed}

At the typical conditions of the water at East Fork Poplar Creek (EFPC) (water $\mathrm{pH} 7.0-9.2$ and temperature of $25^{\circ} \mathrm{C}$ ), the most dominant species, as predicted by the model, were $\mathrm{Hg}(\mathrm{OH})_{2}$ and $\mathrm{HgClOH}$. The formation of $\mathrm{Hg}(\mathrm{OH})_{2}$ increased with water $\mathrm{pH}$ and temperature. For water $\mathrm{pH}$ between 2.0-7.0, an increase in water $\mathrm{pH}$ and temperature favored the production of $\mathrm{HgClOH}$. 
Simulation results predicted the water to be supersaturated with Ferrihydrite, Goethite, Magnesioferrite, Hematite, $\mathrm{FCO}_{3}$ Aptite, Lepidocrocite, Hydroxylapatite, and Arogonite. The formation of these minerals increased with the water $\mathrm{pH}$. In addition, an increase in water temperature favored the precipitation of Ferrihydrite, Goethite, Magnesioferrite, and Hematite. However, temperature did not favor the formation of $\mathrm{FCO}_{3}$ Aptite, Lepidocrocite, Hydroxylapatite, and Arogonite.

The Hg transport in ORR groundwater (Bear Creek Valley) was investigated using the enhanced model. The result showed that the Hg transport was influenced by ion-exchange and surface complexation with $\mathrm{Fe}(\mathrm{OH})_{3}$ and Gibbsite. The water quality at GW-923 showed that water was supersaturated with cinnabar. Thus, it was hypothesized that, at the test well, the dissolution of cinnabar became a source of $\mathrm{Hg}$. The dominant $\mathrm{Hg}$ species at GW-923 was $\mathrm{HgCl}_{2}$. This indicated that, at this well location, the Cl-ligand promoted the mobilization of $\mathrm{Hg}$. The presence of $\mathrm{Fe}(\mathrm{OH})_{3}$ and Gibbsite at wells GW363 and 369 reduced the $\mathrm{Hg}$ concentration in the solution and retarded the transport of Hg by surface complexation.

The enhanced model was employed to investigate the feasibility of using reduction in $\mathrm{Hg}$ loading as an $\mathrm{Hg}$ control strategy at EFPC. The model was used in the transport mode to assess the role of ion exchange and surface complexation in EFPC. Among other estimates, the application showed that the Hg concentration in EFPC can be reduced from $0.5 \mu \mathrm{g} / \mathrm{L}$ to about $0.08 \mu \mathrm{g} / \mathrm{L}$ within 60 years, if the $\mathrm{Hg}$ loading at the sources is reduced to $2.5 \mathrm{~g} /$ day. Furthermore, if the loading is further reduced to 0.15 $\mathrm{g} /$ day, $\mathrm{Hg}$ concentrations in the creek will reach $0.05 \mu \mathrm{g} / \mathrm{L}$ within 45 years. 


\subsection{ENP Test-Bed}

Surface waters at ENP possess flow characteristics and water quality that are quite different from the previous test bed. Here, the DOC can reach average concentrations of $31 \mathrm{mg} / \mathrm{L}$. For the surface binding with $\mathrm{Hg}(\mathrm{II})$, DOC could be defined as having two type of binding sites: weak and strong. The DOC's strong binding site is made of reduced sulfur ligand $\left(\mathrm{RS}^{-}\right)$. The strong site has a higher $\mathrm{Hg}$-DOC equilibrium constant (log $\mathrm{K}$ of 28) when compared to the weak binding site (log $\mathrm{K}$ of 10$)$. Using the enhanced model to study $\mathrm{Hg}$ species in ENP water, it was estimated that the $\mathrm{Hg}$-DOC complex dominates at all $\mathrm{pH}$ and temperature conditions. The concentration of $\mathrm{Hg}$-DOC species was ten orders of magnitude higher than other Hg-inorganic species in the ENP test-bed. It was also estimated that $\mathrm{Hg}$ immobilization at the site was influenced by peat. In SRS, Hg-Peat equilibrium constant has been reported to be as high as the Hg-DOC (Drexel et al., 2002), at concentrations of $1000 \mathrm{mg} / \mathrm{L}$ compared to $31 \mathrm{mg} / \mathrm{L}$ of DOC.

The enhanced model showed that, for typical ENP water $\mathrm{pH}$ range of 7.0-8.2, the water is saturated with Calcite, Aragonite, Dolomite and $\mathrm{Ca}\left(\mathrm{PO}_{4}\right)_{3} \mathrm{OH}$. The results were consistent with several studies which reported that those minerals are typically found in ENP water. The mineral precipitation increased with $\mathrm{pH}$ in the range of 2-10. An increase in water temperature also favored the precipitation of Calcite, Aragonite, and Dolomite, but it did not affect the precipitation of $\mathrm{Ca}\left(\mathrm{PO}_{4}\right)_{3} \mathrm{OH}$.

Results on the sensitivity of $\mathrm{Hg}$-speciation to $\mathrm{Cl}^{-}$confirmed that $\mathrm{Hg}$-speciation was strongly influenced by $\mathrm{Cl}^{-}$concentration and $\mathrm{Hg}-\mathrm{Cl}$ binding constants (i.e., log $\mathrm{K}$ ). At low salinity (i.e., low $\mathrm{Cl}^{-}$concentrations), $\mathrm{Hg}-\mathrm{Cl}$ species formation was dominated by $\mathrm{HgCl}_{2}$. For higher salinities, $\mathrm{HgCl}_{2}$ decreased and $\mathrm{HgCl}_{3}{ }^{-}$and $\mathrm{HgCl}_{4}{ }^{2-}$ increased. 
High sulfate and low DO contents in water promotes reduced sulfur that triggers the methylation of $\mathrm{Hg}$ (i.e., $\mathrm{MeHg}$ ). The enhanced model showed that in such water conditions, $\mathrm{HgHS}_{2}{ }^{-}$was a dominant species. At ENP, the waters of concern were those of the Shark River Slough (SRS) (around stations P33, P35, P36) and canal C-111 (by stations S178 and S178C), where high sulfate and low DO contents in water were found. Importantly, Harris (2011) and Harris et al. (2007) reported that high MeHg levels were found in fish and water in the slough.

The model was then applied to assess Hg transport in SRS, using the enhanced database at specific site conditions. The transport study was able to identify the roles of Hg-DOC and Hg-Peat complexes. The Hg-DOC complex was transported with the water, while $\mathrm{Hg}$ - peat was not and it settled down in the bottom. The results suggest that $27 \%$ of $\mathrm{Hg}$ (II) is expected to bind to DOC to be then transported in the SRS waters. The remaining $73 \%$ binds to peat and is most probably removed from the solution phase via settling. Trace amounts of $\mathrm{Hg}(\mathrm{II})$ were estimated to bind to inorganic ligands. In sum, the major dissolved-Hg species that moved in the slough water is predicted to be Hg-DOC complex. Importantly, the transport of $\mathrm{Hg}$-DOC in SRS is slow which can be attributed to the low velocity of the slough flow. 


\section{RECOMMENDATION FOR FURTHER STUDY}

The Hg species and their transport were studied based on average conditions in the test-beds. The assumptions used in this study are the following:

1. The models PHREEQC and PHAST are appropriate to simulate saturated flow conditions.

2. The models do not account for density-dependent flow caused by concentration gradients or temperature variations (e.g., brackish or saline environments).

3. The improvement on the ionic strength term in Debye-Hückel's expressions has been made and fitted for the major ions using chloride mean-salt activity coefficient data. This makes the models reliable at higher ionic strengths in a sodium chloride dominated system.

4. Only physical and chemical processes that affect the fate and transport of $\mathrm{Hg}$ species were recognized and analyzed. The role and effect of biological transformations as well as the photo-degradation were not included.

5. Reactions were considered at equilibrium and the kinetics of reactions were not addressed in most of the simulations. However, an exception was made in the case of testing the effect of kinetics on the sorption of $\mathrm{MeHg}$ in a Floridian aquifer setting.

6. The model solves the transport ARD equation using an explicit finite difference scheme that is forward in time and space. For each time step, the advective transport is first calculated, then all the equilibrium controlled chemical reactions, 
thereafter the dispersive transport, which is followed again by equilibrium controlled chemical reactions (Parkhurst and Appelo, 1999).

7. One major assumption in this study was that there is no interaction among chemical species, including $\mathrm{Cu}^{2+}, \mathrm{Ni}^{2+}, \mathrm{Br}^{-}$, and, $\mathrm{I}^{-}$when they are simultaneously present in the same aquatic environment. In fact, interaction (or competition) may play a very important role in the ultimate fate of $\mathrm{Hg}$ species.

8. All the simulations shown in this study were conducted under the simple assumptions made from the available site data (water composition, flow conditions and site characteristics) to study the fate and transport of $\mathrm{Hg}$ at the two test-beds. The assumptions of water condition and other site parameters were explained for each simulation made (Chapters 4-6). The assumptions may not fully represent the real site conditions which are more complex environments. However, the main purpose of this study was to demonstrate a method to enhance the coupling of geochemical and hydrological modellings of contaminants, which in this case is Hg. The assumptions made were suitable to use for this purpose and the purpose of this study was achieved. However, as a recommended future work, more complex site characteristics such as, more complex water compositions and sediments may be included in the simulations .

The following works are recommended for the future to improve the capability of the model in analyzing the $\mathrm{Hg}$ fate and transport in aquatic environments.

1. The model database may be further enhanced by including a number of minor species (e.g. $\mathrm{Cu}^{2+}, \mathrm{Ni}^{2+}, \mathrm{Br}^{-}, \mathrm{I}^{-}$, etc.), in addition to the major species (e.g., $\mathrm{Ca}^{2+}$, 
$\mathrm{Mg}^{2+}, \mathrm{Cl}^{-}$, and $\mathrm{SO}_{4}{ }^{2-}$, etc. ), which may be needed to best simulate site conditions on a case by case basis.

2. Another important area for future development is the model capability to simultaneously simulate multiple species (i.e., inorganic and organic), which may be subjected to the same chemical processes (dissolution/precipitation, ion exchange, and surface complexation, among others). This will enable the model to assess competitive effects of interest under more complex scenarios. 


\section{REFERENCES}

Adams, D.H., and Onorato G.V. (2005). "Mercury concentrations in red drum, Sciaenops ocellatus, from estuarine and offshore waters of Florida." Marine Pollution Bulletin. 50 (3): 291-300.

Ahlberg, I. (1962). "Studies on the hydrolysis of metal ions." Acta Chemica 16 (2): 887902.

AJA TECHNICAL SERVICES, INC. (1998). "Groundwater protection program calendar year 1998 evaluation of groundwater quality data for the chestnut ridge hydrogeologic regime at the U.S. Department of Energy y-12 Plant, Oak Ridge, Tennessee.” Under Subcontract No. 70Y-MVM64, Report No. Y/SUW/99$\mathrm{MVM} 64 \mathrm{~V} / 3$.

Amirbahman, A., Reid, A.L., Haines, T.A., Kahl, J.S., and Arnold, C. (2002). "Association of methylmercury with dissolved humic acids." Environmental Science \&Technology. 36 (4): 690-695.

Appelo, C.A.J., and Postma, D. (2005). "Geochemistry, Groundwater and Pollution." CRC Press Taylor \& Francis Group, Boca Raton, Florida.

Atre, S.R., and Carpenter, P.J. (2010). "Identication of cross-valley faults in the naynardville limestone Oak Ridge Reservation, Tennessee, suing seismic refraction tomography." Environmental Earth Science, 60: 1245-1256.

Arias, M., Barral, M.T., Da Silva-Carvalhal, J., Mejuto J.C., and Rubinos, D. (2004). "Interaction of $\mathrm{Hg}(\mathrm{II})$ with kaolin-humic acid complexes." Clay Minerals. 39 (1): $35-45$.

Axelrad, D.M., Lange, T., Gabriel, M., Atkeson, T.D., Pollman, C.D., Orem, W.H., Scheidt, D.J., Kalla, P.I., Frederick, P.C., and Gilmour, C.C. (2008) "South Florida Environmental Report." South Florida Water Management District.

Banks, D., Younger, P.L., and Dumpleton, S. (1996). "The historical use of mine drainage and pyrite-oxidation waters in the central and eastern England, United Kingdom.” Hydrogeology Journal. 4 (4): 55-68.

Barlow, P.M., and Reichard, E.G. (2010). "Saltwater intrusion in coastal regions of North America." Hydrogeology Journal. 18 (1): 247-260.

Bates, A.L., Orem, W.H., Harvey, J.W., and Spike, E.C. (2002) "Tracing sources of sulfur in the Florida Everglades." Journal of Environmental Quality. 31 (1): 287299. 
Bengtsson, G., and Picado, F. (2008). "Mercury sorption to sediments: Dependence on grain size, dissolved organic carbon, and suspended bacteria." Chemosphere. 73 (4): 526-531.

Benoit, J.M., Gilmour, C.C., Marson, R.P. Heyes, R., (1999). "Sulfide controls on mercury speciation and bioavailability of mercury." Applied and Environmental Microbiology.” Environmental Science \&Technology. 33: 951-957.

Benoit, J.M., Mason, R.P., Gilmour, C.C., and Aiken, G.R. (2001). "Constants for mercury binding by dissolved organic matter isolates from the Florida Everglades." Geochimica et Cosmochimica Acta. 65 (24): 4445-4451.

Bergaya, F., and Vayer, M. (1997). "CEC of clays: measurement by adsorption of a copper ethylenediamine complex.” Applied Clay Science. 12 (3): 275-280.

Black, F.J., Bruland, K.W., and Flegal, A.R. (2007). "Competing ligand exchange-solid phase extraction method for the determination of the complexation of dissolved inorganic mercury(II) in natural waters." Analytica Chimica Acta. 598 (2): 318333.

Blanco, R.I., Naja, G.M., Rivero, R.G., Price, R.M. (2013). "Spatial and temporal changes in groundwater salinity in South Florida." Applied Geochemistry. 38: 4858 .

Bloom, N.S., and Crecelius, E.A. (1983). "Determination of mercury in seawater at subnanogram per liter levels." Marine Chemistry. 14 (1): 49-59.

Brooks, S.C., and Southworth, G.R. (2011). "History of mercury use and environmental contamination at the Oak Ridge Y-12 plant." Environmental Pollution. 159 (1): 219-228.

Bruggenwert, M.G.M., and Kamphorst, A. (1979). "Survey of experimental information on cation exchange in soil systems. Developments in Soil Science. 5: 141-204.

Cai, Y., Jaffe, R., and Jones, R.D. (1999). "Interactions between dissolved organic carbon and mercury species in surface waters of the Florida everglades." Applied Geochemistry. 14 (3): 395-407.

Campbell, K., Capece, J.C., and Tremwel, T.K. (1995) "Surface/subsurface hydrology and phosphorus transport in the kissimmee river basin, Florida." Ecological Engineering, 5: 301-330.

Chattopadhyay, S., and Ickes, J. (2001). "Report on characterization and Eh/pH-based leaching tests of mercury-containing mining wastes from the sulfur bank mercury 
mine, Lake County, California." United States Environmental Protection Agency. EPA/600/R-02/032.

Choi, J., Harvey, J.W. (2000). "Quantifying time-varying groundwater discharge and recharge in wetlands: a comparison of methods in the Florida Everglades" Wetlands. 20 (3): 500-511.

Conaway, C.H., Squire, S., Mason, P.R., and Flegal A.R. (2003). "Mercury speciation in the San Francisco Bay estuary." Marine Chemistry. 80 (2-3): 199-225.

Cox, C.D., Shoesmith, M.A., and Ghosh, M.M. (1996). "Electrokinetic remediation of mercury-contaminated soils using lodine/lodide lixiviant." Environmental Science and Technology. 30: 1933-1938.

Cruz-Guzman, M., Celis, R., Hermosin, M.C., Leone, P., Negre, M., and Cornejo, J. (2003). "Sorption-desorption of lead (II) and mercury (II) by model associations of soil colloids." Soil Science Society of America Journal. 67 (5): 1378-1387.

Davis, A., Bloom, N.S., and Que-Hee, S.S. (1997). "The environmental geochemistry and bioaccessibility of mercury in soils and sediments: a review." Risk Analysis. 17 (5): 557-569.

DBHYDRO (Environmental Data), South Florida Water Management District http://www.sfwmd.gov/portal/page/portal/xwebenvironmentalmonitoring/dbhydro application. Accessed on 09/26/2011.

Depledge, M.H. (1999). "Recovery of ecosystems and their components following exposure to pollution." Journal of Aquatic Ecosystem Stress and Recovery. 6: 199-206.

Dong, W., Liang, L., Brooks, S., Southworth, G., and Gu, B. (2010). "Roles of dissolved organic matter in the speciation of mercury and methylmercury in a contaminated ecosystem in Oak Ridge, Tennessee." Environmental Chemistry. 7 (1): 94-102.

Dreier, R.B., Early, T.O., and King, H.L., (1993). "Results and interpretation of groundwater data obtained from multiport-instrumented coreholes (GW-131 through GW-135)." Fiscal years 1990 and 1991, Environmental Management Department, Oak Ridge, Tennessee.

Drexel, R.T., Haitzer, M.H., Ryan, J.N., Aiken, G.R., and Nagy, K.L. (2002). “ Mercury(II) sorption to two Florida Everglades peats: evidence for strong and weak binding and competition by dissolved organic matter released from the peat." Environmental Science Technology. 36 (19): 4058-4064. 
Driese, S.G., McKay, L.D., and Penfield, C.P. (2001) "Lithologic and pedogenic influences on porosity distribution and groundwater flow in fractured sedimentary saprolite: A new application of environmental sedimentology." Journal of Sedimentary Research, 71(5); 843-857.

Duvall, S.E., and Barron, M.G. (2000). "A Screening level probabilistic risk assessment of mercury in Florida Everglades food webs." Ecotoxicology and Environmental Safety, 47 (3): 298-305.

Dyrssen, D., Tyrell, V. (1961). "A miniarure solubility column and its application to a study of the solubility of red mercury (II) oxide in acid $3 \mathrm{M} \mathrm{NaClO}$ solutions." Acta Chemica Scandinavica. 15 (1): 1622.

Dzombak, D.A., Morel, F.M.M. (1990). "Surface complexation modeling: Hydrous ferric oxide." John Wiley \& Sons, New York.

Elliott, H.A., and Huang, C.P. (1981). "The Adsorption of $\mathrm{Cu}(\mathrm{II})$ Complexes onto Aluminosilicates." Water Research. 15(7): 849-855.

Elvado Environmental LLC. (2009) "Calendar year 2009 groundwater monitoring report" U.S. Department of Energy Y-12 National Security Complex, Oak Ridge, TN. Y/SUB/10-073231/1.

Elvado Environment LLC. (2011) "Calendar year 2011 groundwater monitoring report" U.S. Department of Energy Y-12 National Security Complex, Oak Ridge, TN. Y/SUB/12-073231/1.

Evans, D.W., and Engel, D.W. (1994). "Mercury bioaccumulation in finfish and shellfish from Lavaca Bay, Texas: descriptive models and annotated bibliography." NOAA Technical Memoris NMFSSEFSC-348: 1-89.

Evans, C.D., Monteith, D.T., and Cooper, D.M. (2005). "Long-term increases in surface water dissolved organic carbon: Observations, possible causes and environmental impacts." Environmental Pollution. 137: 55-71.

Facemire, C., Augspurger, T., Bateman, D., Brim, M., Conzelmann, P., Delchamps, S., Douglas, E., Inmon, L., Looney, K., Lopez, F., Masson, G., Morrison, D., Morse, N., and Robison, A. (1995). "Impacts of mercury contamination in the southeastern United States." Water, Air, and Soil Pollution. 80 (1-4): 923-926.

Farley, K.J., Dzombak, D.A., and Morel, F.M.M. (1984). "A surface precipitation model for the sorption of cations on metal oxides." Journal of Colloid and Interface Science. 106 (1): 226-242. 
Feng, X., Jiang, H., Qiu, G., Yan, H., Li, G., and Li, Z. (2009). "Geochemical processes of mercury in Wujianddu and Dongfeng reservoirs, Guizhou, China." Environmental Pollution. 157(11): 2970-2984.

Florida coastal everglades long term ecological research website. "www. Fcelter.fiu.edu" Accessed on 01/10/2011.

Gårdfeldt, K., Munthe, J., StrÖmberget, D., and Lindqvist, O. (2003). "A kinetic study on the abiotic methylation of divalent mercury in the aqueous phase." The Science of the Total Environment. 304 (1-3): 127-136.

Gårdfeldt, K., Sommar, J., StrÖmberg, D., and Feng, X. (2001) "Oxidation of atomic mercury by hydroxyl radicals and photoinduced decomposition of methylmercury in the aqueous phase." Atmosphere Environment. 35(17): 3039-3047.

Garett, A., and Hirschler, A. (1938). "The solubilities of red and yellow mercuric oxides in water, in alkali, and in alkaline salt solutions. The acid and basic dissociation constants of mercuric hydroxide." Journal of American Chemical Society. 60 (2): 299-306.

GEMS, GEM-Selektor Geochemical Software http://gems.web.psi.ch/overview.html. Accessed on 11/02/2011

Grassi, S., and Netti, R. (2002). "Sea water intrusion and mercury pollution of some coastal aquifers in the province of Grosseto (Southern Tuscany-Italy)." Journal of Hydrology. 237 (3-4): 198-211.

Guentzel, J.L., Landing, W.M., Gill, G.A., and Pollman, C.D. (2001). "Processes influencing rainfall deposition of mercury in Florida." Environmental Sciences \& Technology, 35 (5): 863-873.

Haitzer, M., Aiken, G.R., and Ryan, J.N. (2002). "Binding of mercury (II) to dissolved organic matter: the role of the mercury-to-DOM concentration ratio." Environmental Sciences \& Technology. 36 (16): 3564-3570.

Haitzer, M., Aiken, G.R., and Ryan, J.N. (2003). "Binding of mercury(II) to aquatic humic substances: influence of $\mathrm{pH}$ and source of humic substances." Environmental Sciences \& Technology. 37 (11): 2436-2441.

Halim, C.E., Stephen, S.E., Scott, J.A., Amal, R., and Low, G. (2005). "Modelling the leaching of $\mathrm{Pb}, \mathrm{Cd}$, As, and $\mathrm{Cr}$ from cementitious waste using PHREEQC." Journal of Hazardous Materials. 125 (1-3): 45-61. 
Han, F.X., Su, Y., Shi, Z., Xia, Y., Tian, W., Philips, V., Monts, D.L., Gu, M., and Liang, Y. (2012) "Mercury distribution and speciation in floodplain soils and uptake into native earthworms." Geogerma. 170: 261-268.

Han, S.H., and Gill, G.A. (2005). "Determination of mercury complexation in coastal and estuarine waters using competitive ligand exchange method." Environmental Sciences \& Technology. 39 (17): 6607-6615.

Harmon, S.M., King, J.K., Gladden, J.B., Chandler, G.T., and Newman, L.A. (2004). "Methylmercury Formation in a wetland mesocosm amended with sulfate." Environmental Sciences \& Technology. 38 (2): 650-656.

Harris, W. (2011). Mineral distribution and weathering in the greater everglades: implications for restoration." Environmental Sciences \& Technology. 41 (2): 427.

Harris, W.G., Fisher, M.M., Cao, X., Osborne, T., and Ellis, L. (2007). "Magnesium-rich minerals in sediment and suspended particulates of south florida water bodies: implications for turbidity." Journal of Environmental Quality. 36 (6): 1670-1677.

Harvey, J.W., Choi, J., and Mooney, R.H. (2000) "Hydrologic interactions between surface water and ground water in Taylor Slough, Everglades National Park," U.S. Geological Survey open-file report 00-449.

Harvey, J.W., Krupa, S.L., Gefvert, C., Mooney, R.H., Choi, J., King, S.A., and Giddings, J.B., (2002). "Interactions between surface water and ground water and effects on mercury transport in the north-central Everglades." U.S. Geological Survey Water-Resources Investigations Report, 02-4050:1- 82.

Harvey, J.W., Newlin, J.T., and Krupa, S.L. (2005). "Modeling decadal timescale interactions between surface water and ground water in the central Everglades, Florida, USA." Journal of Hydrology. 320 (2006): 400-420.

Hayes, K.F., and Leckie, J.O. (1986). "In geochemical processes at mineral surfaces.” in: Davis, J.A., Hayes, K.F. (Eds.). American Chemical Society, Washington, DC. 323:115-141.

Hietanen, S., Hogfeldt, E. (1976). "On the hydrolysis of $\mathrm{Hg}(\mathrm{I})$ perchlorate in $3 \mathrm{M}(\mathrm{Na}) \mathrm{ClO}_{4}$." Chemica Scripta 10 (2): 41-44.

Hill, W.R., Mulholland, P.J., and Marzolf, E.R. (2001). "Stream ecosystem responses to forest leaf emergence in spring." Ecology. 82:2306-2319. 
Hill, W.R., Ryon, M.G., Smith, J.G., Adams A.M., Boston, H.L., and Stewart, A.J. (2010). "The role of Periphyton in mediating the effect of pollution in a stream ecosystem." Environmental Management. 45 (3): 563-576.

Hintelmann, H., Welbourn, P.M., and Evans R.D. (1997). "Measurement of complexation of methylmercury compounds by freshwater humic substances using equilibrium dialysis." Environmental Sciences \& Technology. 31 (2): 489-495.

Hurley, J.P., Kranbbenhoft, D.P., Babiarz, C.L., Andren, A.W. (1994). "Cycling of mercury across sediment-water interface in seepage lake. In: Baker, L.A. (Ed.), Environmental chemistry of lakes and reservoirs.” American Chemical Society, Washington, DC. 425-449.

Hurley, J.P., Kranbbenhoft, D.P., Cleckner, L.B., Olson, M.L. Aiken, G.R., Rawlik Jr., P.S. (1998). "System sontrols on the aqueous distribution of mercury in the northern Florida Everglades.” Biogeochemistry. 40 (2-3): 293-311.

Jago, W.K., Loffman, R.S., Motley, C.A. (1995). "Chapter 7: Groundwater." Annual report, Oak Ridge National Laboratory, Oak Ridge, Tennessee.

Jay J.A., Morel F.M.M. and Hemond, H.F. (2000). "Mercury speciation in the presence of polysulfides." Environmental Sciences \& Technology. 34 (11): 2196-2200.

Jeremiason, J.D., Engstrom, D.R., Swain, E.B., Nater, E.A., Johnson, B.M., Almendinger, J.E., Monson, B.A., and Kolka, R.K. (2006). "Sulfate addition increases methylmercury production in an experimental wetland." Environmental Sciences \& Technology. 40 (12): 3800-3806.

Karlsson, T., and Skyllberg, U. (2003). "Bonding of ppb levels of methyl mercury to reduced sulfur groups in soil organic matter." Environmental Sciences \& Technology. 37 (21): 4912-4918.

KBN Engineering and Applied Sciences (KBN). (1992). "Mercury emissions to the atmosphere in Florida." Prepared for the Florida Department of Environmental Regulation, Tallahassee.

Kelkar, S., Roback, R., Robinson, B., Srinivasan, G., Jones, C., Reimus, P. (2006). "Saturated Zone Plume in Volcanic Rock: Implications for Yucca Mountain." Technical Information Center Oak Ridge Tennessee, DE2006-893920.

Khan, A.A., and Alam, M.M. (2004). "New and novel organic-iorganic type crystalline 'polypyrrolel/polyantimonic acid' composite system: preparation, characterization and analytical applications as a cation-exchange material and $\mathrm{Hg}$ (II) ion-selective membrane electrode." Analytica Chimica Acta. 504 (2): 253-264. 
Kim, C.S., Rytuba, J.J., Brown, G.E. (2004) "EXAFS study of mercury (II) sorption to Fe-Al-(hydro)oxides: II. Effects of chloride and sulfate." Journal of Colloid and Interface Science. 270(1): 9-20.

Krupa, S., Hill, S., and Bevier, C. (2001). "Miami-Dade County Northwest Wellfield Groundwater Velocity Investigation." Technical Publication WS-1, South Florida Water Management District.

Lamborg, C.H., Tseng, C.M., Fitzgerald, W.F., Balcom, P.H., and Hammerschmidt, C.R. (2003) "Determination of the mercury complexation characteristics of dissolved organic matter in natural water with reducible $\mathrm{Hg}$ titrations." Environmental Sciences \& Technology. 37 (15): 3316-3322.

Leonard, L., Croft, A., Childers, D., Mitchell-Bruker, S., Solo-Gabriele, H., and Ross, M., (2006). "Characteristics of surface-water flows in the ridge and slough landscape of Everglades National Park: implications for particulate transport." Hydrobiologia. 569 (1): 5-22.

Li, Y., Mao, Y., Liu, G., Tachiev, G., Roelant, D., Feng, X., and Cai, Y. (2010). "Degradation of methylmercury and its effects on mercury distribution and cycling in the Florida everglades." Environmental Sciences \& Technology. 44 (17): 6661-6666.

Liang, P., Li, Y., Zhang, C., Wu, S., Cui, H., Yu, S., and Wong, M.H. (2013). "Effects of salinity and humic acid on the sorption of $\mathrm{Hg}$ on Fe and Mn hydroxides." Journal of Hazardous Materials. 244-245: 322-328.

Libich, S., and Robenstein, D. (1973). "Nuclear magnetic resonance studies of the solution chemistry of metal complexes." Analytical Chemistry. 45 (1): 118-124.

Little, M.E. (2006). "Distribution of arsenic and mercury in terrestrial and marine environments impacted by gold mine tailings, Wine Harbour, Nova Scotia." Dalhousie University, Halifax, Nova Scotia. 161 pages.

Loar, J.M., Stewart, A.J., and Smith, J.G. (2011). "Twenty-five years of ecological recovery of East Fork Poplar Creek: Review of environmental problems and remedial actions." Environmental Management. 47 (6): 1010-1020.

Loren, G.H., and Olofsson, G. (1975). "Mercury: Thermodynamic Properties, chemical equilibia, and standard potentials." Chemical Reviews. 75 (5): 585-602.

Lui, G., Cai, Y., Philippi, T., Kalla, P., Scheidt, D., Richards, J., Scinto, L., and Appleby, C. (2008). "Distribution of total and methylmercury in different ecosystem compartments in the Everglades: Implications for mercury bioaccumulation." Environmental Pollution. 153 (2): 257-265. 
Mackay, D., Wania, F., and Schroeder, W.H. (1995). "Prospects for modeling the behavior and fate of mercury, globally and in aquatic systems." Water, Air, and Soil Pollution. 80: 941-950.

Magos, L., and Clarkson, T.W. (2006). "Overview of the clinical toxicity of mercury." Annals of clinical biochemistry. 43 (4): 257-268.

Margaritz, M., Goldenberg, L., Kafri, U., and Arad, A. (1980). "Dolomite formation in the seawater-freshwater interface." Nature, 287 (1): 622-624.

Martell, A.E., and Smith R.M. (2001). "NIST critically selected stability constants of metal complexes, version 6 Gaithersburg." National Institute of Standards and Technology, Maryland.

Matsuyama, A., Eguchi, T., Sonoda, I., Tada, A., Yano, S., Tai, A., Marumoto, K., Tomiyasu, T., and Akagi, H. (2011). "Mercury speciation in the water of Minamata Bay, Japan.” Water Air and Soil Pollution. 218: 399-412.

Meng, X.G., and Letterman, R.D. (1993). "Effect of component oxide interaction on the adsorption properties of mixed oxides." Environmental Science Technology. 27 (5); 970-975.

MINEQL+, Geochemical Software. www.mineql.com. Accessed on 11/02/2011.

MINTEQA2, Geochemical Software. http://www.epa.gov/ceampub/mmedia/minteq/. Accessed on 11/01/2011.

Miretzky, P., Bisinoti, M.C., and Jardim W.F. (2005). "Sorption of mercury (II) in Amazon soils from column studies." Chemosphere. 60 (11):1583-1589.

Morel, F.M.M., and Hering, J.G. (1993). "Principles and applications of aquatic chemistry." John Wiley \& Sons, Inc.

Nativ, R., Halleran, A., and Hunley, A. (1997). "Evidence for ground-water circulation in the brine-filled aquitard, Oak Ridge, Tennessee." Ground Water. 35 (4): 647-656.

Oak Ridge National Laboratory Website: www.esd.ornl.gov. Access on 01/12/2012.

OREIS (Oak Ridge Environmental Information System) http://wwworeis.ettp.energy.gov.

Osborne, T.Z., Bruland, G.L., Newman, S., Reddy, K.R., and Grunwald, S. (2011). "Spatial distributions and eco-partitioning of soil biogeochemical properties in the 
Everglades National Park.” Environmental Monitoring Assessment. 183 (1-4): 395-408.

Pacyna, E.G., and Pacyna, J.M. (2002). "Global emission of mercury from anthropogenic sources in 1995." Water, Air, and Soil Pollution. 137 (1-4): 149-165.

Parkhurst, D.L., (1995). "User's guide to PHREEQC a computer program for speciation, reaction path, advective transport, and inverse geochemical calculation." US Geological Survey Water Resource Investigations Report, 95-4227: 1-143.

Parkhurst, D.L., and Appelo, C.AJ. (1999) "User's guide to PHREEQC (version 2)-A computer program for speciation, batch-reaction, one-dimensional transport, and inverse geochemical calculations." U.S. Geological Survey water-resources investigations report: 1-312.

Parkhurst, D.L., Kipp, K.L., and Charlton, S.R. (2010). "PHAST version 2-a program for simulating groundwater flow, solute transport, and multicomponent geochemical reactions." U.S. Department if the Interior and U.S. Geological Survey, 1-235.

Pichler, T., Price, R., Lazareva, O., and Dippold, A. (2011) "Determination of arsenic concentration and distribution in the Floridan Aquifer System" Journal of Geochemical Exploration, 111: 84-96.

Plummer, L.N., and Sprinkle, C.L. (2001) "Radiocarbon dating of dissolved inorganic carbon in groundwater confined parts of the Upper Floridan aquifer, Florida, USA.” Hydrogeology Journal. 9 (2): 127-150.

Plummer, L.N., Busby, J.F., Lee, R.W., and Hanshaw, B.B. (1990) "Geochemical modeling of the Madison aquifer in parts of Montana, Wyoming and South Dakota." Water Resources Research. 26 (9): 1981-2014.

Powell K.J., Brown P.L., Byrne R.H., Gajda T., Hefter G., Sjoberg S., and Wanner H. (2005). "Chemical speciation of environmentally significant heavy metals with inorganic ligands. Part 1: The $\mathrm{Hg}^{2+}-\mathrm{Cl}^{-}, \mathrm{OH}^{-}, \mathrm{CO}_{3}{ }^{2-}, \mathrm{SO}_{4}{ }^{2-}$, and $\mathrm{PO}_{4}{ }^{2-}$ aqueous systems." Pure and Applied Chemistry. 77 (4): 739-800.

Price, R.M., Swart, P.K., and Fourqurean, J.W. (2006). "Coastal groundwater discharge an additional source of phosphorus for the oligotrophic wetlands of the Everglades." Hydrobiologia. 569 (1): 23-36.

Price, R.M., Top, Z., Happell, J.D., and Swart, P.K. (2003). "Use of tritium and helium to define groundwater flow conditions in Everglades National Park." Water Resources Research. 39 (9): 1267-1280. 
Pulido-Leboeuf, P. (2004). "Seawater intrusion and associated process in small coastal complex aquifer (Castell de Ferro, Spain).” Applied Geochemistry. 19 (10): 15171527.

Qian, J., Skyllberg, U., Frech, W., Bleam, W.F., Bloom, P.R., and Petit, P.E. (2002). "Bonding of methyl mercury to reduced sulfur groups in soil and stream organic matter as determined by X-ray absorption spectroscopy and binding affinity studies." Geochimica et Cosmochimica Acta. 66 (22): 3873- 3885.

Quarfort-Dahlman, I. (1975). “On some phosphate equilibria.” Chemica Scripta. 8 (2): 112-125.

Ravichandran, M. (2004). "Interactions between mercury and dissolved organic matter." Chemosphere. 55 (3): 319-331.

Reddy, M., and Aiken, G.R. (2001). "Fulvic acid-sulfide ion competition for mercury ion binding in the Florida Everglades." Water, Air, and Soil Pollution. 132 (1-2): 89104.

Riese, A.C. (1982). "Adsorption of radium and thorium onto quartz and kaolinite, a comparison of solution surface equilibria models." Doctoral thesis, Colorado School of Mines, Golden, Colorado, $210 \mathrm{pp}$.

Samborska, K., and Halas, S. (2010). " 34 S and 180 in dissolved sulfate as tracers of hydrogeochemical evolution of the triassic carbonate aquifer exposed to intense groundwater exploitation (Olkusz-Zawiercie region, southern Poland)." Applied Geochemistry. 25 (9): 1397-1414.

Sarkar, D., Essington, M.E., and Misra, K.C. (1999). "Adsorption of mercury(II) by variable charge surfaces of quartz and gibbsite." Soil Science Society of America Journal. 63 (6); 1626-1636.

Sarkar, D., Essington, M.E., and Misra, K.C. (2000). "Adsorption of mercury(II) by kaolinite.” Soil Science Society of America Journal. 64 (6): 1968-1975.

Schlüter, K. (1995). "Sorption of inorganic mercury and monomethyl mercury in an ironhumus podzol soil of southern Norway studied by batch experiments." Environmental Geology. 30 (3-4):266-279.

Schlüter, K., and Gäth, S. (1997). "Modelling leaching of inorganic $\operatorname{Hg}($ II) in a Scandinavian iron-humus podzol-volidation and long-term leaching under various deposition rates." Water, Air, and Soil Pollution, 96 (1-4): 301-320.

Schulze-Makuch, D. (200. "Longitudinal dispersivity data and implications for scaling behavior.”. Ground Water, 43(3):443-457. 
Schwarzenbach, G., and Schellenberg, M. (1965). "The chemistry of methylmercurycomplexes." Helvetica Chimica Acta. 48 (1): 28-46.

Shen, C., Niu, J., Anderson, E.J., and Phanikumar, M.S. (2010). "Estimating longitudinal dispersion in rivers using acoustic doppler current profilers." Advances in Water Resources, 33: 615-623.

Sigel, A., and Sigel, H. (1997). "Metal ions in biological systems: mercury and its effects on environment and biology." CRC press. 648 pages.

Singh, S.P.N., and Mattigod, S.V. (1992). "Modeling boron adsorption on kaolinite." Clays and Clay Minerals. 40 (2): 192-205.

Skyllberg, U., Bloom, P.R., Qian, J., Lin, C.M., Bleam, W.F. (2006). "Complexation of mercury(II) in soil organic matter: EXAFS evidence for linear two-coordination with reduced sulfur groups." Environmental Sciences Technology. 40 (13): 41744180 .

Southworth, G.R., and Brooks, S.C. (2011). "History of mercury use and environmental contamination at the Oak Ridge Y-12 Plant." Environmental Pollution. 159 (1): 219-228.

Southworth, G.R., Turner, R.R., Peterson, M.J., and Bogle, M.A. (1995). "Form of mercury in steam fish exposed to high concentrations of dissolved inorganic mercury" Chemosphere. 30 (4): 779-787.

Southworth, G.R., Turner, R.R., Peterson, M.J., Bogle, M.A., and Ryon, M.G. (1999). "Response of mercury contamination in fish to decreased aqueous concentrations and loading of inorganic mercury in a small stream." Environmental Monitoring and Assessment. 63 (3): 481-494.

Stafford, P., Toran, L., McKay, L. (1998). "Influence of fracture truncation on dispersion: A dual permeability model." Journal of Contamination Hydrology. 30: 79-100.

Stewart, A.J., Haynes G.J., and Martinez, M.I. (2009). "Fate and biological effects of contaminated vegetation in Tennessee stream." Environmental Toxicology and Chemistry. 11 (5): 653-664.

Stewart, A.J., Smith, J.G., and Loar, J.M. (2011). "Long-term water-quality changes in East Fork Poplar Creek, Tennessee: Background, trends, and potential biological consequences." Environmental Management. 47: 1021-1032. 
Stoessell, R.K., Ward, W.C., and Schuffert, J.D. (1989). "Water chemistry and CaCO3 dissolution in the saline part of an open-flow mixing zone coastal Yucatan Peninsula, Mexico." Geological Society of America Bulletin. 101 (1): 159-169.

Stumm, W., and Morgan, J. J. (1996). "Aquatic chemistry: Chemical equilibria and rates in natural waters." (3rd ed.), A Wiley-Interscience publication, New York.

Stumm, W., and Morgan, J.J. (1981). "Aquatic Chemistry. An introduction emphasizing chemical equilibria in natural water." (2nd ed.), Wiley, New York: 1-780.

Tibbals, C.H. (1990). "Hydrology of the Floridan aquifer system in east-central Florida." United States Geological Survey, Professional Paper; (USA), 1403E.

Tiruta-Barna, L. (2008). "Using PHREEQC for modelling and simulation of dynamic leaching tests and scenarios." Journal of Hazardous Materials. 157 (2-3): 525-533.

Toran, L.E., and Saunders, J.A. (1999). "Modeling alternative paths of chemical evolution of Na-HCO3 - type groundwater near Oak Ridge, Tennessee, USA." Hydrogeology. 7 (4): 355-364.

Tsuda, T., Yorifuji, T., Takao, S., Miyai, M., and Babazono, A. (2009). "Minamata disease: Catastrophic poisoning due to a failed public health response." Journal of Public Health Policy. 30 (1): 54-67.

U.S. Geology Survey, PHREEQC Software version 2 http://wwwbrr.cr.usgs.gov/projects/GWC_coupled/phreeqc/index.html Accessed on $02 / 10 / 2011$.

Vasquez, J. (2008). "Chemical reduction/volatilization to remove mercury from East Fork Poplar Creek (EFPC).” Student Summer Internship Technical Report for U.S. Department of Energy, Office of Environmental Management under Contract No. DE-FG01-05EW07033.

Vertacnik, A., Prohic, E., Juracic, M.,Barisic, D., and Lulic, S. (1997). "Selected element concentrations in alluvial sediments under garbage disposal site (Zagreb, Croatia)." Water Resources. 31 (6): 1421-1429.

Visual MINTEQ, Geochemical Software www2.lwr.kth.se/English/OurSoftware/vminteq/. Accessed on 11/01/2011.

Walton Jr, T.L. (2007). "Projected sea level rise in Florida." Ocean Engineering. 34: 1832-1840. 
Wang, H., Waldon, M.G., Meselhe, E.A., Arceneaux, J.C., Chen, C., and Harwell, M.C. (2009). "Surface water sulfate dynamics in the northern Florida Everglades." Journal of Environmental Quality. 38 (2): 734-741.

Wang, J.S., Huang, P.M., Liaw, W.K., and Hammer, U.T. (1991). "Kinetics of the desorption of mercury form selected freshwater sediments as influenced by chloride." Water, Air, and Soil Pollution. 56 (1): 533-542.

Wang, Q., Kim, D., Dionysiou, D.D., Sorial, G.A., and Timberlake, D. (2004). "Sources and remediation for mercury contamination in aquatic systems - a literature review." Environmental pollution. 131 (2): 323-336.

Watanabe, A., Moroi, K., Sato, H., Tsutsuki, K., Maie, N., Melling, L., and Jaffé, R. (2012). "Contributions of humic substances to the dissolved organic carbon pool in wetlands from different climates." Chemosphere. 88: 1265-1268.

Weaver, K., Payne, G., and Xue, S. K. (2008). "Chapter 3A: Status of water quality in the Everglades protection area, 2008 South Florida environmental report." South Florida Water Manage District, West Palm, FL.

Weerasooriya, R., Tobschall, H.J., Seneviratne, W., and Bandara, A. (2007). "Transition stante kinetics of $\mathrm{Hg}(\mathrm{II})$ adsorption at gibbsite-water interface." Journal of Hazardous Materials. 147(3): 971-978.

Wnalin, L., Kim, E., and Mason, R. (2007). "Factor influencing the oxidation, reduction, methylation and demethylation of mercury species in coastal waters." Marine Chemistry. 107 (3): 278-294.

Xia, K., Skyllberg, U.L., Bleam, W.F., Bloom, P.R., Nater, E.A., and Helmke, P.A. (1999). "X-ray absorption spectroscopic evidence for the complexation of $\mathrm{Hg}$ (II) by reduced sulfur in soil organic matter." Environmental Science \& Technology. 33 (2): $257-261$.

Yasunaga, T., and Ikeda, T. (1986). "In geochemical processes at mineral surfaces." in: Davis, J.A., Hayes, K.F. (Eds.). American Chemical Society, Washington, DC. 323: 231-253.

Yin, Y., Allen, H.E., and Huang, C.P. (1997). "Kinetics of mercury(II) adsorption and desorption on soil." Environmental Sciences Technology. 31 (2): 496-503.

Zachara, J.M., Cowan, C.E., Schmidt, R.L., and Ainsworth, C.C. (1988). "Chromate adsorption by kaolinite." Clays and Clay Minerals. 36 (4): 317-326.

Zahir, F., Rizwi S.J., Haq, S.K., and Khanb, R.H. (2005). "Low dose mercury toxicity and human health." Environmental Toxicology and Pharmacology. 20: 351-360. 
Zhong, H., and Wang, W. (2009). "Inorganic mercury binding with different sulfur species in anoxic sediments and their gut juice extractions." Environmental Toxicology and Chemistry. 28 (9): 1851-1857.

Zhu, C. (2002). "Estimation of surface precipitation constants for sorption of divalent metals onto hydrous ferric oxide and calcite." Chemical Geology. 188 (1-2): 2332.

Zhu, Y., Ma, L.Q., Gao, B., Bonzongo, J.C., Harris, W., and Gu, B. (2012). Transport and interactions of kaolinite and mercury in saturated sand media." Journal of Hazardous Materials. 213-214: 93-99. 
APPENDICES 


\section{APPENDIX A}

\section{PHREEQC Capabilities and Limitation}

[Quoted from Parkhurst, D. L. and C. A. J. Appelo, User's Guide to PHREEQC

(Version 2), U.S. Geological Survey, U.S. DOI, Denver, CO (1999)]

PHREEQC version 2 is a computer program for simulating chemical reactions and transport processes in natural or polluted waters. The program is based on equilibrium chemistry of aqueous solutions interacting with minerals, gases, solid solutions, exchangers, and sorption surfaces, but also includes the capability to model kinetic reactions with rate equations that are completely user-specified in the form of basic statements. Kinetic and equilibrium reactants can be interconnected, for example by linking the number of surface sites to the amount of a kinetic reactant that is consumed (or produced) during the course of a model period. A 1D transport algorithm comprises dispersion, diffusion, and various options for dual porosity media. A powerful inverse modeling capability allows identification of reactions that account for observed water compositions along a flowline or in the time course of an experiment. A chemical data base allows application of the reaction, transport, and inverse-modeling capabilities to chemical reactions that are recognized as influencing rain, soil, ground and surface water quality.

PHREEQC is based on the FORTRAN program PHREEQE (Parkhurst and others, 1980). PHREEQE was capable of simulating a variety of geochemical reactions for a system including mixing of waters, addition of net irreversible reactions to solution, 
dissolving and precipitating phases to achieve equilibrium with the aqueous phase, and effects of changing temperature.

PHREEQE calculated concentrations of elements, molalities and activities of aqueous species, $\mathrm{pH}$, pe, saturation indices, and mole transfers of phases to achieve equilibrium as a function of specified reversible and irreversible geochemical reactions. PHREEQC version 1 (Parkhurst, 1995) was a completely new program written in the C programming language that implemented all of the capabilities of PHREEQE and added many capabilities that were not available in PHREEQE, including ion-exchange equilibria, surface-complexation equilibria, fixed-pressure gas-phase equilibria, and advective transport. Other improvements relative to PHREEQE included complete accounting for elements in solids and the aqueous and gas phase, mole balance on hydrogen and oxygen to account for the mass of water in the aqueous phase, identification of the stable phase assemblage from a list of candidate phases, use of redox couples for definition of redox state in speciation calculations, and a more robust nonlinear equation solver.

PHREEQC version 2 is a modification of PHREEQC version 1. All of the capabilities and most of the code for version 1 are retained in version 2 and several new capabilities have been added, including kinetically controlled reactions, solid-solution equilibria, fixed-volume gas-phase equilibria, variation of the number of exchange or surface sites in proportion to a mineral or kinetic reactant, diffusion or dispersion in 1D transport, 1D transport coupled with diffusion into stagnant zones, and isotope mole balance in inverse modeling. The numerical method has been modified to use several sets of convergence parameters in an attempt to avoid convergence problems. User-defined 
quantities can be written to the primary output file and (or) to a file suitable for importation into a spreadsheet, and solution compositions can be defined in a format that is more compatible with spreadsheet programs.

Beyond PHREEQC capabilities, it must be acknowledged that the model also has limitations that define the extent of its application and result in uncertainties. Limitations include for example the expressions used to account for non-ideality of aqueous solutions, consistency of databases, models defining ion exchange, surface complexation, solid solution activities, numerical dispersion, and convergence in transport modeling, among others. 


\section{APPENDIX B}

PHAST Capabilities and Limitation

[Quoted from Parkhurst, D.L., Kipp, K.L., and Charlton, S.R., 2010, PHAST

Version 2-A program for simulating groundwater flow, solute transport, and

multicomponent geochemical reactions: U.S. Geological Survey Techniques and

Methods 6-A35, 235 p.]

The computer program PHAST (PHREEQC And HST3D) simulates multicomponent, reactive solute transport in three-dimensional saturated groundwater flow systems. PHAST is a versatile groundwater flow and solute-transport simulator with capabilities to model a wide range of equilibrium and kinetic geochemical reactions. The flow and transport calculations are based on a modified version of HST3D that is restricted to constant fluid density and constant temperature. The geochemical reactions are simulated with the geochemical model PHREEQC, which is embedded in PHAST. Major enhancements in PHAST Version 2 allow spatial data to be defined in a combination of map and grid coordinate systems, independent of a specific model grid (without node-by-node input). At run time, aquifer properties are interpolated from the spatial data to the model grid; regridding requires only redefinition of the grid without modification of the spatial data. PHAST is applicable to the study of natural and contaminated groundwater systems at a variety of scales ranging from laboratory experiments to local and regional field scales. PHAST can be used in studies of migration of nutrients, inorganic and organic contaminants, and radionuclides; in projects such as aquifer storage and recovery or engineered remediation; and in investigations of the natural rock/water interactions in aquifers. PHAST is not appropriate for unsaturated- 
zone flow, multiphase flow, or density-dependent flow. A variety of boundary conditions are available in PHAST to simulate flow and transport, including specified-head, flux (specified-flux), and leaky (head-dependent) conditions, as well as the special cases of rivers, drains, and wells. Chemical reactions in PHAST include (1) homogeneous equilibria using an ion-association or Pitzer specific interaction thermodynamic model; (2) heterogeneous equilibria between the aqueous solution and minerals, ion exchange sites, surface complexation sites, solid solutions, and gases; and (3) kinetic reactions with rates that are a function of solution composition. The aqueous model (elements, chemical reactions, and equilibrium constants), minerals, exchangers, surfaces, gases, kinetic reactants, and rate expressions may be defined or modified by the modeler. The PHAST simulator may require large amounts of memory and long Central Processing Unit (CPU) times. To reduce the long CPU times, a parallel version of PHAST has been developed that runs on a multiprocessor computer or on a collection of computers that are networked. The parallel version requires Message Passing Interface, which is freely available. The parallel version is effective in reducing simulation times. PHAST requires three input files. Only the flow and transport file is described in detail in this report. The other two files, the chemistry data file and the database file, are identical to PHREEQC files, and a detailed description of these files is in the PHREEQC documentation. PHAST Version 2 has a number of enhancements to allow simpler definition of spatial information and to avoid grid-dependent (node-by-node) input definitions. Formerly, all spatial data were defined with rectangular zones. Now wedge-shaped and irregularly shaped volumes may be used to specify the hydrologic and chemical properties of regions within the model domain. Spatial data can be imported from ArcInfo shape and ASCII 
raster files and from a simple $\mathrm{X}, \mathrm{Y}, \mathrm{Z}$ file format. To accommodate a grid that is not aligned with the coordinate system of the imported files, it is possible to define features in map and grid coordinate systems within the same input file.

New capabilities have been added to interpolate spatial data to the two- or threedimensional locations of cells and elements. Two-dimensional interpolation is used to define surfaces for the tops and bottoms of three-dimensional regions within the model domain. Surfaces are created by two-dimensional interpolation of scattered X, Y points with associated elevation data. Within the bounds of the scattered points (the convex hull), natural neighbor interpolation is implemented, which uses an area weighting scheme to assign an elevation to a target point based on elevations at the nearest of the scattered points; outside the convex hull, the elevation of the closest point is assigned to a target point. A new capability has been added to aggregate flows of water and solute into an arbitrarily shaped region and through the boundary-condition cells included in the region. Any number of flow aggregation regions may be defined. These regions need not be mutually exclusive, and regions can be combined to define larger, possibly noncontiguous regions. A facility exists to save heads as a function of time and space for these regions, which then can be used to specify boundary-condition heads in a subsequent run. 


\section{APPENDIX C}

Hg-speciation thermodynamic data for PHREEQC model database is shown in Tables C 1, C 2 and C 3. The exchange coefficients related to $\mathrm{Hg}(\mathrm{II})$ and the sorption coefficient of $\mathrm{Hg}$ on the surface of minerals are shown in Table $\mathrm{C} 4$ and $\mathrm{C} 5$ respectively.

Table C $1 \mathrm{Hg}$ species thermodynamic reaction constant added to PHREEQC model

\begin{tabular}{|c|c|c|c|}
\hline Hg species & Reactions & $\log K$ & Ref. \\
\hline $\mathrm{HgHPO}_{4}$ & $\mathrm{Hg}(\mathrm{OH})_{2}+\mathrm{HPO}_{4}{ }^{2-}+2 \mathrm{H}^{+}=\mathrm{HgHPO}_{4}+2 \mathrm{H}_{2} \mathrm{O}$ & 14.99 & Powell et al. (2005) \\
\hline $\mathrm{HgPO}_{4}^{-}$ & $\mathrm{Hg}(\mathrm{OH})_{2}+\mathrm{HPO}_{4}^{2-}+\mathrm{H}^{+}=\mathrm{HgPO}_{4}^{-}+2 \mathrm{H}_{2} \mathrm{O}$ & 9.44 & Powell et al. (2005) \\
\hline $\mathrm{HgCO}_{3}$ & $\mathrm{Hg}(\mathrm{OH})_{2}+\mathrm{CO}_{3}{ }^{2-}+2 \mathrm{H}^{+}=\mathrm{HgCO}_{3}+2 \mathrm{H}_{2} \mathrm{O}$ & 17.70 & Powell et al. (2005) \\
\hline $\mathrm{Hg}(\mathrm{OH}) \mathrm{CO}_{3}^{-}$ & $\mathrm{Hg}(\mathrm{OH})_{2}+\mathrm{OH}-+\mathrm{CO}_{3}^{2-}+2 \mathrm{H}^{+}=\mathrm{Hg}(\mathrm{OH}) \mathrm{CO}_{3}^{-}+2 \mathrm{H}_{2} \mathrm{O}$ & 25.53 & Powell et al. (2005) \\
\hline $\mathrm{HgHCO}_{3}^{+}$ & $\mathrm{Hg}(\mathrm{OH})_{2}+3 \mathrm{H}^{+}+\mathrm{CO}_{3}{ }^{2-}=\mathrm{HgHCO}_{3}^{+}+2 \mathrm{H}_{2} \mathrm{O}$ & 22.03 & Powell et al. (2005) \\
\hline $\mathrm{HgS}_{2} \mathrm{H}^{-}$ & $\mathrm{Hg}(\mathrm{OH})_{2}+2 \mathrm{HS}^{-}+\mathrm{OH}^{-}+2 \mathrm{H}^{+}=\mathrm{HgS}_{2} \mathrm{H}^{-}+3 \mathrm{H}_{2} \mathrm{O}$ & 54.79 & $\begin{array}{c}\text { Hurley et al. (1994) } \\
\text { and Benoit et al. } \\
(1999)\end{array}$ \\
\hline$\left[\mathrm{Hg}\left(\mathrm{CH}_{3} \mathrm{COO}\right)\right]^{+}$ & $\mathrm{Hg}(\mathrm{OH})_{2}+\mathrm{CH}_{3} \mathrm{COO}^{-}+2 \mathrm{H}^{+}=\left[\mathrm{Hg}\left(\mathrm{CH}_{3} \mathrm{COO}\right)\right]^{+}+2 \mathrm{H}_{2} \mathrm{O}$ & 10.49 & Gårdfeldt et al. (2003) \\
\hline $\mathrm{Hg}\left(\mathrm{CH}_{3} \mathrm{COO}\right)_{2}$ & $\mathrm{Hg}(\mathrm{OH})_{2}+2 \mathrm{CH}_{3} \mathrm{COO}^{-}+2 \mathrm{H}^{+}=\mathrm{Hg}\left(\mathrm{CH}_{3} \mathrm{COO}\right)_{2}+2 \mathrm{H}_{2} \mathrm{O}$ & 13.19 & Gårdfeldt et al. (2003) \\
\hline$\left[\mathrm{Hg}\left(\mathrm{CH}_{3} \mathrm{COO}\right)_{3}\right]^{-}$ & $\mathrm{Hg}(\mathrm{OH})_{2}+3 \mathrm{CH}_{3} \mathrm{COO}^{-}+2 \mathrm{H}^{+}=\left[\mathrm{Hg}\left(\mathrm{CH}_{3} \mathrm{COO}\right)_{3}\right]^{-}+2 \mathrm{H}_{2} \mathrm{O}$ & 19.49 & Gårdfeldt et al. (2003) \\
\hline$\left[\mathrm{Hg}\left(\mathrm{CH}_{3} \mathrm{COO}\right)_{3}\right]^{2}$ & $\mathrm{Hg}(\mathrm{OH})_{2}+4 \mathrm{CH}_{3} \mathrm{COO}^{-}+2 \mathrm{H}^{+}=\left[\mathrm{Hg}\left(\mathrm{CH}_{3} \mathrm{COO}\right)_{4}\right]^{2-}+2 \mathrm{H}_{2} \mathrm{O}$ & 23.29 & Gårdfeldt et al. (2003) \\
\hline $\mathrm{HgRS}^{+}$ & $\mathrm{Hg}(\mathrm{OH})_{2}+\mathrm{RS}^{-}+2 \mathrm{H}^{+}=\mathrm{HgRS}^{+}+2 \mathrm{H}_{2} \mathrm{O}$ & 34.69 & $\begin{array}{l}\text { Haitzer et al. (2002 } \\
\text { and 2003) } \\
\end{array}$ \\
\hline $\mathrm{HgCl}^{+}$ & $\mathrm{Hg}(\mathrm{OH})_{2}+\mathrm{Cl}^{-}+2 \mathrm{H}^{+}=\mathrm{HgCl}^{+}+2 \mathrm{H}_{2} \mathrm{O}$ & 12.85 & Powell et al. (2005) \\
\hline $\mathrm{HgCl}_{2}$ & $\mathrm{Hg}(\mathrm{OH})_{2}+2 \mathrm{Cl}^{-}+2 \mathrm{H}^{+}=\mathrm{HgCl}_{2}+2 \mathrm{H}_{2} \mathrm{O}$ & 19.22 & Powell et al. (2005) \\
\hline $\mathrm{HgCl}_{3}^{-}$ & $\mathrm{Hg}(\mathrm{OH})_{2}+3 \mathrm{Cl}^{-}+2 \mathrm{H}^{+}=\mathrm{HgCl}_{3}^{-}+2 \mathrm{H}_{2} \mathrm{O}$ & 20.12 & Powell et al. (2005) \\
\hline $\mathrm{HgCl}_{4}^{-2}$ & $\mathrm{Hg}(\mathrm{OH})_{2}+4 \mathrm{Cl}^{-}+2 \mathrm{H}^{+}=\mathrm{HgCl}_{4}^{-2}+2 \mathrm{H}_{2} \mathrm{O}$ & 20.53 & Powell et al. (2005) \\
\hline $\mathrm{HgClOH}$ & $\mathrm{Hg}(\mathrm{OH})_{2}+\mathrm{Cl}^{-}+\mathrm{H}^{+}=\mathrm{HgClOH}+\mathrm{H}_{2} \mathrm{O}$ & 9.31 & Powell et al. (2005) \\
\hline $\mathrm{HgF}^{+}$ & $\mathrm{Hg}(\mathrm{OH})_{2}+\mathrm{F}^{-}+2 \mathrm{H}^{+}=\mathrm{HgF}^{+}+2 \mathrm{H}_{2} \mathrm{O}$ & 8.08 & Martell et al. (2001) \\
\hline $\mathrm{HgI}^{+}$ & $\mathrm{Hg}(\mathrm{OH})_{2}+\mathrm{I}^{-}+2 \mathrm{H}^{+}=\mathrm{HgI}^{+}+2 \mathrm{H}_{2} \mathrm{O}$ & 18.89 & Martell et al. (2001) \\
\hline $\mathrm{HgI}_{2}$ & $\mathrm{Hg}(\mathrm{OH})_{2}+2 \mathrm{I}^{-}+2 \mathrm{H}^{+}=\mathrm{HgI}_{2}+2 \mathrm{H}_{2} \mathrm{O}$ & 30.10 & Martell et al. (2001) \\
\hline $\mathrm{HgI}_{3}{ }^{-}$ & $\mathrm{Hg}(\mathrm{OH})_{2}+3 \mathrm{I}^{-}+2 \mathrm{H}^{+}=\mathrm{HgI}_{3}^{-}+2 \mathrm{H}_{2} \mathrm{O}$ & 33.79 & Martell et al. (2001) \\
\hline
\end{tabular}


Table C 1 (Cont.)

\begin{tabular}{|c|c|c|c|}
\hline Hg species & Reactions & $\log K$ & Ref. \\
\hline $\mathrm{HgI}_{4}^{-2}$ & $\mathrm{Hg}(\mathrm{OH})_{2}+4 \mathrm{I}^{-}+2 \mathrm{H}^{+}=\mathrm{HgI}_{4}^{-2}+2 \mathrm{H}_{2} \mathrm{O}$ & 35.78 & Martell et al. (2001) \\
\hline $\mathrm{HgOH}^{+}$ & $\mathrm{Hg}(\mathrm{OH})_{2}+\mathrm{H}^{+}=\mathrm{HgOH}^{+}+\mathrm{H}_{2} \mathrm{O}$ & 2.70 & $\begin{array}{c}\text { Hurley et al. (1994) } \\
\text { and Benoit et al. } \\
(1999)\end{array}$ \\
\hline $\mathrm{Hg}(\mathrm{OH})_{3}^{-}$ & $\mathrm{Hg}(\mathrm{OH})_{2}+\mathrm{H}_{2} \mathrm{O}=\mathrm{Hg}(\mathrm{OH})_{3}^{-}+\mathrm{H}^{+}$ & 15.00 & $\begin{array}{c}\text { Hurley et al. (1994) } \\
\text { and Benoit et al. } \\
(1999)\end{array}$ \\
\hline $\mathrm{HgS}_{2}^{-2}$ & $\mathrm{Hg}(\mathrm{OH})_{2}+2 \mathrm{HS}^{-}=\mathrm{HgS}_{2}^{-2}+2 \mathrm{H}_{2} \mathrm{O}$ & 31.24 & $\begin{array}{c}\text { Hurley et al. (1994) } \\
\text { and Benoit et al. } \\
(1999)\end{array}$ \\
\hline $\mathrm{Hg}(\mathrm{HS})_{2}$ & $\mathrm{Hg}(\mathrm{OH})_{2}+2 \mathrm{HS}^{-}+2 \mathrm{H}^{+}=\mathrm{Hg}(\mathrm{HS})_{2}+2 \mathrm{H}_{2} \mathrm{O}$ & 43.82 & $\begin{array}{c}\text { Hurley et al. (1994) } \\
\text { and Benoit et al. } \\
(1999)\end{array}$ \\
\hline $\mathrm{HgSO}_{4}$ & $\mathrm{Hg}(\mathrm{OH})_{2}+\mathrm{SO}_{4}^{-2}+2 \mathrm{H}^{+}=\mathrm{HgSO}_{4}+2 \mathrm{H}_{2} \mathrm{O}$ & 7.49 & Hurley et al. (1994) \\
\hline
\end{tabular}

Table $\mathrm{C} 2 \mathrm{Hg}$ thermodynamic data at $25^{\circ} \mathrm{C}$; aq is aqueous, c is condensed, $\mathrm{g}$ is gas, liq is liquid, $\Delta \mathrm{H}_{\mathrm{f}}{ }^{\circ}$ is standard heat of formation, $\Delta \mathrm{G}_{\mathrm{f}}$ is standard gibbs free energy, $\mathrm{S}$ is entropy (Hepler and Olofsson 1974)

\begin{tabular}{|c|c|c|c|}
\hline Substance & $\Delta \mathrm{H}_{\mathrm{f}}^{\circ}, \mathrm{kJ} \mathrm{mol}^{-1}$ & $\Delta \mathrm{G}_{\mathrm{f}}^{\circ}, \mathrm{kJ} \mathrm{mol}^{-1}$ & $\mathrm{~S}^{\circ}, \mathrm{J} \mathrm{K}^{-1} \mathrm{~mol}^{-1}$ \\
\hline Hg (liq) & 0 & 0 & 76.02 \\
\hline $\mathrm{Hg}(\mathrm{g})$ & 61.317 & 31.853 & 174.85 \\
\hline $\operatorname{Hg}(\mathrm{aq})$ & 13.93 & 37.2 & -2.1 \\
\hline $\mathrm{Hg}^{+}(\mathrm{g})$ & 1074.53 & & \\
\hline $\mathrm{Hg}^{2+}(\mathrm{g})$ & 2890.4 & & \\
\hline $\mathrm{Hg}^{2+}(\mathrm{aq})$ & 170.16 & 164.703 & -36.23 \\
\hline $\mathrm{Hg}^{3+}(\mathrm{g})$ & 6192 & & \\
\hline $\mathrm{Hg}_{2}(\mathrm{~g})$ & 109 & 68.2 & 287.9 \\
\hline $\mathrm{Hg}_{2}^{2+}(\mathrm{aq})$ & 166.82 & 153.607 & 65.77 \\
\hline $\mathrm{HgO}$ (c, red, orthorh) & -90.83 & -58.555 & 70.29 \\
\hline $\mathrm{HgO}$ (c, yellow, orthorh) & -90.83 & -58.450 & 69.87 \\
\hline $\mathrm{HgO}$ (c, red, hexag) & -90.33 & -58.325 & 71.25 \\
\hline
\end{tabular}


Table C 2 (Cont.)

\begin{tabular}{|c|c|c|c|}
\hline Substance & $\Delta \mathbf{H}_{\mathrm{f}}^{\circ}, \mathrm{kJ} \mathrm{mol}^{-1}$ & $\Delta \mathrm{G}_{\mathrm{f}}^{\circ}, \mathrm{kJ} \mathrm{mol}^{-1}$ & $\mathrm{~S}^{\circ}, \mathrm{J} \mathrm{K}^{-1} \mathrm{~mol}^{-1}$ \\
\hline $\mathrm{HgO}(\mathrm{g})$ & & & 241.8 \\
\hline $\mathrm{HgH}(\mathrm{g})$ & 238 & 213 & 219.7 \\
\hline $\mathrm{Hg}(\mathrm{OH})^{+}(\mathrm{aq})$ & -84.5 & -52.01 & 69.0 \\
\hline $\mathrm{Hg}(\mathrm{OH})_{2}(\mathrm{aq})$ & -359.8 & -274.5 & 126.4 \\
\hline $\mathrm{Hg}(\mathrm{OH})_{3}^{-}(\mathrm{aq})$ & & -427.2 & \\
\hline $\mathrm{HHgO}_{2}^{-}(\mathrm{aq})$ & & -190.0 & \\
\hline $\operatorname{HgF}(g)$ & 2.9 & -18.4 & 248.28 \\
\hline $\operatorname{HgF}^{+}(\mathrm{aq})$ & -159.0 & -123.0 & -8 \\
\hline $\mathrm{Hg}_{2} \mathrm{~F}_{2}(\mathrm{c})$ & -485 & -431 & 167 \\
\hline $\mathrm{HgCl}(\mathrm{g})$ & 83.7 & 62.8 & 259.9 \\
\hline $\mathrm{HgCl}^{+}(\mathrm{aq})$ & -19.7 & -5.0 & 71 \\
\hline $\mathrm{HgCl}_{2}(\mathrm{c})$ & -225.9 & -180.3 & 146.0 \\
\hline $\mathrm{HgCl}_{2}(\mathrm{~g})$ & -143.1 & -141.8 & 294.68 \\
\hline $\mathrm{HgCl}_{2}(\mathrm{aq})$ & -217.1 & -172.8 & 151 \\
\hline $\mathrm{HgCl}_{3}^{-}(\mathrm{aq})$ & -389.5 & -308.8 & 205 \\
\hline $\mathrm{HgCl}_{4}{ }^{2-}(\mathrm{aq})$ & -554.8 & -446.4 & 289 \\
\hline $\mathrm{HgCl}(\mathrm{OH})(\mathrm{aq})$ & -288.7 & -222.2 & 134 \\
\hline $\mathrm{Hg}_{2} \mathrm{Cl}_{2}$ (c) & -265.579 & -210.773 & 191.42 \\
\hline $\operatorname{HgBr}(\mathrm{g})$ & 105 & 67 & 271.5 \\
\hline $\mathrm{HgBr}^{+}(\mathrm{aq})$ & 5.4 & 9.2 & 75 \\
\hline $\mathrm{HgBr}_{2}(\mathrm{c})$ & -170.7 & -153.1 & 172 \\
\hline $\mathrm{HgBr}_{2}(\mathrm{~g})$ & -86.6 & -113.8 & 320.12 \\
\hline $\mathrm{HgBr}_{2}(\mathrm{aq})$ & -161.5 & -142.7 & 167 \\
\hline $\mathrm{HgBr}_{3}^{-}(\mathrm{aq})$ & -294.1 & -259.0 & 255 \\
\hline
\end{tabular}


Table C 2 (Cont.)

\begin{tabular}{|c|c|c|c|}
\hline Substance & $\Delta \mathrm{H}_{\mathrm{f}}^{\circ}, \mathrm{kJ} \mathrm{mol}^{-1}$ & $\Delta \mathrm{G}_{\mathrm{f}}^{\circ}, \mathbf{k J} \mathrm{mol}^{-1}$ & $\mathbf{S}^{\circ}, \mathrm{J} \mathrm{K}^{-1} \mathrm{~mol}^{-1}$ \\
\hline $\mathrm{HgBr}_{4}{ }^{2-}(\mathrm{aq})$ & -431.8 & -370.7 & 305 \\
\hline $\mathrm{HgBr}(\mathrm{OH})(\mathrm{aq})$ & & -207.9 & \\
\hline $\operatorname{HgBrCl}(\mathrm{g})$ & & & 299.4 \\
\hline $\operatorname{HgBrCl}(\mathrm{aq})$ & & -161.5 & \\
\hline $\mathrm{Hg}_{2} \mathrm{Br}_{2}(\mathrm{c})$ & -206.94 & -181.084 & 217.6 \\
\hline $\operatorname{HgI}(\mathrm{g})$ & 132.2 & 91.6 & 281.42 \\
\hline $\operatorname{HgI}^{+}(\mathrm{aq})$ & 42.3 & 40.2 & 75 \\
\hline $\mathrm{HgI}_{2}(\mathrm{c}, \mathrm{red})$ & -105.4 & -101.7 & 180 \\
\hline $\mathrm{HgI}_{2}(\mathrm{c}$, yellow $)$ & -102.9 & & \\
\hline $\mathrm{HgI}_{2}(\mathrm{~g})$ & -17.2 & -59.8 & 336.02 \\
\hline $\mathrm{HgI}_{2}(\mathrm{aq})$ & -80.3 & -74.9 & 172 \\
\hline $\mathrm{HgI}_{3}-(\mathrm{aq})$ & -153.6 & -148.1 & 297 \\
\hline $\mathrm{HgI}_{4}^{2-}(\mathrm{aq})$ & -236.0 & -211.3 & 356 \\
\hline $\mathrm{HgI}(\mathrm{OH})(\mathrm{aq})$ & & -173.2 & \\
\hline $\mathrm{HgICl}(\mathrm{aq})$ & & -128.4 & \\
\hline $\operatorname{HgIBr}(\mathrm{g})$ & & & 320.45 \\
\hline $\operatorname{HgIBr}(\mathrm{aq})$ & & -111.3 & \\
\hline $\mathrm{HgIBr}_{3}{ }^{2-}(\mathrm{aq})$ & & -336.69 & \\
\hline $\mathrm{HgI} 2 \mathrm{Br}_{2}{ }^{2-}(\mathrm{aq})$ & & -297.40 & \\
\hline $\mathrm{HgI} 2 \mathrm{Br}^{2-}(\mathrm{aq})$ & & -255.6 & \\
\hline $\mathrm{Hg}_{2} \mathrm{I}_{2}(\mathrm{c})$ & -121.34 & -111.002 & 233.5 \\
\hline $\operatorname{HgS}(\mathrm{c}, \mathrm{red})$ & -54.0 & -46.4 & 82.4 \\
\hline HgS(c, black) & -50.2 & -44.4 & 88.7 \\
\hline $\mathrm{HgSO}_{4}(\mathrm{c})$ & -707.5 & -594 & 142 \\
\hline
\end{tabular}


Table C 2 (Cont.)

\begin{tabular}{|c|c|c|c|}
\hline Substance & $\Delta \mathbf{H}_{\mathrm{f}}^{\circ}, \mathbf{k J ~ m o l}{ }^{-1}$ & $\Delta \mathrm{G}_{\mathrm{f}}^{\circ}, \mathbf{k J ~ m o l}{ }^{-1}$ & $\mathrm{~S}^{\circ}, \mathrm{J} \mathrm{K}^{-1} \mathrm{~mol}^{-1}$ \\
\hline $\mathrm{Hg}_{2} \mathrm{SeO}_{3}(\mathrm{c})$ & & -297.5 & \\
\hline $\operatorname{HgTe}(\mathrm{c})$ & -33.9 & -28.0 & 106.7 \\
\hline $\mathrm{Hg}\left(\mathrm{N}_{3}\right)^{+}(\mathrm{aq})$ & & 468.6 & \\
\hline $\mathrm{Hg}\left(\mathrm{N}_{3}\right)_{2}(\mathrm{aq})$ & & 774.0 & \\
\hline $\mathrm{Hg}\left(\mathrm{N}_{3}\right)_{2}(\mathrm{c})$ & 592.0 & 746.4 & 208.8 \\
\hline $\mathrm{Hg}\left(\mathrm{NO}_{3}\right)^{+}(\mathrm{aq})$ & & 51.5 & \\
\hline $\mathrm{Hg}\left(\mathrm{NO}_{3}\right)_{2}(\mathrm{aq})$ & & -50.2 & \\
\hline $\mathrm{Hg}\left(\mathrm{NO}_{2}\right)_{4}{ }^{2-}(\mathrm{aq})$ & & -46.9 & \\
\hline $\mathrm{Hg}\left(\mathrm{NH}_{3}\right)_{2}^{+}(\mathrm{aq})$ & & 87.9 & \\
\hline $\mathrm{Hg}\left(\mathrm{NH}_{3}\right)_{2}{ }^{2+}(\mathrm{aq})$ & -94.6 & 11.7 & 172 \\
\hline $\mathrm{Hg}\left(\mathrm{NH}_{3}\right)_{3}{ }^{2+}(\mathrm{aq})$ & -188.3 & -20.5 & 259 \\
\hline $\mathrm{Hg}\left(\mathrm{NH}_{3}\right)_{4}{ }^{2+}(\mathrm{aq})$ & -283.7 & -51.5 & 335 \\
\hline $\mathrm{HgNH}_{2} \mathrm{Br}$ (c, orthorh) & & & 133.18 \\
\hline $\mathrm{HgNH}_{2} \mathrm{Br}$ (c, cubic) & & & 130.08 \\
\hline $\mathrm{Hg}_{2}\left(\mathrm{P}_{2} \mathrm{O}_{7}\right)^{2-}(\mathrm{aq})$ & & -1820 & \\
\hline $\mathrm{Hg}_{2}(\mathrm{OH})\left(\mathrm{P}_{2} \mathrm{O}_{7}\right)^{3-}(\mathrm{aq})$ & & -2012 & \\
\hline $\mathrm{Hg}_{2}\left(\mathrm{P}_{2} \mathrm{O}_{7}\right)_{2}{ }^{6-}(\mathrm{aq})$ & & -3694 & \\
\hline $\mathrm{Hg}_{2}(\mathrm{OH})_{2}\left(\mathrm{P}_{2} \mathrm{O}_{7}\right)^{4-}(\mathrm{aq})$ & & -2197 & \\
\hline $\mathrm{Hg}\left(\mathrm{C}_{2} \mathrm{O}_{4}\right)(\mathrm{c})$ & -678.2 & & \\
\hline $\mathrm{Hg}_{2}\left(\mathrm{CO}_{3}\right)(\mathrm{c})$ & -553.5 & -468.2 & 180 \\
\hline $\mathrm{Hg}_{2}\left(\mathrm{C}_{2} \mathrm{O}_{4}\right)(\mathrm{c})$ & & -593.3 & \\
\hline $\mathrm{Hg}_{2}\left(\mathrm{C}_{2} \mathrm{O}_{4}\right)_{2}{ }^{2-}(\mathrm{aq})$ & & -1234.3 & \\
\hline $\mathrm{Hg}_{2}(\mathrm{OH})\left(\mathrm{C}_{2} \mathrm{O}_{4}\right)^{-}(\mathrm{aq})$ & & -752.3 & \\
\hline
\end{tabular}


Table $\mathrm{C} 3 \mathrm{Hg}$-Organic thermodynamicdata; aq is aqueous, $\mathrm{c}$ is condensed, $\mathrm{g}$ is gas, liq is liquid, $\Delta \mathrm{H}_{\mathrm{f}}{ }^{\circ}$ is standard heat of formation, $\Delta \mathrm{G}_{\mathrm{f}}$ is standard gibbs free energy, $\mathrm{S}$ is entropy

(Hepler and Olofsson 1974)

\begin{tabular}{|c|c|c|c|}
\hline Substance & $\Delta \mathbf{H}_{\mathrm{f}}^{\circ}, \mathrm{kJ} \mathrm{mol}^{-1}$ & $\Delta G_{f}^{\circ}, \mathbf{k J ~ m o l}^{-1}$ & $\mathrm{~S}^{\circ}, \mathrm{J} \mathrm{K}^{-1} \mathrm{~mol}^{-1}$ \\
\hline $\mathrm{Hg}\left(\mathrm{CH}_{3}\right)(\mathrm{g})$ & 167 & & \\
\hline $\mathrm{Hg}\left(\mathrm{CH}_{3}\right)_{2}$ (liq) & 59.8 & 140.2 & 209 \\
\hline $\mathrm{Hg}\left(\mathrm{CH}_{3}\right)_{2}(\mathrm{~g})$ & 94.39 & 146.0 & 305 \\
\hline $\mathrm{Hg}\left(\mathrm{CH}_{3}\right)\left(\mathrm{C}_{2} \mathrm{H}_{5}\right)$ (liq) & 46.4 & & \\
\hline $\mathrm{Hg}\left(\mathrm{C}_{2} \mathrm{H}_{5}\right)_{2}$ (liq) & 30.1 & & \\
\hline $\mathrm{Hg}\left(\mathrm{C}_{2} \mathrm{H}_{5}\right)_{2}(\mathrm{~g})$ & 75.3 & & \\
\hline Hg biphenyl (c) & 282.8 & & \\
\hline $\begin{array}{c}\mathrm{Hg}_{2} \mathrm{Ac}_{2}(\mathrm{c})(\mathrm{Ac}-= \\
\text { acetate })\end{array}$ & -841 & -640.11 & 310 \\
\hline $\mathrm{Hg}\left(\mathrm{CH}_{3}\right) \mathrm{Cl}(\mathrm{c})$ & -116.3 & & \\
\hline $\mathrm{Hg}\left(\mathrm{CH}_{3}\right) \mathrm{Cl}(\mathrm{g})$ & -52.3 & & \\
\hline $\mathrm{Hg}\left(\mathrm{C}_{2} \mathrm{H}_{5}\right) \mathrm{Cl}(\mathrm{c})$ & -139.3 & & \\
\hline $\mathrm{Hg}\left(\mathrm{C}_{2} \mathrm{H}_{5}\right) \mathrm{Cl}(\mathrm{g})$ & -62.8 & & \\
\hline $\mathrm{HgCl}_{2} \mathrm{CH}_{3} \mathrm{OH}$ (c) & -474.9 & -347.7 & 243 \\
\hline $\mathrm{HgCl}_{2} 2 \mathrm{CH}_{3} \mathrm{OH}(\mathrm{c})$ & -720 & -514.6 & 335 \\
\hline $\mathrm{Hg}\left(\mathrm{CH}_{3}\right) \mathrm{Br}(\mathrm{c})$ & -85.8 & & \\
\hline $\mathrm{Hg}\left(\mathrm{CH}_{3}\right) \mathrm{Br}(\mathrm{g})$ & -18.4 & & \\
\hline $\mathrm{Hg}\left(\mathrm{C}_{2} \mathrm{H}_{5}\right) \mathrm{Br}(\mathrm{c})$ & -106.7 & & \\
\hline $\mathrm{Hg}\left(\mathrm{C}_{2} \mathrm{H}_{5}\right) \mathrm{Br}(\mathrm{g})$ & -30.1 & & \\
\hline $\mathrm{Hg}\left(\mathrm{CH}_{3}\right) \mathrm{I}(\mathrm{c})$ & -42.7 & & \\
\hline $\mathrm{Hg}\left(\mathrm{CH}_{3}\right) \mathrm{I}(\mathrm{g})$ & 21.8 & & \\
\hline $\mathrm{Hg}\left(\mathrm{C}_{2} \mathrm{H}_{5}\right) \mathrm{I}(\mathrm{c})$ & -65.7 & & \\
\hline
\end{tabular}


Table C 3 (Cont.)

\begin{tabular}{|c|c|c|c|}
\hline Substance & $\Delta \mathrm{H}_{\mathrm{f}}^{\circ}, \mathrm{kJ} \mathrm{mol}^{-1}$ & $\Delta \mathrm{G}_{\mathrm{f}}^{\circ}, \mathrm{kJ} \mathrm{mol}{ }^{-1}$ & $\mathrm{~S}^{\circ}, \mathrm{J} \mathrm{K}^{-1} \mathrm{~mol}^{-1}$ \\
\hline $\mathrm{Hg}(\mathrm{CN})^{+}(\mathrm{aq})$ & 224.7 & 238.5 & 66.1 \\
\hline $\mathrm{Hg}(\mathrm{CN}) \mathrm{Cl}(\mathrm{aq})$ & & 67.4 & \\
\hline $\mathrm{Hg}(\mathrm{CN}) \mathrm{Br}(\mathrm{aq})$ & & 84.1 & \\
\hline $\mathrm{Hg}(\mathrm{CN}) \mathrm{I}(\mathrm{aq})$ & & 121.3 & \\
\hline $\mathrm{Hg}\left(\mathrm{CN}_{2}\right)(\mathrm{c})$ & 276 & & \\
\hline $\mathrm{Hg}(\mathrm{CN})_{2}(\mathrm{c})$ & 263.6 & & \\
\hline $\mathrm{Hg}(\mathrm{CN})_{2}(\mathrm{~g})$ & 381 & & \\
\hline $\mathrm{Hg}(\mathrm{CN})_{2}(\mathrm{aq})$ & 277.4 & 312.5 & 161.1 \\
\hline $\mathrm{Hg}(\mathrm{CN})_{2} \mathrm{Cl}^{-}(\mathrm{aq})$ & & 182.8 & \\
\hline $\mathrm{Hg}(\mathrm{CN})_{3}^{-}(\mathrm{aq})$ & 396.2 & 463.6 & 219.7 \\
\hline $\mathrm{Hg}(\mathrm{CN})_{3} \mathrm{Cl}_{2}^{-}(\mathrm{aq})$ & & 335 & \\
\hline $\mathrm{Hg}(\mathrm{CN})_{3} \mathrm{Br}_{2}^{-}(\mathrm{aq})$ & & 356 & \\
\hline $\begin{array}{c}\mathrm{Hg}(\mathrm{CN})_{2}(\mathrm{tu})(\mathrm{aq})(\mathrm{tu}= \\
\text { thiourea })\end{array}$ & 206.3 & & \\
\hline $\mathrm{Hg}(\mathrm{CN})_{2}(\mathrm{tu})_{2}(\mathrm{aq})$ & 105.0 & & \\
\hline $\begin{array}{c}\mathrm{Hg}(\mathrm{ONC})_{2}(\mathrm{c})(\text { mercuric } \\
\text { fulminate) }\end{array}$ & 268 & & \\
\hline $\mathrm{Hg}(\mathrm{SCN})^{+}(\mathrm{aq})$ & & 206.3 & \\
\hline $\mathrm{Hg}(\mathrm{SCN}) \mathrm{Cl}(\mathrm{aq})$ & & 35.6 & \\
\hline $\mathrm{Hg}(\mathrm{SCN}) \mathrm{Br}(\mathrm{aq})$ & & 51.5 & \\
\hline $\mathrm{Hg}(\mathrm{SCN})_{2}(\mathrm{aq})$ & 195.4 & & \\
\hline $\mathrm{Hg}(\mathrm{SCN})_{3}^{-}(\mathrm{aq})$ & & 329.7 & \\
\hline $\mathrm{Hg}(\mathrm{SCN})_{4}{ }^{2-}(\mathrm{aq})$ & 325.5 & 411.7 & 452 \\
\hline $\mathrm{Hg}(\mathrm{OH})(\mathrm{SCN})(\mathrm{aq})$ & & 461.9 & \\
\hline $\mathrm{Hg}(\mathrm{SCN})(\mathrm{CN})_{3}{ }^{2-}(\mathrm{aq})$ & & 553.5 & \\
\hline
\end{tabular}


Table C 3 (Cont.)

\begin{tabular}{|c|c|c|c|}
\hline Substance & $\Delta \mathrm{H}_{\mathrm{f}}^{\circ}, \mathbf{k J ~ m o l}{ }^{-1}$ & $\Delta \mathrm{G}_{\mathrm{f}}^{\circ}, \mathrm{kJ} \mathrm{mol}{ }^{-1}$ & $\mathrm{~S}^{\circ}, \mathrm{J} \mathrm{K}^{-1} \mathrm{~mol}^{-1}$ \\
\hline $\mathrm{Hg}_{2}(\mathrm{SCN})_{2}(\mathrm{c})$ & & 226.4 & \\
\hline $\begin{array}{c}\mathrm{Hg}(\mathrm{ma})_{2}{ }^{+}(\mathrm{aq})(\mathrm{ma}= \\
\text { methylamine })\end{array}$ & & 136.0 & \\
\hline $\operatorname{Hg}(\mathrm{ma})_{2}^{+}(\mathrm{aq})$ & -55.6 & 104.2 & 265.3 \\
\hline $\operatorname{HgCl}(\mathrm{ma})_{2}^{+}(\mathrm{aq})$ & -148.5 & -34.7 & 168.6 \\
\hline $\mathrm{Hg}(\mathrm{gl})^{+}(\mathrm{aq})(\mathrm{gl}-=$ glycinate $)$ & & -208.8 & \\
\hline $\mathrm{Hg}(\mathrm{gl})_{2}(\mathrm{aq})$ & -860.2 & -574.9 & 264 \\
\hline $\mathrm{HgCl}(\mathrm{gl})(\mathrm{aq})$ & -545.2 & -376.1 & 192 \\
\hline $\mathrm{HgCl}(\mathrm{en})^{+}(\mathrm{aq})$ & -141.8 & & \\
\hline $\mathrm{Hg}_{2} \mathrm{CrO}_{4}(\mathrm{c})$ & & -623.8 & \\
\hline
\end{tabular}

Table C 4 Ion exchange coefficients for various ions related to $\mathrm{Hg}$ (II) (Khan and Alam, 2004)

\begin{tabular}{|lc|}
\hline Ions & Ion exchange coefficients \\
& $\mathbf{K}_{\mathbf{H g} / \mathbf{M}}$ \\
\hline $\mathrm{Na}^{+}$ & 0.04 \\
\hline $\mathrm{K}^{+}$ & 0.03 \\
\hline $\mathrm{Mg}^{2+}$ & 0.02 \\
\hline $\mathrm{Co}^{2+}$ & 0.04 \\
\hline $\mathrm{Ni}^{2+}$ & 0.02 \\
\hline $\mathrm{Cu}^{2+}$ & 0.03 \\
\hline $\mathrm{Mn}^{2+}$ & 0.03 \\
\hline $\mathrm{Zn}^{2+}$ & 0.02 \\
\hline $\mathrm{Pb}^{2+}$ & 0.07 \\
\hline $\mathrm{Al}^{3+}$ & 0.01 \\
\hline $\mathrm{Fe}^{3+}$ & 0.05 \\
\hline
\end{tabular}


Table C 5 The surface complexation and the intrinsic equilibrium constants (log Kint) of $\mathrm{Hg}$ (II) adsorption on ferrihydrite $(\equiv \mathrm{Hfo})$, quartz ( $\equiv$ Sio), and gibbsite (三Aloh) (Dzombak and Morel, 1990; Sarkar et al., 1999)

\begin{tabular}{|c|c|}
\hline Sorption Reactions & $\log K_{\text {int }}$ \\
\hline$\equiv \mathrm{Hfo} \_\mathrm{sOH}+\mathrm{Hg}(\mathrm{OH})_{2}+\mathrm{H}^{+}=\equiv \mathrm{Hfo} \_s \mathrm{OHg}{ }^{+}+2 \mathrm{H}_{2} \mathrm{O}$ & 13.95 \\
\hline$\equiv \mathrm{Hfo} \_$wOH $+\mathrm{Hg}(\mathrm{OH})_{2}+\mathrm{H}^{+}=\equiv \mathrm{Hfo} \_{ } \mathrm{OHg}^{+}+2 \mathrm{H}_{2} \mathrm{O}$ & 12.64 \\
\hline$\equiv$ Sio_OH $+\mathrm{Na}+=\equiv$ Sio_Na ${ }^{+}+\mathrm{H}^{+}$ & -6.21 \\
\hline$\equiv \mathrm{Sio} \_\mathrm{OH}+\mathrm{Hg}^{2+}+\mathrm{H}_{2} \mathrm{O}=\equiv$ Sio_OHgOH $+2 \mathrm{H}^{+}$ & -2.19 \\
\hline$\equiv$ Sio_OH $+\mathrm{Hg}^{2+}+2 \mathrm{H}_{2} \mathrm{O}=\equiv$ Sio_OHg $(\mathrm{OH})_{2}{ }^{-}+3 \mathrm{H}+$ & -7.75 \\
\hline$\equiv$ Sio_OH $+\mathrm{Hg}^{2+}+\mathrm{Cl}^{-}+\mathrm{H}_{2} \mathrm{O}=\equiv$ Sio_OHgOHCl${ }^{-}+2 \mathrm{H}^{+}$ & 2.14 \\
\hline$\equiv$ Sio_OH $+\mathrm{Hg}^{2+}+\mathrm{PO}_{4}{ }^{3-}+\mathrm{H}_{2} \mathrm{O}=\equiv$ Sio_OPO${ }_{3} \mathrm{Hg}(\mathrm{OH})_{2}{ }^{2-}+\mathrm{H}^{+}$ & 11.61 \\
\hline$\equiv$ Aloh_OH $+\mathrm{H}^{+}=\equiv$ Aloh_OH ${ }_{2}^{+}$ & 2.77 \\
\hline$\equiv$ Aloh_OH $=\equiv$ Aloh_O $\mathrm{O}^{-}+\mathrm{H}^{+}$ & -6.77 \\
\hline$\equiv$ Aloh_OH $+\mathrm{Na}^{+}=\equiv$ Aloh_ $\mathrm{Na}^{+}+\mathrm{H}^{+}$ & -6.21 \\
\hline$\equiv$ Aloh_OH $+\mathrm{Hg}^{2+}+\mathrm{H} 2 \mathrm{O}=\equiv$ Aloh_OHgOH $+2 \mathrm{H}^{+}$ & -2.19 \\
\hline$\equiv$ Aloh_OH $+\mathrm{Hg}^{2+}+2 \mathrm{H}_{2} \mathrm{O}=\equiv$ Aloh_OHg $(\mathrm{OH})_{2}^{-}+3 \mathrm{H}^{+}$ & -7.75 \\
\hline$\equiv$ Aloh_OH $+\mathrm{Hg}_{2+}+\mathrm{Cl}^{-}+\mathrm{H}_{2} \mathrm{O}=\equiv$ Aloh_OHgOHCl${ }^{-}+2 \mathrm{H}^{+}$ & 2.14 \\
\hline$\equiv$ Aloh_OH $+\mathrm{Hg}^{2+}+\mathrm{PO}_{4}{ }^{3-}+\mathrm{H}_{2} \mathrm{O}=\equiv$ Aloh_OPO${ }_{3} \mathrm{Hg}(\mathrm{OH})_{2}{ }^{2-}+\mathrm{H}^{+}$ & 11.61 \\
\hline
\end{tabular}




\section{APPENDIX D}

The location of selected Coastal Florida aquifer monitoring stations are shown in

Figure D 1. The data collected from over 30 stations throughout the South Florida

District during years 2005 and 2006 are shown in Table D 1 and D 2 respectively.

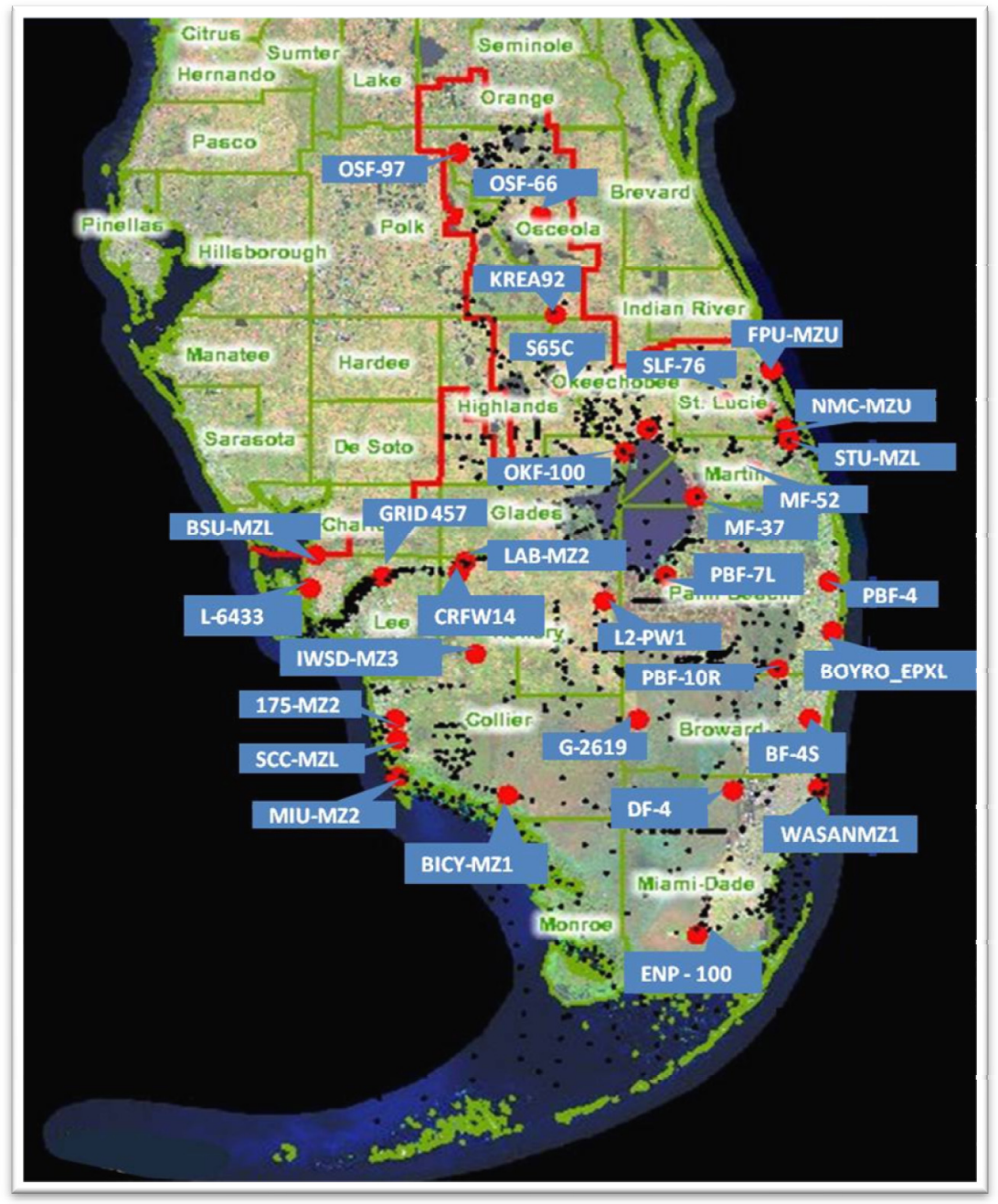

Figure D 1 the locations of over 30 water monitoring stations in 16-county region covered by the South Florida District (modified after DBHYDRO) 
Table D 1 Florida aquifer quality data collected during year 2005. Salinity in ppt (\%o), major ion concentrations in mg/L (DBHYDRO)

\begin{tabular}{|c|c|c|c|c|c|c|c|c|c|c|c|c|c|}
\hline $\begin{array}{l}\text { Project } \\
\text { Code }\end{array}$ & Station ID & $\begin{array}{l}\text { Collected } \\
\text { date }\end{array}$ & $\mathbf{T}\left(\mathbf{C}^{\circ}\right)$ & pH & Salinity & $\mathbf{N a}^{+}$ & $\mathrm{Mg}^{2+}$ & $\mathbf{K}^{+}$ & $\mathrm{Ca}^{2+}$ & $\mathrm{Cl}^{-}$ & $\mathrm{SO}_{4}{ }^{2-}$ & Alka & DO \\
\hline RFGW & BICY-MZ1 & $1-F e b-05$ & 27.47 & 8.72 & 3.38 & 1040 & 135 & 44.5 & 68.8 & 1700 & 450 & 85.7 & 0.24 \\
\hline RFGW & BICY-MZ1 & 11-Apr-05 & 27.82 & 9.02 & 3.34 & 1050 & 123 & 42.1 & 42.6 & 1900 & 420 & 99 & 0.1 \\
\hline RFGW & BICY-MZ1 & 12-Jul-05 & 27.77 & 9.21 & 3.38 & 1040 & 116 & 41.9 & 39 & 1800 & 410 & 37 & 0.12 \\
\hline RFGW & BICY-MZ1 & 19-Sep-05 & 27.85 & 8.48 & 2.06 & 1040 & 128 & 42.7 & 43.4 & 1700 & 450 & 55 & 2.06 \\
\hline RFGW & BICY-MZ1 & 29-Dec-05 & 27.85 & 8.83 & 3.32 & 1030 & 130 & 42 & 50.7 & 1800 & 450 & 73 & 0.16 \\
\hline RFGW & BICY-MZ2 & $1-F e b-05$ & 27.74 & 7.65 & 5.21 & 1500 & 188 & 60.4 & 152 & 2900 & 600 & 148 & 0.32 \\
\hline RFGW & BICY-MZ2 & 11-Apr-05 & 28.12 & 7.69 & 5.27 & 1550 & 180 & 57.8 & 145 & 2900 & 610 & 150 & 0.11 \\
\hline RFGW & BICY-MZ2 & 11-Jul-05 & 28.34 & 7.47 & 5.37 & 1680 & 192 & 62.3 & 153 & & 570 & 150 & 0.04 \\
\hline RFGW & BICY-MZ2 & 19-Sep-05 & 28.29 & 7.45 & 1.07 & 1570 & 184 & 59.6 & 147 & 3000 & 590 & 150 & 1.07 \\
\hline RFGW & BICY-MZ2 & 29-Dec-05 & 28.19 & 7.66 & 5.22 & 1560 & 192 & 58.3 & 160 & 2600 & 1200 & 160 & 0.17 \\
\hline RFGW & BICY-MZ3 & 31-Jan-05 & 27.8 & 8.5 & 27.29 & 8010 & 817 & 238 & 488 & 15000 & 1400 & 29.9 & 0.47 \\
\hline RFGW & BICY-MZ3 & 12-Apr-05 & 27.71 & 7.57 & 27.44 & 8160 & 860 & 246 & 567 & 17000 & 1200 & 130 & 0.12 \\
\hline RFGW & BICY-MZ3 & 12-Jul-05 & 28.35 & 7.39 & 27.99 & 8320 & 839 & 244 & 565 & 15000 & 1500 & 120 & 0.2 \\
\hline RFGW & BICY-MZ3 & 4-Oct-05 & 27.78 & 7.45 & 26.52 & 8730 & 907 & 272 & 600 & 15000 & 1300 & 140 & 0.37 \\
\hline RFGW & BICY-MZ3 & 29-Dec-05 & 28.45 & 7.48 & 27.23 & 8400 & 897 & 245 & 605 & 16000 & 2700 & 130 & 0.13 \\
\hline RFGW & BICY-MZ4 & 1-Feb-05 & 27.84 & 6.71 & 34.33 & 11600 & 1080 & 375 & 779 & 21000 & 2800 & 190 & 0.63 \\
\hline RFGW & BICY-MZ4 & 12-Apr-05 & 27.61 & 7.05 & 34.8 & 10600 & 1090 & 377 & 773 & 20000 & 4500 & 150 & 0 \\
\hline RFGW & BICY-MZ4 & 12-Jul-05 & 28.46 & 6.92 & 35.08 & 11300 & 1100 & 382 & 804 & 19000 & 2600 & 150 & 1.85 \\
\hline RFGW & BICY-MZ4 & 4-Oct-05 & 29.21 & 6.85 & 33.65 & 11000 & 1070 & 380 & 743 & 20000 & 2500 & 190 & 1.16 \\
\hline
\end{tabular}


Table D 1 (Cont.)

\begin{tabular}{|c|c|c|c|c|c|c|c|c|c|c|c|c|c|}
\hline $\begin{array}{l}\text { Project } \\
\text { Code }\end{array}$ & Station ID & $\begin{array}{c}\text { Collected } \\
\text { date }\end{array}$ & $\mathbf{T}\left(\mathbf{C}^{\circ}\right)$ & pH & Salinity & $\mathbf{N a}^{+}$ & $\mathrm{Mg}^{2+}$ & $\mathbf{K}^{+}$ & $\mathrm{Ca}^{2+}$ & $\mathrm{Cl}^{-}$ & $\mathrm{SO}_{4}{ }^{2-}$ & Alka & DO \\
\hline RFGW & BSU-MZL & 14-Apr-05 & 31.83 & 7.58 & 33.3 & 10300 & 1120 & 351 & 678 & 20000 & 4600 & 110 & 2.94 \\
\hline RFGW & BSU-MZL & 14-Jul-05 & 32.10 & 7.49 & 33.65 & 10300 & 1080 & 362 & 654 & 19000 & 2400 & 120 & 3.16 \\
\hline RFGW & BSU-MZL & 22-Sep-05 & 33.09 & 7.62 & 31.95 & 10400 & 1070 & 352 & 650 & 19000 & 2800 & 120 & 2.08 \\
\hline RFGW & BSU-MZL & 28-Dec-05 & 31.96 & 7.54 & 33.92 & 9670 & 1060 & 345 & 659 & 19000 & 250 & 120 & 3.62 \\
\hline RFGW & BSU-MZU & 3-Feb-05 & 31.91 & 7.84 & 1.49 & 337 & 79.1 & 16 & 102 & 690 & & 136 & 0.4 \\
\hline RFGW & BSU-MZU & 14-Apr-05 & 31.96 & 7.7 & 1.49 & 329 & 78.2 & 15.6 & 99.8 & 700 & 250 & 130 & 0.73 \\
\hline RFGW & BSU-MZU & 14-Jul-05 & 33.81 & 7.62 & 1.51 & 329 & 77.2 & 15.3 & 97.6 & 700 & 300 & 140 & 0.18 \\
\hline RFGW & BSU-MZU & 22-Sep-05 & 31.87 & 7.69 & 1.46 & 329 & 77.1 & 15.4 & 97 & 780 & 240 & 150 & 0.45 \\
\hline RFGW & DF-4 & 25-Jan-05 & 22.94 & 7.94 & 3.41 & 962 & 133 & 33.3 & 108 & 1700 & 530 & 120 & 0.62 \\
\hline RFGW & DF-4 & 27-Apr-05 & 22.67 & 7.95 & 3.59 & 1010 & 142 & 36.7 & 128 & 1900 & 520 & 140 & 0.03 \\
\hline RFGW & DF-4 & 20-Jun-05 & 21.83 & 7.64 & 3.44 & 985 & 133 & 33.6 & 107 & 1800 & 550 & 120 & 0.06 \\
\hline RFGW & DF-4 & 27-Sep-05 & 21.81 & 7.6 & 3.31 & 965 & 133 & 33.8 & 104 & 1760 & 424 & 120 & 0.08 \\
\hline RFGW & DF-5 & 25-Jan-05 & 23.03 & 9.78 & 2.98 & 917 & 21.8 & 42.7 & 153 & 1500 & 360 & 130 & 0.21 \\
\hline RFGW & DF-5 & 5-Apr-05 & 24.11 & 9.7 & 2.98 & 892 & 34.8 & 42.2 & 155 & 1700 & 410 & 5 & 0.91 \\
\hline RFGW & DF-5 & 20-Jun-05 & 22.77 & 9.62 & 3.02 & 891 & 35.7 & 40.7 & 146 & 1600 & 470 & 6.4 & 0.08 \\
\hline RFGW & DF-5 & 27-Sep-05 & 22.9 & 9.49 & 2.93 & 920 & 39.3 & 42.8 & 166 & 1600 & 410 & 9 & 0.1 \\
\hline RFGW & ENP-100 & 25-Jan-05 & 28.14 & 7.26 & 5.22 & 1480 & 170 & 53.8 & 150 & 2800 & 480 & 150 & 0.23 \\
\hline RFGW & ENP-100 & 5-Apr-05 & 28.38 & 7.47 & 5.16 & 1520 & 171 & 54.7 & 149 & 2800 & 490 & 160 & 0.33 \\
\hline RFGW & ENP-100 & 8-Jul-05 & 28.07 & 7.29 & 5.09 & 1470 & 169 & 53.5 & 145 & 2800 & 490 & 150 & 0.87 \\
\hline
\end{tabular}


Table D 1 (Cont.)

\begin{tabular}{|c|c|c|c|c|c|c|c|c|c|c|c|c|c|}
\hline $\begin{array}{c}\text { Project } \\
\text { Code }\end{array}$ & Station ID & $\begin{array}{c}\text { Collected } \\
\text { date }\end{array}$ & $\mathbf{T}\left(\mathbf{C}^{\circ}\right)$ & pH & Salinity & $\mathbf{N a}^{+}$ & $\mathrm{Mg}^{2+}$ & $\mathbf{K}^{+}$ & $\mathrm{Ca}^{2+}$ & $\mathrm{Cl}^{-}$ & $\mathrm{SO}_{4}{ }^{2-}$ & Alka & DO \\
\hline RFGW & FPU-MZL & 17-Oct-05 & 24.57 & 7.65 & 22.87 & 7540 & 822 & 249 & 326 & 13000 & 1400 & 170 & 3.54 \\
\hline RFGW & FPU-MZU & 19-Apr-05 & 23.61 & 8.14 & 1.92 & 494 & 84.3 & 19.6 & 71.4 & 990 & 190 & 160 & 3.18 \\
\hline RFGW & FPU-MZU & 29-Jun-05 & 24.78 & 8.65 & 1.77 & 477 & 73.6 & 18.5 & 32.6 & 1000 & 140 & 91 & 0.16 \\
\hline RFGW & I75-MZ1 & $1-F e b-05$ & 26.9 & 8.28 & 2.91 & 834 & 124 & 34.3 & 115 & 1600 & 460 & 146 & 0.6 \\
\hline RFGW & I75-MZ1 & 27-Apr-05 & 25.94 & 8.01 & 5.07 & 833 & 134 & 34 & 121 & 1500 & 480 & 160 & 0.02 \\
\hline RFGW & I75-MZ1 & 22-Jun-05 & 25.68 & 8.04 & 2.98 & 813 & 124 & 31.9 & 103 & 1500 & 2300 & 140 & 0.02 \\
\hline RFGW & I75-MZ1 & $3-O c t-05$ & 27.94 & 7.83 & 2.87 & 885 & 138 & 42.2 & 125 & 1500 & 410 & 140 & 0.24 \\
\hline RFGW & I75-MZ1 & 28-Dec-05 & 27.79 & 8.01 & 3.05 & 876 & 142 & 33.8 & 130 & 1500 & 490 & 140 & 0.65 \\
\hline RFGW & I75-MZ2 & 31-Jan-05 & 28.28 & 7.4 & 6.97 & 1960 & 250 & 63.1 & 219 & 3800 & 620 & 156 & 0.49 \\
\hline RFGW & I75-MZ2 & 11-Apr-05 & 29.28 & 7.46 & 7.27 & 2090 & 260 & 67.2 & 224 & 4300 & 650 & 160 & 0.12 \\
\hline RFGW & I75-MZ2 & 11-Jul-05 & 27.31 & 8.8 & 6.51 & 1920 & 223 & 60.7 & 137 & 3600 & 530 & 38 & 0.09 \\
\hline RFGW & I75-MZ2 & 3-Oct-05 & 29.14 & 7.36 & 7.27 & 2180 & 284 & 67.6 & 260 & 4300 & 580 & 180 & 0.48 \\
\hline RFGW & I75-MZ2 & 28-Dec-05 & 28.11 & 7.61 & 7.53 & 2090 & 248 & 62.2 & 215 & 3800 & 590 & 180 & 0.14 \\
\hline RFGW & I75-MZ3 & 31-Jan-05 & 29.16 & 7.38 & 34.84 & 11200 & 1150 & 363 & 487 & 20000 & 2900 & 104 & 0.68 \\
\hline RFGW & I75-MZ3 & 11-Apr-05 & 29.74 & 7.52 & 34.28 & 11000 & 1270 & 382 & 516 & 20000 & 2800 & 100 & 0.22 \\
\hline RFGW & I75-MZ3 & 11-Jul-05 & 30.73 & 7.39 & 34.98 & 10900 & 1170 & 373 & 481 & 19000 & 4600 & 100 & 4.45 \\
\hline RFGW & I75-MZ3 & $3-O c t-05$ & 29.25 & 7.45 & 33.34 & 11200 & 1290 & 399 & 560 & 19000 & 3200 & 110 & 0.44 \\
\hline RFGW & I75-MZ3 & 28-Dec-05 & 31.39 & 7.47 & 34.89 & 10900 & 1290 & 401 & 547 & 20000 & 2700 & 120 & 4.94 \\
\hline RFGW & IWSD-MZ2 & 4-Feb-05 & 28.35 & 8.02 & 2.5 & 661 & 112 & 24.7 & 125 & 1300 & 520 & 111 & 0.11 \\
\hline RFGW & IWSD-MZ2 & 20-Apr-05 & 28.77 & 8.08 & 2.63 & 693 & 112 & 24.2 & 128 & 1200 & 550 & 110 & 5.13 \\
\hline
\end{tabular}


Table D 1 (Cont.)

\begin{tabular}{|c|c|c|c|c|c|c|c|c|c|c|c|c|c|}
\hline $\begin{array}{l}\text { Project } \\
\text { Code }\end{array}$ & Station ID & $\begin{array}{l}\text { Collected } \\
\text { date }\end{array}$ & $\mathbf{T}\left(\mathbf{C}^{\circ}\right)$ & pH & Salinity & $\mathrm{Na}^{+}$ & $\mathrm{Mg}^{2+}$ & $\mathbf{K}^{+}$ & $\mathrm{Ca}^{2+}$ & $\mathrm{Cl}^{-}$ & $\mathrm{SO}_{4}{ }^{2-}$ & Alka & DO \\
\hline RFGW & IWSD-MZ2 & 19-Sep-05 & 28.72 & 7.63 & 1.71 & 655 & 114 & 25.2 & 130 & 1000 & 390 & 110 & 1.71 \\
\hline RFGW & IWSD-MZ2 & 27-Dec-05 & 28.5 & 7.97 & 2.57 & 697 & 126 & 25.2 & 147 & 1200 & 500 & 130 & 0.16 \\
\hline RFGW & IWSD-MZ3 & 4-Feb-05 & 28.38 & 8.18 & 4.18 & 1140 & 197 & 39.8 & 180 & 2000 & 860 & 38 & 0.14 \\
\hline RFGW & IWSD-MZ3 & 20-Apr-05 & 24.48 & 8.09 & 4.32 & 1160 & 195 & 39 & 184 & 2000 & 880 & 120 & 0.96 \\
\hline RFGW & IWSD-MZ3 & 12-Jul-05 & 28.64 & 8.09 & 4.09 & 1080 & 180 & 38.5 & 162 & 2000 & 760 & 130 & 2.6 \\
\hline RFGW & IWSD-MZ3 & $6-O c t-05$ & 29.51 & 8.24 & 3.91 & 1100 & 196 & 35 & 190 & 1900 & 690 & 110 & 0.13 \\
\hline RFGW & IWSD-MZ3 & 27-Dec-05 & 28.51 & 8.63 & 3.78 & 1060 & 149 & 38.9 & 158 & 1900 & 550 & 28 & 0.36 \\
\hline RFGW & L-6433 & 27-May-05 & 28.38 & 7.25 & 2.8 & 652 & 127 & 22.4 & 149 & 1400 & 267 & 150 & 1.76 \\
\hline RFGW & L-6433 & 15-Jul-05 & 28.58 & 7.33 & 2.83 & 741 & 124 & 21.9 & 139 & 1500 & 330 & 130 & 0.18 \\
\hline RFGW & L-6436 & 15-Jul-05 & 27.11 & 6.98 & 24.84 & 7710 & 847 & 205 & 615 & 14000 & 1500 & 130 & 0.11 \\
\hline RFGW & L2-PW1 & 2-Feb-05 & 28.2 & 8.44 & 1.42 & 329 & 76.2 & 12.7 & 69.1 & 670 & 320 & 67 & 0.16 \\
\hline RFGW & L2-PW1 & 21-Apr-05 & 27.09 & 7.94 & 2.09 & 488 & 96.8 & 17.6 & 96.2 & 990 & 390 & 90 & 0.04 \\
\hline RFGW & L2-PW1 & 22-Jun-05 & 25.97 & 7.85 & 1.96 & 484 & 96 & 18 & 92 & 1000 & 1800 & 86 & 0.25 \\
\hline RFGW & L2-PW2 & 2-Feb-05 & 25.79 & 7.91 & 1.43 & 336 & 71.8 & 13.5 & 76.7 & 640 & 320 & 80 & 0.11 \\
\hline RFGW & L2-PW2 & 28-Apr-05 & 25.72 & 7.9 & 1.58 & 372 & 77.3 & 14.9 & 83.9 & 660 & 280 & 71 & 0.04 \\
\hline RFGW & L2-PW2 & 22-Jun-05 & 25.7 & 7.69 & 1.54 & 369 & 77 & 14.7 & 82.1 & 730 & 1500 & 83 & 0.26 \\
\hline RFGW & LAB-MZ2 & 3-Feb-05 & 29.85 & 8.04 & 1.19 & 282 & 64.2 & 13.5 & 68.2 & 460 & 310 & 83 & 5.2 \\
\hline RFGW & LAB-MZ2 & 19-Apr-05 & 28.84 & 8.03 & 1.22 & 277 & 64.6 & 13.5 & 68.6 & 460 & 360 & 80 & 0.02 \\
\hline
\end{tabular}


Table D 1 (Cont.)

\begin{tabular}{|c|c|c|c|c|c|c|c|c|c|c|c|c|c|}
\hline $\begin{array}{l}\text { Project } \\
\text { Code }\end{array}$ & Station ID & $\begin{array}{c}\text { Collected } \\
\text { date }\end{array}$ & $\mathbf{T}\left(\mathbf{C}^{\circ}\right)$ & pH & Salinity & $\mathbf{N a}^{+}$ & $\mathrm{Mg}^{2+}$ & $\mathbf{K}^{+}$ & $\mathrm{Ca}^{2+}$ & $\mathrm{Cl}^{-}$ & $\mathrm{SO}_{4}{ }^{2-}$ & Alka & DO \\
\hline RFGW & LAB-MZ2 & 22-Jun-05 & 30.06 & 7.94 & 1.18 & 282 & 64.6 & 14 & 69.6 & 490 & 1600 & 87 & 0.31 \\
\hline RFGW & LAB-MZ2 & 28-Dec-05 & 29.65 & 7.94 & 1.18 & 267 & 61.6 & 12.9 & 67.3 & 460 & 350 & 94 & 0.08 \\
\hline RFGW & LAB-MZ3 & $3-F e b-05$ & 31.82 & 7.49 & 16.62 & 4830 & 604 & 164 & 501 & 9500 & 1800 & 85 & 0.38 \\
\hline RFGW & LAB-MZ3 & 27-Apr-05 & 31.91 & 7.39 & 16.93 & 4870 & 614 & 154 & 511 & 9800 & 1700 & 87 & 0.02 \\
\hline RFGW & LAB-MZ3 & 22-Jun-05 & 31.19 & 7.27 & 15.46 & 4610 & 587 & 147 & 497 & 8900 & 1800 & 94 & 0.85 \\
\hline RFGW & LAB-MZ3 & 28-Dec-05 & 31.77 & 7.32 & 15.89 & 4780 & 637 & 152 & 547 & 8500 & 1800 & 91 & 0.07 \\
\hline RFGW & MF-52 & 9-Feb-05 & 28.26 & 7.47 & 2.18 & 549 & 85.2 & 18.1 & 102 & 1100 & 230 & 140 & 0.71 \\
\hline RFGW & MF-52 & 19-Apr-05 & 28.78 & 7.57 & 2.24 & 594 & 88 & 19.2 & 107 & 1100 & 210 & 150 & 0.01 \\
\hline RFGW & MF-52 & 29-Jun-05 & 28.86 & 7.37 & 2.19 & 577 & 88.7 & 19.4 & 105 & 1000 & 240 & 150 & 0.09 \\
\hline RFGW & MF-52 & 21-Sep-05 & 28.61 & 7.26 & 2.06 & 582 & 89 & 19.4 & 110 & 960 & 210 & 160 & 0.25 \\
\hline RFGW & MIU-MZ1 & 2-Feb-05 & 27.65 & 8.17 & 27.99 & 8520 & 957 & 295 & 388 & 15000 & 2100 & 36 & 1.45 \\
\hline RFGW & MIU-MZ1 & 12-Apr-05 & 28.07 & 8.45 & 27.43 & 8360 & 966 & 282 & 368 & 15000 & 2100 & 34 & 0.07 \\
\hline RFGW & MIU-MZ1 & 12-Jul-05 & 29.21 & 7.57 & 27.95 & 8490 & 969 & 295 & 472 & 14000 & 2000 & 90 & 0.11 \\
\hline RFGW & MIU-MZ1 & 29-Dec-05 & 28.18 & 8.01 & 27.34 & 8550 & 989 & 272 & 470 & 16000 & 2100 & 64 & 0.19 \\
\hline RFGW & MIU-MZ2 & 2-Feb-05 & 29.64 & 7.2 & 33.98 & 11200 & 1110 & 368 & 601 & 20000 & 2700 & 112 & 0.29 \\
\hline RFGW & MIU-MZ2 & 12-Apr-05 & 30.5 & 7.34 & 33.77 & 10400 & 1150 & 365 & 607 & 19000 & 2700 & 110 & 0.11 \\
\hline RFGW & MIU-MZ2 & 12-Jul-05 & 31.44 & 7.14 & 34.24 & 10600 & 1170 & 398 & 630 & 19000 & 2600 & 110 & 0.11 \\
\hline RFGW & MIU-MZ2 & 29-Dec-05 & 28.62 & 7.47 & 33.54 & 10800 & 1190 & 333 & 655 & 20000 & 2500 & 130 & 0.12 \\
\hline RFGW & NMC-MZL & 20-Apr-05 & 24.65 & 7.96 & 35.03 & 10600 & 1180 & 329 & 365 & 20000 & 2400 & 140 & 0.51 \\
\hline
\end{tabular}


Table D 1 (Cont.)

\begin{tabular}{|c|c|c|c|c|c|c|c|c|c|c|c|c|c|}
\hline $\begin{array}{l}\text { Project } \\
\text { Code }\end{array}$ & Station ID & $\begin{array}{c}\text { Collected } \\
\text { date }\end{array}$ & $\mathbf{T}\left(\mathbf{C}^{\circ}\right)$ & pH & Salinity & $\mathbf{N a}^{+}$ & $\mathrm{Mg}^{2+}$ & $\mathbf{K}^{+}$ & $\mathrm{Ca}^{2+}$ & $\mathrm{Cl}^{-}$ & $\mathrm{SO}_{4}{ }^{2-}$ & Alka & DO \\
\hline RFGW & NMC-MZL & 29-Jun-05 & 25.16 & 7.94 & 33.88 & 10600 & 1140 & 324 & 316 & 17000 & 2400 & 140 & 1.07 \\
\hline RFGW & NMC-MZL & 17-Oct-05 & 25.14 & 7.7 & 24.4 & 8470 & 946 & 292 & 345 & 16000 & 1800 & 150 & 1.65 \\
\hline RFGW & NMC-MZU & 20-Apr-05 & 24.69 & 7.89 & 1.99 & 484 & 96.8 & 20.4 & 78.6 & 1100 & 200 & 160 & 0.05 \\
\hline RFGW & NMC-MZU & 29-Jun-05 & 24.88 & 7.74 & 1.94 & 462 & 91 & 20 & 70.3 & 990 & 210 & 160 & 0.18 \\
\hline RFGW & NMC-MZU & 17-Oct-05 & 24.78 & 7.51 & 1.87 & 490 & 97.4 & 21 & 76.5 & 950 & 190 & 170 & 2 \\
\hline RFGW & OKF-42 & 8-Feb-05 & 25.55 & 7.6 & 0.36 & 38.5 & 46.6 & 9.8 & 52.2 & 54 & & 182 & 0.22 \\
\hline RFGW & OKF-42 & 28-Apr-05 & 26.4 & 7.69 & 0.36 & 39.3 & 39 & 5.1 & 34.7 & 54 & 90 & 190 & 0.08 \\
\hline RFGW & $\mathrm{OKF}-42$ & 21-Jun-05 & 26.54 & 7.53 & 0.35 & 40.4 & 38.5 & 4.74 & 36.9 & 52 & 120 & 180 & 0.56 \\
\hline RFGW & OKF-42 & 10-Oct-05 & 26.27 & 7.80 & 0.35 & 40.4 & 38.1 & 5.1 & 36.2 & 50 & 97 & 190 & 0.13 \\
\hline RFGW & OSF-100 & 7-Feb-05 & 23.11 & 8.19 & 0.15 & - & 9.03 & 2.01 & 37.1 & 4.5 & 68 & 62 & 0.32 \\
\hline RFGW & OSF-100 & 28-Apr-05 & 23.4 & 8.31 & 0.14 & - & 9.34 & 2.52 & 38.7 & 6.8 & 56 & 74 & 0.36 \\
\hline RFGW & OSF-100 & 1-Jul-05 & 23.38 & 8.09 & 0.15 & - & 9.3 & 1.44 & 38.7 & 4.2 & 64 & 72 & 3.95 \\
\hline
\end{tabular}


Table D 2 Florida aquifer quality data collected during year 2006. Salinity in ppt (\%o), major ion concentrations in mg/L (DBHYDRO)

\begin{tabular}{|c|c|c|c|c|c|c|c|c|c|c|c|c|c|}
\hline $\begin{array}{l}\text { Project } \\
\text { Code }\end{array}$ & Station ID & $\begin{array}{c}\text { Collected } \\
\text { date }\end{array}$ & $\mathrm{T}\left(\mathbf{C}^{\circ}\right)$ & pH & Salinity & $\mathbf{N a}+$ & $\mathrm{Mg}^{2+}$ & $\mathbf{K}^{+}$ & $\mathrm{Ca}^{2+}$ & $\mathrm{Cl}^{-}$ & $\mathrm{SO}_{4}{ }^{2-}$ & Alka & DO \\
\hline RFGW & BICY-MZ1 & 27-Mar-06 & 27.89 & 8.86 & 3.35 & 977 & 129 & 45.3 & 71.8 & 1900 & 470 & 100 & 0.11 \\
\hline RFGW & BICY-MZ1 & 15-Jun-06 & 29.15 & 8.81 & 3.66 & 1080 & 121 & 45 & 43 & 1700 & 390 & 48 & 0.92 \\
\hline RFGW & BICY-MZ1 & 24-Oct-06 & 26.92 & 9.28 & 3.96 & 1200 & 140 & 44 & 59 & 1900 & 450 & 50 & 7.16 \\
\hline RFGW & BICY-MZ2 & 27-Mar-06 & 28.11 & 7.68 & 5.2 & 1460 & 179 & 60.9 & 147 & 2700 & 720 & 160 & 0.15 \\
\hline RFGW & BICY-MZ2 & 24-Oct-06 & 26.66 & 7.67 & 3.64 & 1100 & 130 & 43 & 120 & 1700 & 520 & 160 & 6.28 \\
\hline RFGW & BICY-MZ3 & 27-Mar-06 & 28.29 & 7.36 & 27.15 & 8000 & 845 & 256 & 562 & 17000 & 1400 & 140 & 0.11 \\
\hline RFGW & BICY-MZ3 & 15-Jun-06 & 28.63 & 7.46 & 27.14 & 9180 & 911 & 284 & 617 & 16000 & 1500 & 140 & 0.08 \\
\hline RFGW & BICY-MZ4 & 27-Mar-06 & 30.77 & 6.76 & 26.71 & 10900 & 1160 & 408 & 808 & 21000 & 2700 & 190 & 0.4 \\
\hline RFGW & BICY-MZ4 & 15-Jun-06 & 31.02 & 6.89 & 34.16 & 11100 & 1120 & 407 & 786 & 20000 & 2700 & 190 & 0.46 \\
\hline RFGW & BRY-MW & 30-Mar-06 & 25 & 7.5 & 2.46 & & & & 125 & 1300 & 390 & 110 & 0.19 \\
\hline RFGW & BRY-MW & 28-Jun-06 & 29.78 & 7.67 & 2.63 & 626 & 114 & 25 & 140 & 1300 & 430 & 120 & 0.19 \\
\hline RFGW & BRY-MW & 25-Sep-06 & 30.1 & 7.55 & 2.59 & 640 & 120 & 27 & & 1300 & 410 & 100 & 0.35 \\
\hline RFGW & BSU-MZL & 30-Mar-06 & 29.5 & 7.5 & 32.94 & & & & & 20000 & 400 & 120 & 3.04 \\
\hline RFGW & BSU-MZL & 22-Jun-06 & 32.97 & 7.45 & 33.66 & 10700 & 1100 & 392 & & 19000 & 2800 & 120 & 0.42 \\
\hline RFGW & BSU-MZL & 31-Oct-06 & 31.83 & 7.19 & 32.41 & 11000 & 1200 & 540 & 671 & 20000 & 2700 & 110 & 1.95 \\
\hline RFGW & BSU-MZU & 30-Mar-06 & 32.95 & 7.52 & 1.5 & & & & 740 & 760 & 230 & 140 & 0.16 \\
\hline RFGW & BSU-MZU & 22-Jun-06 & 32.3 & 7.4 & 1.53 & 358 & 86.7 & 17 & & 710 & 260 & 140 & 0.19 \\
\hline
\end{tabular}


Table D 2 (Cont.)

\begin{tabular}{|c|c|c|c|c|c|c|c|c|c|c|c|c|c|}
\hline $\begin{array}{c}\text { Project } \\
\text { Code }\end{array}$ & Station ID & $\begin{array}{l}\text { Collected } \\
\text { date }\end{array}$ & $\mathbf{T}\left(\mathbf{C}^{\circ}\right)$ & pH & Salinity & $\mathrm{Na}+$ & $\mathrm{Mg}^{2+}$ & $\mathbf{K}^{+}$ & $\mathrm{Ca}^{2+}$ & $\mathrm{Cl}^{-}$ & $\mathrm{SO}_{4}{ }^{2-}$ & Alka & DO \\
\hline RFGW & BSU-MZL & 31-Oct-06 & 31.83 & 7.19 & 32.41 & 11000 & 1200 & 540 & 671 & 20000 & 2700 & 110 & 1.95 \\
\hline RFGW & BSU-MZU & 30-Mar-06 & 32.95 & 7.52 & 1.5 & & & & 740 & 760 & 230 & 140 & 0.16 \\
\hline RFGW & BSU-MZU & 22-Jun-06 & 32.3 & 7.4 & 1.53 & 358 & 86.7 & 17 & & 710 & 260 & 140 & 0.19 \\
\hline RFGW & BSU-MZU & 31-Oct-06 & 32.19 & 7.61 & 1.57 & 370 & 89.1 & 18 & & 760 & 240 & 170 & 8.75 \\
\hline RFGW & DF-4 & 11-Apr-06 & 21.8 & 7.68 & 3.43 & 1110 & 158 & 40.3 & 129 & 1900 & 540 & 130 & 0.08 \\
\hline RFGW & DF-4 & 9-Jun-06 & 22.69 & 8.01 & 3.45 & 1030 & 120 & 36 & 100 & 1770 & 522 & 130 & 0.51 \\
\hline RFGW & DF-4 & 13-Oct-06 & 22.55 & 7.59 & 3.43 & 968 & 130 & 36 & 110 & 1900 & 570 & 130 & 3.04 \\
\hline RFGW & DF-5 & 11-Jan-06 & 23.16 & 10.18 & 3.02 & 921 & 60.7 & 40 & 154 & 1600 & 428 & -5 & 0.13 \\
\hline RFGW & DF-5 & 11-Apr-06 & 22.75 & 9.6 & 3.06 & 1060 & 77.5 & 50.8 & 164 & 1700 & 460 & 9 & 0.06 \\
\hline RFGW & DF-5 & 13-Oct-06 & 23.56 & 9.57 & 3.08 & 883 & 68 & 42 & 150 & 1700 & 500 & 12 & 2.41 \\
\hline RFGW & ENP-100 & 12-Jan-06 & 27.89 & 7.5 & 5.1 & 1590 & 183 & 59 & 164 & 2810 & 469 & 170 & 0.37 \\
\hline RFGW & ENP-100 & 29-Mar-06 & 28.04 & 7.4 & 5.06 & 1470 & 177 & 60 & 156 & 3400 & 580 & 170 & 0.13 \\
\hline RFGW & ENP-100 & 8-Jun-06 & 28.07 & 7.5 & 5.19 & 1580 & 157 & 61 & 140 & 2790 & 477 & 170 & 0.22 \\
\hline RFGW & ENP-100 & 13-Oct-06 & 28.29 & 7.23 & 5.22 & 1440 & 170 & 59 & 160 & 3200 & 550 & 160 & 4.58 \\
\hline RFGW & FPU-MZL & 15-Mar-06 & 24.44 & 8.1 & 22.96 & 6570 & 787 & 247 & 307 & 14000 & 1600 & 160 & 0.22 \\
\hline RFGW & FPU-MZL & 1-Jun-06 & 24.51 & 7.78 & 22.95 & 6700 & 790 & 270 & 310 & 13000 & 1700 & 160 & 1.22 \\
\hline
\end{tabular}


Table D 2 (Cont.)

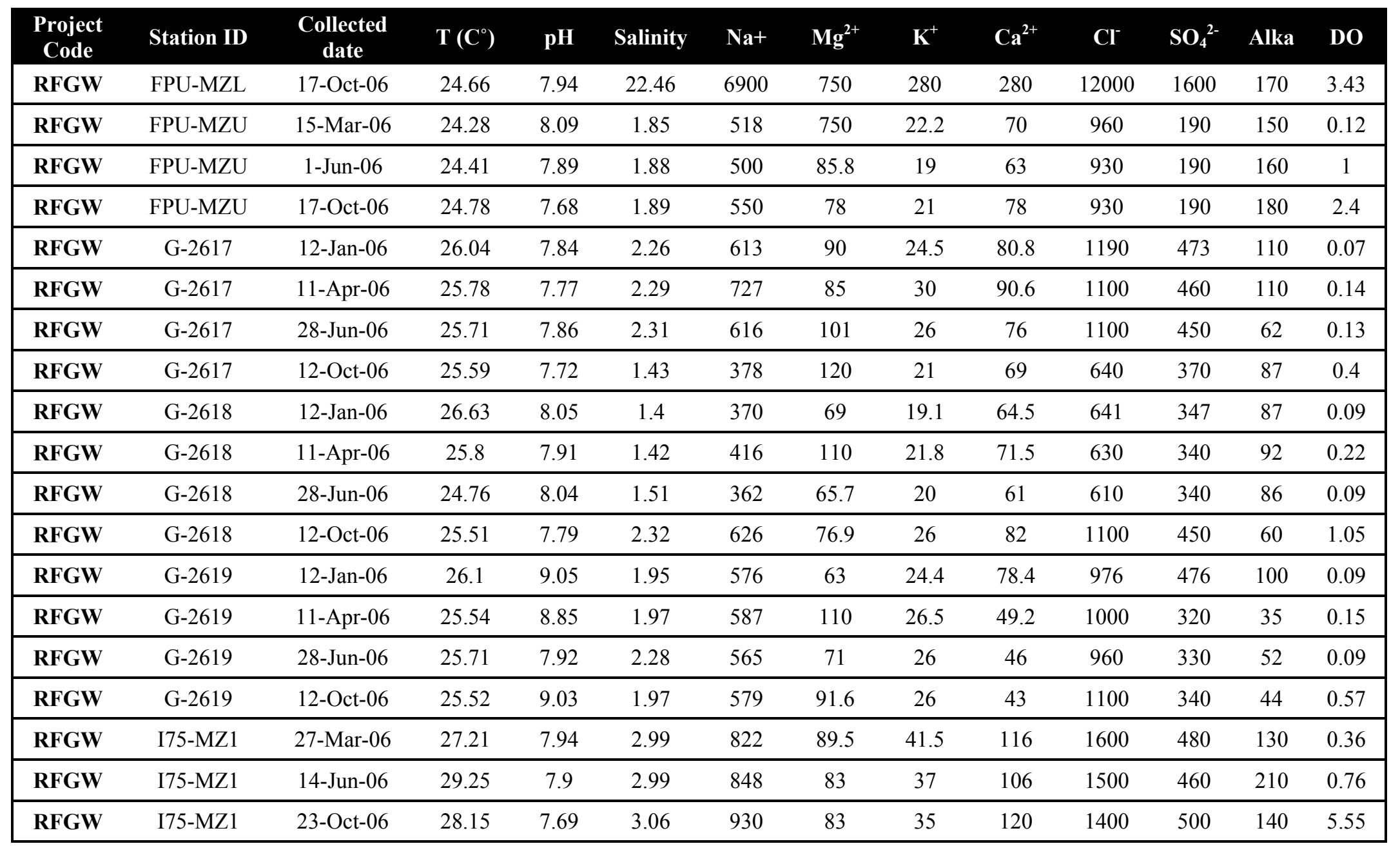


Table D 2 (Cont.)

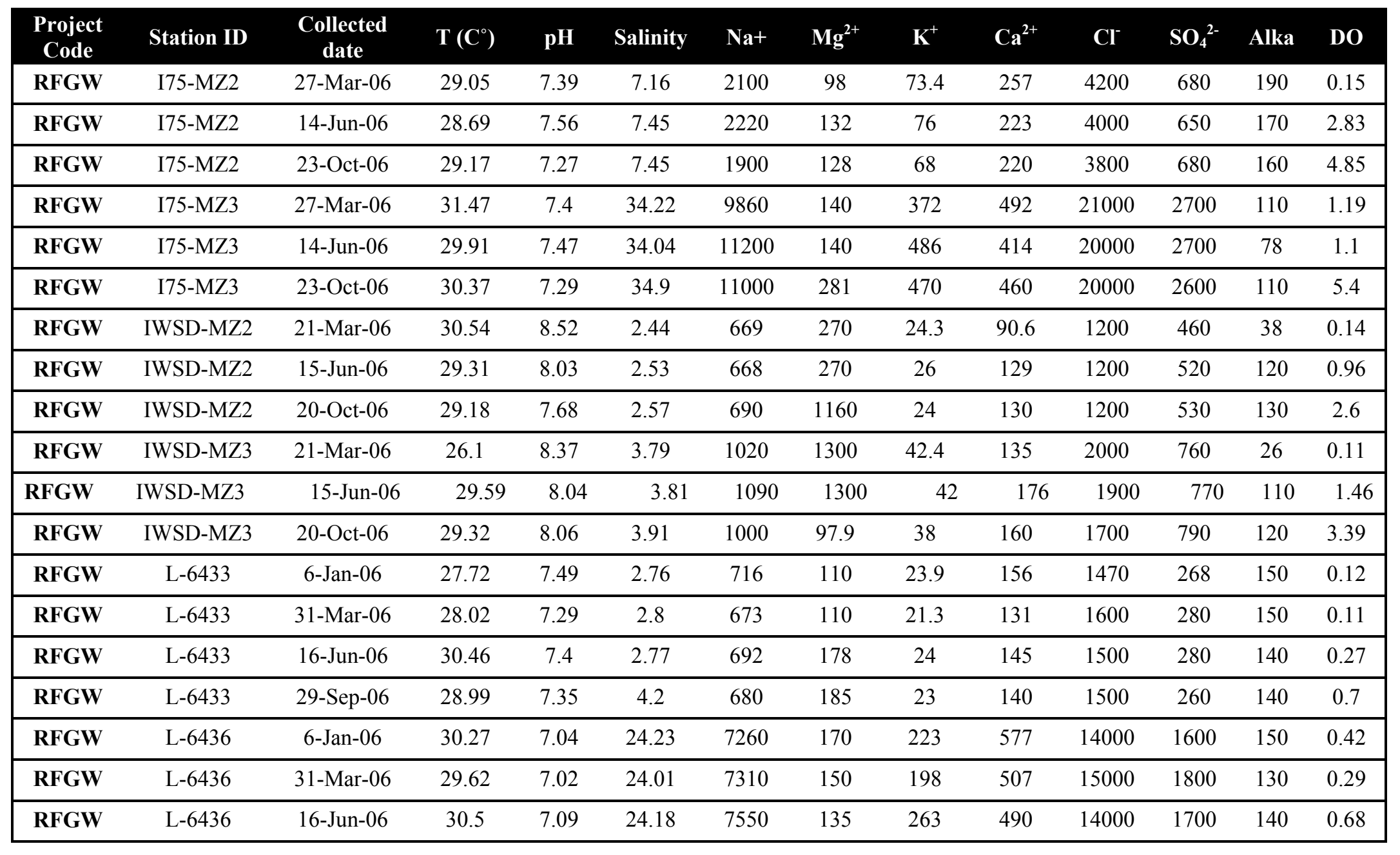


Table D 2 (Cont.)

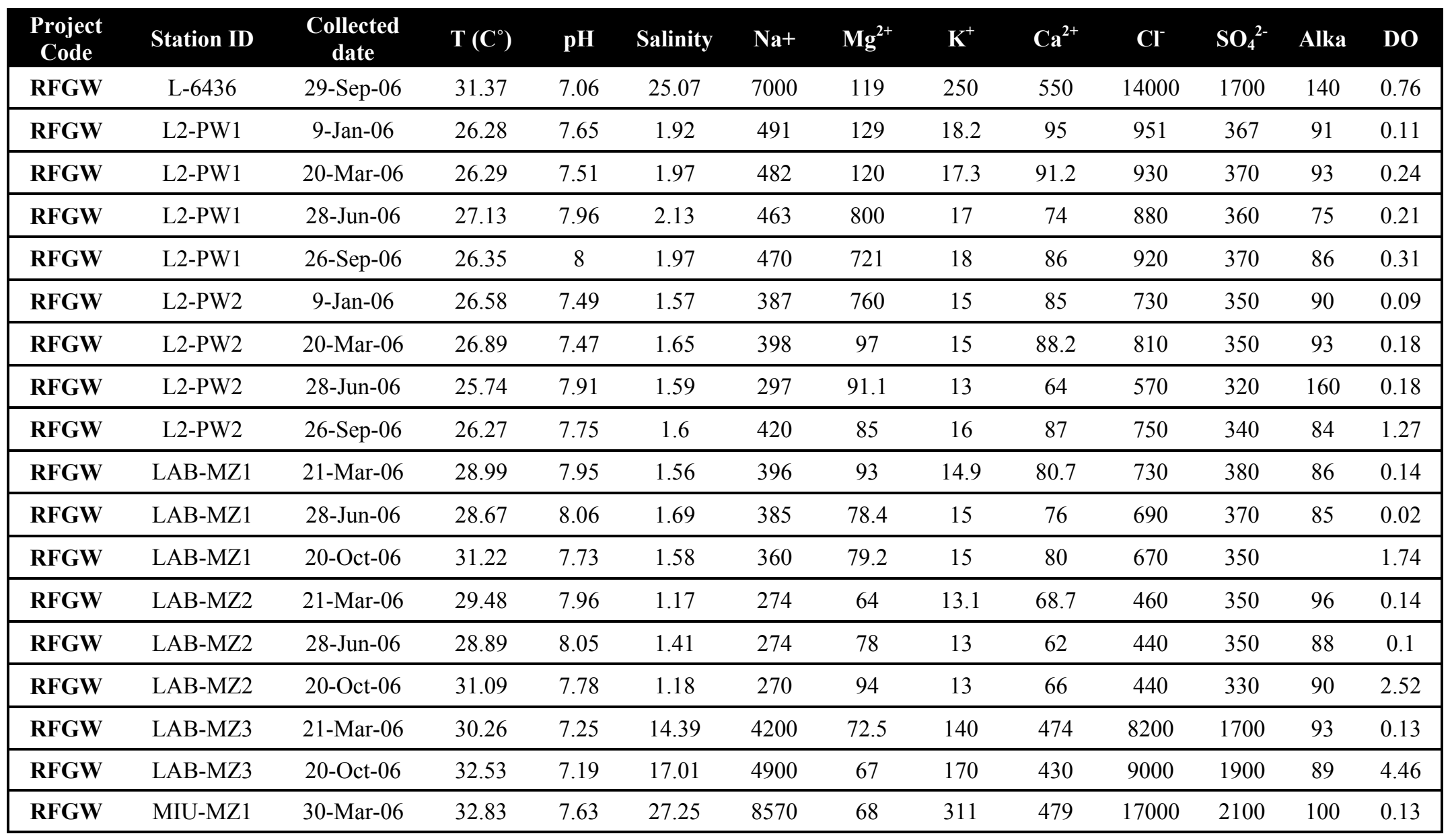


Table D 2 (Cont.)

\begin{tabular}{|c|c|c|c|c|c|c|c|c|c|c|c|c|c|}
\hline $\begin{array}{l}\text { Project } \\
\text { Code }\end{array}$ & Station ID & $\begin{array}{l}\text { Collected } \\
\text { date }\end{array}$ & $\mathbf{T}\left(\mathbf{C}^{\circ}\right)$ & pH & Salinity & $\mathbf{N a}+$ & $\mathrm{Mg}^{2+}$ & $\mathbf{K}^{+}$ & $\mathrm{Ca}^{2+}$ & $\mathrm{Cl}^{-}$ & $\mathrm{SO}_{4}{ }^{2-}$ & Alka & DO \\
\hline RFGW & MIU-MZ1 & 14-Jun-06 & 29.08 & 7.63 & 27.17 & 8710 & 62.2 & 349 & 358 & 16000 & 2100 & 76 & 3.02 \\
\hline RFGW & MIU-MZ1 & 23-Oct-06 & 28.43 & 8.08 & 27.9 & 8200 & 59 & 340 & 400 & 16000 & 2100 & 40 & 0.2 \\
\hline RFGW & MIU-MZ2 & 30-Mar-06 & 36.59 & 7.35 & 33.5 & 8600 & 60 & & & 21000 & 2600 & 120 & 0.1 \\
\hline RFGW & MIU-MZ2 & 14-Jun-06 & 33.84 & 7.29 & 33.38 & 11200 & 540 & 469 & 470 & 19000 & 2600 & 120 & \\
\hline RFGW & NMC-MZL & 15-Mar-06 & 25.16 & 7.98 & 33.24 & 9750 & 963 & 349 & 383 & 20000 & 2400 & 150 & 0.08 \\
\hline RFGW & NMC-MZL & 31-May-06 & 26.13 & 7.82 & 33.5 & 4900 & 950 & 200 & 200 & 14000 & 48 & 150 & 4.08 \\
\hline RFGW & NMC-MZL & 26-Oct-06 & 24.93 & 8.23 & 22.94 & 9800 & 940 & 440 & 380 & 19000 & 2400 & 140 & 2.86 \\
\hline RFGW & NMC-MZU & 15-Mar-06 & 24.72 & 7.71 & 1.91 & 496 & 1120 & 21.6 & 76.2 & 1000 & 200 & 160 & 0.06 \\
\hline RFGW & NMC-MZU & 31-May-06 & 26.89 & 8.05 & 2.03 & 470 & 1200 & 22 & 73 & 960 & 220 & 160 & 4.9 \\
\hline RFGW & OKF-42 & 17-Mar-06 & 25.51 & 7.47 & 0.35 & 38.5 & 1090 & 5.4 & 30.8 & 54 & 87 & 190 & 0.25 \\
\hline RFGW & OKF-42 & 4-Jun-06 & 25.73 & 7.59 & 0.43 & 41 & 600 & 6.2 & 30 & 55 & 72 & 200 & 1.05 \\
\hline RFGW & $\mathrm{OKF}-42$ & 3-Oct-06 & 26.73 & 7.57 & 0.34 & 38 & 1100 & 4.7 & 35 & 52 & 99 & 190 & 0.59 \\
\hline RFGW & OSF-100 & 8-Jan-06 & 23.2 & 8.27 & 0.14 & 3.23 & 91 & 1.87 & 39.1 & 4.6 & 64 & 77 & 0.64 \\
\hline RFGW & OSF-100 & 16-Mar-06 & 21.7 & 7.86 & 0.14 & 4.01 & 100 & 2.61 & 37.3 & 5.7 & 67 & 72 & 1.88 \\
\hline RFGW & OSF-100 & 30-Jun-06 & 23.2 & 8.06 & 0.24 & 3.2 & 38.4 & 1.6 & 36 & 9.4 & 66 & 70 & 3.76 \\
\hline RFGW & OSF-100 & 5-Oct-06 & 23.68 & 7.93 & 0.14 & 3.4 & 34 & 1.7 & 39 & 4.4 & 67 & 70 & 3.7 \\
\hline
\end{tabular}




\section{APPENDIX E}

\section{EFPC Soil Physical and Chemical Characteristics}

The Oak Ridge Reservation (ORR) (Figure E 1) was built as a part of Manhattan Project to develop the nuclear weapons during World War II in Tennessee, USA, in 1942. There were four plants constructed in ORR: K-25, S-50, Y-12 and X-10. X-10 plant is now known as Oak Ridge National Laboratory (ORNL). During 1940s-1950s, the Lithium isotope separation was performed at Y-12 plant. The separation using lithium amalgam which $\mathrm{Li}$ dissolved in $\mathrm{Hg}$. As a result 11 million $\mathrm{kg}$ of $\mathrm{Hg}$ were used and more than $200,000 \mathrm{~kg}$ of $\mathrm{Hg}$ were accidentally released to the environment.

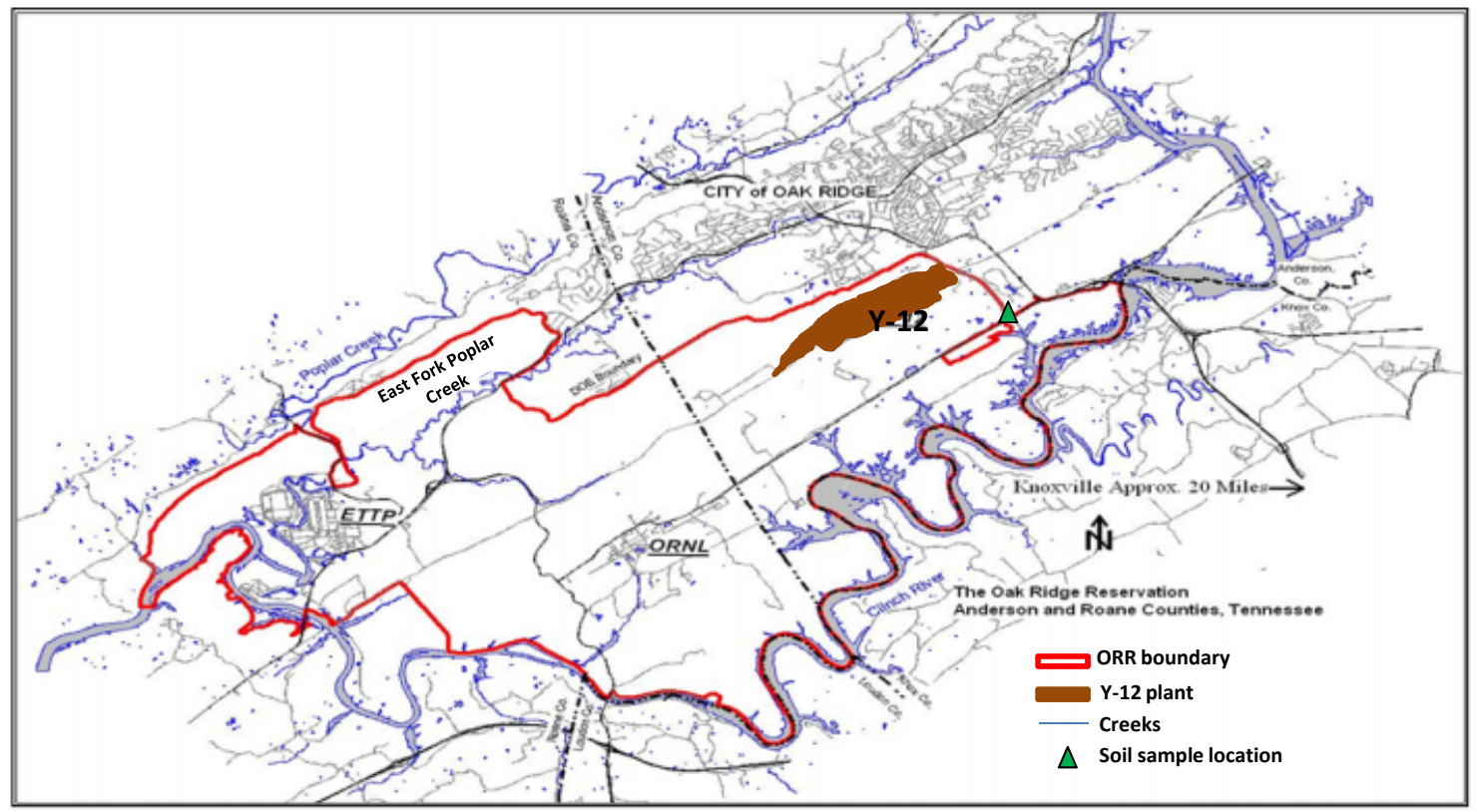

Figure E 1 Map of ORR and soil sample location (modified after www.esd.ornl.gov)

The released $\mathrm{Hg}$ was found accumulated in soil, sediment, bedrock which are continued sources for East Fork Poplar Creek (EFPC) that locates downstream of the Y-12 plant. The high concentration of $\mathrm{Hg}$ in EFPC raised the public concern on wild life and human health on contacting the contaminated water. Many attempts and remediation plans are 
made to remove and reduce the $\mathrm{Hg}$ concentration in the creek. To best understand the fate and transport of $\mathrm{Hg}$ in the creek, the EFPC soil physical and chemical property data which play important role to $\mathrm{Hg}$ fate and transport were collected and described in this section.

The ORR soils are found consisted of properties sandstone, siltstone, and limestone. In this section the soil properties collected from Driese et al., 2001 are categorized by the type of soil described in Table E 1 - E 4 for top soil, sandstone, siltstone, and limestone respectively

Table E 1Top soil property (Driese et al., 2001)

\begin{tabular}{|cc|}
\hline Parameter & Soil Property \\
\hline Geologic/Pedologic Material & $\begin{array}{c}\text { Soil Zone (A and Bw horizons); thin } \\
(20-60 \mathrm{~cm}), \text { loamy-skeletal, mixed, } \\
\text { thermic, Typic Dystrochrept (Soil Survey } \\
\text { Staff } 1990)\end{array}$ \\
\hline Detrital Mineralogy & $\begin{array}{c}40-60 \% \text { monocrystalline quartz; } 2 \% \\
\text { glauconite; } 2-5 \% \mathrm{~K} \text {-feldspar; }, 1- \\
2 \% \text { plagioclase; }, 2 \% \text { muscovite } 1 \\
\text { biotite; }, 1 \% \text { carbonate allochems; } \\
, 2 \% \text { heavy minerals }\end{array}$ \\
\hline Pedogenic Features & $\begin{array}{c}25-40 \% \text { lithorelicts (saprolite clasts); } \\
2-6 \% \text { Fe/Mn-oxide/oxyhydroxide } \\
\text { glaebules; } 1-20 \% \text { very coarse to fine } \\
\text { roots; }, 1 \% \text { pedogenic clay }\end{array}$ \\
\hline Matrix Porosity & $\begin{array}{c}\text { Very high (40-50\%), mostly intergranular } \\
\text { and in root charnels; decreases } \\
\text { progressively downward to contact } \\
\text { with saprolite }\end{array}$ \\
\hline Fracture Porosity & $\begin{array}{c}\text { None; no soil fractures are apparent in } \\
\text { field or in thin section }\end{array}$ \\
\hline
\end{tabular}


Table E 2 Sandstone soil property (Driese et al., 2001)

\begin{tabular}{|c|c|}
\hline Parameter & Soil Property \\
\hline Geologic/Pedologic Material & $\begin{array}{l}\text { Sandstone saprolite derived from weathering } \\
\text { of fractured, very fine-grained, } \\
\text { parallel- to ripple cross-laminated, } \\
\text { glauconitic, peloidal, feldspathic } \\
\text { quartz arenite; estimated } 20 \% \text { of saprolite } \\
\text { section }\end{array}$ \\
\hline Detrital Mineralogy & $\begin{array}{c}55-65 \% \text { monocrystalline quartz; } 5-8 \% \\
\text { glauconite; } 5-10 \% \text { K-feldspar; }, 5 \% \\
\text { plagioclase; } 2-5 \% \text { muscovite } 1 \text { biotite; } \\
, 2 \% \text { carbonate allochems; } \\
, 2 \% \text { heavy minerals }\end{array}$ \\
\hline Pedogenic Features & $\begin{array}{l}\text { vadose pedogenic clay cements at detrital } \\
\text { grain contacts (meniscus) and on } \\
\text { undersides of grains (pendant); pedogenic } \\
\text { clay infillings of fractures; Fe/ } \\
\text { Mn oxide and oxyhydroxide coatings } \\
\text { on grain surfaces and in fractures; } \\
, 1 \% \text { roots }\end{array}$ \\
\hline Matrix Porosity & $\begin{array}{l}\text { High }(20-30 \%) \text {, mostly in intergranular } \\
\text { pores and to a lesser degree in dissolution } \\
\text { intragranular (grain moldic) } \\
\text { pores; matrix pore apertures range } \\
\text { from } 1-100 \mathrm{~mm} \text {, with modal size in } \\
\text { the } 20-50 \mathrm{~mm} \text { size range }\end{array}$ \\
\hline Fracture Porosity & $\begin{array}{c}\text { Few fracture pores }(, 5 \%) \text { unfilled } \\
\text { with pedogenic clays, with average } \\
\text { spacing of } 0.5-5 \mathrm{~cm} \text {; fracture apertures } \\
\text { (pre-clay infill) range from } 5.0 \\
\text { mm to } 0.5 \mathrm{~mm} \text {, but open fractures } \\
\text { range from } 1-10 \mathrm{~mm}\end{array}$ \\
\hline
\end{tabular}


Table E 3 Siltstone soil property (Driese et al., 2001)

\begin{tabular}{|c|c|}
\hline Parameter & Soil Property \\
\hline Geologic/Pedologic Material & $\begin{array}{l}\text { Siltstone/shale saprolite derived from } \\
\text { weathering of fractured, laminated to } \\
\text { weakly bioturbated, illitic to chloritic } \\
\text { clayey siltstone to silty shale; estimated } \\
50 \% \text { of saprolite section }\end{array}$ \\
\hline Detrital Mineralogy & $\begin{array}{c}\text { matrix consists of } 50-80 \% \text { illite, with } \\
\text { subordinate chlorite; } 10-30 \% \text { monocrystalline } \\
\text { quartz; } 5-10 \% \text { detrital biotite } \\
\text { and muscovite; }, 1 \% \text { glauconite; } \\
, 1 \% \text { heavy minerals }\end{array}$ \\
\hline Pedogenic Features & $\begin{array}{c}\text { abundant pedogenic clay random (disordered) } \\
\text { smectite/chlorite or smectite/ } \\
\text { vermiculite; pedogenic clay and } \\
\text { Fe/Mn oxide and oxyhydroxide porefillings } \\
\text { and coatings of fractures; } 2- \\
5 \% \text { roots }\end{array}$ \\
\hline Matrix Porosity & $\begin{array}{l}\text { Probably high }(30-50 \%) \text {, but cannot be } \\
\text { resolved with petrographic microscope; } \\
\text { matrix pore apertures probably } \\
, 1 \mathrm{~mm}\end{array}$ \\
\hline Fracture Porosity & $\begin{array}{l}\text { Common fracture pores }(10-20 \%) \text {, } \\
\text { with average spacing of } 0.5-3 \mathrm{~cm} \text {; } \\
\text { fracture apertures (pre-clay infill) } \\
\text { range from } 5.0 \mathrm{~mm} \text { to } 1.5 \mathrm{~mm} \text {, with } \\
\text { modal size of } 10-20 \mathrm{~mm} \text { for open } \\
\text { fracture pores }\end{array}$ \\
\hline
\end{tabular}


Table E 4 Limestone soil property (Driese et al., 2001)

\section{Parameter}

Soil Property

Geologic/Pedologic Material

Limestone saprolite derived from weathering of fractured, intraclastic rudstone to floatstone that consists of $0.5-10$ cm diameter, discoidal intraclasts comprised of sandy, peloidal and skeletal lime grainstone to packstone; estimated $30 \%$ of saprolite section

matrix consists of mixture of $80-90 \%$

illite and random (disordered) smectite/

Detrital Mineralogy chlorite; $10-40 \%$ monocrystalline quartz; $2-5 \%$ detrital biotite and muscovite; $95 \%$ glauconite; , $1 \%$ heavy minerals

\begin{tabular}{|c|c|}
\hline Pedogenic Features & $\begin{array}{c}\text { abundant pedogenic clay random (disordered) } \\
\text { smectite/chlorite or smectite/ } \\
\text { vermiculite; pedogenic clay and } \\
\text { Fe/Mn oxide and oxyhydroxide porefillings } \\
\text { and coatings of fractures; } 2- \\
5 \% \text { roots }\end{array}$ \\
\hline Matrix Porosity & $\begin{array}{l}\text { High (30-50\%), includes large root } \\
\text { pores (up to } 5 \mathrm{~mm} \text { ) in matrix, but } \\
\text { many other matrix pores cannot be } \\
\text { resolved with petrographic microscope; } \\
\text { most matrix pore apertures } \\
\text { probably ,5 mm }\end{array}$ \\
\hline Fracture Porosity & $\begin{array}{c}\text { Few fracture pores }(, 5 \%) \text { unfilled } \\
\text { with pedogenic clays, with average } \\
\text { spacing of } 0.5-5.0 \mathrm{~cm} \text {; fracture apertures } \\
\text { (pre-clay infill) range from } 5.0 \\
\text { mm to } 2 \mathrm{~mm}\end{array}$ \\
\hline
\end{tabular}


The EFPC soil properties were obtained from Han et al. (2012). The soil samples included EFPC floodplain surface soil $(n=23)$, EFPC bank soil $(n=3)$, sediment and sediment soil profile $(n=10)$. Han et al. (2012) reported that the soil samples were analyzed for their mineral compositions: $\mathrm{Fe}_{2} \mathrm{O}_{3}, \mathrm{Mn}$, and Carbon and the cation exchange capacity (CEC) (Table E 5). The soil Hg concentrations as cinnabar-Hg, noncinnabar-Hg, and total-Hg were also analyzed (Table E 6).

Table E 5 EFPC Soil composition (Han et al., 2012)

\begin{tabular}{|ccccccc|}
\hline Soil type & $\begin{array}{c}\text { Depth } \\
\mathbf{c m}\end{array}$ & $\begin{array}{c}\mathbf{F e}_{\mathbf{2}} \mathbf{O}_{\mathbf{3}} \\
\mathbf{\%}\end{array}$ & $\begin{array}{c}\mathbf{M n} \\
\mathbf{\%}\end{array}$ & $\begin{array}{c}\mathbf{C E C} \\
\mathbf{c m o l} / \mathbf{k g}\end{array}$ & $\begin{array}{c}\text { Carbon } \\
\mathbf{\%}\end{array}$ & $\begin{array}{c}\mathbf{p H} \\
\text { (range) }\end{array}$ \\
\hline Surface soil & $0-20$ & 2.45 & 0.11 & 18.50 & 4.44 & $7.04-7.46$ \\
\hline Sediment & - & 2.5 & 0.14 & 7.30 & 2.78 & 7.52 \\
\hline \multirow{2}{*}{ Bank soil } & 0.10 & 1.99 & 0.09 & 13.31 & 2.09 & $7.32-7.46$ \\
\cline { 2 - 7 } & $50-60$ & 2.91 & 0.08 & 6.96 & 1.29 & $7.40-7.84$ \\
\hline \multirow{2}{*}{$\begin{array}{c}\text { Sediment soil } \\
\text { profile }\end{array}$} & $0-10$ & 2.85 & 0.11 & 12.33 & 3.10 & $7.38-7.51$ \\
\cline { 2 - 7 } & $50-60$ & 2.15 & 0.08 & 11.33 & 1.34 & $7.37-7.99$ \\
\cline { 2 - 7 } & $100-110$ & 2.79 & 0.08 & 10.20 & 2.48 & $7.47-7.64$ \\
\hline
\end{tabular}


Table E 6 Concentrations of cinnabar mercury, non-cinnabar mercury and total mercury in bank soils and sediment of Lower East Fork Poplar Creek, Oak Ridge, TN obtained from Han et al. (2012)

\begin{tabular}{|c|c|c|c|c|c|c|c|}
\hline Soil Type & $\begin{array}{l}\text { Depth } \\
\mathrm{cm}\end{array}$ & & $\begin{array}{c}\text { Noncinnabar } \\
-\mathrm{Hg} \\
\mathbf{m g} / \mathbf{k g}\end{array}$ & $\begin{array}{c}\text { Cinnabar } \\
-\mathrm{Hg} \\
\mathrm{mg} / \mathrm{kg}\end{array}$ & $\begin{array}{c}\text { Total } \\
\mathbf{H g} \\
\mathbf{m g} / \mathbf{k g}\end{array}$ & $\begin{array}{c}\text { Noncinnabar } \\
-\mathrm{Hg} \\
\%\end{array}$ & $\begin{array}{c}\text { Cinnabar } \\
-\mathrm{Hg} \\
\%\end{array}$ \\
\hline \multirow{8}{*}{ Bank soil } & $0-10$ & Average & 51.4 & 1.0 & 52.3 & 98.2 & 1.8 \\
\hline & & $\begin{array}{l}\text { Standard } \\
\text { deviation }\end{array}$ & 4.7 & 0.7 & 5.3 & 1.1 & 1.1 \\
\hline & & Maximum & 56.3 & 1.7 & 58.1 & 98.9 & 3.0 \\
\hline & & Minimum & 47.0 & 0.5 & 47.5 & 97.0 & 1.1 \\
\hline & $50-60$ & Average & 23.2 & 17.9 & 41.1 & 63.0 & 37.0 \\
\hline & & $\begin{array}{l}\text { Standard } \\
\text { deviation }\end{array}$ & 26.9 & 28.5 & 20.0 & 53.9 & 53.9 \\
\hline & & Maximum & 52.9 & 50.8 & 53.9 & 98.2 & 99.0 \\
\hline & & Minimum & 0.5 & 1.0 & 18.1 & 1.0 & 1.8 \\
\hline Sediment & - & & 72.5 & 1.7 & 74.2 & 97.7 & 2.3 \\
\hline
\end{tabular}

It can be seen in Table E 5 that the EFPC soils evidentially consists of minerals which are potentially absorb the $\mathrm{Hg}$. $\mathrm{Fe}_{2} \mathrm{O}_{3}$ content in the bank soil increased with depth while there is no trend for sediment profile soil. Mn mineral concentrations show the decrease trend with depth for both bank and sediment profile soils.

Table E 6 shows the Hg concentrations in the EFPC soil, the data indicated that, for the bank soil, the noncinnabar-Hg decreases with depth while the cinnabar-Hg increases with depth. For the sediment soil, the $\mathrm{Hg}$ content is as high as $97.7 \mathrm{mg} / \mathrm{kg}$-soil and $97 \% \mathrm{Hg}$ content is noncinnabar-Hg. 


\section{APPENDIX F \\ ENP Soil Physical and Chemical Characteristics}

Everglades National Park (ENP), FL, is a unique wetland environment with a specific ecosystem and wildlife. The area consists of the freshwater, mangrove and brackish water. The major soil type of this area is peat soil, which consists of organic carbon, and different minerals (e.g., $\mathrm{S}$ mineral, $\mathrm{Fe}$ mineral and $\mathrm{CaCO}_{3}$ ). The soil characteristics (physical and chemical characteristics) of the Shark River Slough (SRS), SRS1 to SRS6 are the areas of concern for Hg transport (Figure F 1), collected from relevant literature and websites (i.e., DBHYDRO and Florida coastal everglades long term ecological research websites) are described in this section.

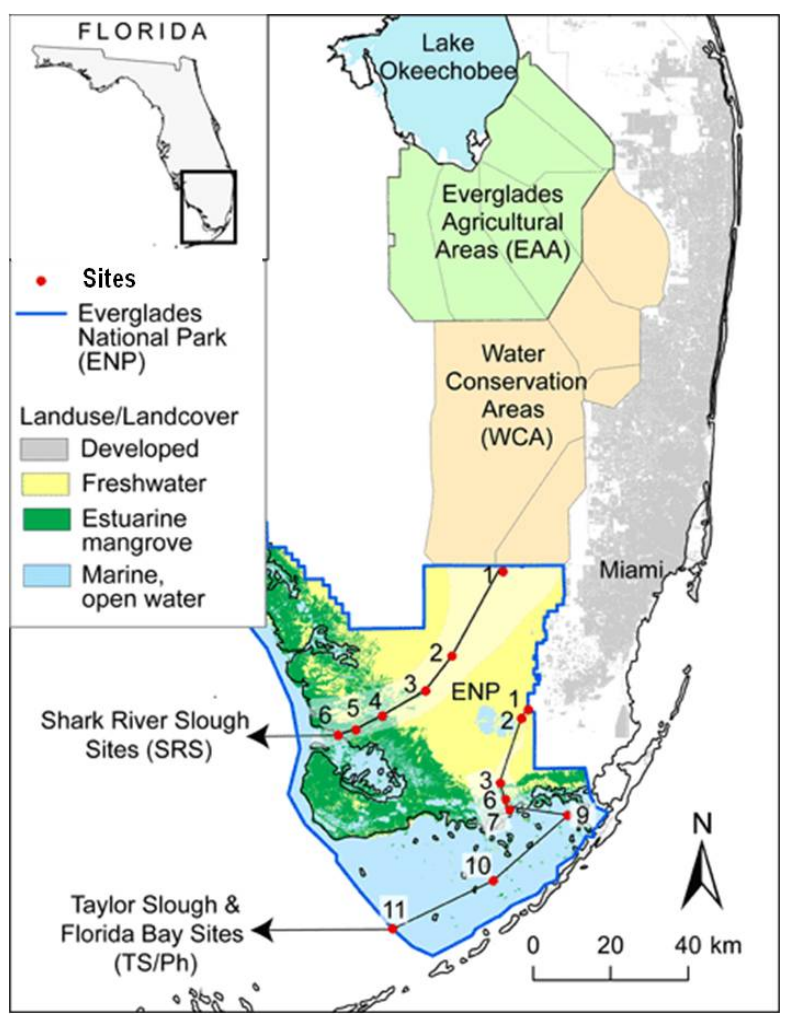

Figure F 1 Map of ENP and soil collection sites (modified after Florida coastal everglades long term ecological research website) 
The soil characteristics of SRS1 to SRS6 consist of organic, Fe and S minerals collected during $2004-2010$ are shown in Tables F 1 to F 6 respectively. The percentage of $\mathrm{CaCO}_{3}$ mineral content in soils of the sites (SRS1 to SRS6) collected during $2000-$ 2001 is shown in Table F 7.

Table F 1 SRS1 soil characteristics collected during 2004 - 2010 (DBHYDRO and Florida coastal everglades long term ecological research websites)

\begin{tabular}{|c|c|c|c|c|}
\hline Date & $\underset{\mathrm{g} / \mathrm{cc}}{\boldsymbol{\rho}_{\mathrm{b}}}$ & $\begin{array}{c}\text { Organics } \\
\%\end{array}$ & $\begin{array}{c}\text { Extractable Fe } \\
\mu \mathrm{mol} / \mathrm{cc}\end{array}$ & $\begin{array}{r}\text { Total S } \\
\mu \mathrm{mol} / \mathrm{cc}\end{array}$ \\
\hline 15 -Aug-04 & 0.14 & 30.96 & 14.7 & 7.67 \\
\hline 15-Aug-04 & 0.06 & 38 & 6.85 & 7.46 \\
\hline 15-Aug-04 & 0.13 & 39.28 & 10.85 & 10.19 \\
\hline 8-Aug-05 & 0.43 & 17.51 & 18.91 & 2.28 \\
\hline 8-Aug-05 & 0.41 & 16.48 & 12.16 & 2.66 \\
\hline 8-Aug-05 & 0.31 & 15.65 & 7.85 & 2.63 \\
\hline 1-Aug-06 & 0.11 & 54.03 & 5.09 & 18.93 \\
\hline 1-Aug-06 & 0.10 & 66.05 & 4.89 & 13.14 \\
\hline 1-Aug-06 & 0.07 & 65.79 & 3.83 & 15.39 \\
\hline 5-Aug-07 & 0.13 & 76.33 & 1.35 & 5.94 \\
\hline 5-Aug-07 & 0.14 & 77.7 & 1.37 & 11.7 \\
\hline 5-Aug-07 & 0.17 & 72.07 & 1.85 & 11.4 \\
\hline 10-Aug-08 & 0.16 & 78.19 & 92.25 & 1.27 \\
\hline 10-Aug-08 & 0.16 & 67.68 & 65.15 & 2.99 \\
\hline 10-Aug-08 & 0.15 & 74.44 & 57.05 & 15.21 \\
\hline 10-Aug-08 & 0.13 & 75.08 & 78.44 & 2.53 \\
\hline 15-Aug-09 & 0.13 & 68.39 & 5.31 & 16.85 \\
\hline 15-Aug-09 & 0.17 & 70.07 & 6.19 & 14.86 \\
\hline 15-Aug-09 & 0.10 & 76.54 & 3.92 & 23.46 \\
\hline 15-Aug-10 & 0.10 & 83.02 & 0.05 & 7.12 \\
\hline 15-Aug-10 & 0.11 & 75.68 & 0.06 & 14.37 \\
\hline 15-Aug-10 & 0.13 & 71.26 & 0.02 & 9.21 \\
\hline
\end{tabular}


Table F 2 SRS2 soil characteristics collected during 2004 - 2010 (DBHYDRO and Florida coastal everglades long term ecological research websites)

\begin{tabular}{|c|c|c|c|c|}
\hline Date & $\underset{\mathbf{g} / \mathbf{c c}}{\boldsymbol{\rho}_{\mathbf{b}}}$ & $\begin{array}{c}\text { Organics } \\
\%\end{array}$ & $\begin{array}{c}\text { Extractable F } \\
\mu \mathrm{mol} / \mathrm{cc}\end{array}$ & $\begin{array}{c}\text { Total S } \\
\mu \mathrm{mol} / \mathrm{cc}\end{array}$ \\
\hline 15-Aug-04 & 0.11 & 40.93 & 12.28 & 3.43 \\
\hline 15-Aug-04 & 0.12 & 39.93 & 15.23 & 4.03 \\
\hline 15-Aug-04 & 0.09 & 38.67 & 9.17 & 4.14 \\
\hline 8-Aug-05 & 0.10 & 83.71 & 4.75 & 0.61 \\
\hline 8-Aug-05 & 0.10 & 89.19 & 5.87 & 0.94 \\
\hline 8-Aug-05 & 0.11 & 85.71 & 6.33 & 1.49 \\
\hline 1-Aug-06 & 0.07 & 85.85 & 2.74 & 1.03 \\
\hline 1-Aug-06 & 0.07 & 86.35 & 2.58 & 2.63 \\
\hline 1-Aug-06 & 0.06 & 83.98 & 2.38 & 2.31 \\
\hline 5-Aug-07 & 0.11 & 85.74 & 0.95 & 6.66 \\
\hline 5-Aug-07 & 0.10 & 82.65 & 1.04 & 5.29 \\
\hline 5-Aug-07 & 0.12 & 87.63 & 0.77 & 7.31 \\
\hline 10-Aug-08 & 0.07 & 89.59 & 30.62 & 4.49 \\
\hline 10 -Aug-08 & 0.11 & 86.39 & 9.64 & 5.27 \\
\hline 10-Aug-08 & 0.08 & 86.83 & 22.06 & 0.57 \\
\hline 15-Aug-09 & 0.14 & 82.46 & 4.14 & 7.84 \\
\hline 15-Aug-09 & 0.16 & 86.64 & 4.25 & 7.96 \\
\hline 15-Aug-09 & 0.15 & 82.9 & 6.28 & 10.11 \\
\hline 15-Aug-10 & 0.09 & 85 & 0 & 6.49 \\
\hline 15-Aug-10 & 0.08 & 87.3 & 0.02 & 7.76 \\
\hline
\end{tabular}


Table F 3 SRS3 soil characteristics collected during $2004-2010$ (DBHYDRO and Florida coastal everglades long term ecological research websites)

\begin{tabular}{|c|c|c|c|c|}
\hline Date & $\underset{\mathbf{g} / \mathbf{c c}}{\boldsymbol{\rho}_{\mathbf{b}}}$ & $\begin{array}{c}\text { Organic } \\
\% \mathrm{~s}\end{array}$ & $\begin{array}{c}\text { Extractable Fe } \\
\mu \mathrm{mol} / \mathrm{cc}\end{array}$ & $\begin{array}{l}\text { Total S } \\
\mu \mathrm{mol} / \mathrm{c}\end{array}$ \\
\hline 15-Aug-04 & 0.11 & 41.29 & 10.48 & 1.35 \\
\hline 15-Aug-04 & 0.11 & 41.54 & 9.17 & 1.55 \\
\hline 15-Aug-04 & 0.08 & 40.69 & 8.64 & 1.91 \\
\hline 8-Aug-05 & 0.10 & 86.48 & 5.65 & 0.67 \\
\hline 8-Aug-05 & 0.09 & 86.44 & 5.22 & 0.56 \\
\hline 8-Aug-05 & 0.07 & 87.47 & 5.14 & 1.07 \\
\hline 1-Aug-06 & 0.04 & 86.49 & 2.33 & 1.25 \\
\hline 1-Aug-06 & 0.04 & 87.87 & 1.89 & 1.28 \\
\hline 1-Aug-06 & 0.03 & 86.23 & 1.71 & 1.57 \\
\hline 5-Aug-07 & 0.09 & 87.38 & 0.77 & 1.35 \\
\hline 5-Aug-07 & 0.09 & 88.37 & 0.83 & 2.18 \\
\hline 5-Aug-07 & 0.08 & 87.09 & 0.72 & 1.39 \\
\hline 10-Aug-08 & 0.13 & 88.15 & 19.27 & 1.51 \\
\hline 10-Aug-08 & 0.14 & 87.96 & 22.71 & 1.27 \\
\hline 10 -Aug-08 & 0.10 & 88.57 & 15.15 & 1.58 \\
\hline 15-Aug-09 & 0.15 & 86.73 & 3.84 & 2.83 \\
\hline 15-Aug-09 & 0.15 & 87.32 & 3.48 & 1.22 \\
\hline 15-Aug-09 & 0.15 & 86.89 & 3.45 & 1.25 \\
\hline 15-Aug-10 & 0.10 & 88.27 & 0.02 & 0.82 \\
\hline 15-Aug-10 & 0.10 & 87.35 & 0 & 1.2 \\
\hline 15-Aug-10 & 0.08 & 88.26 & 0 & 1.75 \\
\hline
\end{tabular}


Table F 4 SRS4 soil characteristics collected during 2004 - 2010 (DBHYDRO and Florida coastal everglades long term ecological research websites)

\begin{tabular}{|c|c|c|c|c|}
\hline Date & $\underset{\mathrm{g} / \mathrm{cc}}{\boldsymbol{\rho}_{\mathrm{b}}}$ & $\begin{array}{c}\text { Organics } \\
\%\end{array}$ & $\begin{array}{c}\text { Extractable Fe } \\
\mu \mathrm{mol} / \mathrm{cc}\end{array}$ & $\begin{array}{c}\text { Total S } \\
\mu \mathrm{mol} / \mathrm{cc}\end{array}$ \\
\hline 15-Aug-04 & 0.14 & 41.49 & 4.37 & 19.3 \\
\hline 15-Aug-04 & 0.17 & 40.96 & 6.48 & 13.98 \\
\hline 15-Aug-04 & 0.14 & 40.37 & 9.64 & 4.1 \\
\hline 8-Aug-05 & 0.13 & 86.59 & 5.36 & 0.66 \\
\hline 8-Aug-05 & 0.20 & 91.48 & 10.22 & 1 \\
\hline 8-Aug-05 & 0.13 & 89.32 & 8.06 & 0.52 \\
\hline 1-Aug-06 & 0.08 & 86.74 & 1.29 & 5.53 \\
\hline 1-Aug-06 & 0.11 & 86.62 & 1.71 & 3.01 \\
\hline 1-Aug-06 & 0.08 & 87.31 & 0.93 & 7.39 \\
\hline 5-Aug-07 & 0.16 & 85.38 & 0.93 & 4.15 \\
\hline 5-Aug-07 & 0.15 & 85 & 1.05 & 5.87 \\
\hline 5-Aug-07 & 0.16 & 86.11 & 0.94 & 5.79 \\
\hline 10 -Aug-08 & 0.16 & 86.19 & 13.28 & 0.49 \\
\hline 10-Aug-08 & 0.19 & 86.49 & 25.59 & 0.32 \\
\hline 10 -Aug-08 & 0.16 & 85.38 & 24.74 & 0.31 \\
\hline 15-Aug-09 & 0.16 & 86.6 & 2.62 & 6.55 \\
\hline 15-Aug-09 & 0.26 & 48.12 & 3.2 & 7.64 \\
\hline 15-Aug-09 & 0.18 & 84.37 & 4.03 & 5.1 \\
\hline 15-Aug-10 & 0.13 & 86.29 & 0 & 3.35 \\
\hline
\end{tabular}


Table F 5 SRS5 soil characteristics collected during $2004-2010$ (DBHYDRO and Florida coastal everglades long term ecological research websites)

\begin{tabular}{|c|c|c|c|c|}
\hline Date & $\underset{\mathrm{g} / \mathrm{cc}}{\boldsymbol{\rho}_{\mathrm{b}}}$ & $\begin{array}{c}\text { Organics } \\
\%\end{array}$ & $\begin{array}{c}\text { Extractable Fe } \\
\mu \mathrm{mol} / \mathrm{cc}\end{array}$ & $\begin{array}{l}\text { Total S } \\
\mu \mathrm{mol} / \mathrm{cc}\end{array}$ \\
\hline 15-Aug-04 & 0.12 & 30.31 & 11.17 & 14.74 \\
\hline 15-Aug-04 & 0.18 & 29.21 & 11.01 & 33.13 \\
\hline 15-Aug-04 & 0.19 & 27.73 & 9.32 & 11.42 \\
\hline 8-Aug-05 & 0.17 & 79.67 & 7.19 & 8.84 \\
\hline 8-Aug-05 & 0.15 & 70.94 & 8.35 & 5.19 \\
\hline 8-Aug-05 & 0.15 & 61.47 & 9.07 & 4.41 \\
\hline 1-Aug-06 & 0.13 & 61.67 & 2.51 & 24.06 \\
\hline 1-Aug-06 & 0.27 & 24.65 & 6.33 & 5.1 \\
\hline 1-Aug-06 & 0.13 & 55.72 & 2.48 & 16.77 \\
\hline 1-Aug-06 & 0.32 & 17.75 & 5.79 & 18.32 \\
\hline 5-Aug-07 & 0.26 & 39.92 & 3.43 & 29.51 \\
\hline 5-Aug-07 & 0.22 & 43.83 & 2.58 & 19.19 \\
\hline 5-Aug-07 & 0.23 & 48.81 & 2.96 & 20.15 \\
\hline 10-Aug-08 & 0.20 & 67.63 & 17.91 & 2.18 \\
\hline 10-Aug-08 & 0.20 & 55.32 & 13.62 & 3.14 \\
\hline 10 -Aug-08 & 0.25 & 54.55 & 18.76 & 2.28 \\
\hline 15-Aug-09 & 0.26 & 41.86 & 4.59 & 13.45 \\
\hline 15-Aug-09 & 0.23 & 62.25 & 2.92 & 13.35 \\
\hline 15-Aug-09 & 0.20 & 50.1 & 4.11 & 27.79 \\
\hline
\end{tabular}


Table F 6 SRS6 soil characteristics collected during 2004 - 2010 (DBHYDRO and Florida coastal everglades long term ecological research websites)

\begin{tabular}{|c|c|c|c|c|}
\hline Date & $\begin{array}{l}\rho_{\mathrm{b}} \\
\mathrm{g} / \mathrm{cc}\end{array}$ & $\underset{\%}{\text { Organics }}$ & $\begin{array}{c}\text { Extractable Fe } \\
\mu \mathrm{mol} / \mathrm{cc}\end{array}$ & Total S \\
\hline 15-Aug-04 & 0.49 & 12.83 & 14.92 & 20.16 \\
\hline 15-Aug-04 & 0.50 & 10.74 & 17.55 & 36.76 \\
\hline 15-Aug-04 & 0.47 & 9.63 & 16.13 & 15.76 \\
\hline 8-Aug-05 & 0.21 & 60.66 & 6.16 & 2.68 \\
\hline 8-Aug-05 & 0.19 & 58.44 & 5.41 & 2.49 \\
\hline 8-Aug-05 & 0.28 & 47.73 & 11.69 & 5.02 \\
\hline 1-Aug-06 & 0.29 & 24.03 & 7.5 & 40.62 \\
\hline 1-Aug-06 & 0.51 & 9.75 & 7.47 & 27.26 \\
\hline 1-Aug-06 & 0.19 & 27.98 & 5.27 & 18.47 \\
\hline 1-Aug-06 & 0.38 & 16.08 & 7.24 & 25.01 \\
\hline 5-Aug-07 & 0.58 & 17.13 & 5.59 & 36.33 \\
\hline 5-Aug-07 & 0.54 & 17.96 & 7.39 & 26.25 \\
\hline 5-Aug-07 & 0.58 & 16.25 & 6.55 & 42.06 \\
\hline 10-Aug-08 & 0.66 & 28.5 & 27.81 & 19.8 \\
\hline 10-Aug-08 & 0.49 & 18.55 & 33.43 & 12.76 \\
\hline 10-Aug-08 & 0.51 & 23.7 & 29.94 & 15.68 \\
\hline 15-Aug-09 & 0.59 & 17.27 & 11.91 & 70.42 \\
\hline 15-Aug-09 & 0.52 & 22.11 & 7.08 & 40.88 \\
\hline 15-Aug-09 & 0.38 & 30.23 & 9.08 & 51.88 \\
\hline 15-Aug-10 & 0.56 & 16.65 & 5.92 & 20.14 \\
\hline
\end{tabular}


Table $\mathrm{F} 7 \mathrm{CaCO}_{3}$ mineral content is soils, SRS1 to SRS6, collected during 2000 - 2001 (DBHYDRO and Florida coastal everglades long term ecological research websites)

\begin{tabular}{|cccc|}
\hline Site Name & Date & Sample type & \% $\mathbf{C a C O}_{\mathbf{3}}$ \\
\hline SRS1 & 10-Jan-01 & Sediment & 62.74 \\
\hline SRS2 & 16-Nov-00 & Sediment & 29.41 \\
\hline SRS3 & 14-Nov-00 & Sediment & 32.15 \\
\hline SRS4 & 17-Nov-00 & Sediment & 27.58 \\
\hline SRS5 & 17-Nov-00 & Sediment & 55.36 \\
\hline SRS6 & 17-Nov-00 & Sediment & 68.96 \\
\hline
\end{tabular}




\section{NANTAPORN NOOSAI}

$1998-2002$

$2006-2008$

$2009-2011$

$2009-2014$

2011-Present

$2011-2013$

October, 2012

April 9-12, 2013
B.E., Civil and Environmental Engineering, Prince of Songkhla University, Songkhla, Thailand.

M.E., Energy Technology and Management, The Joint Graduate School of Energy and Environment

King Mongkut's University of Technology Thonburi, Bangkok, Thailand.

Teaching Assistant, Department of Civil and Environmental Engineering, Florida International University, Miami, FL.

Doctoral Candidate, Department of Civil and Environmental Engineering, Florida International University, Miami, FL.

Member (President) of Tau Chi Alpha (TXA) Environmental Engineering Honor Society.

Research Assistant, Applied Research Center, Florida International University, Miami, FL.

Training course "Learning ArcGIS Desktop (for ArcGIS 10)", ESRI Training.

Attended "Umtra Regulations and Implementation Workshop", Office of Legacy Management, Department of Energy, Grand Junction, CO.

Storm water, Erosion, and Sedimentation Control Inspector Training, Boca Raton, FL.

\section{PUBLICATIONS AND PRESENTATIONS}

Bostick, K., Tachiev, G., Daniel, A., Pill, K., Noosai, N., Villamizar V. (2013) "LongTerm Performance of Uranium Tailings Disposal Cells," WM2013 Symposia, Paper No. 13340, 15p., February 24-28, Phoenix, Arizona, USA. 
Fuentes, H.R., and Noosai, N. (2012) "Research Efforts to Improve Hydro-geochemical Modeling of the Fate and Transport of Mercury in Surface and Ground Water Environments," Distinguished Lecture, Santander Industrial University, July 25, Colombia.

Noosai, N., and Fuentes, H.R. (2013) "Coupling and Testing the Fate and Transport of Heavy Metals and Other Ionic Species in a Groundwater Setting at Oak Ridge, TN," WM2013 Symposia, Paper No. 13498, 10p., February 24-28, Phoenix, Arizona, USA.

Noosai, N., and Fuentes, H.R. (2012) "A Geochemical Modeling Application to Assess Impact of Saline Intrusion on the Fact of Mercury $(\mathrm{Hg})$ in Florida Aquifers," Sea Level Rise Summit, June 20-22, Boca Raton, FL.

Noosai, N., Kengskool, K., and Pipatmanomai, S. (2012) "The Conversion of Biomass To Liquid Fuel: Switchgrass Pyrolysis Process," Mid-South Annual Engineering and Sciences Conference, May 1, Memphis, Tennessee, USA.

Noosai, N., Kengskool, K., and Pipatmanomai, S. (2011) "The Comparison of The Efficiency And Emission Of Conventional And Oxy-Fuel Combustion Process of 300 Mw Mae Moh Power Plant Using Aspen Plus Simulation," Mid-South Annual Engineering and Sciences Conference, May 3, Memphis, Tennessee, USA.

Vijayan, V., and Noosai, N. (2012) "The Study of Geochemical Processes of Selected Technologies For Acid Mine Drainage Treatments," Mid-South Annual Engineering and Sciences Conference, May 1, Memphis, Tennessee, USA.

Noosai, N., and Fuentes, H.R. (20xx) "Geochemical tool: An Application To Assess The Impact Of Seawater Intrusion On Floridian Aquifer Groundwater," Applied Geochemistry, (in process). 